\title{
Geologic Setting and Water Quality of Selected Basins in the Active Coal-Mining Areas of Ohio, 1989-91, with a Summary of Water Quality for 1985-91
}

By Alan C. Sedam and Donna S. Francy

United States Geological Survey

Water-Resources Investigations Report 93-4094

Prepared in cooperation with the Ohio Department of Natural Resources, Division of Reclamation

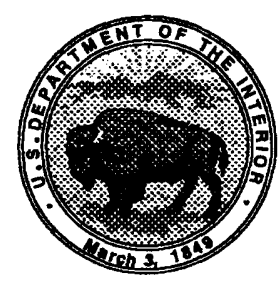




\section{U.S. DEPARTMENT OF THE INTERIOR BRUCE BABBITT, Secretary}

\section{U.S. GEOLOGICAL SURVEY}

Robert M. Hirsch, Acting Director

Any use of trade names in this publication is for descriptive purposes only and does not imply endorsement by the U.S. Geological Survey.

UNITED STATES GOVERNMENT PRINTING OFFICE: 1993

Copies of this report may be purchased from:

U.S. Geological Survey

Earth Science Information Center

Open-File Reports Section

Box 25286, MS 517

Denver Federal Center

Denver, CO 80225

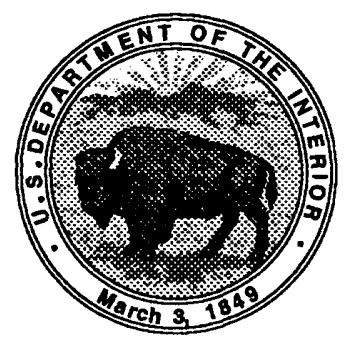

Lubrary of Congress Cataloging in Publication Data 


\section{CONTENTS}

Abstract--- ----1

Introduction--.--..- 2

Purpose and scope - -

Description of study area -

Acknowledgments --_- 14

Methods of study -

Water quality of the study area, 1989-91

Streamwater at long-term sites, 1989-91 -ב-_-- 16

Ground water --

Geologic setting and water quality of selected basins -- 26

Conotton Creek basin--

Geologic setting --

. Water quality - $\quad 28$

Streamwater --_-

Ground water--_- 29

Lower Wills Creek basin

Geologic setting --_- 35

Water quality--..- 35

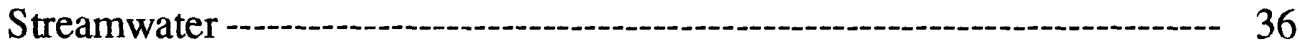

Ground water -

Upper Hocking River basin-_-_-_- 37

Geologic setting --_o-_- 37

Water quality --o 43

Streamwater -

Ground water --

Yellow and Cross Creeks basin -.....- 49

Geologic setting -._- 49

Water quality --

Walhonding River basin--

Geologic setting - -

Water quality -

Streamwater -..- 58

Ground water-1- 58

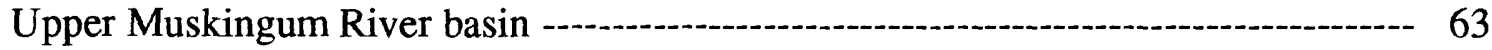

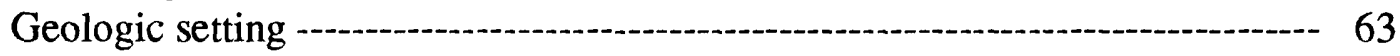

Water quality-

Streamwater -..--_-_-- 66

Ground water-1-_- 66 


\section{CONTENTS-Continued}

Middle Muskingum River basin--

Geologic setting -

Water quality---_- 73

Streamwater -- 74

Ground water-- 74

Middle Hocking River basin --_- 79

Geologic setting -- 79

Water quality---or 81

Streamwater -

Ground water--

Leading Creek basin -

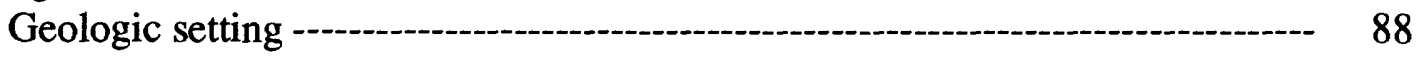

Water quality-- 88

Lower Raccoon Creek basin--

Geologic setting -

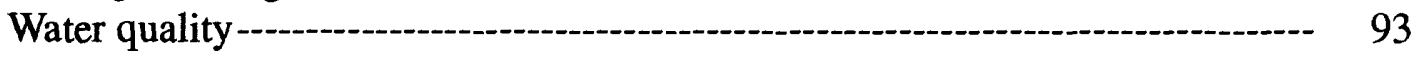

Summary of water quality for 1985-91 - 93

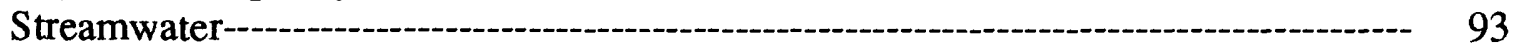

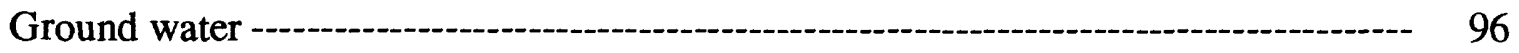

Summary and conclusions----_on 100

References cited-- 102

FIGURES

1. Map showing locations of study basins -

2. Map showing land use in eastern Ohio -

3. Map showing generalized geology of study area--

4. Generalized geologic column for southeastern Ohio, including relative position of important coal beds --

5. Map showing principal aquifers in Ohio -...- 11

6. Map showing locations of long-term streamwater sites---on

7. Box plots showing the ranges, percentiles, and medians of constituents in 246 samples collected at 41 long-term streamwater sites in active coalmining areas of Ohio, 1989-91-

8. Map showing locations of ground-water sampling sites, 1989-91-_- 22

9. Piper diagram showing distribution of constituents for ground-water sites sampled in active coal-mining areas of Ohio, 1989-91-_. 25

10. Map showing Conotton Creek basin (F), streamwater sites, ground-water sites, and Stiff diagrams for ground-water sites

11. Box plots showing the ranges, percentiles, and medians of constituents at six streamwater sites in the Conotton Creek basin

12. Map showing Lower Wills Creek basin (L), streamwater sites, ground-water sites, and Stiff diagrams for ground-water sites 
13. Box plots showing the ranges, percentiles, and medians of constituents at seven streamwater sites in the Lower Wills Creek basin ---

14. Map showing Upper Hocking River basin (P), streamwater sites, ground-water sites, and Stiff diagrams for ground-water sites---on

15. Box plots showing the ranges, percentiles, and medians of constituents at seven streamwater sites in the Upper Hocking River basin---

16. Map showing Yellow and Cross Creeks basin (B) and streamwater sites------------ $\quad 50$

17. Box plots showing the ranges, percentiles, and medians of constituents at eight streamwater sites in the Yellow and Cross Creeks basin--

18. Map showing Walhonding River basin (J), streamwater sites, ground-water sites, and Stiff diagrams for ground-water sites---

19. Box plots showing the ranges, percentiles, and medians of constituents at seven streamwater sites in the Walhonding River basin

20. Map showing Upper Muskingum River basin (M), streamwater sites, groundwater sites, and Stiff diagrams for ground-water sites

21. Box plots showing the ranges, percentiles, and medians of constituents at seven streamwater sites in the Upper Muskingum River basin -

22. Map showing Middle Muskingum River basin $(\mathrm{N})$, streamwater sites, ground-water sites, and Stiff diagrams for ground-water sites-

23. Box plots showing the ranges, percentiles, and medians of constituents at eight streamwater sites in the Middle Muskingum River basin

24. Map showing Middle Hocking River basin (Q), streamwater sites, ground-water sites, and Stiff diagrams for ground-water sites-

25. Box plots showing the ranges, percentiles, and medians of constituents at eight streamwater sites in the Middle Hocking River basin-------

26. Map showing Leading Creek basin (QQ) and streamwater sites -

27. Map showing Lower Raccoon Creek basin (S) and streamwater sites --.------

28. Box plots showing the ranges, percentiles, and medians of constituents in 508 samples collected at 41 long-term streamwater sites in active coal-mining areas of Ohio, 1985-91

29. Piper diagram showing distribution of constituents for ground-water sites sampled in active coal-mining areas of Ohio, 1985-91

\section{TABLES}

1. Study basins and assigned identifiers

2. Ranges and medians for selected water-quality characteristics for long-term streamwater sites in active coal-mining areas of Ohio, 1989-91

3. Ranges and medians for selected water-quality characteristics for ground-water sites in active coal-mining areas of Ohio, 1989-91 -

4. Water-quality data for streamwater sites in Conotton Creek basin, October 1989----- 30 


\section{TABLES-Continued}

5. Ranges and medians for selected water-quality characteristics for streamwater sites in Conotton Creek basin, October 1989-

6. Water-quality data for ground-water sites in Conotton Creek basin, September 1989

7. Water-quality data for streamwater sites in Lower Wills Creek basin, October 1989

8. Ranges and medians for selected water-quality characteristics for streamwater sites in Lower Wills Creek basin, October 1989-

9. Water-quality data for ground-water sites in Lower Wills Creek basin, September 1989

10. Water-quality data for streamwater sites in Upper Hocking River basin, October 1989

11. Ranges and medians for selected water-quality characteristics for streamwater sites in Upper Hocking River basin, October 1989

12. Water-quality data for ground-water sites in Upper Hocking River basin, August-September 1989

13. Water-quality data for streamwater sites in Yellow and Cross Creeks basin, June 1991

14. Ranges and medians for selected water-quality characteristics for streamwater sites in Yellow and Cross Creeks basin, June 1991

15. Water-quality data for streamwater sites in Walhonding River basin, June 1991 -----

16. Ranges and medians for selected water-quality characteristics for streamwater sites in Walhonding River basin, June 1991

17. Water-quality data for ground-water sites in Walhonding River basin, August 1990

18. Water-quality data for streamwater sites in Upper Muskingum River basin, June 1991

19. Ranges and medians for selected water-quality characteristics for streamwater sites in Upper Muskingum River basin, June 1991

20. Water-quality data for ground-water sites in Upper Muskingum River basin, August 1990

21. Water-quality data for streamwater sites in Middle Muskingum River basin, October 1991

22. Ranges and medians for selected water-quality characteristics for streamwater sites in Middle Muskingum River basin, October 1991 -

23. Water-quality data for ground-water sites in Middle Muskingum River basin, September 1991

24. Water-quality data for streamwater sites in Middle Hocking River basin, October-November 1991

25. Ranges and medians for selected water-quality characteristics for streamwater sites in Middle Hocking River basin, October-November 1991

26. Water-quality data for ground-water sites in Middle Hocking River basin, September 1991 
27. Water-quality data for streamwater sites in Leading Creek basin, October-November 1991 -

28. Ranges and medians for selected water-quality characteristics for streamwater sites in Leading Creek basin, October-November 1991

29. Ranges and medians for selected water-quality characteristics for long-term streamwater sites in active coal-mining areas of Ohio, 1985-91

30. Ranges and medians for selected water-quality characteristics for ground-water sites sampled in active coal-mining areas of Ohio, 1985-91 - 99

31. Water-quality data for long-term streamwater sites, 1989-91 - 


\begin{tabular}{|c|c|c|}
\hline Multiply & By & To obtaln \\
\hline $\begin{array}{r}\text { inch (in.) } \\
\text { foot (ft) } \\
\text { mile (mi) } \\
\text { acre }\end{array}$ & $\begin{array}{l}25.4 \\
0.3048 \\
1.609 \\
0.4047\end{array}$ & $\begin{array}{l}\text { millimeter } \\
\text { meter } \\
\text { kilometer } \\
\text { hectare }\end{array}$ \\
\hline $\begin{array}{r}\text { square mile }\left(\mathrm{mi}^{2}\right) \\
\text { foot per mile }(\mathrm{ft} / \mathrm{mi})\end{array}$ & $\begin{array}{l}2.590 \\
0.1894\end{array}$ & $\begin{array}{l}\text { square kilometer } \\
\text { meter per kilometer }\end{array}$ \\
\hline $\begin{array}{r}\text { cubic foot per second }\left(\mathrm{ft}^{3} / \mathrm{s}\right) \\
\text { gallon per minute }(\mathrm{gal} / \mathrm{min}) \\
\text { ton }(\mathrm{short})\end{array}$ & $\begin{array}{l}0.02832 \\
0.06309 \\
0.90718\end{array}$ & $\begin{array}{l}\text { cubic meter per second } \\
\text { liter per second } \\
\text { metric tons }\end{array}$ \\
\hline
\end{tabular}

Chemical concentrations and water temperature are given in metric units. Chemical concentration is given in milligrams per liter $(\mathrm{mg} / \mathrm{L})$ or micrograms per liter $(\mu \mathrm{g} / \mathrm{L})$. Milligrams per liter is a unit expressing the concentration of chemical constituents in solution as weight (milligrams) of solute per unit volume (liter) of water. One thousand micrograms per liter is equivalent to one milligram per liter. For concentrations less than $7,000 \mathrm{mg} / \mathrm{L}$, the numerical value is the same as for concentraions in parts per million.

Temperature is given in degrees Celsius $\left({ }^{\circ} \mathrm{C}\right)$, which can be converted to degrees Fahrenheit $\left({ }^{\circ} \mathrm{F}\right)$ by the following equation:

$$
\mathrm{F}=1.8\left({ }^{\circ} \mathrm{C}\right)+32
$$

Sea level: In this report "sea level" refers to the National Geodetic Vertical Datum of 1929 (NGVD of 1929)—a geodetic datum derived from a general adjustment of the first-order level nets of both the United States and Canada, formerly called Sea Level Datum of 1929. 


\section{IDENTIFICATION OF SAMPLE-COLLECTION SITE}

In water-quality data tables, collection sites are identified as follows:

$\begin{array}{cccccc}\begin{array}{c}\text { Surface- } \\ \text { water } \\ \text { site }\end{array} & \begin{array}{l}\text { Station } \\ \text { number }\end{array} & \begin{array}{c}\text { Basin } \\ \text { code }\end{array} & \text { Station name } & \text { Latitude } & \text { Longitude } \\ & 03116950 & \text { G-2 } & \begin{array}{c}\text { NEWMAN C NR } \\ \text { MASSILLON OH }\end{array} & \text { (LAT 40 49 22N } & \text { LONG 081 33 06W) }\end{array}$

$\begin{array}{lccccc}\begin{array}{l}\text { Ground- } \\ \text { water } \\ \text { site }\end{array} & \begin{array}{c}\text { Station } \\ \text { number }\end{array} & \begin{array}{c}\text { Local } \\ \text { number }\end{array} & \begin{array}{c}\text { Owner and } \\ \text { location }\end{array} & \text { Latitude } & \text { Longitude } \\ & 403830081220700 & \text { TU-53 } & \begin{array}{c}\text { US POST OFFICE AT } \\ \text { SANDYVILLE OH }\end{array} & \text { (LAT 40 38 30N } & \text { LONG 081 22 07W) }\end{array}$

\section{STANDARD ABBREVIATIONS USED IN STATION NAMES}

$\begin{array}{lllllll}\text { AB Above } & \text { C Creek } & \text { L Little } & \text { NR Near } & \text { TR Tributary } \\ \text { B Branch } & \text { E East } & \text { LK Lake } & \text { R River } & \text { W West } \\ \text { BK } \text { Brook } & \text { F Fork } & \text { M Middle } & \text { RN Run } & & \\ \text { BL Below } & \text { G Great } & \text { N North } & \text { S South } & \end{array}$





\title{
Geologic Setting and Water Quality of Selected Basins in the Active Coal-Mining Areas of Ohio, 1989-91, with a Summary of Water Quality for $1985-91$
}

\author{
By Alan C. Sedam and Donna S. Francy
}

\section{ABSTRACT}

This report presents streamwater- and ground-water-quality data collected to characterize the baseline water quality for 21 drainage basins in the coal-mining region of eastern Ohio. The study area is mostly within the unglaciated part of eastern Ohio along the western edge of the Appalachian Plateaus Physiographic Province. The data collected from 1989-91 and presented in this report represent the third and final phase of a 7-year study to assess baseline water quality in Ohio's coal region during 1985-91.

During 1989-91, 246 samples from 41 streamwater sites were collected periodically from a long-term site network. Ranges and medians of measurements made at the long-term streamwater sites were the following: specific conductance, 270 to 5,170 and 792 microsiemens per centimeter at 25 degrees Celsius; $\mathrm{pH}, 2.7$ to 9.1 and 7.8; and alkalinity, 1 to 391 and $116 \mathrm{mg} / \mathrm{L}$ (milligrams per liter). Ranges and medians of laboratory analyses of the same samples were the following: dissolved sulfate, 13 to 2,100 and $200 \mathrm{mg} / \mathrm{L}$; dissolved aluminum, $<10$ to 17,000 and $300 \mu \mathrm{g} / \mathrm{L}$ (micrograms per liter); dissolved iron, $<10$ to 53,000 and $60 \mu \mathrm{g} / \mathrm{L}$; and dissolved manganese, $<10$ to 17,000 and $295 \mu \mathrm{g} / \mathrm{L}$. The ranges for concentrations of total recoverable aluminum, iron, and manganese were similar to the ranges of concentrations found for dissolved constituents. Medians of total recoverable aluminum and iron were about 10 times greater than the medians of dissolved aluminum and iron.
During 1989-91, once-only sample collections were done at 45 streamwater sites in nine basins chosen for synoptic sampling. At several sites in the Middle Hocking River basin and Leading Creek basin, water had low $\mathrm{pH}$ and high concentrations of dissolved sulfate and total recoverable and dissolved aluminum, iron, and manganese. These water- . quality characteristics are commonly associated with acid mine drainage.

Throughout the entire 7-year study (198591), medians for most constituents at the longterm streamwater-sampling sites were fairly consistent, despite the geographic diversity of the study area. Waters from several long-term sites, including several sites in the Moxahala Creek and Middle Hocking River basins, had low $\mathrm{pH}$ and high concentrations of several constituents, including dissolved sulfate, iron, aluminum, and manganese; this combination of characteristics is indicative of acid drainage from surface-mining operations. At many of the streamwater sites where concentrations of these constituents were high, $\mathrm{pH}$ values in the neutral or alkaline range were indicative of stream buffering by carbonate rock or restoration of mined lands in the drainage system. The basins with sites in this category include Yellow and Cross Creeks and Wheeling Creek basins. Water quality at other sites showed little or no effects from surface mining.

Ground-water samples collected during the last phase of the study (1989-91) were mostly from unconsolidated aquifers. The waters were generally hard to very hard and calcium 
bicarbonate in type. During the entire 7-year study period, medians of $\mathrm{pH}$ in ground-water samples varied little, and most values were in the alkaline range. Except for a few sites where concentrations of dissolved sulfate exceeded $250 \mathrm{mg} / \mathrm{L}$ and concentrations of total recoverable and dissolved iron and manganese exceeded $1,000 \mu \mathrm{g} / \mathrm{L}$, the quality of ground water at the wells sampled in the study area showed little effect from coal mining.

\section{INTRODUCTION}

Coal is Ohio's most important mineral resource. At present, coal production is nearly a $\$ 1$ billion industry. In 1989 , the value of coal was about equal to that of all of the other mineral commodities in Ohio, including oil and gas (Lopez, 1991, p. 9).

Ohio coal production, which was nearly 48 million tons in 1918, generally declined after World War I until the 1940's, when production increased to fulfill the needs of World War II. The greatest production was 55 million tons in 1970. In 1989, Ohio coal production was 31.4 million tons, about 57 percent of the 1970 peak. According to Carlton (1991), much of the decline can be attributed to environmental constraints imposed by Federal legislation on the coal industry in 1970, 1979, and 1990 to improve air quality and to the relatively high sulfur content of Ohio coals.

Surface mining, which began in Ohio just before World War I, grew rapidly after World War II, and, in 1989, accounted for 65.5 percent of coal mined in the State. Except for some efforts in the 1930's to seal off underground mines, which produced acid drainage (Federal Water Pollution Control Administration, 1968), little environmental control was placed on coal-mining practices until 1948, when the State's first surface-mining law was passed. Overall, the law was ineffective because many mine operators found it cheaper to forfeit their reclamation bonds than to do postmining restoration; the result was a sub- stantial increase in abandoned surface-mined lands. This situation prompted enactment in 1972 of the Nation's most comprehensive (at the time) surface-mine reclamation law, which required "... extensive preplanning of mining and subsequent reclamation, and compliance with mining rules and regulations to insure restoration of areas affected by strip mining" (Ohio Board on Unreclaimed Strip Mined Lands, 1974, p. 2). The Ohio law was modified to conform to the U.S. Surface Mining Control and Reclamation Act of 1977 (Public Law 95-87), which provides for money collected from Federal fees on surface-mined coal to be used by the State in reclamation of abandoned surface-mined lands (U.S. Department of the Interior, 1979).

The Ohio Department of Natural Resources (ODNR), Division of Reclamation, is responsible for issuing coal-mining permits and enforcing regulations regarding restoration and reclamation of mined lands. When the 1972 law was enacted, the Board on Unreclaimed Strip Mined Lands was set up to assess the State's abandoned surface-mined lands and to make recommendations for remediation of these properties (Ohio Board on Unreclaimed Strip Mined Lands, 1974). Various studies have been done by Federal and State agencies during the past two decades. The Division of Reclamation found that systematic compilation of baseline hydrologic data was needed to facilitate the agencies' processing of coal-mining permits in unmined areas and in areas of active mining. In addition, long-term collection of these baseline data could help in the assessment of cumulative hydrologic effects of coal mining over the years on surface-water and ground-water systems throughout eastern Ohio.

In 1984, preliminary discussions between the U.S. Geological Survey (USGS) and the ODNR, Division of Reclamation, led to development of a 7-year cooperative study that began in 1985 with the establishment of a long-term surface-water site network for 
assessment of baseline water quality. The network was periodically sampled from

September 1985 through November 1991. For the purpose of this investigation, "baseline data" refers to water-quality data that are collected to describe a hydrologic system at a particular point in time. Periodic collections of such data serve as a base to which future data gathered for a particular area can be compared. The long-term sampling was supplemented by synoptic short-term data collections from surface- and ground-water sites in basins (usually three each year) selected for intensive study.

With this report, results of the 7-year study are complete. Previous reports presented data collected from 1985 through 1986 (Jones, 1988) and data collected from 1987 through 1988 (Sedam, 1991), along with descriptions of geologic settings. This report presents data collected from 1989 through 1991 and includes a discussion of water quality for the entire study period (1985-91).

\section{Purpose and Scope}

This report presents streamwater- and ground-water-quality data collected to characterize the baseline water quality of 21 drainage basins in the coal-mining region of eastern Ohio. To determine the baseline water quality from 1989 through 1991, investigators

(1) collected streamwater-quality data 6 times at 41 long-term sites ${ }^{1}$ in the 21 basins, and (2) selected 10 basins for a synoptic data collection, in which water-quality samples were collected at 45 streamwater sites in 9 basins and 28 ground-water sites in 7 basins.

\footnotetext{
1 In this report, "site" refers to a fixed site or position along a stream, or a water well where water samples are collected for chemical analysis.
}

Included in the report are descriptions of the geologic and hydrologic settings of the 10 drainage basins selected for the synoptic data collection.

This report also presents a discussion of water-quality data collected during the entire study period (1985-91). Included is a summary of streamwater-quality data ( 508 samples collected from the 41-site long-term network in 21 basins) and of ground-water-quality data (69 samples collected in 16 basins).

\section{Description of Study Area}

The study area includes all or part of 29 counties in the coal-mining region of eastern Ohio (fig. 1). The 21 drainage basins that make up the study area include the areas of the most intensive surface and subsurface mining activities in the State. The 10 basins are listed in table 1 and are shown by their respective basin identifiers (A, B, and so forth) in figure 1. The basin designations follow the usage of the ODNR. The 10 basins selected for the 1989-91 synoptic data collection were Conotton Creek (basin F), Lower Wills Creek (basin L), Upper Hocking River (basin P), Yellow and Cross Creeks (basin B), Walhonding River (basin J), Upper Muskingum River (basin M), Middle Muskingum River (basin N), Middle Hocking River (basin Q), Leading Creek (basin QQ), and Lower Raccoon Creek (basin S).

The boundary between Pleistocene glaciation on the northwest and the unglaciated terrain on the southeast is shown in figure 1. Most of the study area lies in the unglaciated Allegheny Plateau Section of the Appalachian Plateaus Physiographic Province (Fenneman, 1938, p. 283). The Ohio Department of Natural Resources, Division of Geological Survey, designates the region "Glaciated Plateau" and "Unglaciated Plateau." Local relief is from 100 to $200 \mathrm{ft}$ along the glaciated 


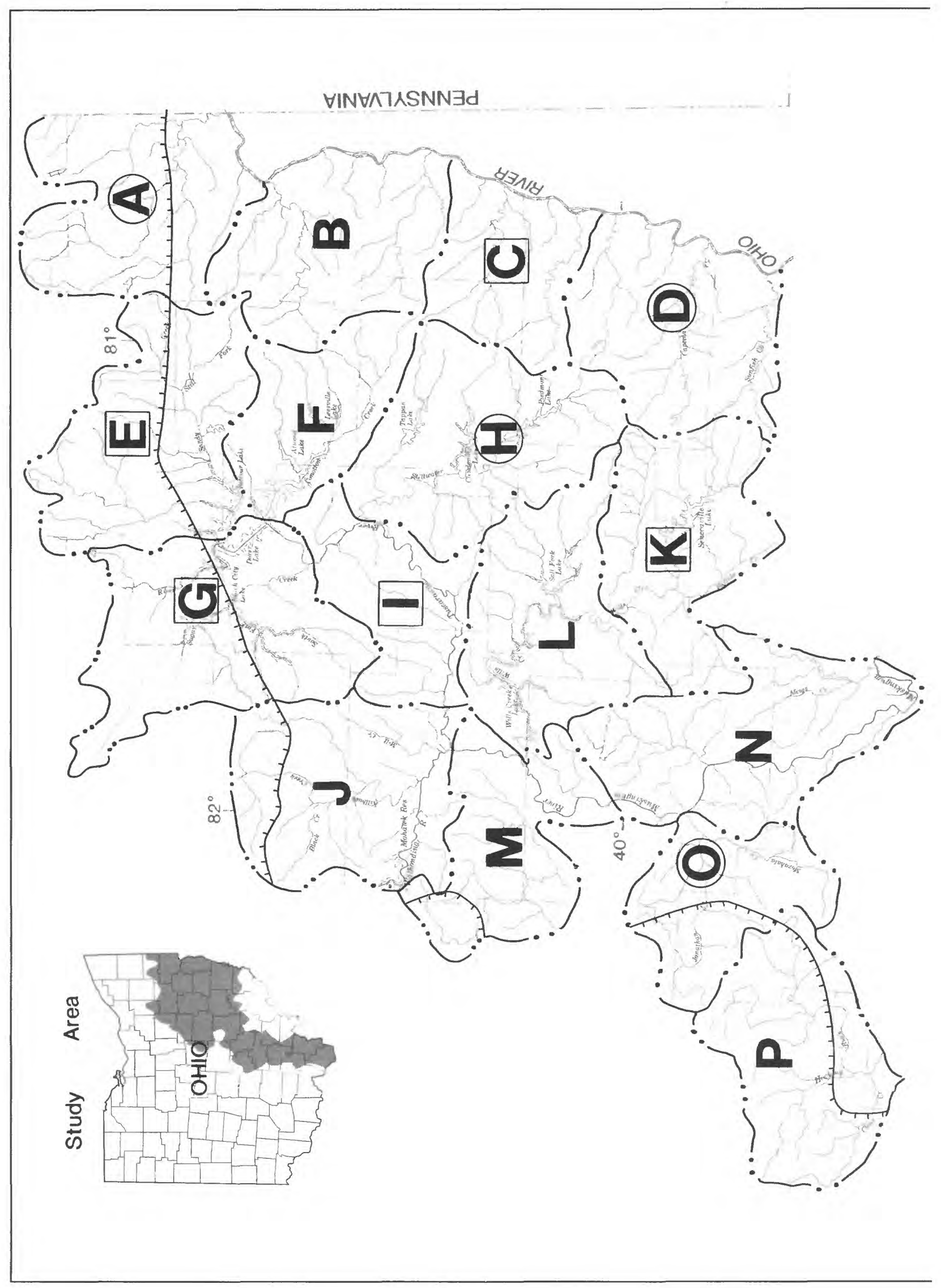




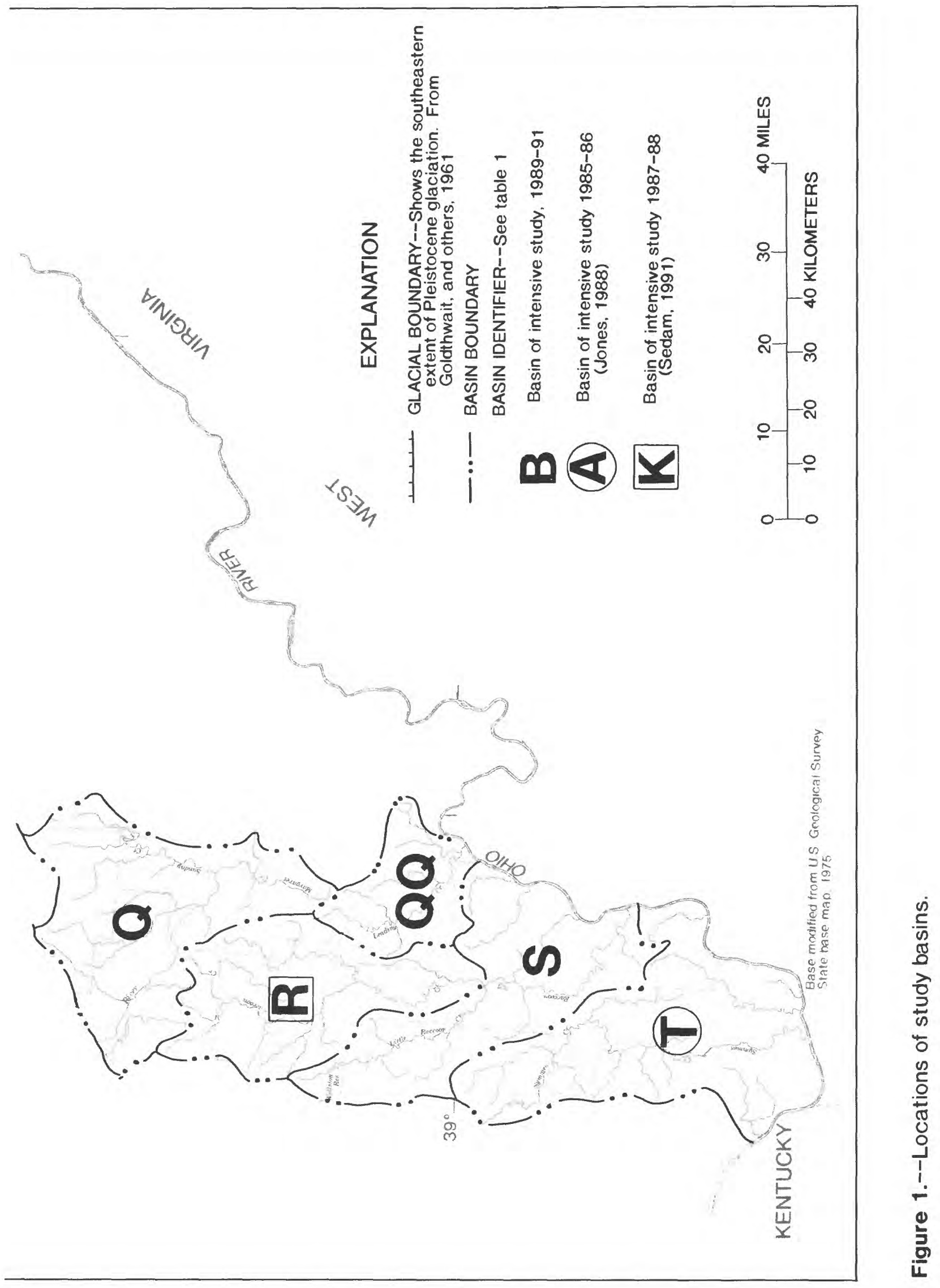


Table 1. Study basins and assigned identifiers

\section{Basin identifier}

(fig. 1)

\section{Basin name}

\begin{tabular}{ll} 
A & Little Beaver Creek \\
B & Yellow and Cross Creeks \\
C & Short and Wheeling Creeks \\
D & McMahon, Captina, and Sunfish Creeks \\
E & Sandy Creek \\
F & Conotton Creek \\
G & Middle Tuscarawas River and Sugar Creek \\
H & Stillwater Creek \\
I & Lower Tuscarawas River \\
J & Walhonding River \\
K & Upper Wills Creek \\
L & Lower Wills Creek \\
M & Upper Muskingum River \\
N & Middle Muskingum River \\
O & Moxahala Creek \\
P & Upper Hocking River \\
Q & Middle Hocking River \\
QQ & Leading Creek \\
R & Upper Raccoon Creek \\
S & Symmer Raccoon Creek \\
T & Ice, and Indian Guyan Creeks \\
\hline &
\end{tabular}


western and northern fringes of the study area but is as much as $500 \mathrm{ft}$ in places near the Ohio River Valley. In places, the land surface is flat, such as along the major streams and small areas of the upland surface.

Four generalized land-use categories in eastern Ohio are shown in figure 2 . The study area is mostly composed of an uneven distribution of forest and cropland or pasture. The largest urban area (fig. 2) is around the city of Canton in the north. Most of the areas depicted as "mining" within the study area represent surface mining of coal, although sand, gravel, and rock are extracted in some locations.

The bedrock of southeastern Ohio is a sedimentary sequence that consists mainly of shales, sandstones, and limestone ranging from Mississippian to Permian in age. The study area is underlain mostly by a complex repetitive succession of shales, sandstones, limestones, coals, and clays of Pennsylvanian age. The older rocks crop out to the west except where covered by glacial drift, and the younger rocks crop out to the east. The outcrop pattern in the study area trends northnortheast (fig. 3). Regional dip of the rocks is to the southeast, about $30 \mathrm{ft} / \mathrm{mi}$, toward the Appalachian Basin and is modified locally by several low structural features (Lamborn, 1951, p. 13). The lithology and stratigraphic position of the Pennsylvanian formations is shown in figure 4. The designation of the Pottsville, Allegheny, Conemaugh, and Monongahela as "Formations" follows the usage of the USGS. In Ohio, these formations are generally classified as "groups." Collins' review of Ohio geology (1979) explains the criteria used to classify the Mississippian, Pennsylvanian, and Permian Systems in Ohio.

On the basis of formation thickness, Stout and others (1943) noted that the Pottsville contains 42 percent sandstone; the Allegheny, 40 percent; the Conemaugh, less than 30 percent; and the Monongahela, only about 15 percent. Conversely, the carbonate content increases from older to younger Pennsylvanian rocks; therefore, the Monongahela Formation contains more carbonate than the Allegheny Formation. Based on studies such as Lamborn's (1951, p. 22-26), rocks of the Lower ennsylvanian in Ohio, except for the coals, are largely of marine origin but are nonmarine in the Upper Pennsylvanian. The zone of transition extends from about the middle of the Allegheny into the Conemaugh Formation (Razem and Sedam, 1985, p. 9)

Some 24 beds of mineable coal (thickness, 14 in. or more) in 32 counties made up an original reserve of 46 billion tons of coal in Ohio (Brant and Delong, 1960, p. 3). Most of the coal mined is from the Allegheny and Monongahela Formations. The coals listed in figure 4 make up about 92 percent of the State's original reserves. On the basis of 1989 data, the five leading producers, in order, were the Pittsburgh (No. 8), Meigs Creek (No. 9), Clarion (No. 4A), Middle Kittanning (No. 6), and Lower Kittanning (No. 5) coals, which amounted to about 80 percent of the State's total coal production (Lopez, 1991).

The location of the study area in relation to the principal aquifers in Ohio is shown in figure 5. Much of the northwestern half of the study area is underlain by strata categorized as sandstone aquifers (fig. 5). This area generally coincides with outcrop areas of the Pottsville and Allegheny Formations. Ground-waterresource maps published by ODNR show possible well yields ranging from 5 to $25 \mathrm{gal} / \mathrm{min}$ for this area. In general, the various sandstone members in the lower part of the Pennsylvanian system are the aquifers. Similar maps for the rest of the study area show that well yields are from 0 to $5 \mathrm{gal} / \mathrm{min}$, which are typical of the shaly sandstone and carbonate rocks that underlie the area (fig. 5). The area corresponds approximately to the outcrop area of the Conemaugh and Monongahela Formations. 


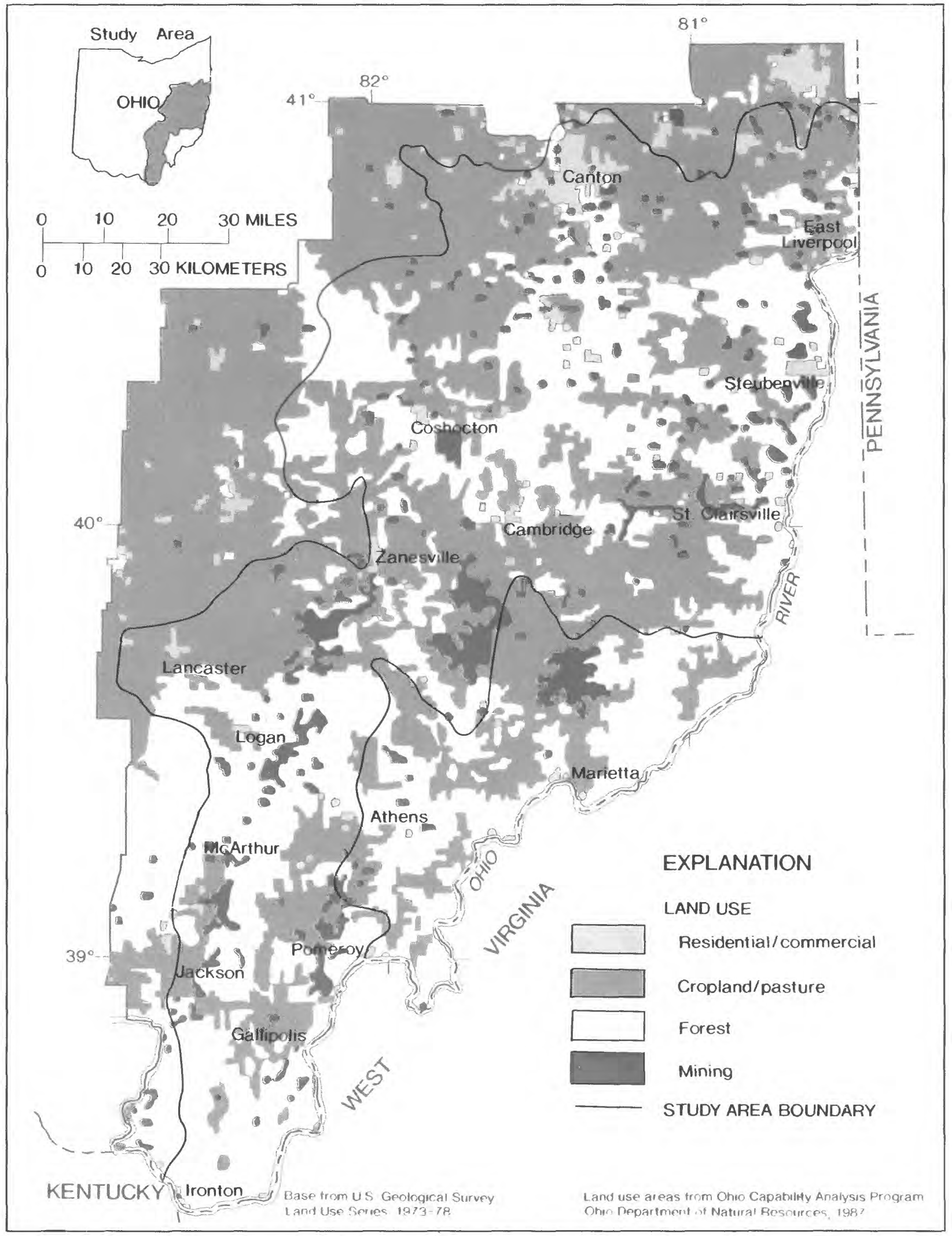

Figure 2.--Land use in eastern Ohio. 


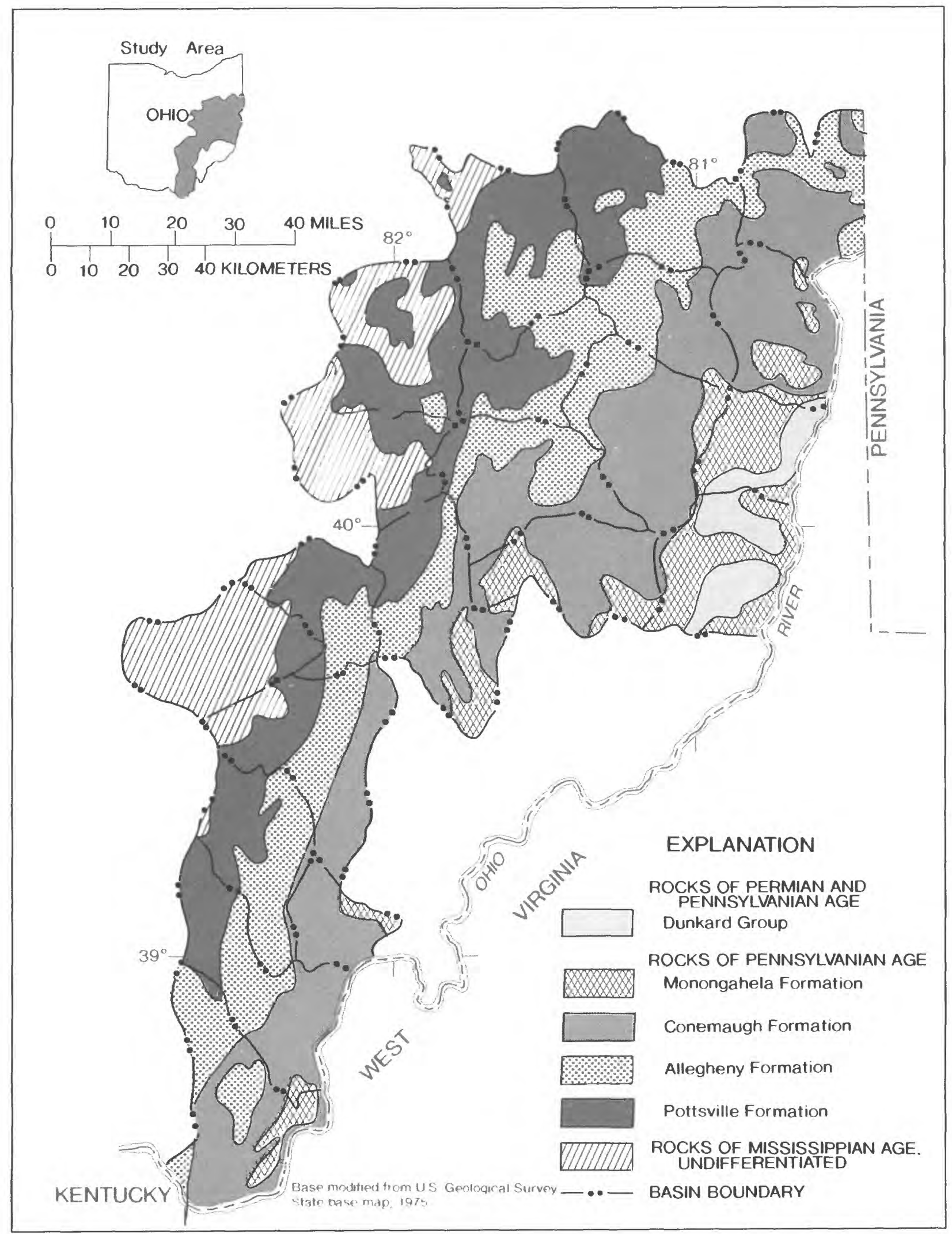

Figure 3.--Generalized geology of study area. (Modified from Collins, 1979, fig. 1.) 


\begin{tabular}{|c|c|c|c|}
\hline System & \begin{tabular}{|l|} 
Group, \\
Formation
\end{tabular} & Description & Important coal beds \\
\hline 蛋 & 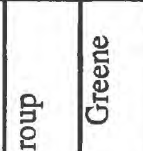 & $\begin{array}{l}\text { Mostly red shales and limestones, localized coals, and sandstone bodies. Areas } \\
\text { of occurrence are small. }\end{array}$ & No. 12 Washington \\
\hline 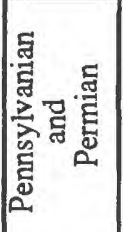 & 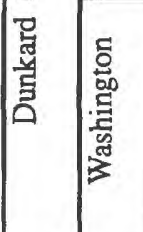 & $\begin{array}{l}\text { Sandstones, shales, and minor coals. Sandstones are typically micaceous, fine to } \\
\text { medium grained, and have thin conglomeratic zones. Locally, sandstones may } \\
\text { be massively developed. }\end{array}$ & \\
\hline \multirow{5}{*}{ 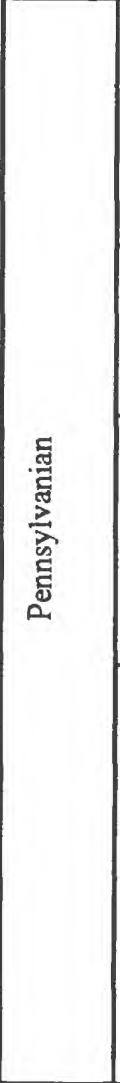 } & 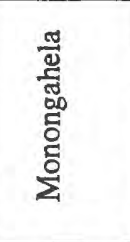 & $\begin{array}{l}\text { Important coal-bearing strata and associated beds of clay, shale, sandstone, and } \\
\text { limestone. Sandstones tend to be fine to medium grained, micaceous, and } \\
\text { patchy in development. Compared to other Pennsylvanian units, the } \\
\text { Monongahela has a smaller proportion of sandstone and a larger proportion of } \\
\text { limestone. Limestones tend to be marly, freshwater types. Secondary porosity } \\
\text { along fractured surfaces is well developed locally. }\end{array}$ & $\begin{array}{l}\text { No. } 11 \text { Waynesburg } \\
\text { No. } 10 \text { Uniontown } \\
\text { No. } 9 \text { Meigs Creek } \\
\text { No. } 8 \text { Pittsburgh }\end{array}$ \\
\hline & 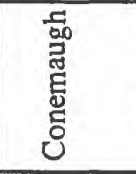 & $\begin{array}{l}\text { Thick repetitious succession of shales and patchy sandstones interspersed with } \\
\text { thin, discontinuous coals and clays and widespread limestones. The lower lime- } \\
\text { stones are of marine origin, whereas those in the upper part are marly, fresh- } \\
\text { water types. Secondary porosity along fractured surfaces is common. }\end{array}$ & \\
\hline & 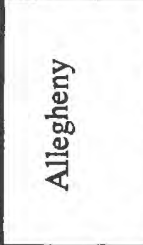 & $\begin{array}{l}\text { Repetitious succession of important coal-bearing strata interspersed with sev- } \\
\text { eral fine- to coarse-grained, massive, cross-bedded sandstones and thin, persis- } \\
\text { tent limestones. Sandstones, though widespread, have considerable local lateral } \\
\text { variation. Solution cavities are developed locally in the limestones. }\end{array}$ & $\begin{array}{l}\text { No. } 7 \text { Upper Freeport } \\
\text { No. 6A Lower Freeport } \\
\text { No. } 6 \text { Middle Kittanning } \\
\text { No. } 5 \text { Lower Kittanning } \\
\text { No. 4A Clarion } \\
\text { No. } 4 \text { Brookville }\end{array}$ \\
\hline & \multirow{2}{*}{ 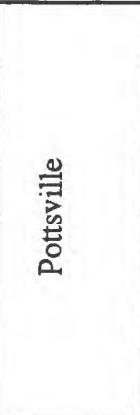 } & $\begin{array}{l}\text { Succession of sandstone, shales, clays, coals, and thin limestones. Locally, } \\
\text { sandstones are open-textured, conglomeratic, massive, cross-bedded, and com- } \\
\text { monly are found as deposits filling old channels in eroded terrains. Lateral } \\
\text { gradations include shale and coal. Non-depositions during the Early } \\
\text { Pennsylvanian precluded the development of the basal conglomerate of the } \\
\text { Sharon Member in most of southeastern Ohio. }\end{array}$ & $\begin{array}{l}\text { No. } 3 \text { Lower Mercer } \\
\text { No. } 2 \text { Quakertown } \\
\text { No. } 1 \text { Sharon }\end{array}$ \\
\hline & & $\begin{array}{l}\text { Thin, discontinuous zone of impure nodular iron ore and ferruginous sandstone. } \\
\text { The unit marks the disconformity between Mississippian and Pennsylvanian } \\
\text { strata. Age of the deposit is conjectural, but, generally, it is included at the base } \\
\text { of the Pottsville Formation. }\end{array}$ & \\
\hline 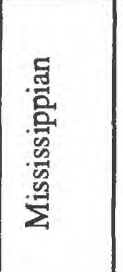 & 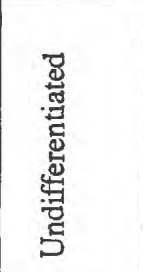 & $\begin{array}{l}\text { Variable sequence of sandstones and shales; Maxville Limestone is present in } \\
\text { patches at the top. In places, various units (Berea Sandstone, Black Hand } \\
\text { Sandstone Member of the Cuyahoga Formation, and Logan Formation) are con- } \\
\text { glomeratic and sandstones are massive. Lateral and vertical gradation to silt- } \\
\text { stone and shale is common. Ground-water potential is limited to extreme } \\
\text { western areas. Eastward, the section contains saltwater. To the north, post- } \\
\text { Mississippian erosion has removed the section. }\end{array}$ & \\
\hline
\end{tabular}

Figure 4. Generalized geologic column for southeastem Ohio, including relative position of important coal beds (Razem and Sedam, 1985). 


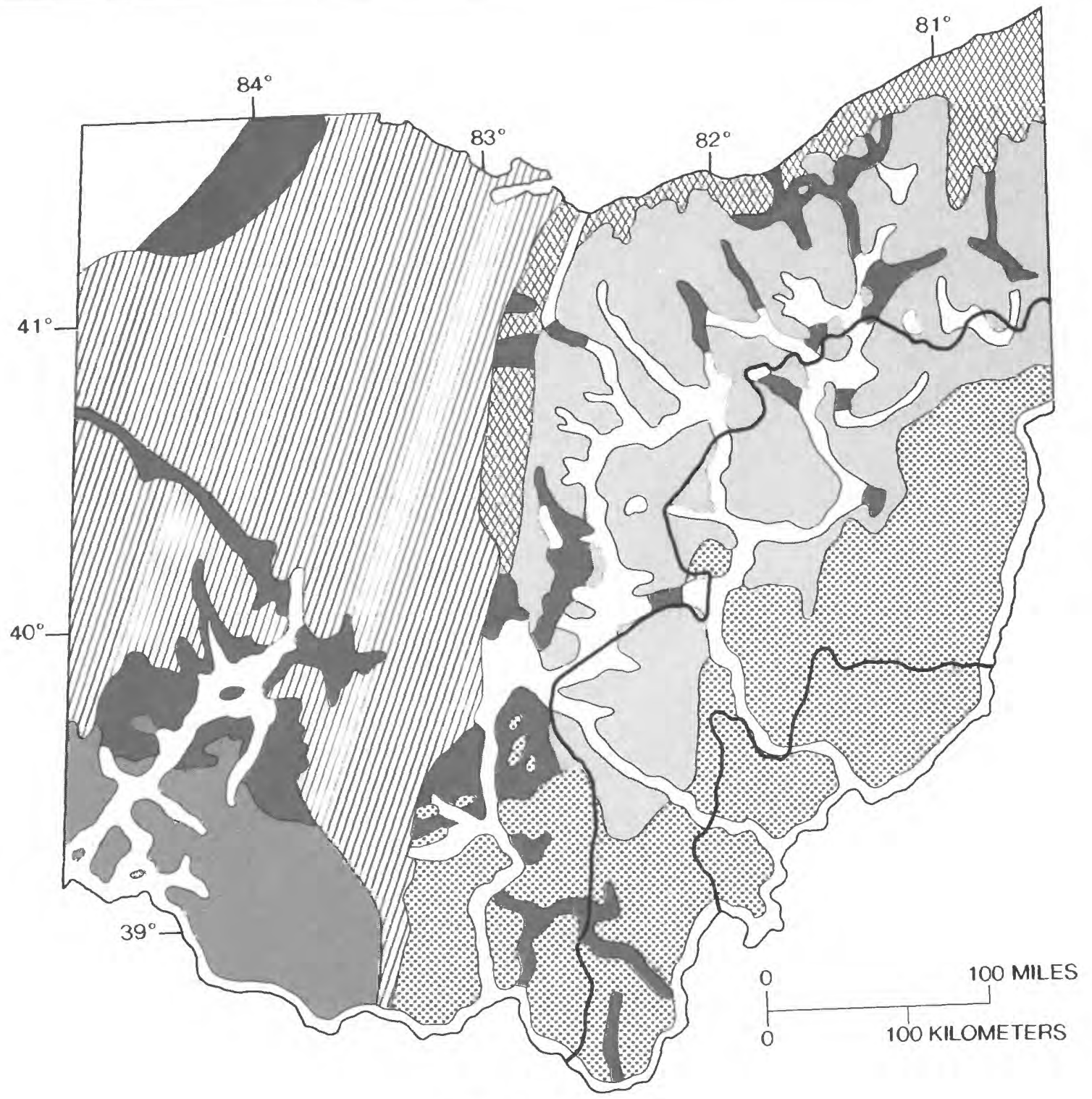

EXPLANATION

STUDY AREA BOUNDARY UNCONSOLIDATED AQUIFERS

Coarse grained

Fine grained
SEDIMENTARY BEDROCK AQUIFERS

Shaly sandstone and carbonate

Sandstone

Shale

Carbonate

Shaly carbonate

Figure 5.--Principal aquifers in Ohı. (Modified from Sedam and others, 1985. fig. 1.) 


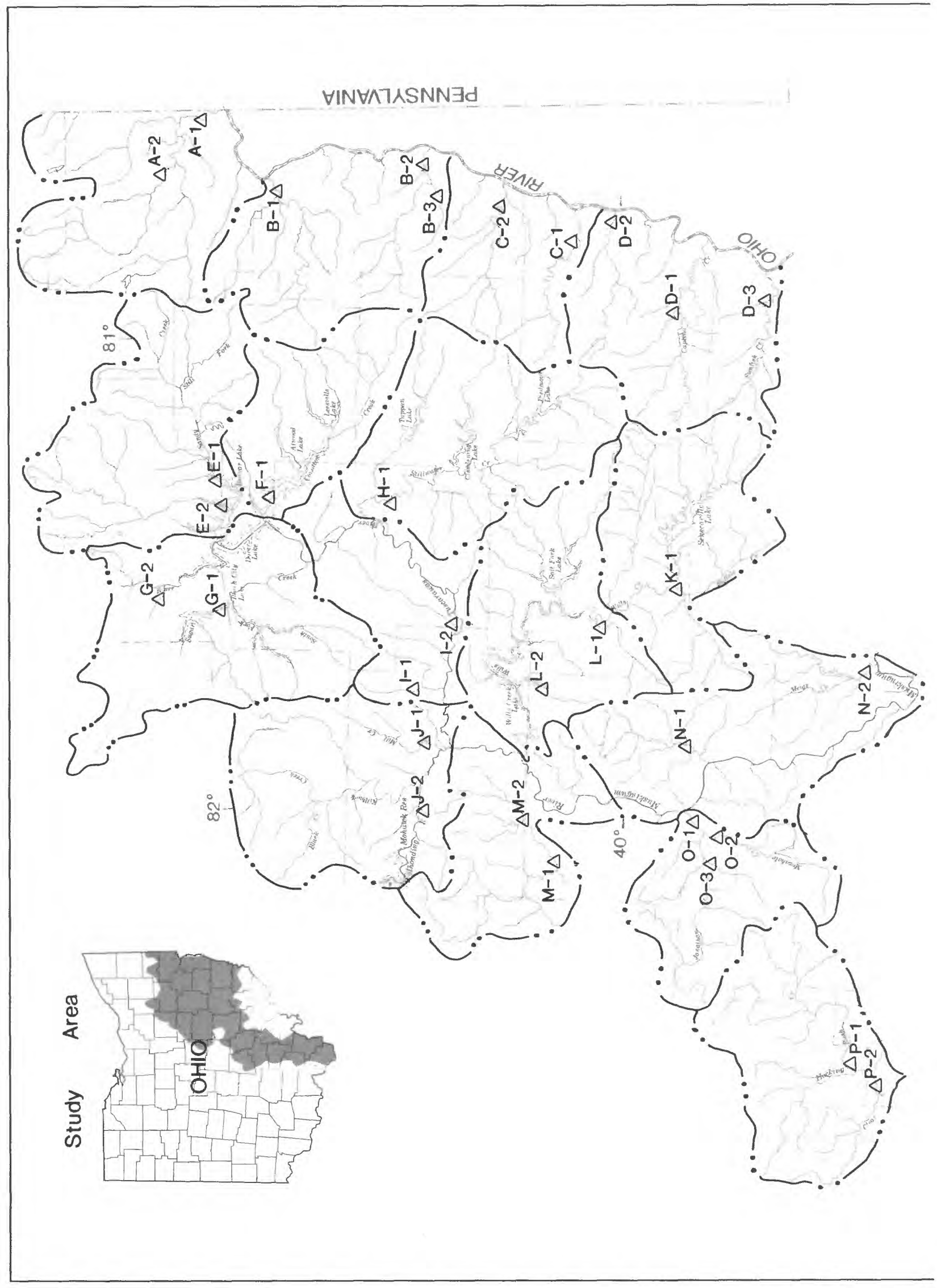




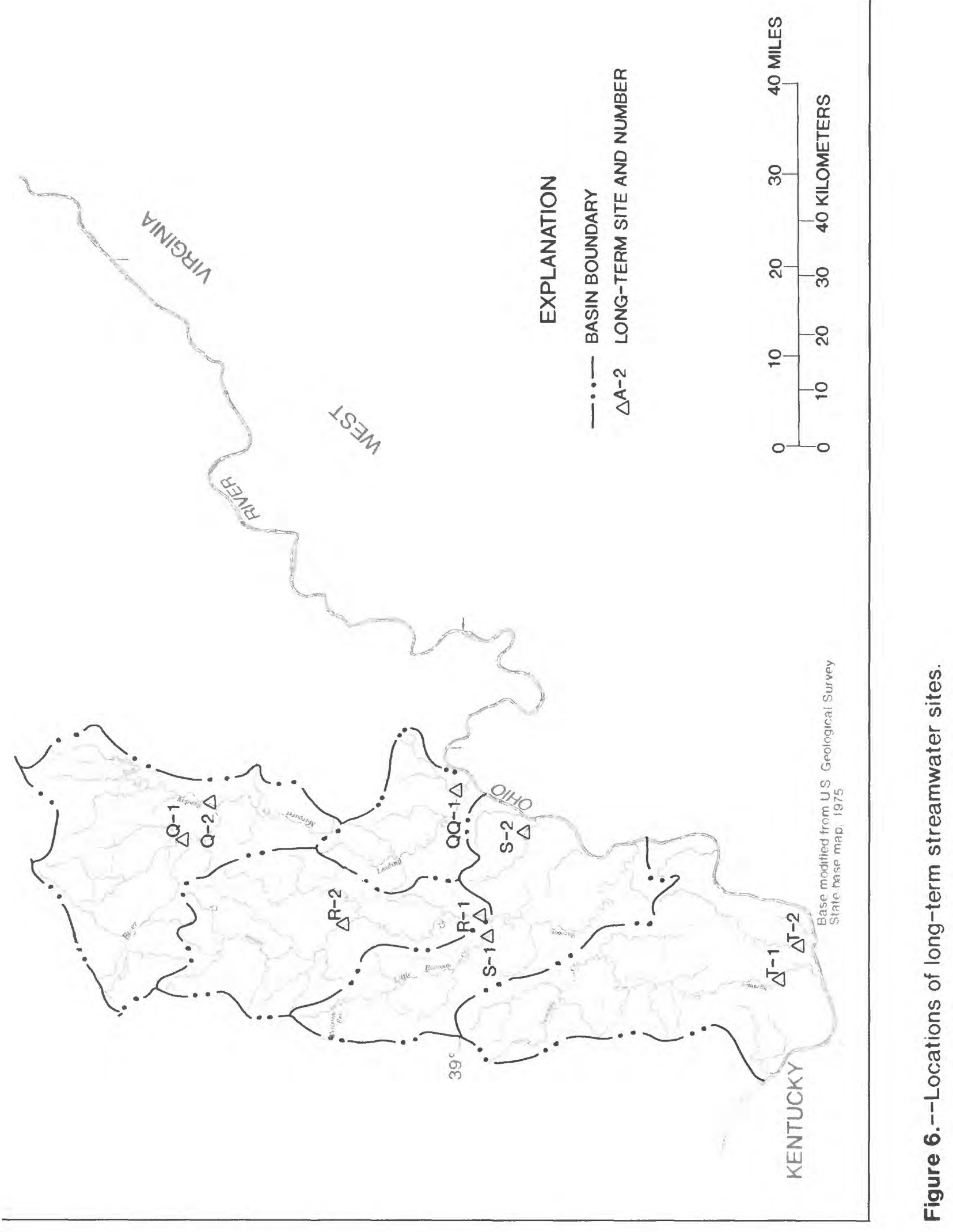


Superimposed on the northern edges of the study area and extending along alluvial channels cut in the bedrock are the unconsolidated aquifers of glacial and postglacial origin. The coarse-grained aquifers commonly yield 100 to $500 \mathrm{gal} / \mathrm{min}$ compared to 25 to $50 \mathrm{gal} / \mathrm{min}$ for the fine-grained types (Sedam and others, 1985, p. 342). Some of the coarsegrained aquifers consist of permeable sand and gravel deposits along modern streams; these are sometimes referred to as "watercourse" aquifers, and several such aquifers are present in the study area. Fine-grained aquifers include deposits in buried valleys, alluvium along modern streams, and permeable lenses in glacial drift.

Climatic data for the period $1931-80$ have been published in map form for Ohio (Harstine, 1991). This map shows that, although much of the study area receives 40 to 42 in. of precipitation annually, two cell-like areas (one south of Zanesville, the other north of Coshocton) receive only about 36 in. annually. The weather pattern for the period of this report (1989-91) varied considerably. The years 1989 and 1990 were unusually wet, and rainfall amounts were considerably above normal for most of the study area. In contrast, in 1991, rainfall amounts were considerably below normal and were similar to those in the dry years of 1987 and 1988. Based on rainfall summaries compiled by the ODNR, Division of Water (Cashell, 1988-91). The rainfall deficiency for 1988 and 1991 was 2 to $10 \mathrm{in}$. in eastern Ohio; in the same area in 1990 and 1991 , rainfall exceeded normal amounts by 2 to 15 in.

\section{Acknowledgments}

The author wishes to thank Vanessa Tolliver and Bill Sterling of the ODNR, Division of Reclamation, for their information concerning locations of coal-mining activity. The author also appreciates the cooperation of various commercial and municipal entities as well as individual property owners who allowed access to their wells or other datacollection sites.

\section{METHODS OF STUDY}

Locations of the long-term streamwater sites are shown in figure 6. In 1987, Leading Creek basin (fig. 1, basin QQ) was added, expanding the study area to 21 basins. With the addition of site QQ-1, the network was expanded to 41 long-term streamwater sites. Long-term streamwater sites were selected to represent general water quality in the basins under baseline conditions.

Streamflow measurements and collection of water samples were generally done for all 41 long-term sites twice annually, in late spring or early summer and in early autumn during low flow from 1989 through 1991. (For this study, low flow was a rate of flow exceeded 70 percent or more of the time.) Because of high flow in autumn 1990, this sampling was postponed until spring at some sites. Stage levels at several USGS continuous-record streamflow-gaging stations in southeastern Ohio were monitored to determine when streamflow would be appropriate for sampling.

During the final phase of the project (198991), 10 drainage basins were selected for a one-time synoptic data collection. The shortterm streamwater sites for synoptic study were chosen for geographic coverage of the basins. Streamflows were measured and water samples were collected at 45 short-term streamwater sites in 9 of the 10 drainage basins. In autumn 1989, work was done at 15 sites in Conotton Creek, Lower Wills Creek, and Upper Hocking River Basins (fig. 1, basins F, L, and P). Streamflows were measured and water samples were collected in spring 1991 at 15 sites in the Yellow and Cross Creeks, Walhonding River, and Upper Muskingum River basins (fig. 1, basins B, J, and M). In autumn 1991, work was done at 15 sites in the 
Middle Muskingum River, Middle Hocking River, and Leading Creek basins (fig. 1, basins $\mathrm{N}, \mathrm{Q}$, and QQ). Because of two previous studies in Raccoon Creek basin (Wilson, 1985, 1988), no short-term streamwater sites were chosen in the Lower Raccoon Creek basin (fig. 1, basin S) for synoptic data collection.

In the 10 drainage basins selected for synoptic data collection, short-term ground-water sites were chosen to represent water quality in shallow, productive aquifer(s) in the basin. Ground-water-resource maps and drillers' logs on file at ODNR, Division of Water, were used to locate prospective areas of shallow ground water and well locations that could be used for sampling. Much of the study area is served by water wells supplying small amounts for domestic purposes. The wells range from shallow (less than $50 \mathrm{ft}$ ) to deep (more than $50 \mathrm{ft}$ ), but most produce water from bedrock. The investigation focused on aquifers that could serve as a public or industrial water supply. Shallow, productive aquifers were found in 7 of the 10 basins. Water levels were measured when possible, and water-quality samples were collected from 28 wells during late summer and autumn 1991 as part of the onetime synoptic sampling.

Measurements of streamflow, specific conductance, $\mathrm{pH}$, temperature, alkalinity, and acidity were made at each streamwater site. Streamflow was measured by the methods described in Rantz and others (1982). Specific conductance, $\mathrm{pH}$, temperature, and alkalinity were determined by the methods discussed in Fishman and Friedman (1989). For water samples having $\mathrm{pH}$ greater than 6.5 , alkalinity was determined by fixed-endpoint titration. Acidity was determined on water samples having $\mathrm{pH}$ less than 5.0 by use of the hot-peroxide-treatment method (American Public Health Association, 1985). If the $\mathrm{pH}$ of the stream was 5.0 to 6.5 , both alkalinity and acidity were determined. Water samples for chemical analysis were collected according to the equal-transit-rate/equal-width-increment method (U.S. Geological Survey, Office of Water Data Coordination, 1977) for all streams deeper than $0.5 \mathrm{ft}$. For streams shallower than $0.5 \mathrm{ft}$, grab samples were collected. Samples were analyzed for concentrations of dissolved sulfate and for total recoverable and dissolved iron, manganese, and aluminum at the USGS National Water Quality Laboratory in Arvada, Colo.

Ground-water sampling procedures consisted of selecting wells in current use, inspecting the system to avoid treatment devices, and allowing the well to pump long enough to ensure that the water sample was representative of the formation. Ground water was considered to be representative of the formation when water-quality properties (specific conductance, $\mathrm{pH}$, and temperature) stabilized. Field measurements were made in a sample bucket for specific conductance, $\mathrm{pH}$, dissolved-oxygen concentration, and temperature according to the methods discussed in Fishman and Friedman (1989). Alkalinity was determined by fixed-endpoint titration, and bicarbonate concentration was calculated from the alkalinity. Water levels were measured by use of a steel tape when possible.

Laboratory analyses of ground-water samples were done at the USGS National Water Quality Laboratory and included concentrations of the following constituents:

Total recoverable and dissolved aluminum Dissolved sulfate

Total recoverable and dissolved iron

Total recoverable and dissolved manganese

Dissolved silica

Dissolved calcium

Dissolved magnesium

Dissolved sodium

Dissolved chloride

Dissolved potassium

Dissolved organic carbon

Total dissolved solids (residue on evaporation at $180^{\circ} \mathrm{C}$ ). 
Total hardness was calculated from the sums of the concentrations of calcium and magnesim, and noncarbonate hardness was calculated by subtracting the alkalinity from total hardness. In some sample analyses, the amounts of dissolved iron, aluminum, or manganese exceeded the total recoverable concentrations found for the same constituent. This difference was generally less than 10 percent, and is not unusual given the analytical accuracy.

\section{WATER QUALITY OF THE STUDY AREA, 1989-91}

Local geology and the extent to which the area has been mined are two important factors that can affect water quality of streams and local aquifers within the study area. Acid mine drainage can cause degradation of streamwater quality in mined areas and can be a potential threat in unmined areas. In addition to acid mine drainage, increased concentrations of constituents that can adversely affect aquatic biota of the stream may be present as a result of mining (Wangsness, 1982).

The principal source of acid mine drainage is the widespread presence of sulfur-bearing minerals, such as pyrite and marcasite, in coalbearing strata. Mining exposes these minerals to air and water. This exposure leads to chemical changes, such as the oxidation of sulfides to sulfates, that commonly result in increased acidity to surface runoff. In some places, limestone is present and serves as a buffer by neutralizing some of the acidic drainage.

\section{Streamwater at Long-Term Sites, 1989-91}

The 41 long-term sites were sampled 6 times between August 1989 and October 1991 to obtain a total of 246 samples. Specific conductance, $\mathrm{pH}$, alkalinity, and (or) acidity; concentrations of dissolved sulfate, iron, manganese, and aluminum; and concentrations of total recoverable iron, manganese, and alumi- num were used to assess the baseline water quality of major streams in the study area. Ranges and medians of these properties and constituents are summarized in table 2 for the 41 long-term surface-water sites. Site identifiers for lower- and upper-range values correspond to the long-term site-sampling locations shown in figure 6 . Ranges and percentiles (including medians) of constituents are presented graphically in figure 7 , and detailed analyses are given in table 31 at the back of the report.

Specific conductance, the ability of a substance to conduct electricity, increases as ion concentration increases (Hem, 1989). Among the 246 samples from the long-term site network, median specific conductance was 792 $\mu \mathrm{S} / \mathrm{cm}$ and the range was $270 \mu \mathrm{S} / \mathrm{cm}$ (at site T1) to $5,170 \mu \mathrm{S} / \mathrm{cm}$ (at site QQ-1). Specific conductance was greater than $1,000 \mu \mathrm{S} / \mathrm{cm}$ for all six sampling rounds at nine sites: B-2, B-3, $\mathrm{C}-1, \mathrm{C}-2, \mathrm{~K}-1, \mathrm{M}-2, \mathrm{~N}-2, \mathrm{O}-1$, and $\mathrm{O}-2$.

The $\mathrm{pH}$ of natural waters is a measure of the acid-base equilibrium achieved by the various dissolved compounds, salts, and gases. Values of $\mathrm{pH}$ less than 7 indicate acidic solutions, and those greater than 7 indicate alkaline solutions. Values of $\mathrm{pH}$ in the acidic range were found at sites $\mathrm{O}-1, \mathrm{O}-2, \mathrm{Q}-1$, and Q-2. Of the 24 samples collected in 1989 to 1991 at these sites, the $\mathrm{pH}$ ranged from 2.7 to 6.7 and the median was 3.4. For these 24 samples, specific conductances were high, ranging from 809 to $2,180 \mu \mathrm{S} / \mathrm{cm}$. The high specific conductance and low $\mathrm{pH}$ found at these sites are characteristic of water affected by coal mining. In contrast, $\mathrm{pH}$ of samples from sites B-2, B-3, $\mathrm{C}-1, \mathrm{C}-2, \mathrm{~K}-1, \mathrm{M}-2$, and $\mathrm{N}-2$ was in the alkaline range, although specific conductances at these sites were greater than $1,000 \mu \mathrm{S} / \mathrm{cm}$. For these sites, acid mine drainage may have been neutralized by interaction with carbonates present as limestone or calcareous shales and sandstones. In the set of 246 samples collected at the long-term streamwater sites, 140 of the $\mathrm{pH}$ values were 7.8 or greater. 
Table 2. Ranges and medians for selected water-quality characteristics for long-term streamwater sites in active coal-mining areas of Ohio, 1989-91

[mg/L, milligrams per liter; $\mu \mathrm{g} / \mathrm{L}$, micrograms per liter; $\mu \mathrm{S} / \mathrm{cm}$, microsiemens per centimeter at 25 degrees Celsius]

\begin{tabular}{|c|c|c|c|}
\hline $\begin{array}{l}\text { Property or } \\
\text { constituent }\end{array}$ & Range & $\begin{array}{l}\text { Locations }^{a} \\
\text { (fig. 6) }\end{array}$ & Median \\
\hline $\begin{array}{l}\text { Specific conductance, } \\
\text { in } \mu \mathrm{S} / \mathrm{cm}-\end{array}$ & $\begin{array}{l}270 \text { to } 5,170 \\
2.7 \text { to } 9.1\end{array}$ & $\begin{array}{l}\text { T-1; QQ-1 } \\
\mathrm{O}-2 ; \mathrm{A}-1\end{array}$ & $\begin{array}{l}792 \\
7.8\end{array}$ \\
\hline $\begin{array}{l}\text { Alkalinity, in } \mathrm{mg} / \mathrm{L} \\
\text { as } \mathrm{CaCO}_{3} \\
\text { Acidity, in } \mathrm{mg} / \mathrm{L}\end{array}$ & 1 to 391 & Q-1; K-1 & $\mathrm{b}_{116}$ \\
\hline $\begin{array}{l}\text { as } \mathrm{CaCO}_{3} \\
\text { Sulfate, dissolved, }\end{array}$ & 6 to 183 & O-1; Q-2 & $\mathrm{b}_{118}$ \\
\hline $\begin{array}{l}\text { in } \mathrm{mg} / \mathrm{L} \text { as } \mathrm{SO}_{4} \\
\text { Aluminum, total, }\end{array}$ & 13 to 2,100 & J-1; QQ-1 & 200 \\
\hline $\begin{array}{l}\text { in } \mu \mathrm{g} / \mathrm{L} \text { as } \mathrm{Al}-\cdots- \\
\text { Aluminum, dissolved, }\end{array}$ & 10 to 16,000 & D-3, M-1; Q-1 & 240 \\
\hline $\begin{array}{l}\text { in } \mu \mathrm{g} / \mathrm{L} \text { as } \mathrm{A} 1 \text { - } \\
\text { Iron, total, }\end{array}$ & $<10$ to 17,000 & Several sites; Q-1 & 30 \\
\hline $\begin{array}{l}\text { in } \mu \mathrm{g} / \mathrm{L} \text { as } \mathrm{Fe}- \\
\text { Iron, dissolved, }\end{array}$ & 20 to 54,000 & D-3; Q-2 & 610 \\
\hline $\begin{array}{l}\text { in } \mu \mathrm{g} / \mathrm{L} \text { as } \mathrm{Fe}- \\
\text { Manganese, total, }\end{array}$ & $<10$ to 53,000 & Several sites; Q-2 & 60 \\
\hline $\begin{array}{l}\text { in } \mu \mathrm{g} / \mathrm{L} \text { as } \mathrm{Mn}-\cdots- \\
\text { Manganese, dissolved, }\end{array}$ & 10 to 15,000 & D-3;O-2 & 355 \\
\hline in $\mu \mathrm{g} / \mathrm{L}$ as $\mathrm{Mn}$ & $<10$ to 17,000 & B-1, D-3; O-2 & 295 \\
\hline
\end{tabular}




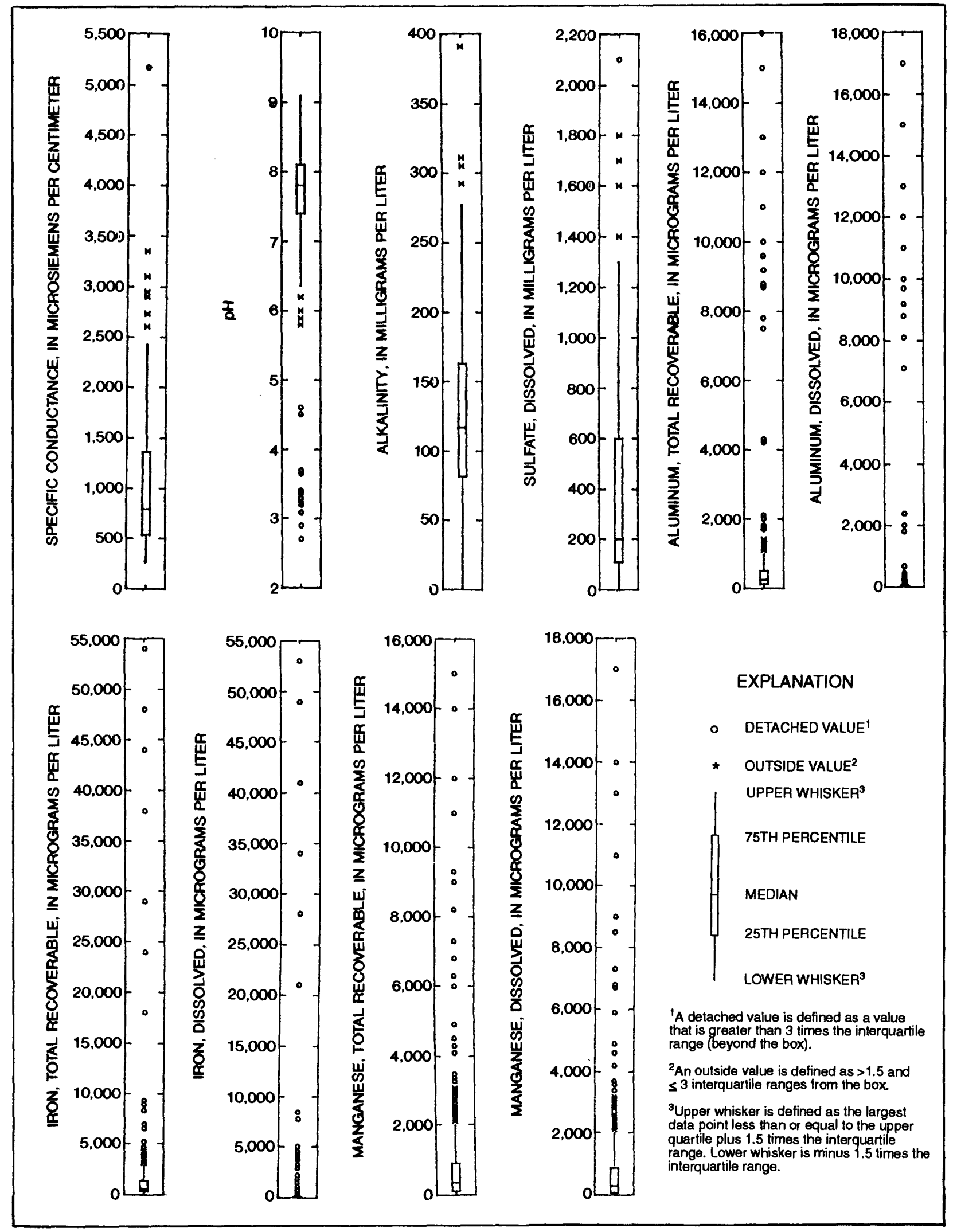

Figure 7.--Ranges, percentiles, and medians of constituents in 246 samples collected at 41 long-term streamwater sites in active coal mining areas of Ohio, 1989-91. 
"Buffering capacity," the ability to neutralize additions of acids or bases without a change in $\mathrm{pH}$, is controlled by the concentration of alkalinity and acidity in water (U.S. Environmental Protection Agency, 1986). The median alkalinity in the long-term network was $116 \mathrm{mg} / \mathrm{L}$ as $\mathrm{CaCO}_{3}$, and the range was $1 \mathrm{mg} / \mathrm{L}$ (at site Q-1) to $391 \mathrm{mg} / \mathrm{L}$ (at site K-1). Of the 246 samples collected, 21 had measurable acidity in the range of $6 \mathrm{mg} / \mathrm{L}$ as $\mathrm{CaCO}_{3}$ (at site $\mathrm{O}-1$ ) to $183 \mathrm{mg} / \mathrm{L}$ (at site Q-2) (table 31 ). High acidity is commonly associated with acid mine drainage.

The presence of high (greater than $250 \mathrm{mg} / \mathrm{L}$ ) dissolved-sulfate concentrations can be an indicator of drainage from coalmined areas. At four sites where $\mathrm{pH}$ was in the acidic range (sites $\mathrm{O}-1, \mathrm{O}-2$, Q-1, and Q-2), dissolved-sulfate concentrations also were high. Water from site QQ-1 had a wide range of dissolved-sulfate concentrations over the six samplings and had the highest dissolvedsulfate concentration of water from any site $(2,100 \mathrm{mg} / \mathrm{L}) ; \mathrm{pH}$ was greater than 7.0 at this site. Neutral or alkaline $\mathrm{pH}$ and high dissolved-sulfate concentrations were found at numerous other sites, including sites B-2, B-3, C-1, C-2, D-2, H-1, J-2, K-1, L-2, M-2, N-2, and $\mathrm{O}-3$. Data have shown that sulfate concentrations, once elevated, do not return to their premining levels, even after reclamation (Pfaff and others, 1981; Hren and others, 1984).

Concentrations of dissolved aluminum, iron, and manganese are known to be elevated during and immediately after mining (Dyer and Curtis, 1977). Water from sites O-2 and Q-1 had consistently high concentrations of all three metals, water from site Q-2 had high concentrations of iron and manganese, and water from site $\mathrm{O}-1$ had high concentrations of manganese. At all of these sites, $\mathrm{pH}$ was in the acidic range.

Aluminum is present only in small quantities in natural waters; however, waters whose $\mathrm{pH}$ is in the acidic range commonly have high concentrations of aluminum (Ward and Wilmoth, 1968). Concentrations of dissolved aluminum ranged from less than $10 \mu \mathrm{g} / \mathrm{L}$ (at several sites) to $17,000 \mu \mathrm{g} / \mathrm{L}$ (at site Q-1); the median was $30 \mu \mathrm{g} / \mathrm{L}$. The range of concentrations and the median concentration of total recoverable aluminum were similar to those for dissolved aluminum.

Concentrations of iron in water, though generally low, are strongly determined by the chemistry of the water (Hem, 1989). More than 1,000 to $2,000 \mu \mathrm{g} / \mathrm{L}$ of soluble iron in streamwaters generally indicates acidic contamination from mine drainage or other sources (Ward and Wilmoth, 1968). The concentration of dissolved iron ranged from less than $10 \mu \mathrm{g} / \mathrm{L}$ (at several sites) to $53,000 \mu \mathrm{g} / \mathrm{L}$ (at site Q-2). Concentrations of total recoverable iron ranged from $20 \mu \mathrm{g} / \mathrm{L}$ (at site D-3) to $54,000 \mu \mathrm{g} / \mathrm{L}$ (at site Q-2). The median concentration for total recoverable iron $(610 \mu \mathrm{g} / \mathrm{L})$ was about 10 times greater than the median concentration for dissolved iron $(60 \mu \mathrm{g} / \mathrm{L})$.

Small amounts of manganese are present in dolomite and limestone as a substitute for calcium. More than $1,000 \mu \mathrm{g} / \mathrm{L}$ of dissolved manganese can be present in streams receiving acid mine drainage (Hem, 1989). Concentrations of dissolved manganese ranged from less than $10 \mu \mathrm{g} / \mathrm{L}$ (at sites B-1 and D-3) to $17,000 \mu \mathrm{g} / \mathrm{L}$ (at site $\mathrm{O}-2$ ); the median was $295 \mu \mathrm{g} / \mathrm{L}$. The range of concentrations and the median concentration of total recoverable manganese were similar to those for dissolved manganese.

In most samples from the Middle Hocking River basin (fig. 1, basin Q) and Moxahala Creek basin (fig. 1, basin O), $\mathrm{pH}$ was in the acidic range, and high concentrations of the constituents commonly associated with acid mine drainage were present, including sulfate, iron, aluminum, and manganese. The remnants of past mining activities are clearly visible in the basins. 


\section{Ground Water}

Coal-mining activity can affect the flow or quality of ground water in an aquifer, especially in shallow aquifers in the same small watershed that is being mined (Eberle and

Razem, 1985). Shallow sources of ground water are present in many places throughout the coal-bearing region of eastern Ohio; however, those that are capable of furnishing enough water for commercial or small industrial purposes are mostly restricted to a few major valleys. The unconsolidated alluvial deposits along the Ohio River valley are not included in the scope of this study.

In this study, the water quality of shallow, productive ground-water sources along Conotton Creek, Walhonding River, and Lower Wills Creek were evaluated (fig. 1, basins F, J, and L, respectively). Farther south, shallow, productive sources of ground water were evaluated in the Upper and Middle Hocking River drainage basins (fig. 1, basins $P$ and Q) and Upper and Middle Muskingum River drainage basins (fig. 1, basins $\mathrm{M}$ and $\mathrm{N}$ ).

Elsewhere, shallow ground-water sources, whether in bedrock or unconsolidated material, are localized and, compared with the types just described, yield relatively small quantities of water to wells. This situation is characteristic of ground water in Yellow and Cross Creeks, Leading Creek, and Lower Raccoon Creek basins (fig. 1, basins B, QQ, and S, respectively); therefore, ground-water quality was not evaluated in these basins.

Analyses and dates of sampling for 28 ground-water sites in 7 basins are included in the discussion of the individual basins that follows this section. Locations of the 28 sites are shown in figure 8 , and ranges and medians of selected constituents and physical properties are listed in table 3. Summary statistics and box plots were not done for ground-water samples because only four wells were sampled in each basin.
Hardness of water is defined as its content of metallic ions that react to produce solid boiler scale (Camp, 1963). In freshwater, hardness is derived primarily from calcium and magnesium ions, which are naturally dissolved from carbonate rock by slightly acidic rainwater in contact with carbon dioxide. Sources of hardness related to human activity include abandoned and active mines (Jones, 1988).

Qualitative descriptions of hardness used in this report are based on the following classification (U.S. Environmental Protection Agency, 1986)

\section{Description:}

Milligrams per liter

Soft. as $\mathrm{CaCO}_{3}$

Moderately hard 0-75

Hard $75-150$

Very hard $150-300$ $>300$

Carbonate hardness is considered equal to alkalinity and is chemically equivalent to the bicarbonates present (U.S. Environmental Protection Agency, 1986). If hardness exceeds alkalinity, the excess is reported as "noncarbonate hardness" (Hem, 1989). Ground water in the seven basins sampled had a median hardness of $292 \mathrm{mg} / \mathrm{L}$ as $\mathrm{CaCO}_{3}$; the range was from $140 \mathrm{mg} / \mathrm{L}$ (at Cs-150 and $\mathrm{Mu}-50$ ) to $730 \mathrm{mg} / \mathrm{L}$ (at At-70). Noncarbonate hardness ranged from $0 \mathrm{mg} / \mathrm{L}$ (at several sites) to $610 \mathrm{mg} / \mathrm{L}$ (at site At-70); the median was $59 \mathrm{mg} / \mathrm{L}$.

Ground-water samples were analyzed for concentrations of dissolved calcium, magnesium, sodium, and potassium. Calcium is a major constituent of many common rock minerals and is a major component of the solutes in most natural waters (Hem, 1989). For the 28 sites sampled, calcium concentrations ranged from 43 to $190 \mathrm{mg} / \mathrm{L}$, and the median was $78 \mathrm{mg} / \mathrm{L}$. Magnesium is dissolved from carbonate rocks. Magnesium concentrations ranged from 7 to $61 \mathrm{mg} / \mathrm{L}$, and the median was $20 \mathrm{mg} / \mathrm{L}$. In most natural waters, sodium con- 
centrations are much greater than potassium concentrations. The U.S. Environmental Protection Agency (1986) recommends a limit of $20 \mathrm{mg} / \mathrm{L}$ of sodium in water for very restricted sodium diets and $270 \mathrm{mg} / \mathrm{L}$ for moderately restricted diets. The range of sodium concentrations for the 28 sites sampled was 3.5 to $120 \mathrm{mg} / \mathrm{L}$, and the median was $18 \mathrm{mg} / \mathrm{L}$, whereas the range of potassium concentrations was 0.6 to $6.1 \mathrm{mg} / \mathrm{L}$, and the median was $1.8 \mathrm{mg} / \mathrm{L}$.

A Piper diagram (fig. 9) shows the ionic character of the ground water. Water types at most of the 28 sites are similar, except at two wells from the Middle Hocking River basin. Water from one well in this basin stands out in the Piper diagram by having less calcium and magnesium and more sodium plus potassium than the other wells in the study area. Indeed, water from well Hk-54 had the highest concentration of sodium in the study area $(120 \mathrm{mg} / \mathrm{L})$ (table 3). Water from another well in the Middle Hocking River basin stands out in the Piper diagram (fig. 9) by having a high concentration of sulfate and a low concentration of carbonate plus bicarbonate. The concentration of dissolved sulfate in water from well At-70 was $470 \mathrm{mg} / \mathrm{L}$, substantially higher than the median of $48 \mathrm{mg} / \mathrm{L}$. At this well, nearmaximum concentrations were found for other constituents-hardness $\left(730 \mathrm{mg} / \mathrm{L}\right.$ as $\left.\mathrm{CaCO}_{3}\right)$, noncarbonate hardness $(610 \mathrm{mg} / \mathrm{L})$, calcium $(190 \mathrm{mg} / \mathrm{L})$, magnesium $(61 \mathrm{mg} / \mathrm{L})$, and dissolved solids $(822 \mathrm{mg} / \mathrm{L})$.
Dissolved organic carbon (DOC) is a measure of the organic matter present in aqueous solution. Thurman (1985) lists $0.7 \mathrm{mg} / \mathrm{L}$ as an approximate concentration for DOC typical of natural ground water. In the seven basins sampled in this study, DOC concentrations ranged from 0.6 to $3.1 \mathrm{mg} / \mathrm{L}$; the median was $0.8 \mathrm{mg} / \mathrm{L}$.

As discussed in the streamwater section, high concentrations of iron, aluminum, and manganese may be associated with waters affected by acid mine drainage. High concentrations of aluminum are typically associated with low $\mathrm{pH}$. Because aluminum is virtually insoluble at the range of $\mathrm{pH}$ found for the 28 ground-water samples (7.0 to 7.9), dissolved aluminum concentrations ranged from less than 10 to $70 \mu \mathrm{g} / \mathrm{L}$, and the median was less than $10 \mu \mathrm{g} / \mathrm{L}$. Total recoverable aluminum concentrations were slightly higher. In contrast, under reducing conditions, iron is moderately soluble in water; concentrations of $50 \mathrm{mg} / \mathrm{L}$ have been found in water having a $\mathrm{pH}$ between 6 and 8 (Hem, 1989). Dissolved-iron concentrations ranged from less than 3 to $8,700 \mu \mathrm{g} / \mathrm{L}$; the median was $275 \mu \mathrm{g} / \mathrm{L}$. Concentrations of total recoverable iron were higher (median of $1,005 \mu \mathrm{g} / \mathrm{L}$ ). Ground water can contain more than $1.0 \mathrm{mg} / \mathrm{L}$ of manganese under some circumstances (Hem, 1989). In the 28 ground-water samples, however, median manganese concentrations for dissolved $(70 \mu \mathrm{g} / \mathrm{L})$ and total $(59 \mu \mathrm{g} / \mathrm{L})$ manganese were not excessive. 


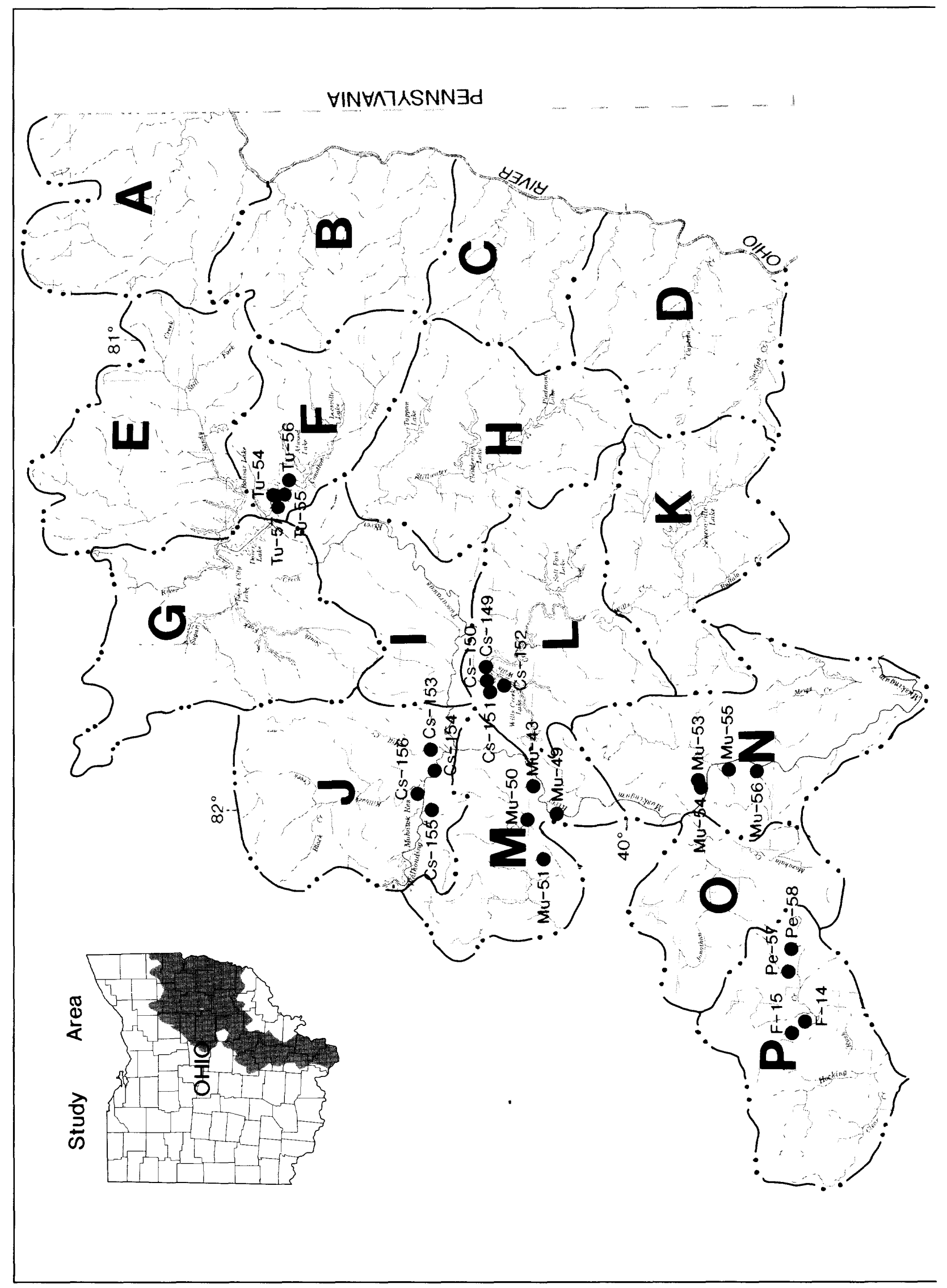




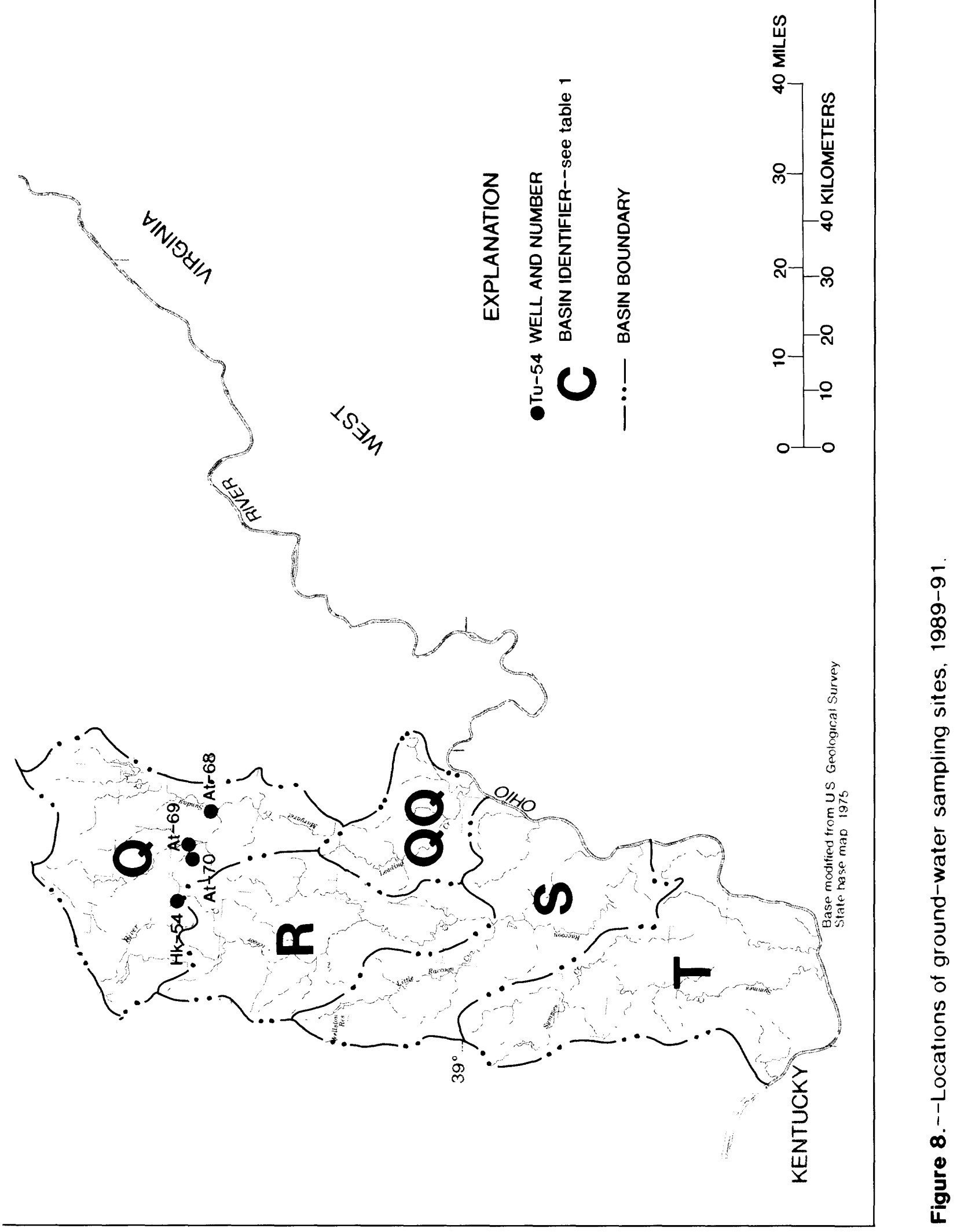


Table 3. Ranges and medians for selected water-quality characteristics for ground-water sites in active coal-mining areas of Ohio, 1989-1991

[mg/L, milligrams per liter; $\mu \mathrm{g} / \mathrm{L}$, micrograms per liter; $\mu \mathrm{S} / \mathrm{cm}$, microsiemens per centimeter at 25 degrees Celsius]

\begin{tabular}{|c|c|c|c|}
\hline $\begin{array}{l}\text { Property or } \\
\text { constituent }\end{array}$ & Range & $\begin{array}{c}\text { Locations }^{a} \\
\text { (fig. } 8 \text { ) }\end{array}$ & Median \\
\hline \multicolumn{4}{|l|}{ Specific conductance, } \\
\hline pH -.-.-- & 7.0 to 7.9 & $\mathrm{Cs}-152 ; \mathrm{Mu}-50$ & 7.4 \\
\hline \multicolumn{4}{|l|}{ Oxygen, dissolved, in } \\
\hline $\mathrm{mg} / \mathrm{L}$ & 0 to 8.1 & Cs-149; Cs-152 & 3.1 \\
\hline \multicolumn{4}{|l|}{ Hardness, in $\mathrm{mg} / \mathrm{L}$ as } \\
\hline $\mathrm{CaCO}_{3}$ & 140 to 730 & Cs-150, Mu-50; At-70 & 292 \\
\hline $\begin{array}{l}\text { Noncarbonate hardness, } \\
\text { in } \mathrm{mg} / \mathrm{L} \text { as } \mathrm{CaCO}_{3}\end{array}$ & 0 to 610 & Noncarbonate hardness, & 59 \\
\hline \multicolumn{4}{|l|}{ Calcium, dissolved, in } \\
\hline $\mathrm{mg} / \mathrm{L}$ as $\mathrm{Ca}$ & 43 to 190 & $\mathrm{Mu}-50 ; \mathrm{At}-70$ & 78 \\
\hline \multicolumn{4}{|l|}{ Magnesium, dissolved, in } \\
\hline $\mathrm{mg} / \mathrm{L}$ as $\mathrm{Mg}$ & 7 to 61 & Cs-150; At-70 & 20 \\
\hline \multicolumn{4}{|l|}{ Sodium, dissolved, in } \\
\hline $\mathrm{mg} / \mathrm{L}$ as $\mathrm{Na}-$ & 3.5 to 120 & Cs-154; Hk-54 & 18 \\
\hline \multicolumn{4}{|l|}{ Potassium, dissolved, in } \\
\hline \multicolumn{4}{|l|}{ Alkalinity, in $\mathrm{mg} / \mathrm{L}$ as } \\
\hline $\mathrm{CaCO}_{3}$ & 67 to 352 & Cs-152; F-14 & 229 \\
\hline \multicolumn{4}{|l|}{ Sulfate, dissolved, in } \\
\hline $\mathrm{mg} / \mathrm{L}$ as $\mathrm{SO}_{4}$ & $<1.0$ to 470 & Cs-149, Tu-55; At-70 & 48 \\
\hline $\begin{array}{l}\text { Chloride, dissolved, in } \\
\mathrm{mg} / \mathrm{L} \text { as } \mathrm{Cl}\end{array}$ & \multicolumn{2}{|c|}{ Chloride, dissolved, in } & 26 \\
\hline \multicolumn{4}{|l|}{ Silica, dissolved, in } \\
\hline $\mathrm{mg} / \mathrm{L}$ as $\mathrm{SiO}_{2}$ & 6.6 to 15 & Tu-55; Pe-58 & 10 \\
\hline $\begin{array}{l}\text { Solids, dissolved, sum of } \\
\text { constituents, in } \mathrm{mg} / \mathrm{L}\end{array}$ & 163 to 822 & $\mathrm{Mu}-50 ; \mathrm{At}-70$ & 413 \\
\hline Aluminum, total, in & & & \\
\hline$\mu \mathrm{g} / \mathrm{L}$ as $\mathrm{Al}$ & $<10$ to 250 & Several sites; Tu-55 & 10 \\
\hline Aluminum, dissolved in & & & \\
\hline $\begin{array}{l}\mu \mathrm{g} / \mathrm{L} \text { as } \mathrm{A} 1 \\
\text { Iron, total, in }\end{array}$ & $<10$ to 70 & Most sites; Pe-58 & $<10$ \\
\hline $\begin{array}{l}\text { Iron, total, in } \\
\mu \mathrm{g} / \mathrm{L} \text { as } \mathrm{Fe} \\
\end{array}$ & $<10$ to 9,800 & Cs-154; Pe-58 & 1,005 \\
\hline Iron, dissolved, in & & & \\
\hline$\mu \mathrm{g} / \mathrm{L}$ as $\mathrm{Fe}$ & $<3$ to 8,700 & Several sites; Tu-57 & 275 \\
\hline Manganese, total, in & & & \\
\hline$\mu \mathrm{g} / \mathrm{L}$ as $\mathrm{Mn}$ & $<10$ to 790 & Several sites; Mu-51 & 70 \\
\hline $\begin{array}{l}\text { Manganese, dissolved, in } \\
\mu \mathrm{g} / \mathrm{L} \text { as } \mathrm{Mn}\end{array}$ & $<1$ to 830 & $\mathrm{Cs}-154,155 ; \mathrm{Mu}-51$ & 59 \\
\hline $\begin{array}{l}\text { Carbon, organic, dissolved, } \\
\text { in } \mathrm{mg} / \mathrm{L} \text { as } \mathrm{C}\end{array}$ & 0.6 to 3.1 & Several sites; Mu-50 & .8 \\
\hline
\end{tabular}

\footnotetext{
${ }^{a}$ Sites at which the minimum values in the ranges were measured are to the left of the semicolon. Sites at which the maximum values in the ranges were measured are to the right of the semicolon
} 


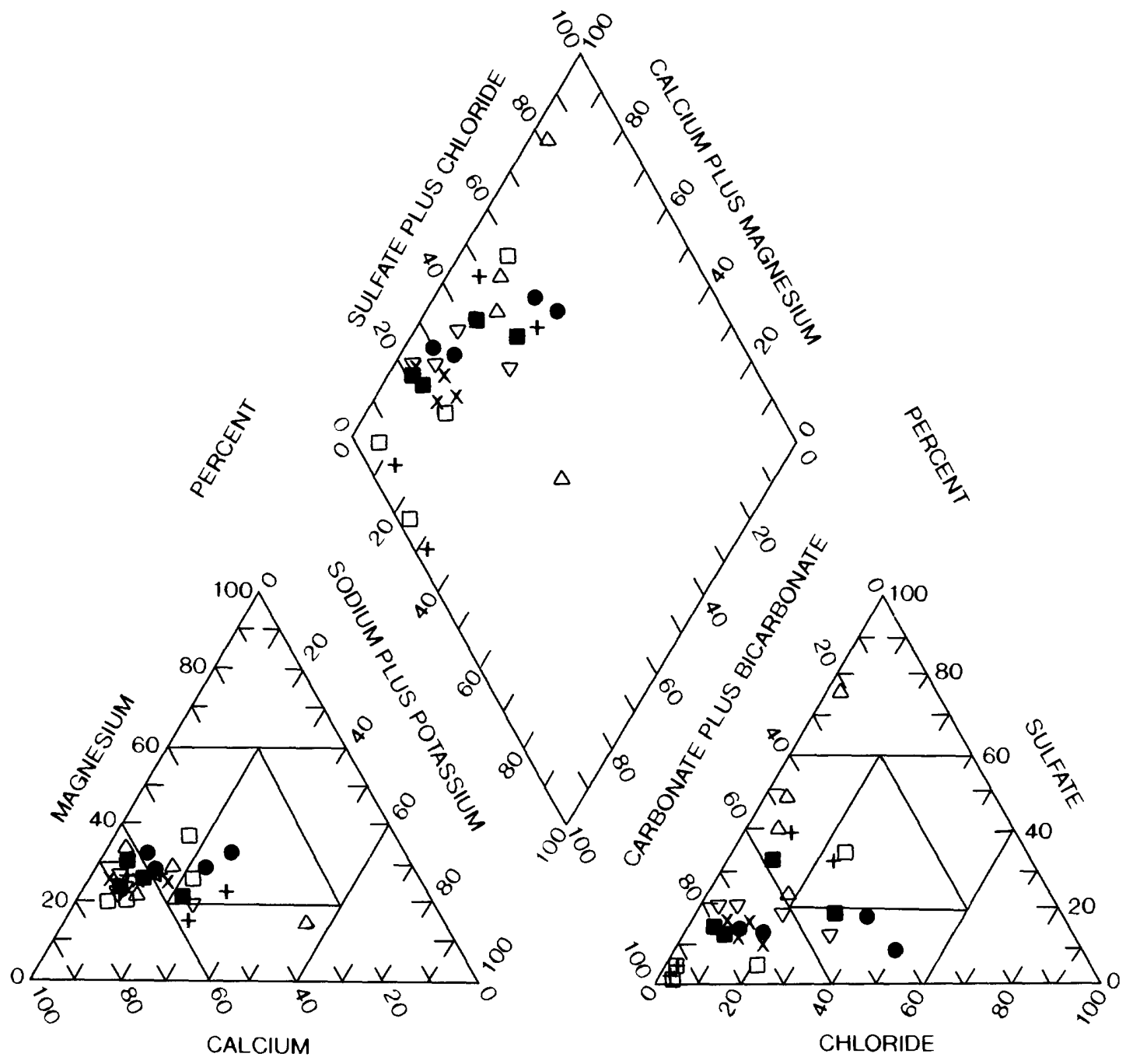

PERCENT

\section{EXPLANATION}

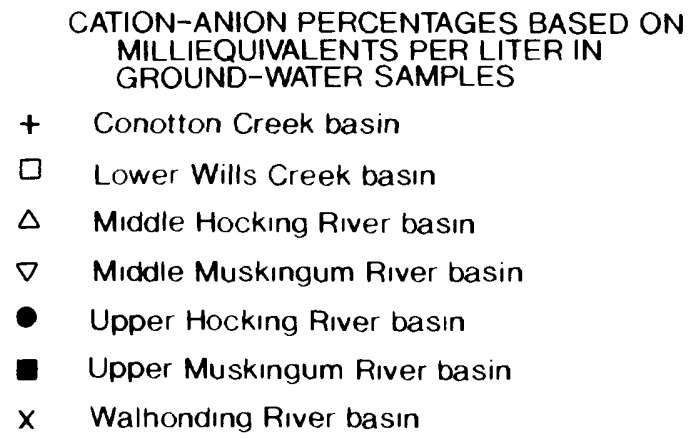

Figure 9.--Piper diagram showing distribution of constituents for ground-water sites sampled in active coal mınıng areas of Ohio, 1989-91. 
Because many ground-water sources are used for domestic or public supplies, the following Ohio Environmental Protection Agency (OEPA) (1989) drinking-waterquality standards are listed for reference (all concentrations are expressed as total concentrations unless otherwise noted):

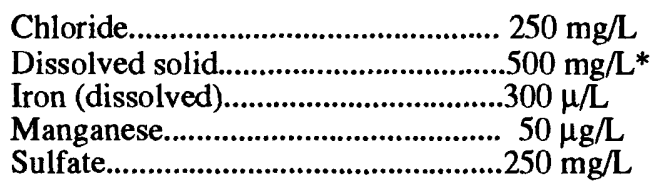

*Not to exceed $500 \mathrm{mg} / \mathrm{L}$ as a monthly average or $750 \mu \mathrm{g} / \mathrm{L}$ at any time (equivalent specific conductance values at 25 degrees Celsius are 800 and $1,200 \mu \mathrm{S} / \mathrm{cm}$, respectively).

\section{GEOLOGIC SETTING AND WATER QUALITY OF SELECTED BASINS}

Each of the 10 drainage basins selected for study in which synoptic measurements were made from 1989 to 1991 is described with respect to its physical setting and geologic framework in the following sections. The physiographic names used in the descriptions are based on designations by Fenneman (1938). Drainage areas mentioned in the text and in tables were derived from the "Gazetteer of Ohio Streams" (Krolczyk, 1954; Cross, 1967), and, in some instances, compiled from drainage-area maps maintained by the USGS.

Results of the synoptic ground-water and streamwater sampling in 10 drainage basins are presented in tables and figures in the discussions for each basin that follow. The synoptic streamwater sampling included collection of water-quality samples at 45 shortterm and 17 long-term sites in 9 of the 10 drainage basins. The synoptic groundwater sampling included collection of waterquality samples at 28 sites in 7 of the 10 drainage basins. Additional water-quality analyses for the long-term streamwater sites sampled during 1989-91 are listed in table 31 at the back of this report.

\section{Conotton Creek Basin}

Conotton Creek basin, with a drainage area of about $286 \mathrm{mi}^{2}$, is situated mostly in the southwestern half of Carroll County and extends into the northeastern part of Tuscarawas County and into the northern part of Harrison County (fig. 1, basin F). It lies entirely within the Unglaciated Allegheny Plateau Section of the Appalachian Plateaus Physiographic Province some 10 to $15 \mathrm{mi}$ south of the limit of glaciation.

Conotton Creek, the principal stream, follows a northwesterly course close to the southern side of the basin toward its confluence with the Tuscarawas River near Zoarville (fig. 10). Several tributaries to Conotton Creek flow generally to the southwest. Two of these tributaries, Indian Fork and McGuire Creek, have been dammed to form, respectively, Atwood and Leesville reservoirs (fig. 10). Much of the terrain along Conotton Creek is relatively flat, but elsewhere, such as northeastward along the upper reaches of the tributaries, the surface is rolling to moderately hilly.

\section{Geologic Setting}

The rocks consist of Pennsylvanian strata, which, from west to east and in ascending order, include the Pottsville, Allegheny, Conemaugh, and Monongahela Formations. As shown in figure 4, the stratigraphic section is a cyclic sequence of sandstones and shales interbedded with coal, clay, and limestone. Areally, the Conemaugh of Pennsylvanian age is the most extensive in the Conotton Creek basin. 


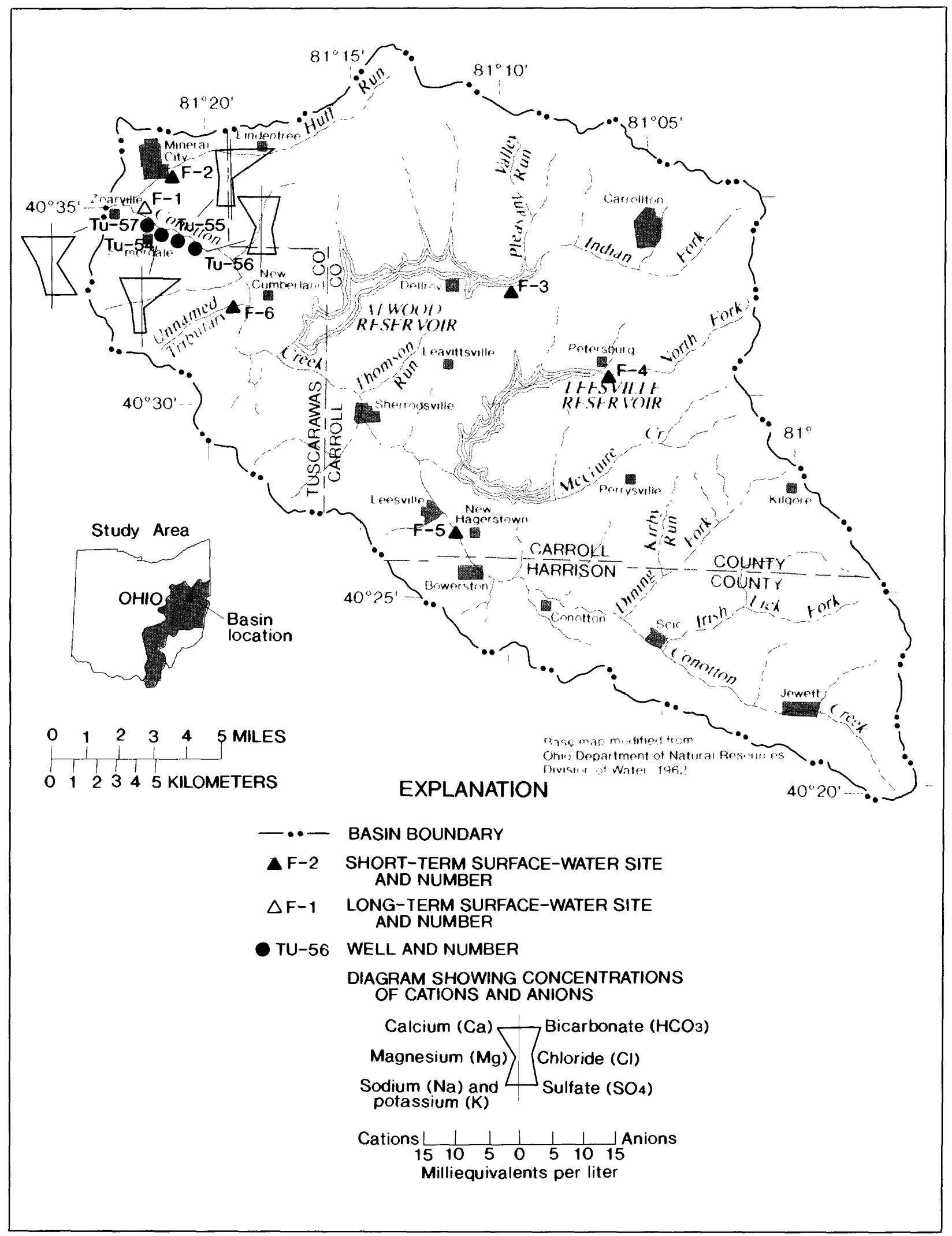

Figure 10.--Conotton Creek basin (F), streamwater sites, ground-water sites, and Stiff diagrams for ground-water sites. 


\begin{tabular}{cclc}
\hline $\begin{array}{c}\text { Map index } \\
\text { number }\end{array}$ & Site type & \multicolumn{1}{c}{ Site name } & $\begin{array}{c}\text { Drainage area } \\
\text { (square miles) }\end{array}$ \\
\hline & & & \\
F-1 & Long term & Conotton C nr Somerdale & 268 \\
F-2 & Short term & Huff Rn at Mineral City & 12.1 \\
F-3 & do. & Indian F nr Dellroy & 33.9 \\
F-4 & do. & NF McGuire C at Petersburg & 11.2 \\
F-5 & do. & Conotton C at Leesville & 87.1 \\
F-6 & do. & Unnamed Tr Conotton C nr & 5.5 \\
& & New Cumberland & \\
\hline
\end{tabular}

Areas of active coal mining are mostly along the western side of the basin, producing coal mainly from the Allegheny Formation. Active areas along the eastern side of the basin southeast of Carrollton also produce from the Allegheny Formation, as well as from the Harlem coal, a minor coal within the Conemaugh Formation. Some remnants of the Monongahela Formation are found in the southeastern corner of the basin in Harrison County. Although an important coal producer elsewhere in Ohio, the Monongahela coals in this area have been mined out.

Aquifers throughout the basin consist mostly of sandstones and thin fractured limestones. Potential yields to wells of as much as $25 \mathrm{gal} / \mathrm{min}$ from these units are possible, but, in the eastern half of the basin, yields typically are less than $5 \mathrm{gal} / \mathrm{min}$ (Schmidt, 1962a). Along the lower course of Conotton Creek, the valley is filled with unconsolidated sediments that are more than $100 \mathrm{ft}$ thick in places, and potential well yields can range from 5 to $25 \mathrm{gal} / \mathrm{min}$. Many wells in the area are cased into and yield from bedrock beneath the valley-fill sediments.

\section{Water Quality}

Synoptic collections of water samples were made at six stream sites and at four groundwater sites in the Conotton Creek basin. Half of the stream sites and all of the ground-water sites were in the western part of the basin (fig. 10), the area with most of the active mining.

The streamwater sites listed in the table above were sampled in mid-October 1989. Their locations are shown in figure 10.

The lower part of Conotton Creek consists mainly of pools of slow-moving water. Because of low water velocities in this area, streamflow measurements cannot be accurately made nor can representative waterquality samples be collected. As an alternative, long-term site F-1 was added for synoptic sampling. Site F-1 represents about 93 percent of the drainage area in the basin, including the lower part of Conotton Creek.

Water-quality data for the six streamwater sites in Conotton Creek basin are given in table 4. Water quality at site F-2 was different from that at the five other sites and was characterized by a lower $\mathrm{pH}$, a higher specific conductance, and higher concentrations of total recoverable and dissolved aluminum, iron, and manganese. At site F-2, constituent concentrations were at the top of the range for the study 
area, except for $\mathrm{pH}$ and alkalinity, which were at the bottom of the range (table 5). Box plots showing the ranges, percentiles, and medians of constituents for all sites in Conotton Creek basin (fig. 11) show that the concentrations of constituents at site F-2 were well outside the interquartile ranges. To a much lesser extent than site F-2, the water from site F-6 had higher specific conductance and higher concentrations of total recoverable and dissolved manganese, total recoverable iron, and dissolved sulfate than the other four sites.

The water quality at site F-2, and to a much lesser extent at site F-6, is characteristic of water affected by mining. Unrestored coalmining lands can be found in the northwestern part of Conotton Creek basin.

\section{Ground water}

Most wells in the Conotton Creek basin yield water from bedrock except along Conotton Creek, where wells are screened in layers of unconsolidated deposits. The four ground-water sites chosen for sampling were in and near the town of Somerdale (fig. 10). Three of these wells yield water from alluvial deposits along the valley of Conotton Creek (Tu-55, Tu-56, and Tu-57); Tu-54 is finished in the underlying bedrock. In general, the ground water used by the residents in the Somerdale area is derived from both aquifer types.

Water-quality data for four ground-water sites sampled in September 1989 are given in table 6. Values of $\mathrm{pH}$ ranged from 7.2 to 7.8, and, except for total and dissolved iron at three sites, concentrations of constituents associated with acid mine drainage were not high.

As shown by the Stiff diagrams (fig. 10), calcium was the principal cation at all four sites; however, the sites differed in anionic character. At sites Tu-56 and Tu-57, sulfate and bicarbonate were the major anions, and, at sites Tu-54 and Tu-55, sulfate concentrations were low and bicarbonate was the dominant anion.
The OEPA water-quality standards for public supplies for dissolved solids, chloride, and sulfate were not exceeded at any of the four sites. Water-quality standards for dissolved iron $(300 \mu \mathrm{g} / \mathrm{L})$ and manganese $(50 \mu \mathrm{g} / \mathrm{L})$, however, were exceeded at sites $\mathrm{Tu}-54, \mathrm{Tu}-55$, and Tu-57. The water from site Tu-56 met all OEPA water-supply standards for the constituents analyzed. The waters at all four sites can be classified as hard to very hard.

\section{Lower Wills Creek Basin}

The Lower Wills Creek basin, which is about $447 \mathrm{mi}^{2}$ in area, covers most of the northern half of Guernsey County, just touching Belmont County on the east, Tuscarawas County on the north, and extending into the southeastern corner of Coshocton County and the northeastern corner of Muskingum County (fig. 1, basin L). The Lower Wills Creek basin is in the Unglaciated Allegheny Plateau Section of the Appalachian Plateaus Physiographic Province. The northern edge of the basin is about $25 \mathrm{mi}$ south of the glacial limit.

Wills Creek, the principal stream, meanders across the central and northwestern part of the basin before it enters the Tuscarawas River system (fig. 12). Wills Creek is also the principal stream draining upper Wills Creek basin (fig. 1, basin K), described earlier (Sedam, 1991). The two basins are separated at a point upstream from and just south of Cambridge. The largest tributary within the Lower Wills Creek basin, Salt Fork, was dammed near its confluence with Wills Creek to create Salt Fork Reservoir, which extends into the lower reach of several tributaries to Salt Fork in the eastern part of the basin. Other principal tributaries to Wills Creek include Birds Run and Bacon Run in the north and White Eyes and Crooked Creeks in the western half of the basin (fig. 12). 
Table 4. Water-quality data for streamwater sites in Conotton Creek basin, October 1989

$\left[{ }^{\circ} \mathrm{C}\right.$, degrees Celsius; $\mathrm{ft}^{3} / \mathrm{s}$, cubic feet per second; $\mathrm{mg} / \mathrm{L}$, milligrams per liter; $\mu \mathrm{g} / \mathrm{L}$, micrograms per liter; $\mu \mathrm{S} / \mathrm{cm}$, microsiemens per centimeter at 25 degrees Celsius; --, data not available]

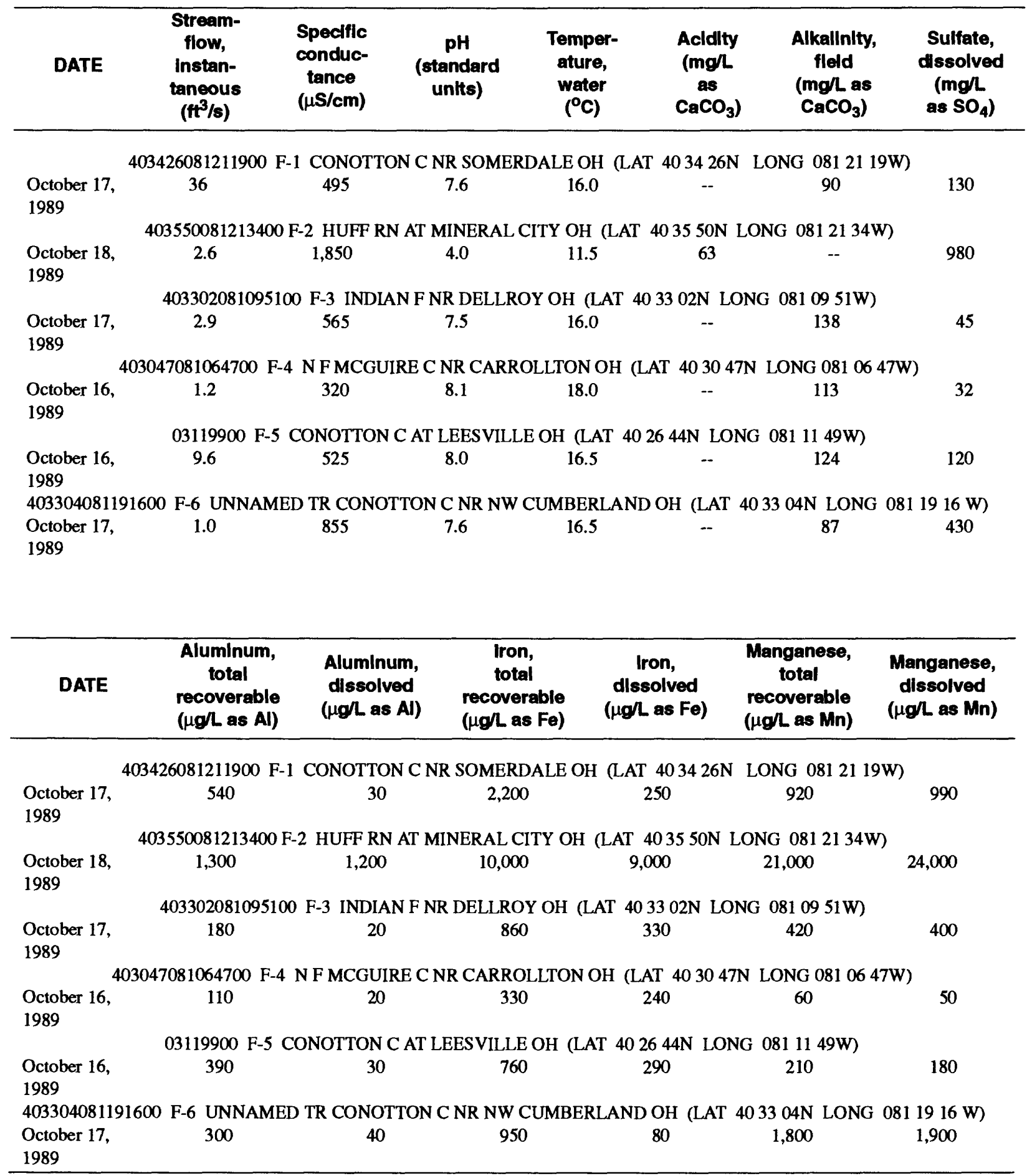


Table 5. Ranges and medians for selected water-quality characteristics for streamwater sites in Conotton Creek basin, October 1989

[mg/L, milligrams per liter; $\mu \mathrm{g} / \mathrm{L}$, micrograms per liter; $\mu \mathrm{S} / \mathrm{cm}$, microsiemens per centimeter at 25 degrees Celsius]

Property or

constituent
Range

\section{Locations $^{\mathrm{a}}$}

(fig. 10)
Median

Specific conductance,

in $\mu \mathrm{S} / \mathrm{cm}$-...-...-...

$\mathrm{pH}-$

Alkalinity, in $\mathrm{mg} / \mathrm{L}$

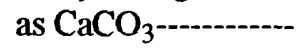

Sulfate, dissolved, in $\mathrm{mg} / \mathrm{L}$ as $\mathrm{SO}_{4}$

Aluminum, total, in $\mu \mathrm{g} / \mathrm{L}$ as $\mathrm{Al}------$

Aluminum, dissolved, in $\mu \mathrm{g} / \mathrm{L}$ as $\mathrm{A} 1$------

Iron, total, in $\mu \mathrm{g} / \mathrm{L}$ as $\mathrm{Fe}---$

Iron, dissolved, in $\mu \mathrm{g} / \mathrm{L}$ as $\mathrm{Fe}-------$

Manganese, total, in $\mu \mathrm{g} / \mathrm{L}$ as $\mathrm{Mn}---$-.- $^{-}$

Manganese, dissolved, in $\mu \mathrm{g} / \mathrm{L}$ as $\mathrm{Mn}$-------
320 to 1,850

4.0 to 8.1

87 to 138

32 to 980

110 to 1,300

20 to 1,200

330 to 10,000

80 to 9,000

60 to 21,000

50 to 24,000
F-4; F-2

F-2; F-4

550 7.6

F-6; F-3

$b_{113}$

F-4; F-2

125

F-4; F-2

345

F-3, 4; F-2

30

F-4; F-2

905

F-6; F-2

270

F-4; F-2

670

F-4; F-2

695

${ }^{a}$ Sites at which the minimum values in the ranges were measured are to the left of the semicolon. Sites at which the maximum values in the ranges were measured are to the right of the semicolon.

b Median was calculated on the basis of only those samples for which alkalinity could be measured (see "Methods," p. 14). 


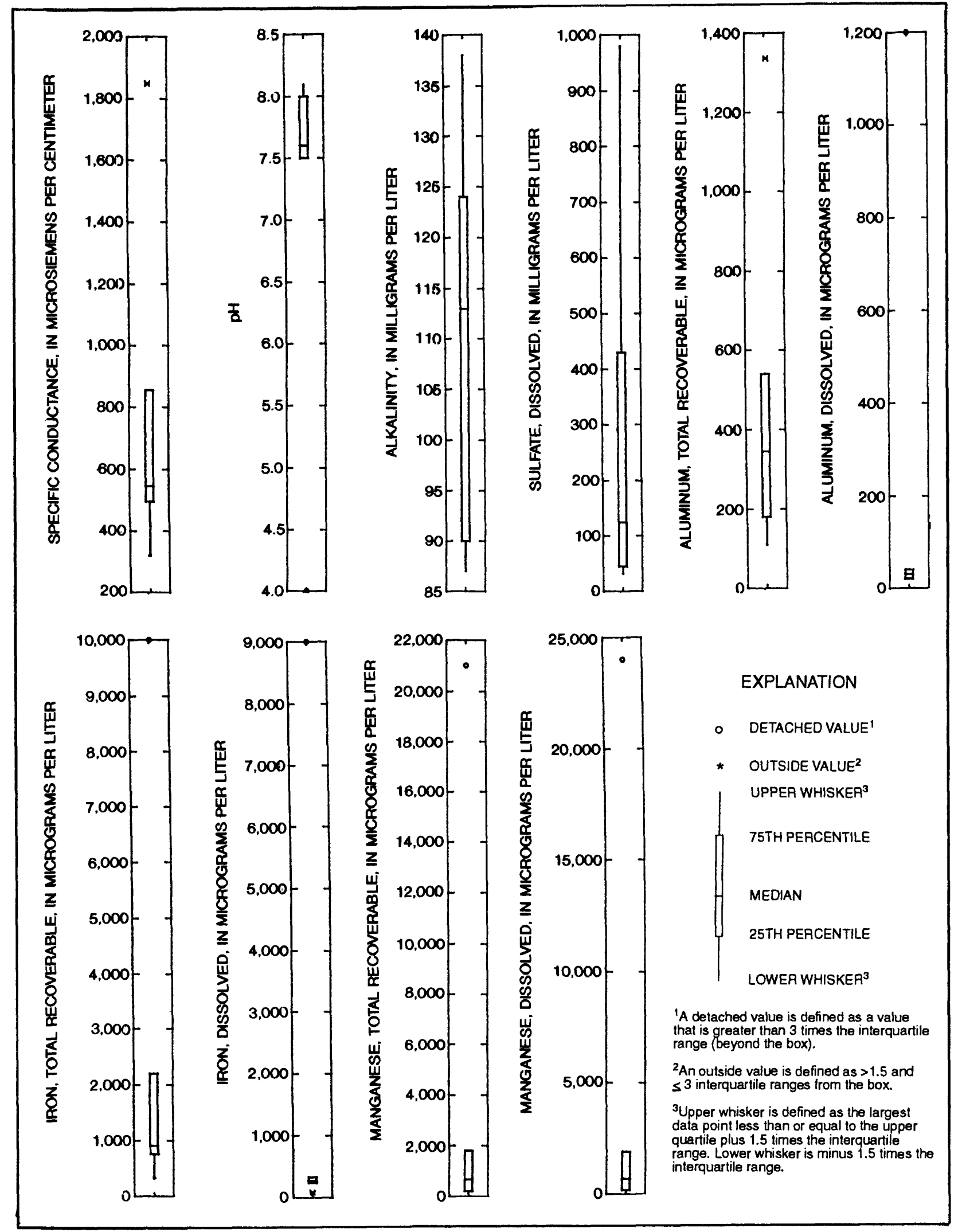

Figure 11.--Ranges, percentiles, and medians of constituents at six streamwater sites in the Conotton Creek basin. 


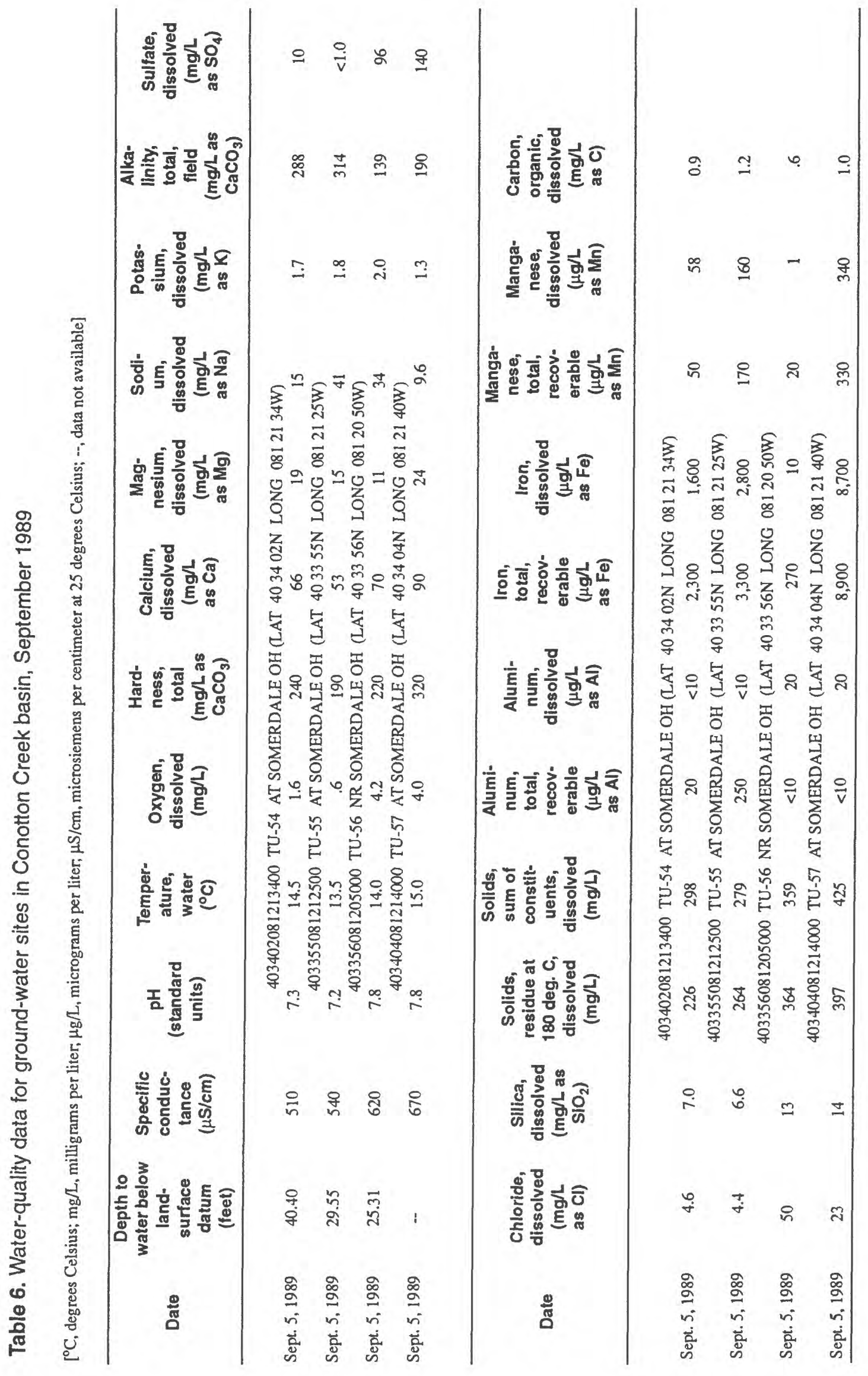




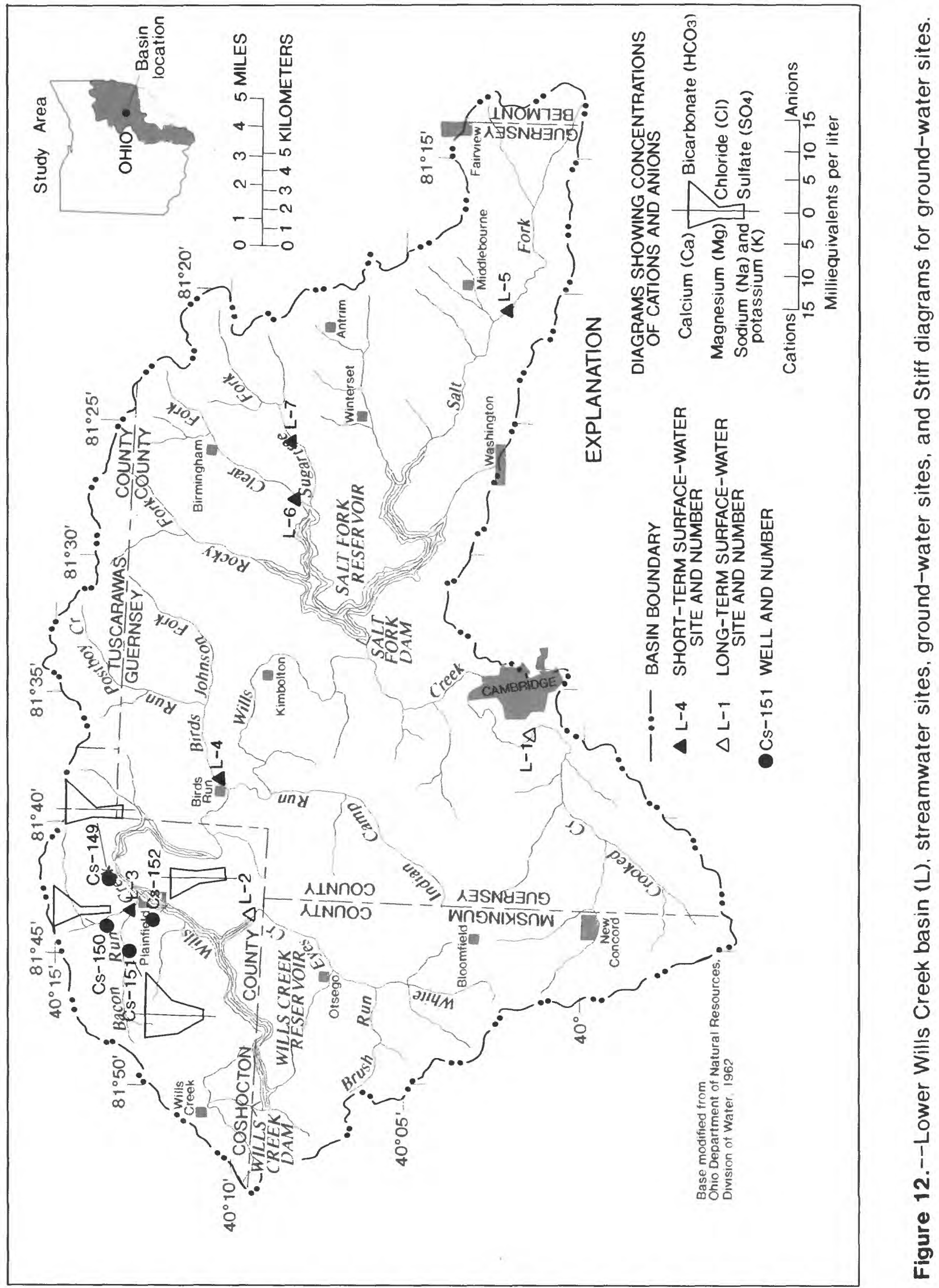


Erosion of the land surface has produced a thoroughly dissected terrain, characterized by wide bottomlands and low hills. Toward the periphery of the basin, near the headwaters of the smaller tributaries, the terrain is more rugged. In contrast, much of the terrain along the lower reach of Wills Creek is wetland.

\section{Geologic Setting}

From northwest to southeast across Lower Wills Creek basin, the stratigraphic succession, in ascending order, includes the four major formations of Pennsylvanian age (fig. 4). In the northwest, the Pottsville Formation is present in valley floors in the southeastern corner of Coshocton County and adjacent parts of Guernsey County. In the same area, the uplands consist mostly of the Allegheny Formation and its mineable coals; in places, the uplands are capped by remnants of the Conemaugh Formation. The Conemaugh forms the surface over much of the rest of the basin, and, toward the southeastern corner, scattered remnants of the Monongahela Formation are found at higher elevations. Because of the Cambridge Arch, as described by Lamborn (1951), the rock strata are structurally high in the northwestern to the central part of the basin. This has led to erosion of much of the Conemaugh Formation and exposure of the underlying Allegheny Formation along Wills Creek between Cambridge and Kimbolton (fig. 12). As of 1989, most active permits to mine coal were for the northern part of the basin, where Allegheny coals are common.

In general, ground-water yields from bedrock are meager in the Lower Wills Creek basin. Well yields of 3 to $5 \mathrm{gal} / \mathrm{min}$ or less are found in upland areas in the northwestern part of the basin. Similar low yields are common in the eastern part of the basin where the Conemaugh Formation is the principal underlying unit. In the northwestern part of the basin, however, wells tapping bedrock yield as much as $25 \mathrm{gal} / \mathrm{min}$ (Walker, 1962b; Sugar,
1988 ) in some places. Such places are likely to be where permeable units of the Pottsville or Allegheny Formation are present at or below stream level.

Unconsolidated deposits making up the valley fill along Wills Creek can yield as much as $25 \mathrm{gal} / \mathrm{min}$. Many of these potential sources underlie wetland areas, and thus are likely to remain undeveloped. An exception is the area around Plainfield, where the bottomlands along Wills Creek and adjacent tributaries are underlain by sediments that, in places, are 80 to $100 \mathrm{ft}$ thick. The most productive shallow aquifer is found in this area of the basin.

\section{Water Quality}

Synoptic collections of water samples were made at two long-term and five short-term streamwater sites in the Lower Wills Creek basin, as listed in the table on the next page. Ground-water samples were collected at four sites near the town of Plainfield, in the northwestern part of the basin (fig. 12).

Wills Creek Dam, which forms Wills Creek Reservoir, is near the downstream end of Wills Creek about $6 \mathrm{mi}$ above the confluence of Wills Creek with the Muskingum River. Elsewhere in the basin, Wills Creek is a rather sluggish stream despite the discharge that it receives from Upper Wills Creek basin. Neither the USGS gaging station at Cambridge nor the gaging station below Wills Creek Dam are suitable as long-term sampling sites for this investigation because Wills Creek is a composite of drainage from various sources. Instead, the drainage carried by Crooked Creek and White Eyes Creek, on which the long-term sites were established (sites L-1 and L-2), is more representative of baseline conditions in the basin than what might be derived from water-quality analyses of the main stem.

The five short-term sites were spaced throughout the basin to assess streamwater quality of active mining areas north of Plainfield and to provide coverage of the remainder of the basin. Small areas of mining 


\section{Streamwater}

The following streamwater sites were sampled in mid-October 1989. Their locations are shown in figure 12.

\begin{tabular}{cclc}
$\begin{array}{c}\text { Map index } \\
\text { number }\end{array}$ & Site type & \multicolumn{1}{c}{ Site name } & $\begin{array}{c}\text { Drainage area } \\
\text { (square miles) }\end{array}$ \\
\hline & & & \\
L-1 & Long term & Crooked C nr Cambridge & 42.5 \\
L-2 & do. & White Eyes C nr Plainfield & 51.7 \\
L-3 & Short term & Bacon Rn nr Plainfield & 14.5 \\
L-4 & do. & Birds Rn at Birds Run & 31.0 \\
L-5 & do. & Salt F nr Middlebourne & 24.5 \\
L-6 & do. & Clear F nr Birmingham & 11.2 \\
L-7 & do. & Sugartree C nr Birmingham & 14.9 \\
\hline
\end{tabular}

are located near headwaters of streams that drain to Salt Fork. The forming of Salt Fork Reservoir has reduced the gradient of the downstream part of its tributaries such that it was necessary to go some distance upstream in order to sample at a free-flowing site. Waterquality data for the seven streamwater sites in Lower Wills Creek basin are given in table 7. Water from sites L-2, L-3, and L-5 had dissolved-sulfate concentrations greater than $300 \mathrm{mg} / \mathrm{L}$. Water from these sites had the highest specific conductances, ranging from 880 to $1,050 \mu \mathrm{S} / \mathrm{cm}$. For all samples, $\mathrm{pH}$ was in the alkaline range; the median $\mathrm{pH}$ was 7.6 (table 8). Box plots of concentrations for selected water-quality constituents included few outside values and no detached values (fig. 13). In general, the high concentrations of sulfate, manganese, iron, and aluminum and the low $\mathrm{pH}$ associated with acid mine drainage were not found in the samples from Lower Wills Creek basin.

\section{Ground water}

Four wells that yield from unconsolidated deposits were sampled near the village of Plainfield. Two of the sites, Cs-150 and Cs-151, were along streams that drain the most active coal-producing areas of the basin.

Water-quality data for four ground-water sites sampled in September 1989 are given in table 9. Values for $\mathrm{pH}$ ranged from 7.0 to 7.8. Concentrations of total and dissolved iron were high at sites Cs-149, Cs-150, and Cs-151 and ranged from 1,400 to $5,000 \mu \mathrm{g} / \mathrm{L}$. Concentrations of dissolved sulfate and total recoverable and dissolved manganese and aluminum, commonly associated with acid mine drainage, were not high.

Stiff diagrams (fig. 12) show that calcium was the dominant cation except in well Cs-151, where magnesium and calcium were principal cations. Bicarbonate was the dominant anion except in well Cs-152, where both bicarbonate and sulfate were principal anions. 
The OEPA standards for public supplies for dissolved iron $(300 \mu \mathrm{g} / \mathrm{L})$ and manganese $(50 \mu \mathrm{g} / \mathrm{L})$ were exceeded in samples from three of the wells, Cs-149, Cs-151, and Cs-150. The water from well Cs-152 met all OEPA standards for constituents analyzed. The waters were moderately hard (Cs-150), hard (Cs-149, Cs-152), and very hard (Cs-151).

\section{Upper Hocking River Basin}

The Upper Hocking River basin, with a drainage area of $465 \mathrm{mi}^{2}$, covers approximately the southeastern two-thirds of Fairfield County, the western third of Perry County, and the northern edge of Hocking County (fig. 1, basin $\mathrm{P}$ ). The area includes all drainage to the Hocking River at and including Harper Run just west of Logan (fig. 14).

As the principal stream, the Hocking River begins at the northwestern corner of the basin (fig. 14) and flows about $32 \mathrm{mi}$ across the western half of the basin to the point where it becomes the upper end of the Middle Hocking River basin (figs. 1 and 24). Two principal tributaries are Clear Creek, which drains the southwestern end of the basin, and Rush Creek and its tributaries, which drain the eastern twothirds of the basin.

Pleistocene glacial advances covered about four-fifths of the Upper Hocking River basin (fig. 14). The limit of glacial advance marks the division between the Glaciated and Unglaciated Allegheny Plateau Sections of the Appalachian Plateaus Physiographic Province. Of the two major glacial advances recognized in the area (Goldthwait and others, 1961), the last major advance (Wisconsinan) did not extend as far as the earlier (Illinoian) advance. The Illinoian surface is thus exposed in a zone 2 to $10 \mathrm{mi}$ wide across the Upper Hocking River basin. In the rugged, thoroughly dissected upland that rises above the Hocking River valley in the unglaciated section, local relief is as great as $350 \mathrm{ft}$.
In contrast, local relief is only minor in Wisconsinan glaciation. Within the zone where Illinoian drift is exposed, modification by post-glacial erosion has left a land surface that is more rugged than the Wisconsinandrift-covered surface but less rugged than the unglaciated terrain along the southern edge of the basin.

\section{Geologic Setting}

From west to east, rock units underlying the Upper Hocking River basin range from undifferentiated Mississippian to Middle Pennsylvanian in age. Lithology of the undifferentiated Mississippian rocks, which underlie most of the basin, is generalized in figure 4 . Principal units that are used for water supplies, in ascending order, include the Berea Sandstone and sandstones and shaly sandstones of the Cuyahoga and Logan Formations.

One of the more important of these aquifers is the Black Hand Sandstone Member of the Cuyahoga Formation. Although the Mississippian aquifer units are not closely associated with coal mining, the Black Hand Sandstone has been described as a useful source of water below coal-bearing strata in parts of the subject and adjacent basins where surface mining has become increasingly active (Norris and Mayer, 1982).

Small sections of the Pottsville Formation underlie the Upper Hocking River basin in eastern Fairfield County. Although coal is present, Brant and Delong's assessment study (1960) attaches little importance to Pottsville coals in the area. Equivalents of the conglomeratic sandstone aquifers at the base of the Pottsville Formation in northeastern Ohio are not present in the Upper Hocking River basin. Much of the Pottsville is above the water table as determined from water levels of perennial streams; but, toward the 
Table 7. Water-quality data for streamwater sites in Lower Wills Creek basin, October 1989

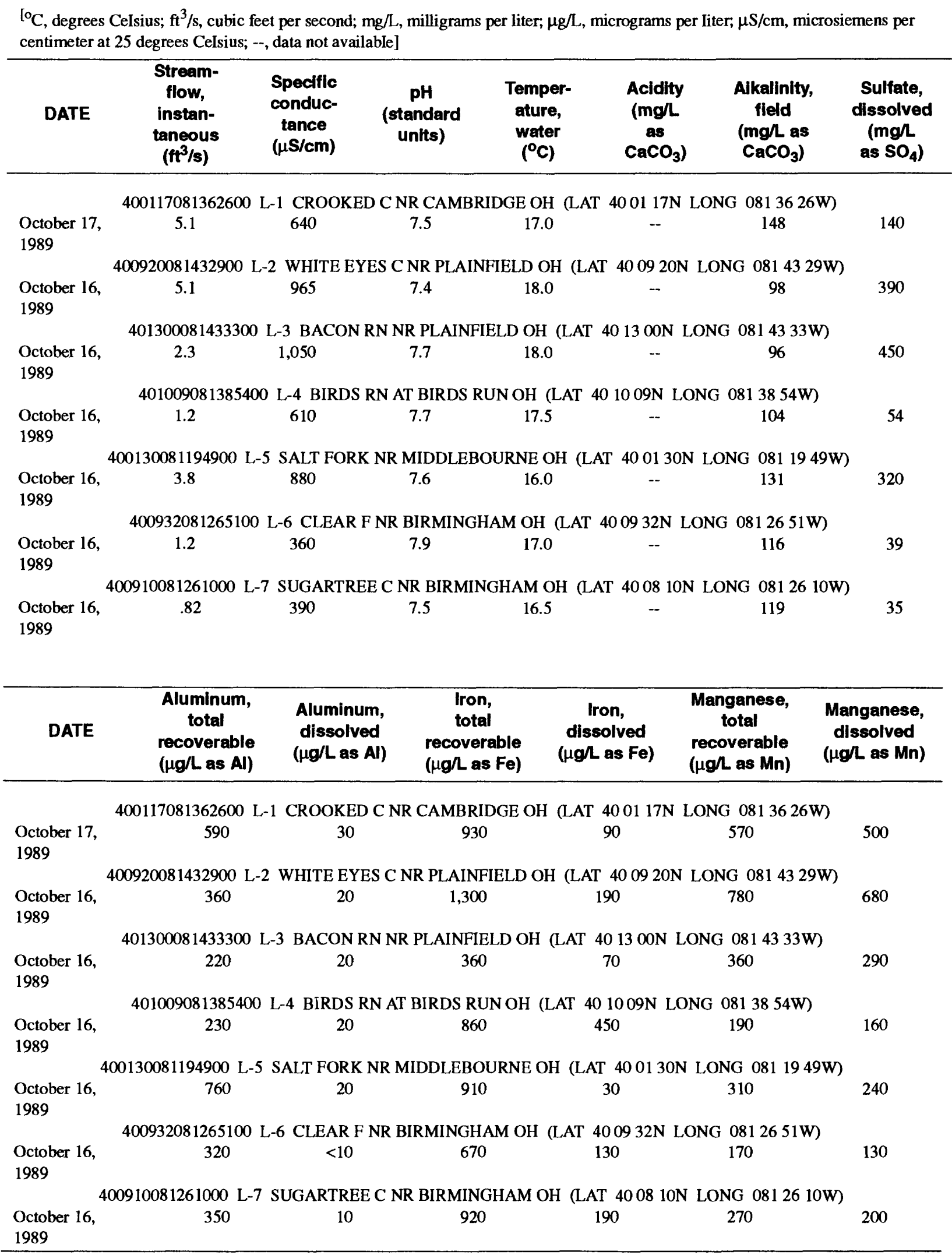


Table 8. Ranges and medians for selected water-quality characteristics for streamwater sites in Lower Wills Creek basin, October 1989

[mg/L, milligrams per liter; $\mu \mathrm{g} / \mathrm{L}$, micrograms per liter; $\mu \mathrm{S} / \mathrm{cm}$, microsiemens per centimeter at 25 degrees Celsius]

Property or

Locations $^{a}$

constituent

Range

(fig. 12)

Median

Specific conductance,

$$
\text { in } \mu \mathrm{S} / \mathrm{cm} \text {-...-...... }
$$

$\mathrm{pH}-$

Alkalinity, in $\mathrm{mg} / \mathrm{L}$

$$
\text { as } \mathrm{CaCO}_{3}
$$

Sulfate, dissolved, in $\mathrm{mg} / \mathrm{L}$ as $\mathrm{SO}_{4}$

Aluminum, total, in $\mu \mathrm{g} / \mathrm{L}$ as $\mathrm{Al}---\cdots-$

Aluminum, dissolved, in $\mu \mathrm{g} / \mathrm{L}$ as $\mathrm{A} 1$-......

Iron, total, in $\mu \mathrm{g} / \mathrm{L}$ as $\mathrm{Fe}$-...-.--

Iron, dissolved,

$$
\text { in } \mu \mathrm{g} / \mathrm{L} \text { as } \mathrm{Fe}-\cdots-
$$

Manganese, total, in $\mu \mathrm{g} / \mathrm{L}$ as $\mathrm{Mn}-.-$

Manganese, dissolved, in $\mu \mathrm{g} / \mathrm{L}$ as $\mathrm{Mn}$--.----

360 to 1,050

7.4 to 7.9

96 to 148

35 to 450

220 to 760

$<10$ to 30

360 to 1,300

30 to 450

170 to 780

130 to 680
L-6; L-3

L-2; L-6

L-3; L-1

L-7; L-3

L-3; L-5

L-6; L-1

L-3; L-2

$\mathrm{L}-5 ; \mathrm{L}-4$

L-6; L-2

L-6; L-2
640

7.6

$\mathrm{b}_{116}$

140

350

20

910

130

310

240

a Sites at which the minimum values in the ranges were measured are to the left of the semicolon. Sites at which the maximum values in the ranges were measured are to the right of the semicolon.

b Median was calculated on the basis of only those samples for which alkalinity could be measured (see "Methods," p. 14). 


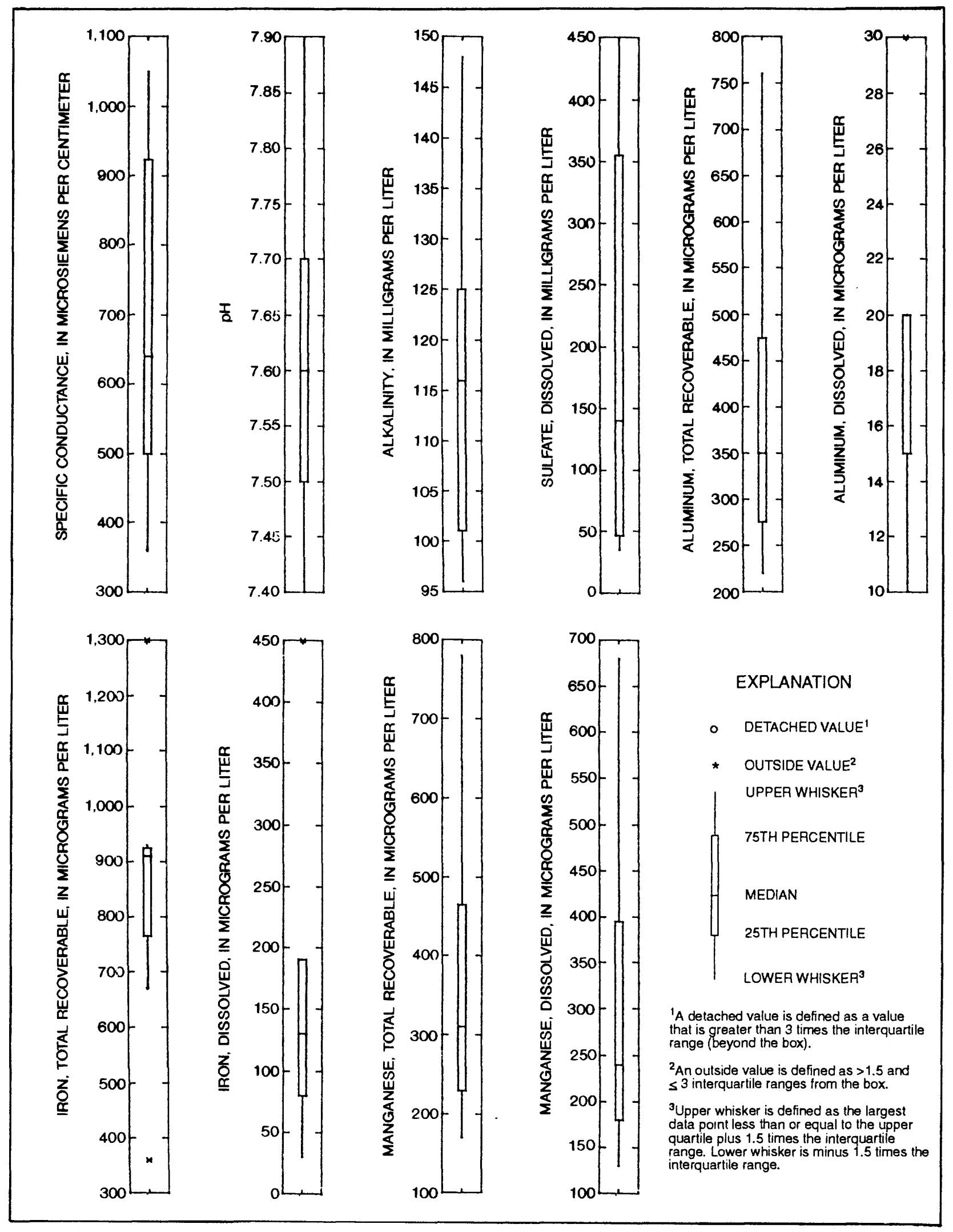

Figure 13.--Ranges, percentiles, and medians of constituents at seven streamwater sites in the Lower Wills Creek basin. 


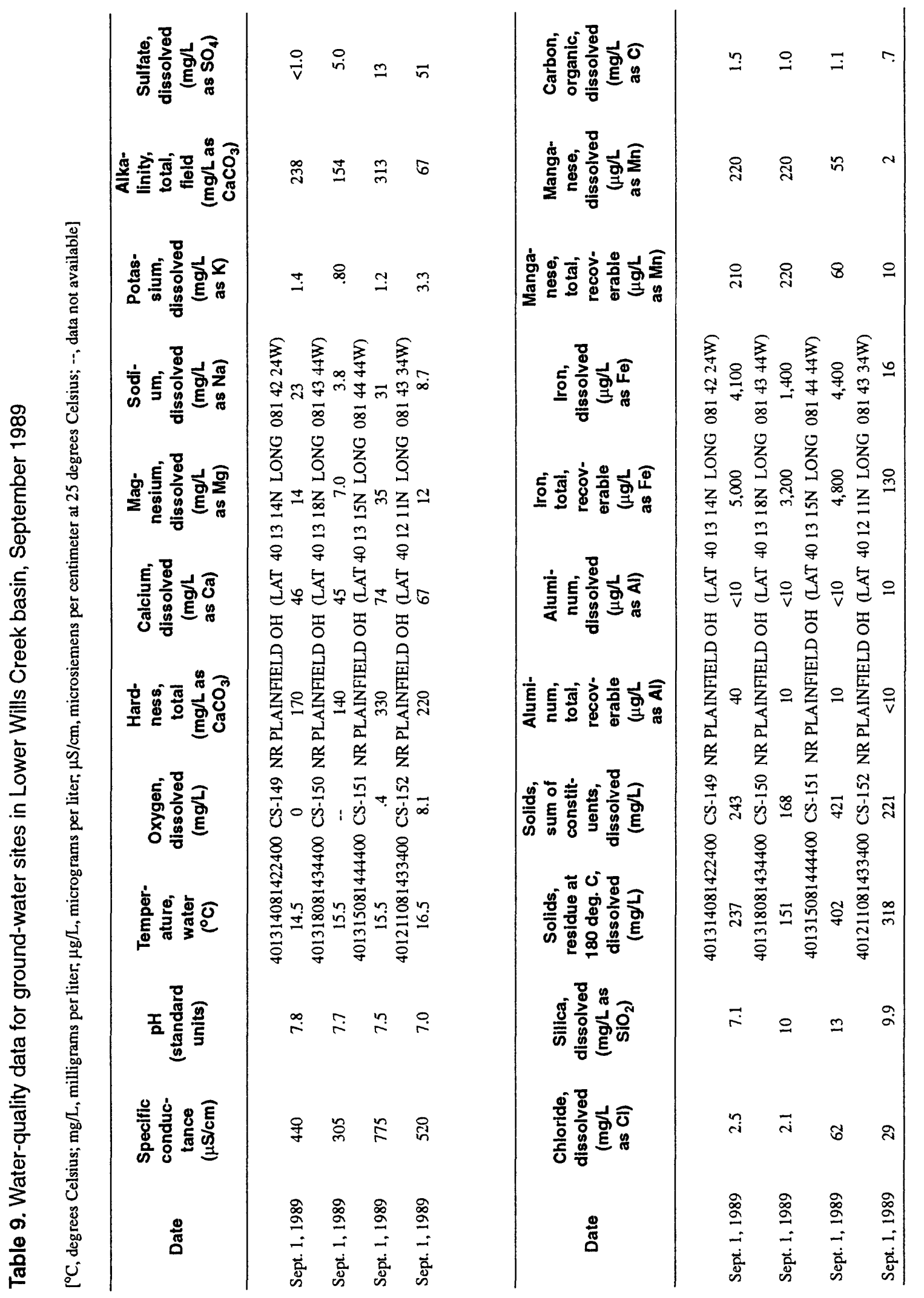




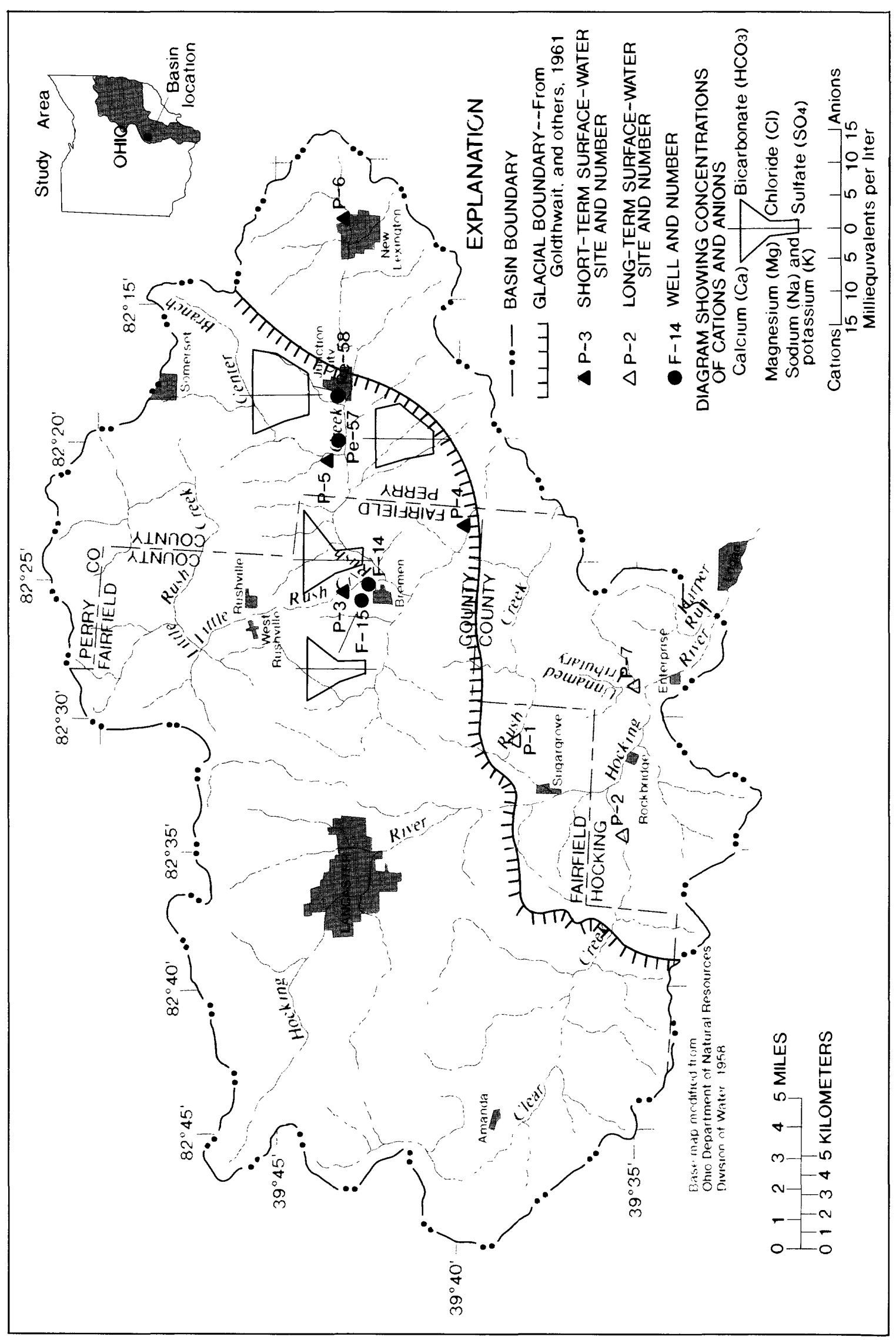

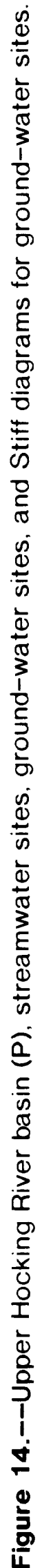


eastern side of the basin, the Massillon Sandstone Member (Connoquenessing Sandstone, Member of Pottsville Formation,USGS usage) is available in the subsurface as a water-supply source (Stout and others, 1943).

Scattered remnants of the Allegheny Formation, which underlie the eastern part of the basin, are important as a source of coal (individual coal units are identified in fig. 4). Several permits for surface mining of the Middle Kittanning (No. 6) coal have been issued, but, as of 1989, the No. 6 coal was being mined at only one location along the drainage divide between the Upper and Middle Hocking River basins (fig. 1, basins P and Q). Basal remnants of the Conemaugh Formation are present but only at high elevations along the eastern margin of the basin.

\section{Water Quality}

Two long-term sites and five short-term sites were chosen to assess streamwater quality in the Upper Hocking River basin. Four ground-water sites selected for sampling were along the course of Rush Creek.

The streamwater sites in the table on the next page were sampled in mid-October 1989. Their locations are shown in figure 14.

The drainage network of the Upper Hocking River basin is more complex than that of other basins studied in this investigation, at least with respect to the Rush Creek tributary network. Long-term site P-1 is located on the Rush Creek tributary network that drains the eastern half of the basin, the area in which all of the coal deposits and mining activity in the basin are found. In contrast, long-term site P-2 is on a stream draining an area devoid of coal.

Coal-bearing strata are present near the headwaters of each of the five short-term sites that were used in the synoptic sampling.

Site P-7 was chosen to measure a small watershed that drains directly to the Hocking River. Sites P-3, P-4, and P-5 were selected to mea- sure the larger tributaries to Rush Creek. Site P-6 was selected to measure the upper drainage area of Rush Creek.

Results of the analyses of water samples show that water quality at site P-6 was substantially different from water quality at the other sites sampled (table 10). Water at this site was strongly acidic $(\mathrm{pH}=2.7)$, whereas $\mathrm{pH}$ at the other six sites was in the alkaline range. Water from site P-6 had high concentrations of dissolved sulfate and total recoverable and dissolved aluminum, iron, and manganese. Concentrations of total recoverable and dissolved iron were especially high $(170,000$ and $220,000 \mu \mathrm{g} / \mathrm{L})$. The concentration of dissolved manganese in water from site P-1 also was high $(1,300 \mu \mathrm{g} / \mathrm{L})$ but was still well below the dissolved-manganese concentration in water from site P-6 $(21,000 \mu \mathrm{g} / \mathrm{L})$. At site P-6, constituent concentrations were at ot near the maximum, except for $\mathrm{pH}$ and alkalinity (table 11). As shown in figure 15, all of the detached and outside values were from data collected at site P-6, except for a low specific conductance at site P-7.

Water from site P-6 had low $\mathrm{pH}$ and high concentrations of the constituents associated with acid mine drainage. The Allegheny Formation, in the eastern part of the basin where site $\mathrm{P}-6$ is located, is composed of few carbonates, which can buffer $\mathrm{pH}$. Site P-1 is in an area of active mining; however, the water at this site was alkaline, and, except for totalrecoverable and dissolved-manganese concentrations, was not high in constituents associated with acid mine drainage. This absence of symptons of acid mine drainage at site P-1 may be due to the effects of dilution and the buffering of streams in this area by the Maxville Limestone of Mississippian age. 


\begin{tabular}{lclc}
\hline $\begin{array}{c}\text { Map index } \\
\text { number }\end{array}$ & Site type & Site name & $\begin{array}{c}\text { Drainage area } \\
\text { (square miles) }\end{array}$ \\
\hline & & & \\
P-1 & Long term & Rush C nr Sugar Grove & 229.0 \\
P-2 & do. & Clear C nr Rockbridge & 89.0 \\
P-3 & Short term & L Rush C nr Bremen & 97.0 \\
P-4 & do. & Turkey Rn nr Bremen & 7.3 \\
P-5 & do. & Center B Rush C nr & 24.9 \\
P-6 & Junction City & 9.4 \\
P-7 & do. & Rush C at New Lexington & 7. \\
& do. & Unnamed Tr Hocking R & \\
\hline
\end{tabular}

\section{Ground water}

Four ground-water sites along the course of Rush Creek, between Junction City and Bremen, were selected for sampling. The underlying unconsolidated materials in this area constitute a shallow, productive aquifer within which ground-water movement is normally toward Rush Creek. Susceptibility of the aquifer to the effects of mining could result from the spreading of highly degraded streamwater during flood stages or by infiltration induced by a pumping well close to the stream.

Water-quality data for four ground-water sites sampled in September 1989 are given in table 12. Values for $\mathrm{pH}$ ranged from 7.3 to 7.7 , and concentrations of total recoverable and dissolved iron were greater than $1,000 \mu \mathrm{g} / \mathrm{L}$ at sites F-14, Pe-57, and Pe-58.
Stiff diagrams (fig. 14) show that wells F-14 and F-15 are calcium bicarbonate-type waters. Stiff diagrams for wells Pe-57 and Pe-58 show the highly mineralized character of these waters; calcium and magnesium are major cations, and bicarbonate and chloride are major anions. All four wells contain very hard waters.

The OEPA water-quality standards for chloride and sulfate were not exceeded in waters from any of the wells; however, waterquality standards for dissolved iron $(300 \mu \mathrm{g} / \mathrm{L})$ were exceeded at wells F-14, Pe-57, and Pe-58. Water-quality standards for manganese $(50 \mu \mathrm{g} / \mathrm{L})$ were exceeded at wells F-14, F-15, and Pe-58. Water from well Pe-58, a publicwater supply, also exceeded the water-quality standards for dissolved solids $(500 \mathrm{mg} / \mathrm{L})$. 
Table 10. Water-quality data for streamwater sites in Upper Hocking River basin, October 1989

$\left[{ }^{\circ} \mathrm{C}\right.$, degrees Celsius; $\mathrm{ft}^{3} / \mathrm{s}$, cubic feet per second; mg/L, milligrams per liter; $\mu \mathrm{g} / \mathrm{L}$, micrograms per liter; $\mu \mathrm{S} / \mathrm{cm}$, microsiemens per centimeter at 25 degrees Celsius; --, data not available]

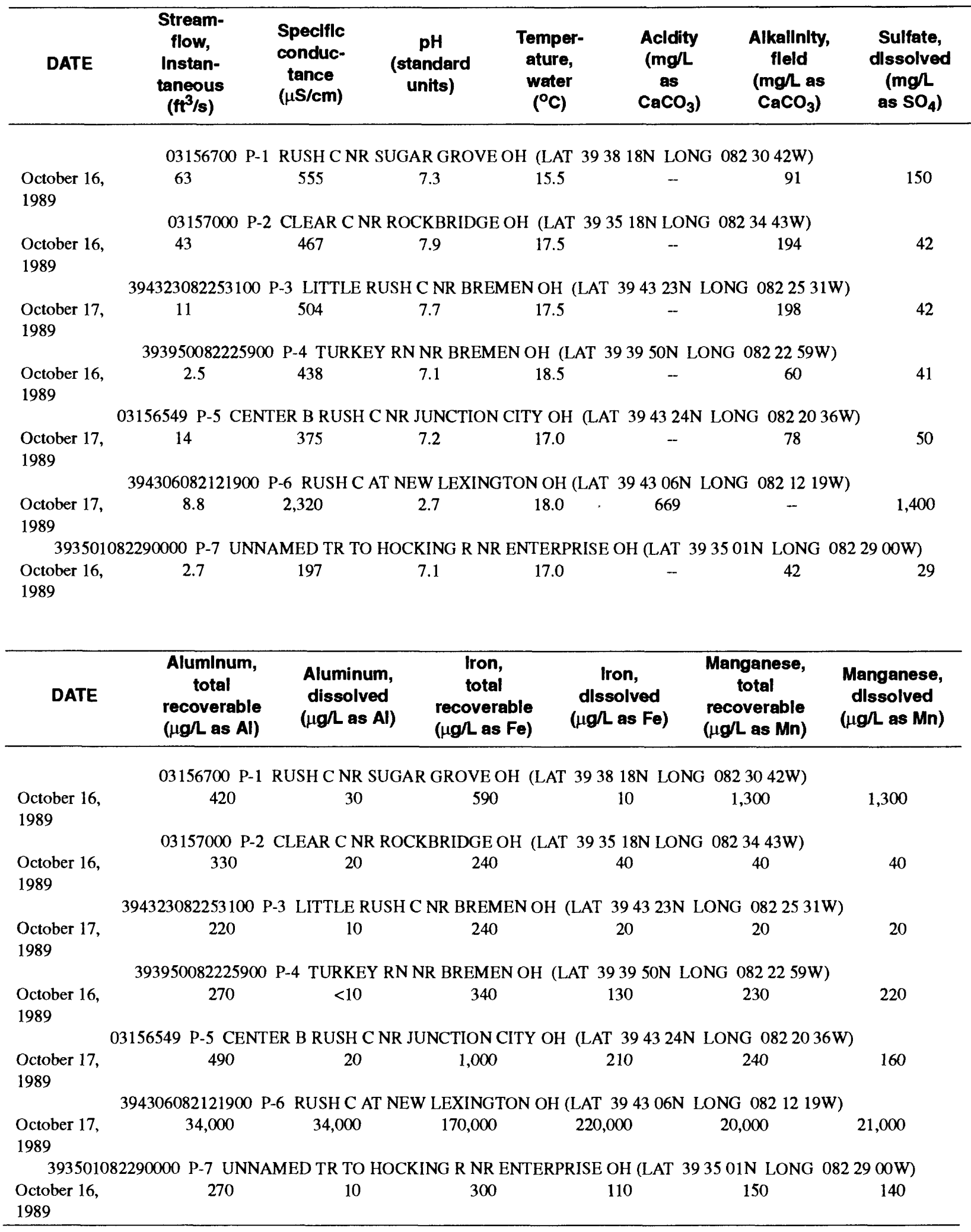


Table 11. Ranges and medians for selected water-quality characteristics for streamwater sites in Upper Hocking River basin, October 1989

[mg/L, milligrams per liter; $\mu \mathrm{g} / \mathrm{L}$, micrograms per liter, $\mu \mathrm{S} / \mathrm{cm}$, microsiemens per centimeter at 25 degrees Celsius]

\begin{tabular}{|c|c|c|c|}
\hline $\begin{array}{l}\text { Property or } \\
\text { constituent }\end{array}$ & Range & $\begin{array}{l}\text { Locations }^{a} \\
\text { (fig. 14) }\end{array}$ & Median \\
\hline $\begin{array}{l}\text { Specific conductance, } \\
\quad \text { in } \mu \mathrm{S} / \mathrm{cm}\end{array}$ & $\begin{array}{l}197 \text { to } 2,320 \\
2.7 \text { to } 7.9\end{array}$ & $\begin{array}{l}\text { P-7; P-6 } \\
\text { P-6; P-2 }\end{array}$ & $\begin{array}{l}467 \\
7.2\end{array}$ \\
\hline $\begin{array}{l}\text { Alkalinity, in } \mathrm{mg} / \mathrm{L} \\
\text { as } \mathrm{CaCO}_{3}\end{array}$ & 42 to 198 & P-7; P-3 & b84 \\
\hline $\begin{array}{l}\text { Sulfate, dissolved, } \\
\text { in } \mathrm{mg} / \mathrm{L} \text { as } \mathrm{SO}_{4} \\
\text { Aluminum, total. }\end{array}$ & 29 to 1,400 & P-7; P-6 & 42 \\
\hline in $\mu \mathrm{g} / \mathrm{L}$ as $\mathrm{Al}$ & 220 to 34,000 & P-3; P-6 & 270 \\
\hline $\begin{array}{l}\text { Aluminum, dissolved, } \\
\text { in } \mu \mathrm{g} / \mathrm{L} \text { as } \mathrm{A} 1 \text { - }\end{array}$ & $<10$ to 34,000 & P-4; P-6 & 20 \\
\hline $\begin{array}{l}\text { Iron, total, } \\
\quad \text { in } \mu \mathrm{g} / \mathrm{L} \text { as } \mathrm{Fe}-\end{array}$ & 240 to 170,000 & P-2, 3; P-6 & 340 \\
\hline $\begin{array}{l}\text { Iron, dissolved, } \\
\quad \text { in } \mu \mathrm{g} / \mathrm{L} \text { as } \mathrm{Fe}-\end{array}$ & 10 to 220,000 & P-1; P-6 & 110 \\
\hline $\begin{array}{l}\text { Manganese, total, } \\
\text { in } \mu \mathrm{g} / \mathrm{L} \text { as } \mathrm{Mn}-\cdots- \\
\text { Manganese, dissolved, } \\
\text { in } \mu \mathrm{g} / \mathrm{L} \text { as } \mathrm{Mn}-\ldots .\end{array}$ & 20 to 20,000 & P-3; P-6 & 230 \\
\hline
\end{tabular}

a Sites at which the minimum values in the ranges were measured are to the left of the semicolon. Sites at which the maximum values in the ranges were measured are to the right of the semicolon.

b Median was calculated on the basis of only those samples for which alkalinity could be measured (see "Methods," p. 14). 


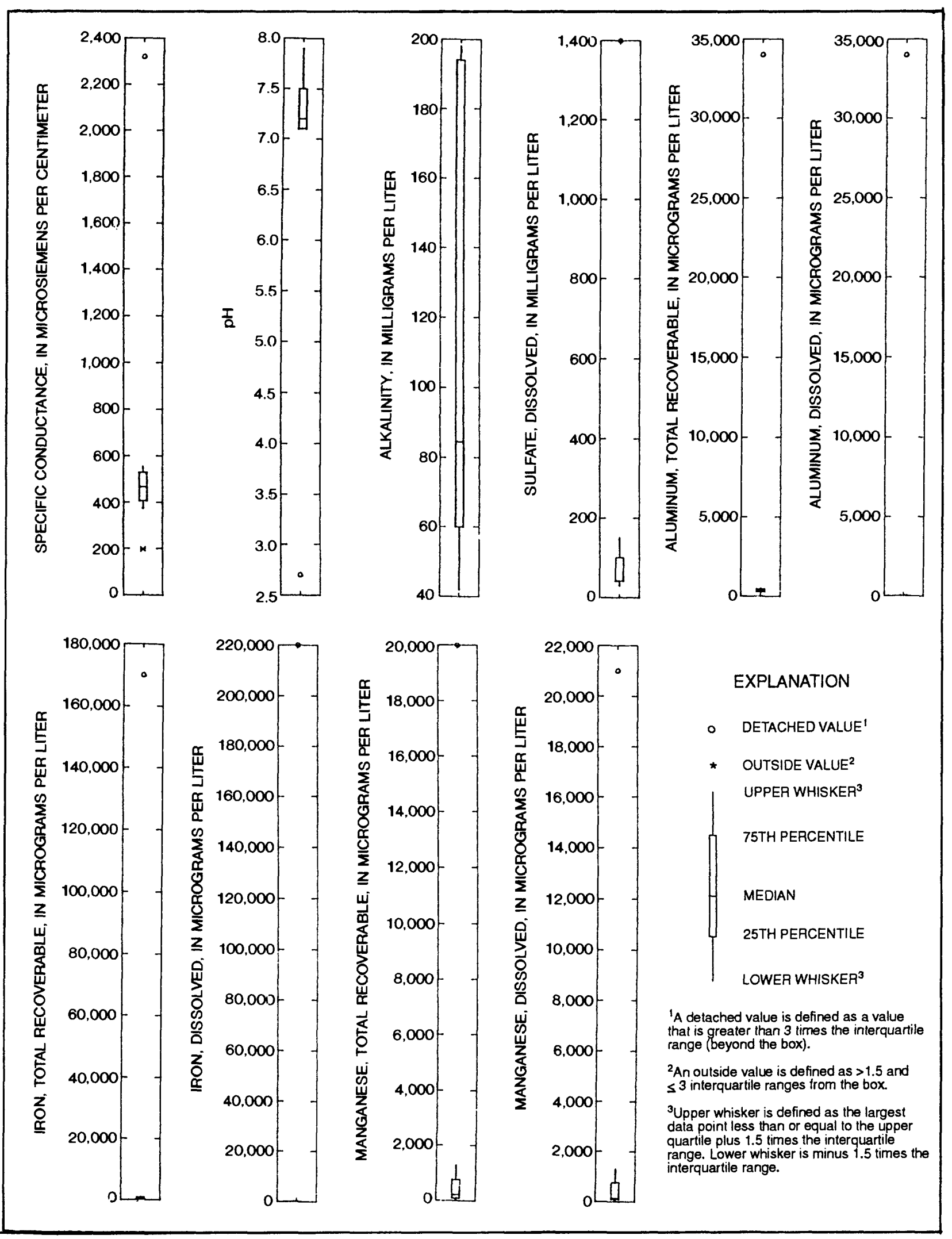

Figure 15.--Ranges, percentiles, and medians of constituents at seven streamwater sites in the Upper Hocking River basin. 


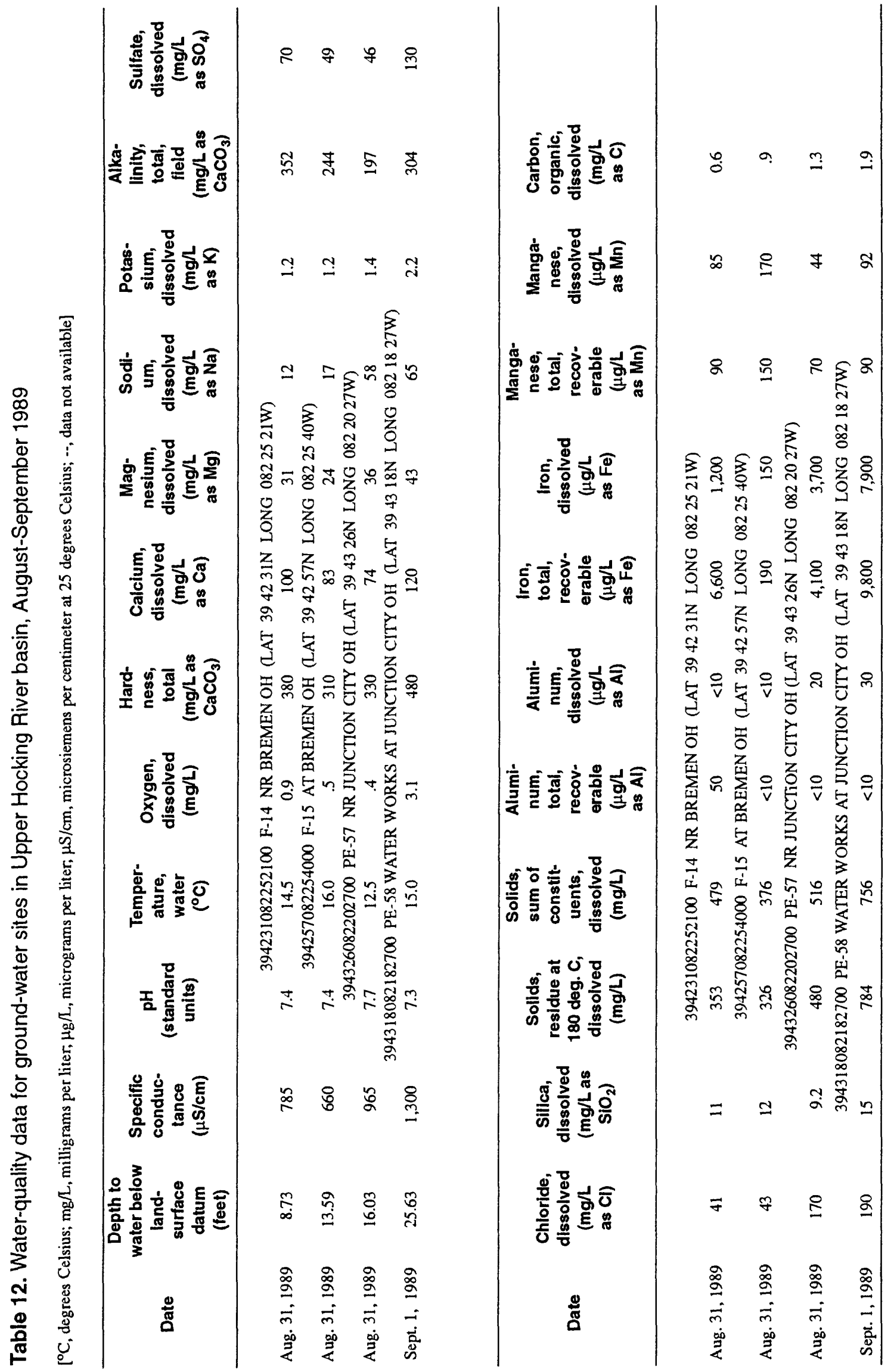




\section{Yellow and Cross Creeks Basin}

The Yellow and Cross Creeks basin (fig. 1, basin B), with a drainage area of $439 \mathrm{mi}^{2}$, is a combination of three subbasins that drain to the Ohio River (fig. 16). In the north, the Yellow Creek subbasin includes the northern third of Jefferson County and extends into the eastern part of Carroll County and the southwestern corner of Columbiana County.

Streamwater sites B-1, B-4, and B-5 are in the Yellow Creek subbasin. To the south, the central third of Jefferson County and the northeastern corner of Harrison County form the Short Creek subbasin, which contains streamwater sites B-2 and B-3. The northeastern part of Jefferson County contains a $70-\mathrm{mi}^{2}$ unnamed area between Mingo Junction, Richmond, and Stratton that is drained by sevral short streams that discharge directly to the Ohio River. Streamwater sites B-6, B-7, and B- 8 are in the unnamed subbasin.

The limit of glaciation is less than $10 \mathrm{mi}$ to the north of the Yellow and Cross Creeks basin. Thus, the basin lies entirely within the unglaciated Allegheny Plateau Section of the Appalachian Plateaus Physiographic Province. In general, the terrain is characterized by a thoroughly dissected upland surface; in places, however, the upland consists of broad, relatively flat surfaces that give way abruptly to numerous steep-sided valleys with narrow bottoms. Local relief near the Ohio River valley is as great as $500 \mathrm{ft}$.

\section{Goologic Setting}

Stratigraphic units present, in ascending order, are the Allegheny, Conemaugh, and Monongahela Formations of Pennsylvanian age. The Conemaugh Formation, which is mostly devoid of mineable coal, forms much of the land surface in the study basin.

Structurally, the rocks dip southward to southeastward across the Yellow and Cross Creeks basin. In the northern part of Jefferson County and nearby parts of Columbiana and Carroll Counties, where extensive erosion has produced several deep valleys, the Allegheny Formation is exposed. Elsewhere, the Monongahela Formation is present as scattered remnants along ridgetops that separate the subbasins described earlier and along the drainage divides to the south and west. As of 1989 (Lopez, 1991), coal from the Allegheny Formation was being mined in the northwestern corner of and along the western border of the study basin with Conotton Creek basin (fig. 1, basin F). In the same general area, a small amount of coal from the Conemaugh Formation also was being mined. By far, most of the coal production in the Yellow and Cross Creeks basin is from the Pittsburgh (No. 8) coal at the base of the Monongahela Formation, mostly in the southern part of the study basin and near Knoxville in Jefferson County (fig. 16). 


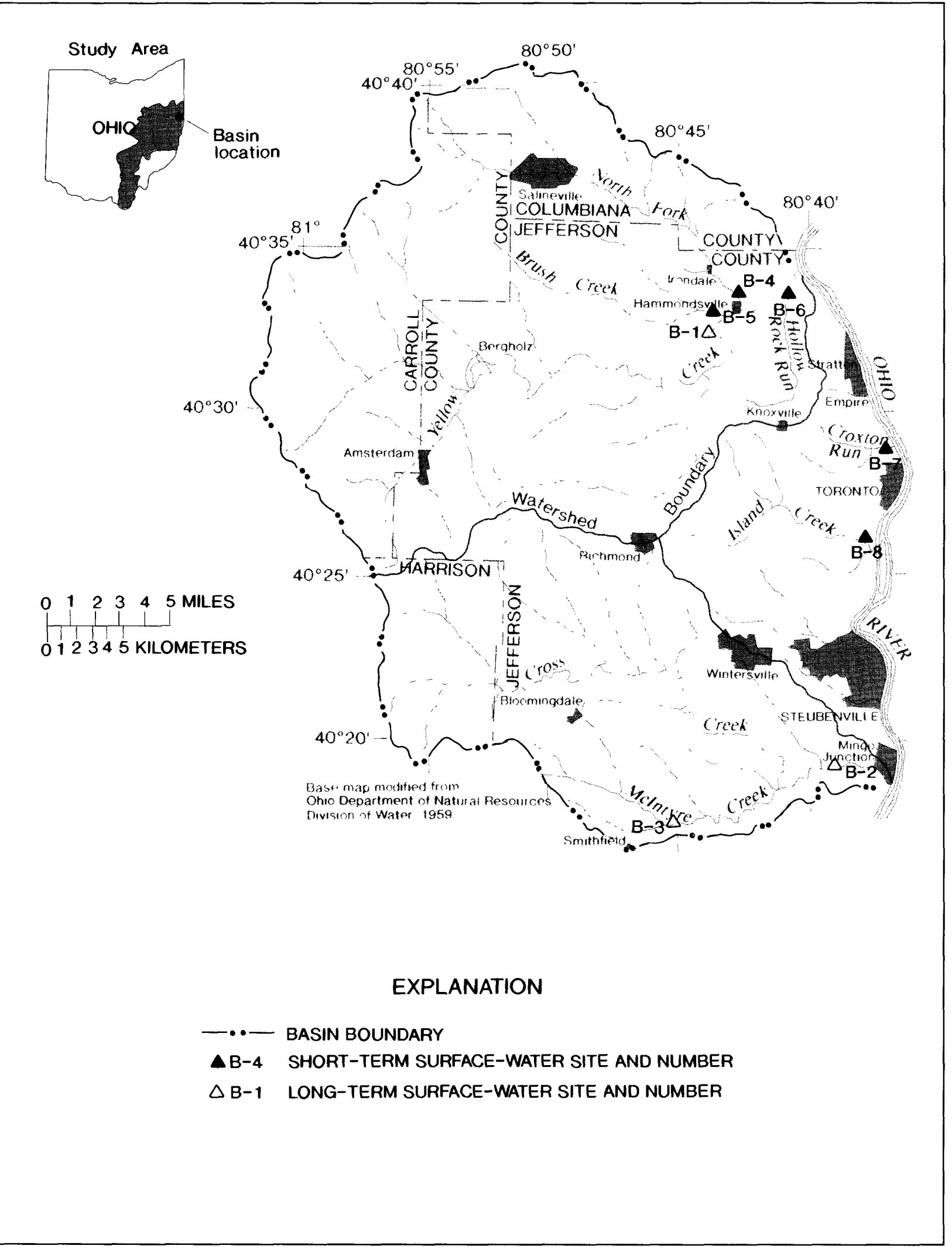

Figure 16.--Yellow and Cross Creeks basin (B) and streamwater sites. 
In many places, the Allegheny Formation is not far below the surface, but, currently (1989), there are no underground mines working in the basin (Lopez, 1991). Topographic maps reveal that much of the land surface has been modified by surface mining in the Yellow and Cross Creeks basin. Judging from the length of the list of pending permits to mine coal (Vanessa Tolliver, Ohio Department of Natural Resources, Division of Reclamation, written commun., 1990), interest in the surface mining of coal in the basin remains high. Most of the permits are to mine the No. 8 coal, but, in the northwest and west, there is substantial interest in the Middle Kittanning (No. 6) and Upper Freeport (No. 7) coals in the Allegheny Formation and the Mahoning (7A) and Harlem (7B), both of which are minor coals in the Conemaugh Formation.

Within the stratigraphic sections described above, localized sources of water are present in sandstones; thin, fractured limestones; and even in coal beds. Although the study basin is populated by many users of these sources, according to ground-water-resource maps published by ODNR for the area (Crowell, 1978, 1980; Schmidt, 1959), well yields are generally less than $2 \mathrm{gal} / \mathrm{min}$. In contrast, sands and gravels of the highly productive Ohio Valley aquifer at the eastern edge of the basin can yield more than $1,000 \mathrm{gal} / \mathrm{min}$ to wells.

\section{Water Quality}

Three long-term and five short-term sites were selected to study streamwater quality in Yellow and Cross Creeks basin. Except for the Ohio River valley aquifer, the Yellow and Cross Creeks basin does not contain a shallow, productive aquifer. Therefore, ground-water quality was not investigated in this basin.

The streamwater sites in the table on the next page were sampled in June 1991. Their locations are shown in figure 16.

Flood-control structures on the Ohio River cause backwater conditions along the downstream reaches of the major tributaries to the
Ohio River. Therefore, the three long-term sites were placed where flow was strong enough for discharge measurements and sampling. Two short-term sites, B-7 and B-8 (fig. 16), were selected to represent water quality in the unnamed area of streams draining directly to the Ohio River. Site B-8 was near the lower end of Island Creek, the largest stream in the unnamed drainage area.

Sites B-4, B-5, and B-6 were placed to assess water quality in streams draining the northern part of the study basin.

Water-quality data for surface-water sites show that specific conductance was greater than $1,000 \mu \mathrm{S} / \mathrm{cm}$ in samples from sites $\mathrm{B}-2$, B-3, B-6, B-7, and B-8 (table 13). The median specific conductance for all sites within the basin was $1,025 \mu \mathrm{S} / \mathrm{cm}$ (table 14). Water from sites B-2, B-3, B-6, and B-7 had high dissolved-sulfate concentrations (greater than $250 \mathrm{mg} / \mathrm{L}$ ), and among four sites, water from site B-3 had the highest dissolved-sulfate concentration $(1,200 \mathrm{mg} / \mathrm{L})$. None of the concentrations of total recoverable and dissolved iron, aluminum, or manganese were excessively high except at site B-7, where the concentration of total recoverable iron was greater than $1,000 \mathrm{ug} / \mathrm{L}$. Values for $\mathrm{pH}$ were in the alkaline range; the median was 8.0. Except for one detached value each for total recoverable and dissolved manganese, all of the values of constituents at surface-water sites were within the interquartile ranges and whiskers (fig. 17).

Therefore, although the concentrations of sulfate and iron were high enough at some sites to be indicative of acid mine drainage, alkaline $\mathrm{pH}$ may indicate buffering of streamwaters. The area is underlain by Upper Pennsylvanian units that are more calcareous than those in western reaches of the basin and that may have buffered the acidity of the streams. 


\begin{tabular}{lclr}
$\begin{array}{c}\text { Map index } \\
\text { number }\end{array}$ & Site type & \multicolumn{1}{c}{ Site name } & $\begin{array}{c}\text { Drainage area } \\
\text { (square miles) }\end{array}$ \\
\hline & & & \\
B-1 & Long term & Yellow C nr Hammondsville & 147.0 \\
B-2 & do. & Cross C nr Mingo Junction & 118.0 \\
B-3 & do. & McIntyre C nr Smithfield & 14.3 \\
B-4 & Short term & NF Yellow C at Hammondsville & 59.4 \\
B-5 & do. & Brush C at Hammondsville & 15.3 \\
B-6 & do. & Hollow Rock Rn nr Hammondsville & 9.9 \\
B-7 & do. & Croxton Rn at Toronto & 9.0 \\
B-8 & do. & Island C nr Toronto & 22.5 \\
& & & \\
\hline
\end{tabular}

\section{Walhonding River Basin}

The Walhonding River basin drains an area of $449 \mathrm{mi}^{2}$ that includes the north-central part of Coshocton County and the south-central part of Holmes County (fig. 1, basin J). The basin designated in this study as the Walhonding River basin is considered only part of the Walhonding River basin in the Ohio Water Plan Inventory series (Pree, 1962a). The basin receives drainage from the west, where the Mohican River and Kokosing River join to form the Walhonding River (fig. 18). On the north, drainage from the Upper Killbuck basin enters the Walhonding basin along Killbuck Creek just upstream from Paint Creek, about 5 mi north of Millersburg (fig. 18). Killbuck Creek more or less bisects the basin before it joins the Walhonding River; from that point, the Walhonding River flows eastward across the southern part of the basin. About $6 \mathrm{mi}$ further downstream, at the southeastern corner of the basin, the Walhonding River joins the Tuscarawas River at Coshocton, where the system becomes the Muskingum River.

About one-quarter or less of the basin was covered by the Killbuck lobe of the last (Wisconsinan) glaciation. The glacial boundary (fig. 18) also separates the Glaciated
Allegheny Plateau and Unglaciated Allegheny Plateau Sections of the Appalachian Plateaus Physiographic Province.

The nonglaciated, southern three-quarters of the basin is largely a maturely dissected upland, where local relief is as great as $300 \mathrm{ft}$. The Walhonding River has cut a fairly wide valley in which the present-day stream follows a meandering path. In its course across the basin, the Walhonding River drops about $80 \mathrm{ft}$ in $21 \mathrm{mi}$. The valley of the lower part of Killbuck Creek has developed a somewhat incised meander through the unglaciated upland. Within the flood plain itself, the present course of Killbuck Creek follows a meandering path. The gradient of Killbuck Creek across the basin is about $2 \mathrm{ft} / \mathrm{mi}$, compared to about $4 \mathrm{ft} / \mathrm{mi}$ for the Walhonding River. Thus, much of Killbuck Creek is very slow moving, and wetland areas along its course are common. Elsewhere in the nonglaciated area, the topography in the smaller valleys is more rugged, and streamflow is faster.

In the north, glaciation has subdued the land surface to varying degrees. Data from representative wells (Crowell, 1979) indicate that the drift is only a few feet thick in places, but many of the valleys contain $150 \mathrm{ft}$ or more of fill. 
Table 13. Water-quality data for streamwater sites in Yellow and Cross Creeks basin, June 1991

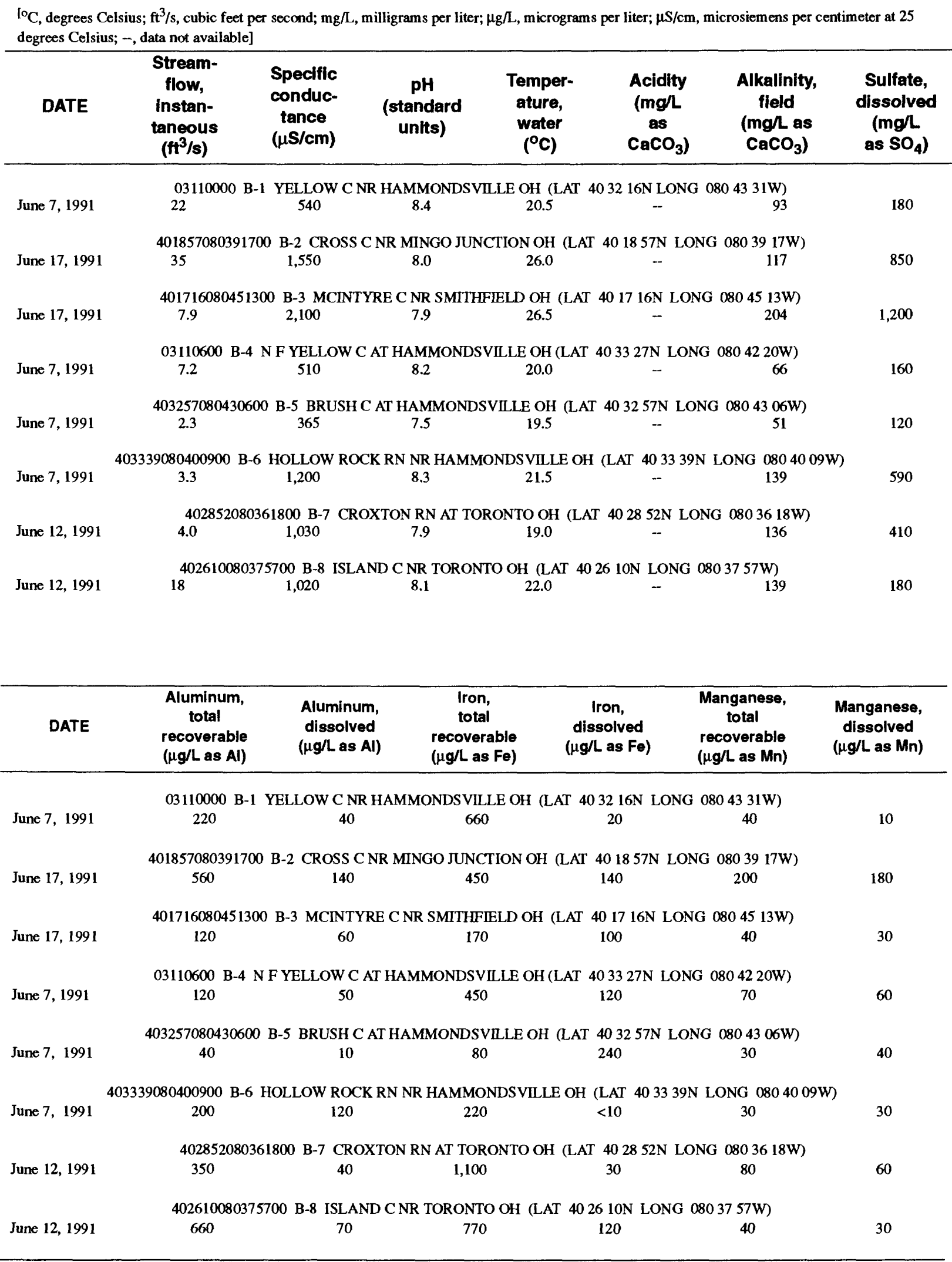


Table 14. Ranges and medians for selected water-quality characteristics for streamwater sites in Yellow and Cross Creeks basin, June 1991

[mg/L, milligrams per liter; $\mu \mathrm{g} / \mathrm{L}$, micrograms per liter; $\mu \mathrm{S} / \mathrm{cm}$, microsiemens per centimeter at 25 degrees Celsius]

\begin{tabular}{|c|c|c|c|}
\hline $\begin{array}{l}\text { Property or } \\
\text { constituent }\end{array}$ & Range & $\begin{array}{l}\text { Locations }^{a} \\
\text { (fig. 16) }\end{array}$ & Median \\
\hline $\begin{array}{l}\text { Specific conductance, } \\
\quad \text { in } \mu \mathrm{S} / \mathrm{cm}-\end{array}$ & $\begin{array}{l}365 \text { to } 2,100 \\
7.5 \text { to } 8.4\end{array}$ & $\begin{array}{l}\text { B-5; B-3 } \\
\text { B-5; B-1 }\end{array}$ & $\begin{array}{r}1,025 \\
8.0\end{array}$ \\
\hline $\begin{array}{l}\text { Alkalinity, in } \mathrm{mg} / \mathrm{L} \\
\text { as } \mathrm{CaCO}_{3}\end{array}$ & 51 to 204 & B-5; B-3 & 127 \\
\hline $\begin{array}{l}\text { Sulfate, dissolved, } \\
\text { in } \mathrm{mg} / \mathrm{L} \text { as } \mathrm{SO}_{4^{----}} \\
\text {Aluminum, total, }\end{array}$ & 120 to 1,200 & B-5; B-3 & 295 \\
\hline in $\mu \mathrm{g} / \mathrm{L}$ as $\mathrm{Al}$ & 40 to 660 & B-5; B-8 & 210 \\
\hline $\begin{array}{l}\text { Aluminum, dissolved, } \\
\text { in } \mu \mathrm{g} / \mathrm{L} \text { as } \mathrm{A} 1 \text { - }\end{array}$ & 10 to 140 & B-5; B-2 & 55 \\
\hline $\begin{array}{l}\text { Iron, total, } \\
\quad \text { in } \mu \mathrm{g} / \mathrm{L} \text { as } \mathrm{Fe}-\end{array}$ & 80 to 1,100 & B-5; B-7 & 450 \\
\hline $\begin{array}{l}\text { Iron, dissolved, } \\
\text { in } \mu \mathrm{g} / \mathrm{L} \text { as } \mathrm{Fe}-\end{array}$ & $<10$ to 240 & B-6; B-5 & 110 \\
\hline 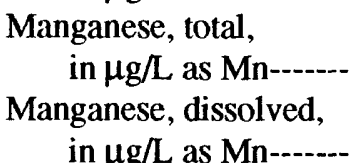 & 30 to 200 & B-5; B-6 & 40 \\
\hline
\end{tabular}

a Sites at which the minimum values in the ranges were measured are to the left of the semicolon. Sites at which the maximum values in the ranges were measured are to the right of the semicolon. 


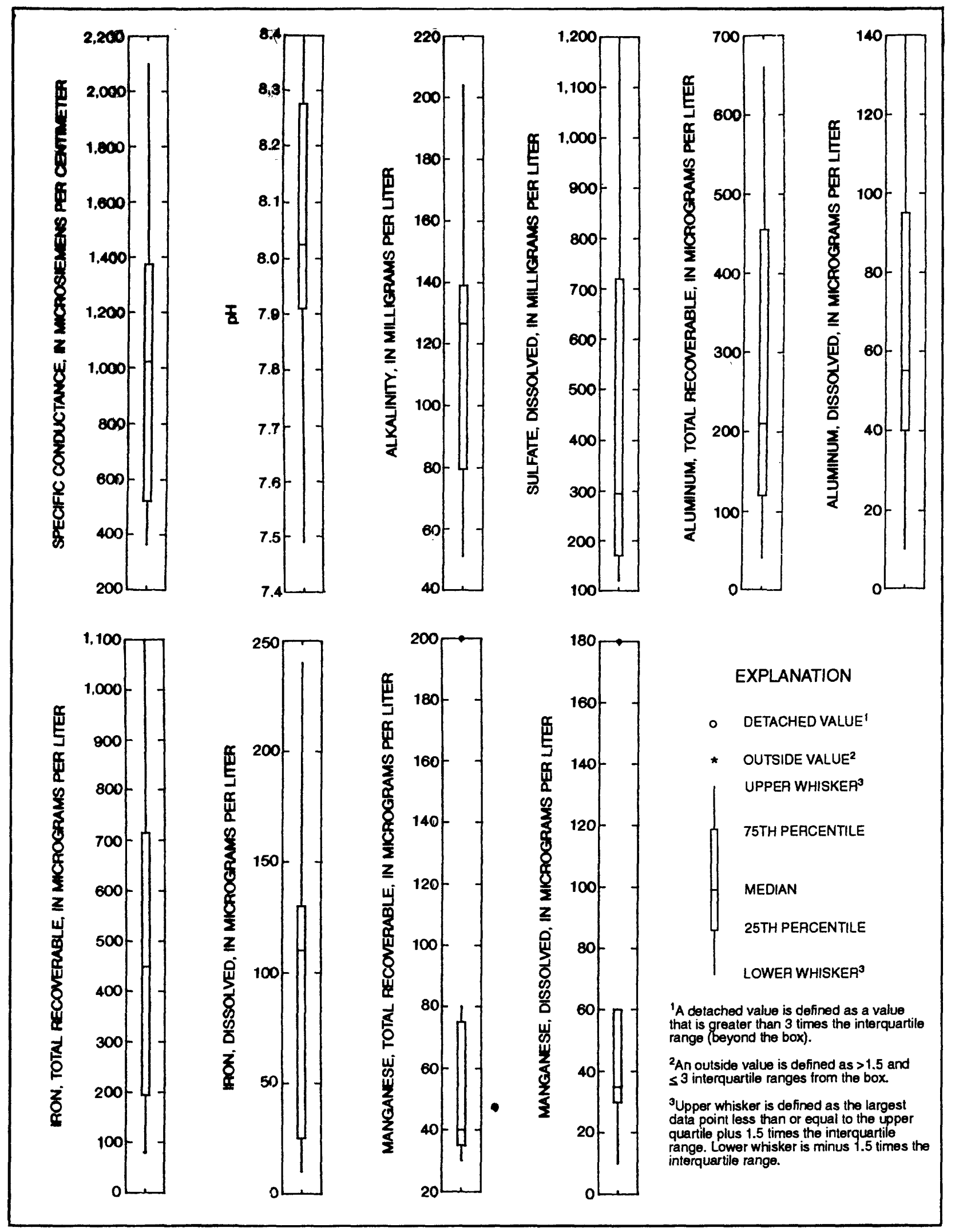

Figure 17.--Ranges, percentiles, and medians of constituents at eight streamwater sites in the Yellow and Cross Creeks basin. 


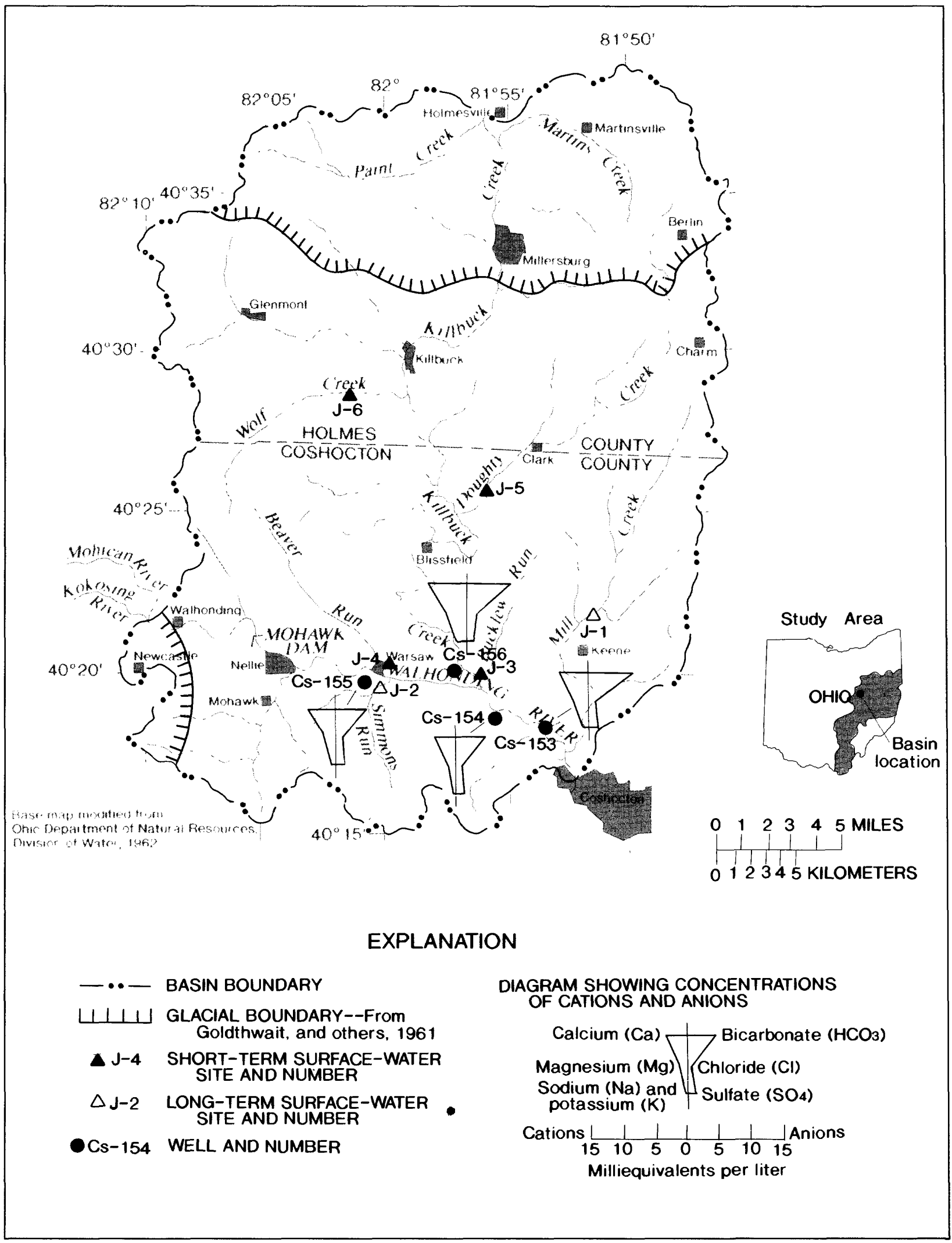

Figure 18.--Walhonding River basin $(\mathrm{J})$, streamwater sites, ground-water sites, and Stiff diagrams for ground-water sites. 


\section{Geologic Setting}

Major bedrock units underlying the basin, in ascending order of age, consist of shales of Mississippian age and sandstones and coalbearing strata of Pennsylvanian age. The oldest unit is the Cuyahoga Formation, of Mississippian age, which lies below a covering of glacial drift in the valley floor of Killbuck Creek at the northern end of the basin. Elsewhere, the overlying Logan Formation (Mississippian) forms many of the valley floors in the nonglaciated area. To the south and east, the stratigraphic section continues upward with the Pottsville, Allegheny, and Conemaugh Formations of Pennsylvanian age (fig. 4). Only small remnants of the Conemaugh are present in the southeastern part of the basin. Structurally, the stratigraphic section shows a gentle eastward regional dip.

Most of the coal produced in the basin is from the Allegheny Formation, which is present in patches over much of the area. On the basis of information given by Lopez (1991), the Lower Kittanning (No. 5) and the Middle Kittanning (No. 6) coals are the principal units being mined. Other Allegheny units being mined include the Brookville (No. 4) and the Strasburg (No. 5A). The Upper Freeport (No. 7) coal at the top of the Allegheny Formation is missing over much of the area because of erosion. Three Pottsville coals that are present not far below the base of the Allegheny Formation - the Lower Mercer (No. 3), Upper Mercer (No. 3A), and the Tionesta (No. 3B) - are mined locally. Because of their localized presence, not all of the above-mentioned coals are listed in figure 4.

Coal output in 1989 included production from the No. 4 coal near Millersburg and from the No. 5 and No. 6 coals in Coshocton County between Doughty and Mill Creeks (fig. 18).
A number of sites across the basin are under permit to extract either the No. 5 or No. 6 coal. Most of these are in the southeastern part of the basin not far from Coshocton.

Unconsolidated and bedrock aquifers are important water supplies in the basin. The unconsolidated aquifers consist of thick deposits of sand and gravel that are present in much of the glaciated area and are largely restricted to outwash valleys south of the glaciated area. Well yields from these deposits can exceed $1,000 \mathrm{gal} / \mathrm{min}$; for bedrock aquifers, however, yields are generally less than $25 \mathrm{gal} / \mathrm{min}$ (Crowell, 1979; Sugar, 1988). The Cuyahoga and Logan Formations of Mississippian age are a bedrock source of water along the western parts of the basin, and many wells in this area that yield from these units are more than $400 \mathrm{ft}$ deep. The use of these bedrock sources is limited in places by depth or a change in rock composition from sandstone to shale. In Coshocton County, the Pottsville Formation is a common bedrock source of water supply. Also available are shallow local supplies in sandstone, limestone, and coal units of the Allegheny Formation.

\section{Water Quality}

In addition to two long-term streamwater sites, five short-term sites were selected for a synoptic sampling of the basin. Ground-water samples were collected from four wells in the southern third of the basin, the area of most of the surface-mining activity.

The streamwater sites in the table on the next page were sampled in June 1991 because of high flow in fall 1990. Their locations are shown in figure 18.

The Walhonding River and Killbuck Creek receive substantial flow from drainage basins upstream. Sampling sites on these streams would not be diagnostic of conditions within the basin. 


\begin{tabular}{lclc}
$\begin{array}{c}\text { Map index } \\
\text { number }\end{array}$ & Site type & \multicolumn{1}{c}{ Site name } & $\begin{array}{c}\text { Drainage area } \\
\text { (square miles) }\end{array}$ \\
\hline & & & 27.2 \\
J-1 & Long term & Mill C nr Coshocton & 16.4 \\
J-2 & do. & Simmons Rn nr Warsaw & 8.0 \\
J-3 & Short term & Bucklew Rn nr Warsaw & 13.6 \\
J-4 & do. & Beaver Rn at Warsaw & 59.7 \\
J-5 & do. & Doughty C nr Clark & 23.1 \\
J-6 & do. & Wolf C nr Killbuck & 22.9 \\
J-7 & do. & Martins C nr Holmesville & \\
\hline
\end{tabular}

Therefore, the long-term sites, J-1 and J-2, were established on principal tributaries. At site $\mathrm{J}-1$, the USGS has operated a streamflowgaging station since 1936.

Because backwater along the lower reaches of most tributaries to Killbuck Creek was common, sites J-3, J-5, and J-6 were located upstream at places where a suitable discharge measurement could be made. All short-term sites were on streams that drain areas believed to contain coal-bearing strata. Some of the sites permitted for mining are included in these areas.

Results of analyses of water samples (table 15) show that, of the seven sites sampled, the highest specific conductances were found at sites J-2 $(1,290 \mu \mathrm{S} / \mathrm{cm})$ and J-3 $(825 \mu \mathrm{S} / \mathrm{cm})$. Dissolved-sulfate concentrations were also at or near the maximum in water from these two sites; water from site J-2 had the highest dissolved-sulfate concentration $(700 \mathrm{mg} / \mathrm{L})$ (table 16). High concentrations of aluminum, iron, and manganese, often associated with acid mine drainage, were not found in any waters sampled in the basin. Values for $\mathrm{pH}$ were in the alkaline range at all sites; the median was 7.8 (fig. 19).

\section{Ground water}

Water from four wells opening into the shallow, unconsolidated aquifer underlying the Walhonding Valley was sampled. The town of Warsaw and the city of Coshocton draw their supply from the same aquifer.

Water-quality data for four ground-water sites sampled in August 1990 are shown in table 17. Values of $\mathrm{pH}$ ranged from 7.2 to 7.7 , and concentrations of constituents commonly associated with acid mine drainage were not high. The Stiff diagrams (fig. 18) show that all four wells contain calcium bicarbonate-type waters.

The water from wells Cs-153, Cs-154, and Cs-155 met all OEPA water-quality standards for public supplies for the constituents reported. The concentration of dissolved solids in water from well Cs-156 only slightly exceeded the water-quality standard $(500 \mathrm{mg} / \mathrm{L})$. The waters are classified as hard to very hard. 
Table 15. Water-quality data for streamwater sites in Walhonding River basin, June 1991

$\left[{ }^{\circ} \mathrm{C}\right.$, degrees Celsius; $\mathrm{ft}^{3} / \mathrm{s}$, cubic feet per second; mg/L, milligrams per liter; $\mu \mathrm{g} / \mathrm{L}$, micrograms per liter; $\mu \mathrm{S} / \mathrm{cm}$, microsiemens per centimeter at 25 degrees Celsius; --, data not available]

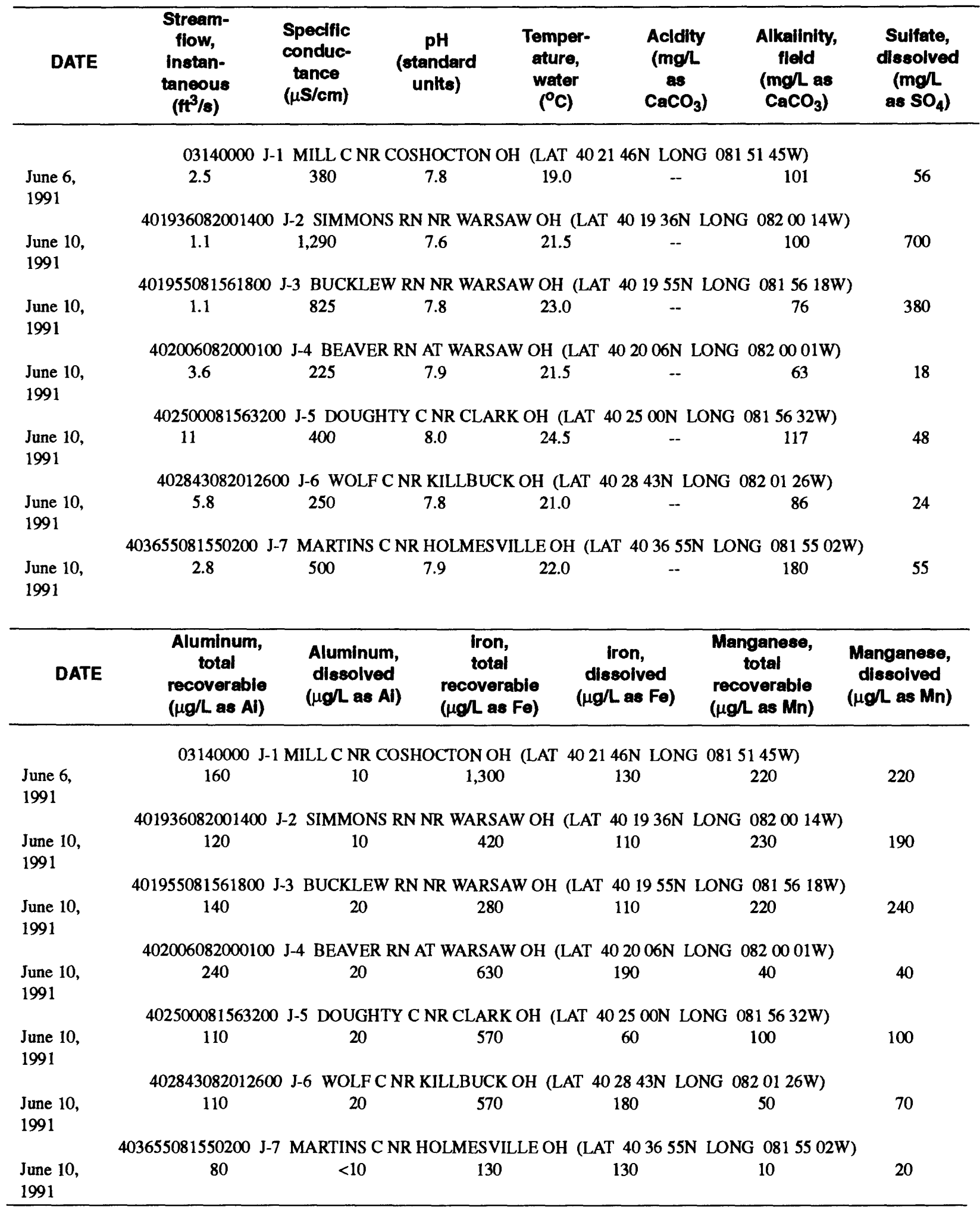


Table 16. Ranges and medians for selected water-quality characteristics for streamwater sites in Walhonding River basin, June 1991

[mg/L, milligrams per liter; $\mu \mathrm{g} / \mathrm{L}$, micrograms per liter; $\mu \mathrm{S} / \mathrm{cm}$, microsiemens per centimeter at 25 degrees Celsius]

\begin{tabular}{|c|c|c|c|}
\hline $\begin{array}{l}\text { Property or } \\
\text { constituent }\end{array}$ & Range & $\begin{array}{l}\text { Locations }^{a} \\
\text { (fig. 18) }\end{array}$ & Median \\
\hline $\begin{array}{l}\text { Specific conductance, } \\
\text { in } \mu \mathrm{S} / \mathrm{cm}-\end{array}$ & $\begin{array}{l}225 \text { to } 1,290 \\
7.6 \text { to } 8.0\end{array}$ & $\begin{array}{l}\mathrm{J}-4 ; \mathrm{J}-2 \\
\mathrm{~J}-2 ; \mathrm{J}-2\end{array}$ & $\begin{array}{r}400 \\
7.8\end{array}$ \\
\hline $\begin{array}{l}\text { Alkalinity, in } \mathrm{mg} / \mathrm{L} \\
\text { as } \mathrm{CaCO}_{3}\end{array}$ & 63 to 180 & $\mathrm{~J}-4 ; \mathrm{J}-7$ & 100 \\
\hline $\begin{array}{l}\text { Sulfate, dissolved, } \\
\text { in } \mathrm{mg} / \mathrm{L} \text { as } \mathrm{SO}_{4}---- \\
\text { Aluminum, total, }\end{array}$ & 18 to 700 & $\mathrm{~J}-4 ; \mathrm{J}-2$ & 55 \\
\hline $\begin{array}{l}\text { in } \mu \mathrm{g} / \mathrm{L} \text { as } \mathrm{Al}- \\
\text { Aluminum, dissolved, }\end{array}$ & 80 to 240 & $\mathrm{~J}-7 ; \mathrm{J}-4$ & 120 \\
\hline $\begin{array}{l}\text { in } \mu \mathrm{g} / \mathrm{L} \text { as } \mathrm{A} 1 \text { - } \\
\text { Iron, total, }\end{array}$ & $<10$ to 20 & J-7; several sites & 20 \\
\hline $\begin{array}{l}\text { in } \mu \mathrm{g} / \mathrm{L} \text { as } \mathrm{Fe} \\
\text { Iron, dissolved, }\end{array}$ & 130 to 1,300 & $\mathrm{~J}-2 ; \mathrm{J}-1$ & 570 \\
\hline $\begin{array}{l}\text { in } \mu \mathrm{g} / \mathrm{L} \text { as } \mathrm{Fe}- \\
\text { Manganese, total, }\end{array}$ & 60 to 190 & $\mathrm{~J}-5 ; \mathrm{J}-4$ & 130 \\
\hline $\begin{array}{l}\text { in } \mu \mathrm{g} / \mathrm{L} \text { as } \mathrm{Mn}- \\
\text { Manganese, dissolved, }\end{array}$ & 10 to 230 & $\mathrm{~J}-7 ; \mathrm{J}-2$ & 100 \\
\hline
\end{tabular}

a Sites at which the minimum values in the ranges were measured are to the left of the semicolon. Sites at which the maximum values in the ranges were measured are to the right of the semicolon. 


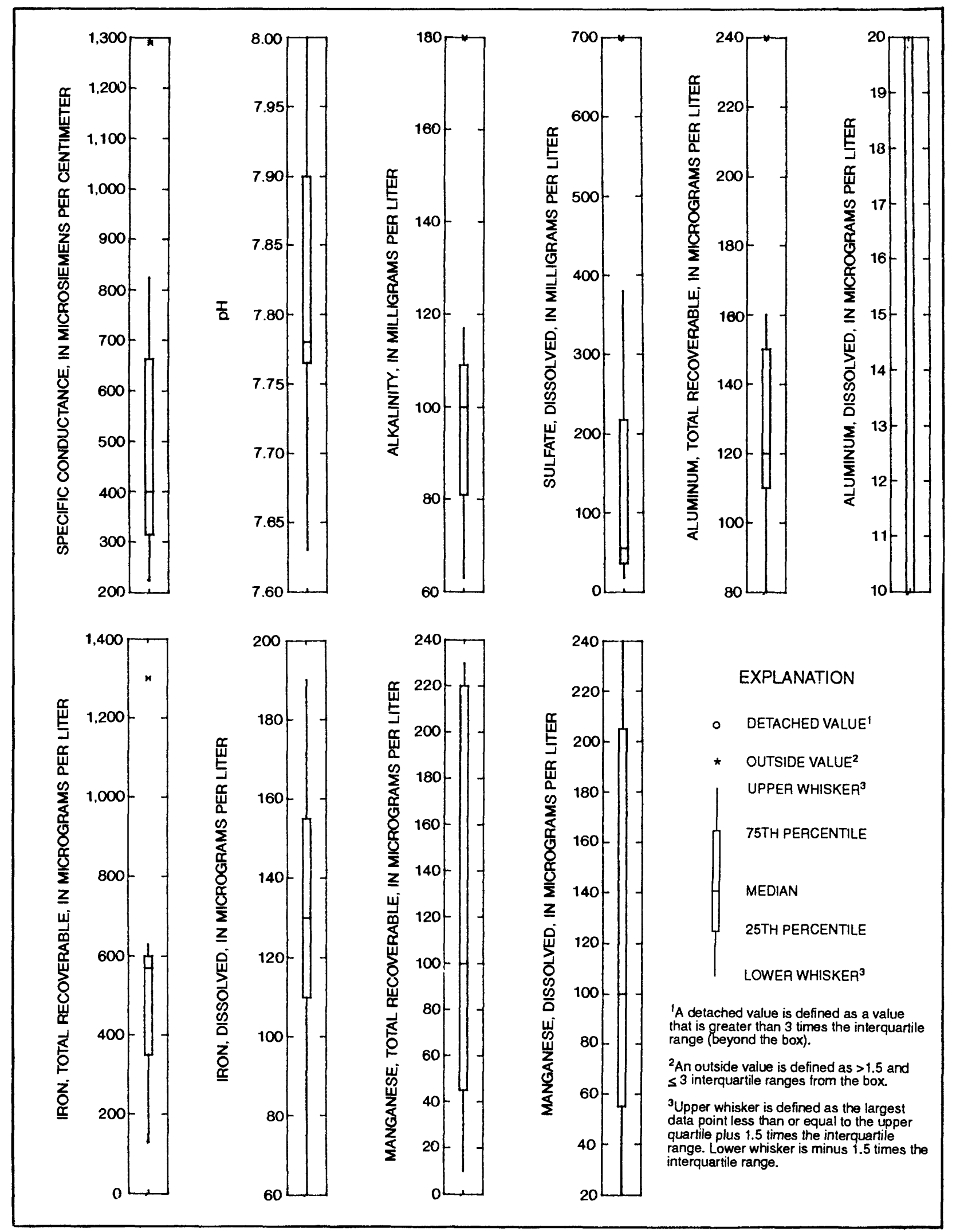

Figure 19.--Ranges, percentiles, and medians of constituents at seven streamwater sites in the Walhonding River basin. 


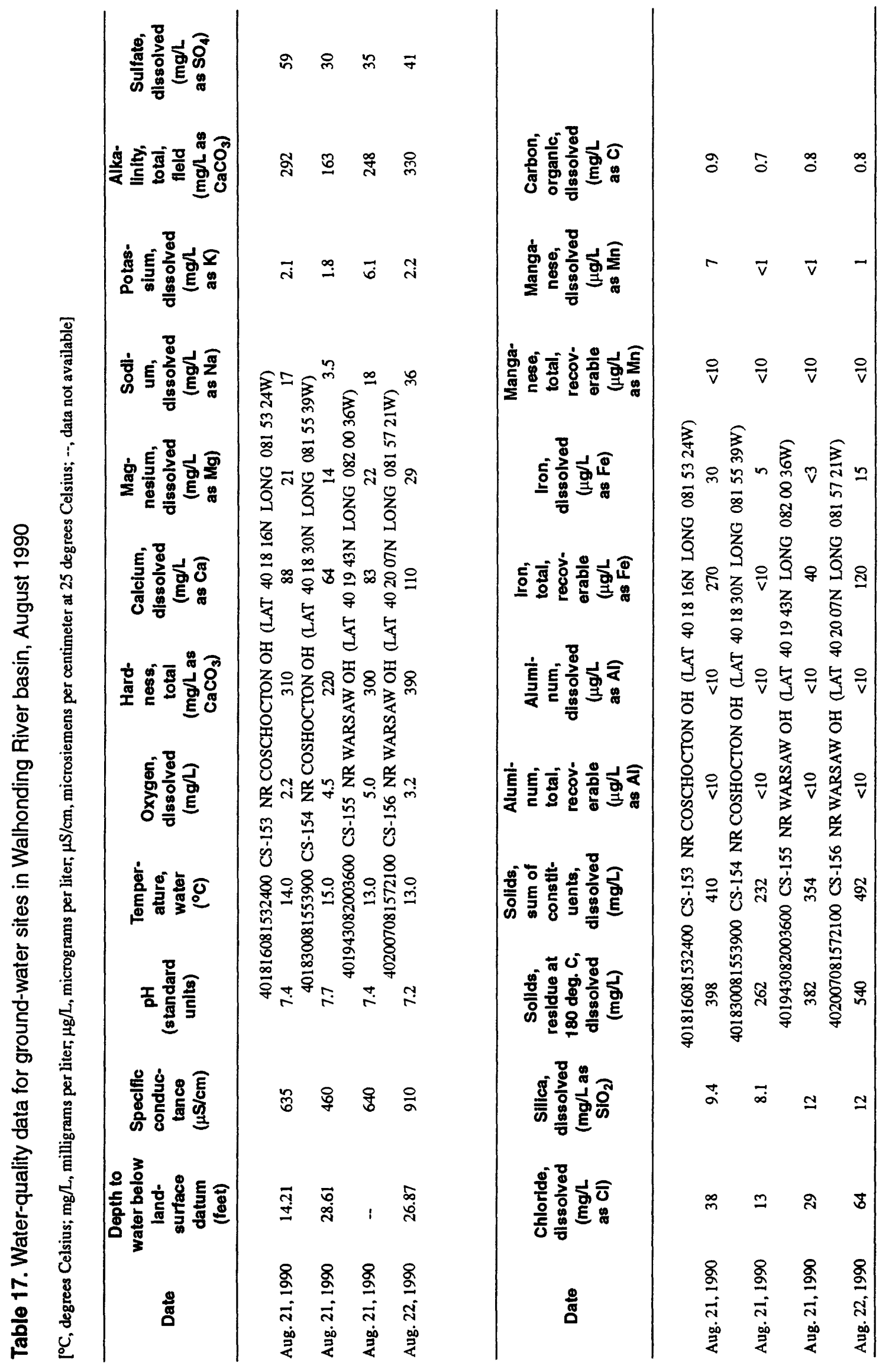




\section{Upper Muskingum River Basin}

The Upper Muskingum River basin is an irregularly shaped drainage area of $366 \mathrm{mi}^{2}$ (fig. 1, basin M). It includes what is approximately the southwestern third of Coshocton County, small parts of Knox and Licking Counties, and an irregularly shaped part of the northwestern corner of Muskingum County (fig. 20).

The Upper Muskingum River basin, as designated in this study, is the same area referred to as "part of Upper Portion of the Muskingum River basin" in the ODNR Ohio Water Plan Inventory series (Schmidt, 1962b). It includes the section of the Muskingum River that begins at the confluence of the Tuscarawas and Walhonding Rivers at Coshocton and extends to, but does not include, the confluence of the Licking River at Zanesville. Two major sources of outside flow to the basin are the TuscarawasWalhonding systems on the north and the Wills Creek system, which enters the Muskingum River near where it enters Muskingum County (fig. 20).

The largest interior drainage network is the Wakatomika Creek system, which enters the Muskingum River near Dresden (fig. 20). It drains all but a small part of the northwestern two-thirds of the basin. Except for Symmes Creek, east of Dresden (fig. 20), most of the Muskingum tributaries are less than $3 \mathrm{mi}$ in length.

About $50 \mathrm{mi}^{2}$ of the northwestern extremity of the basin was covered by older (Illinoian) glaciation. Postglacial erosion has left the landscape similar in appearance to the nonglaciated section. The glacial boundary is the basis of dividing the subject basins between the Glaciated and Unglaciated Allegheny Plateau Sections of the Appalachian Plateaus Physiographic Province.
The topographic character for most of the basin is basically that of a thoroughly dissected upland through which the main stream of the Muskingum drainage system has cut a fairly wide path between Coshocton and Dresden. Southward, toward Zanesville, the Muskingum Valley narrows considerably. A wide valley that was formed by glacial or preglacial drainage systems is now largely filled with unconsolidated material through which Wakatomika Creek follows a meandering course for about 15 mi upstream from its confluence with the Muskingum River. In contrast, the smaller tributaries draining upland areas are relatively short with steep-sided valleys. Local relief in the wide bottom valleys is negligible but, along the upland edges, can be as great as $300 \mathrm{ft}$.

\section{Geologic Setting}

Major bedrock underlying the basin, in ascending order of age, consists of sandstones and shales of Mississippian age and coalbearing strata of Pennsylvanian age. The oldest unit is the Cuyahoga Formation, a prominent member of which is the Black Hand Sandstone. Outcrops of the Black Hand Sandstone are visible in western parts of the basin.

Toward the east, the Cuyahoga Formation and the overlying Logan Formation form the valley bottoms of northwestern Muskingum County. The overlying Pottsville Formation forms much of the upland area north and south of Wakatomika Creek and much of the southwestern corner of Coshocton County. Overlying the Pottsville and capping many of the hills in the western part of the basin are remnants of the Allegheny Formation that contain mineable coals. Near the Muskingum River in Coshocton County and east of the river in Muskingum County, the Conemaugh Formation is present as scattered remnants that thicken to the east. 


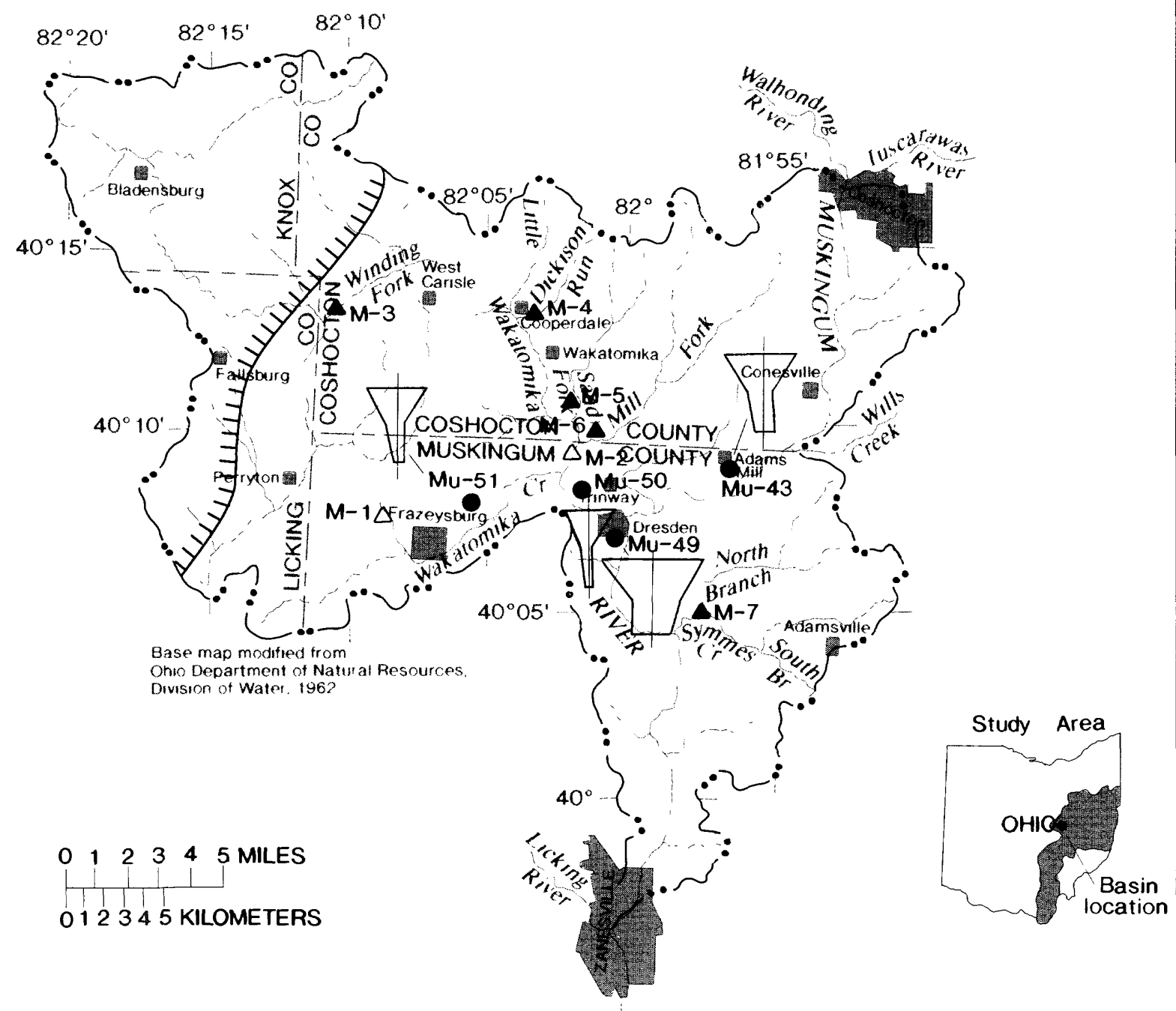

\section{EXPLANATION}

- - BASIN BOUNDARY

Цل」 GLACIAL BOUNDARY--From Golthwait, and others, 1961

$\triangle$ M-7 SHORT-TERM SURFACE-WATER SITE AND NUMBER

$\triangle M-1$ LONG-TERM SURFACE-WATER SITE AND NUMBER

Mu-51 WELL AND NUMBER
DIAGRAM SHOWING CONCENTRATIONS OF CATIONS AND ANIONS

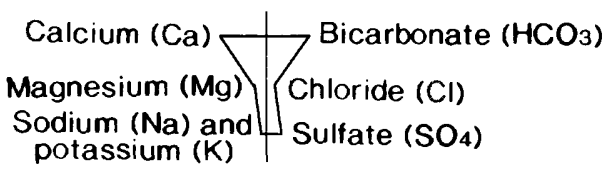

Cations $\mid \begin{array}{ccccccc} & \mid & \mid & \mid & \mid & \mid & \mid \\ 15 & 10 & 5 & 0 & 5 & 10 & 15\end{array}$ Anions Milliequivalents per liter

Figure 20.--Upper Muskingum River basin (M), streamwater sites, ground-water sites, and Stiff diagrams for ground-water sites. 
Recent coal production (Lopez, 1991) is mostly confined to the Middle Kittanning (No. 6) coal east of the Muskingum River northeast of Zanesville, including one underground mine. Many areas have been mined out, but numerous areas up and down the eastern part of the basin are under permit to mine the No. 6 coal. The permit list includes as objectives the Lower Kittanning (No. 5) and Upper Freeport (No. 7) coals.

Unconsolidated aquifers are the source of an important water supply in the basin. In places, the valley fill is more than $100 \mathrm{ft}$ thick along the Muskingum River between Coshocton and Dresden (fig. 20). Unconsolidated valley fill can yield as much as $1,000 \mathrm{gal} / \mathrm{min}$ in this area, where the Muskingum River is a source of induced recharge (Schmidt, 1962b). Westward along Wakatomika Creek and into Licking County, unconsolidated materials underlie the main valley. Yields to wells in this area are sufficient for small public supplies.

Bedrock aquifers also are important as a water supply in the basin. Maps by Schmidt (1962b, 1980), Hartzell (1982), and Sugar (1988) show possible yields of 10 to $25 \mathrm{gal} / \mathrm{min}$ for bedrock areas of the basin that are underlain by sandstones of the Cuyahoga, Logan, and Pottsville Formations. In contrast, through the center of the basin, yields to wells are meager (yields generally less than $3 \mathrm{gal} / \mathrm{min}$ ). In this upland area, the upper part of the Allegheny Formation and the lower part of the Conemaugh Formation form the surficial terrain. The sandstones that yield more water are more deeply buried.

\section{Water Quality}

Two long-term streamwater sites and five short-term sites were selected for a synoptic sampling of the basin. In addition, ground- water samples were collected from four wells in the northern part of Muskingum County.

Because of high flow in 1990, the streamwater sites in the table on the next page were sampled in early June 1991. Their locations are shown in figure 20.

Two long-term streamwater sites (fig. 20, M-1 and M-2) were placed along the Wakatomika drainage system, an area that was formerly mined. Short-term sites were selected to maximize synoptic coverage of the basin.

Water-quality data for streamwater sites show that specific conductance was greater than $1,000 \mu \mathrm{S} / \mathrm{cm}$ in samples from sites $\mathrm{M}-2$, $M-5$, and M-6 (table 18). The median specific conductance for all sites within the basin was $965 \mu \mathrm{S} / \mathrm{cm}$ (table 19). Dissolved-sulfate concentrations were especially high at site M-6 but were also high at sites M-2, M-5, and M-7. Concentrations of total recoverable and dissolved manganese were greater than $1,000 \mu \mathrm{g} / \mathrm{L}$ at sites $\mathrm{M}-2$ and M-6. Values for $\mathrm{pH}$ were in the slightly alkaline range; the median was 8.0. In figure 21 , outside values are shown for total recoverable and dissolved manganese (site M-6), total recoverable aluminum (site M-6), and dissolved iron (site M-3) (fig. 21). Because dissolved-aluminum concentrations were below detection limits at four out of seven sites, box plots for this constituent were not constructed.

Water from site $\mathbf{M}-6$, and, to a lesser extent, from sites M-2, M-5, and M-7, had high specific conductance and high concentrations of some of the constituents commonly associated with acid mine drainage. For all sites in the basin, however, $\mathrm{pH}$ in the alkaline range indicates that streamwaters may have been buffered by runoff or diluted by alkaline waters. 


\begin{tabular}{|c|c|c|c|}
\hline $\begin{array}{l}\text { Map index } \\
\text { number }\end{array}$ & Site type & Site name & $\begin{array}{l}\text { Drainage area } \\
\text { (square miles) }\end{array}$ \\
\hline M-1 & Long term & Wakatomika C nr Frazeysburg & 140.0 \\
\hline M-2 & do. & L. Wakatomika C nr Trinway & 61.1 \\
\hline M-3 & Short term & $\begin{array}{l}\text { Winding F Wakatomika C } \\
\mathrm{nr} \mathrm{W.} \mathrm{Carlisle}\end{array}$ & 21.0 \\
\hline M-4 & do. & Dickinson $\mathrm{Rn}$ at Cooperdale & 4.1 \\
\hline M-5 & do. & Sand F nr Wakatomika & 8.7 \\
\hline M-6 & do. & Mill F nr Trinway & 24.5 \\
\hline M-7 & do. & Symmes C nr Dresden & 31.3 \\
\hline
\end{tabular}

\section{Ground water}

Ground-water quality was determined by sampling four wells yielding from shallow, unconsolidated sediments that are major industrial and domestic water-supply aquifers in the area. Three of the wells (Mu-43, Mu-49, and $\mathrm{Mu}-50$ ) were close to the Muskingum River. Well Mu-51, near the town of Frazeysburg, yields from a buried-valley system not traversed by a large stream at the surface.

Water-quality data for four ground-water sites sampled in August 1990 are given in table 20. Values for $\mathrm{pH}$ ranged from 7.4 to 7.9 , and concentrations of constituents associated with acid mine drainage were not high.

As shown on the Stiff diagram (fig. 20), well $\mathrm{Mu}-50$ contains calcium bicarbonate-type waters. The ions that dominate the waters from wells Mu-43 and Mu-51 are calcium, bicarbonate, and, to a lesser extent, sulfate (fig. 20). The highly mineralized character of water from well Mu-49 is shown in the Stiff diagram of this well. The ground waters are classified as moderately hard (Mu-50), hard (Mu-51 and Mu-43), and very hard (Mu-49).
The OEPA water-quality standard for dissolved manganese $(50 \mu \mathrm{g} / \mathrm{L})$ was exceeded in water from wells $\mathrm{Mu}-49, \mathrm{Mu}-50$, and $\mathrm{Mu}-51$ (table 20). The water-quality standard for iron $(300 \mu \mathrm{g} / \mathrm{L})$ was exceeded in water from wells $\mathrm{Mu}-50$ and Mu-51. Water from well Mu-49, a public-supply well, also exceeded the waterquality standard for dissolved solids (500 mg/L).

\section{Middle Muskingum River Basin}

The Middle Muskingum River Basin, which drains an area of $470 \mathrm{mi}^{2}$, covers approximately the south-central third of Muskingum County, the northeastern third of Morgan County, and a small part of the northwestern corner of Noble County (fig. 1, basin $\mathrm{N})$. The basin corresponds to the same area referred to as "a portion of the Middle uskingum River Basin" (Walker, 1962a) in the ODNR Water Plan Inventory series maps. 
Table 18. Water-quality data for streamwater sites in Upper Muskingum River basin, June 1991

$\left[{ }^{\circ} \mathrm{C}\right.$, degrees Celsius; $\mathrm{ft}^{3} / \mathrm{s}$, cubic feet per second; mg/L, milligrams per liter; $\mu \mathrm{g} / \mathrm{L}$, micrograms per liter; $\mu \mathrm{S} / \mathrm{cm}$, microsiemens per centimeter at 25 degrees Celsius; --, data not available]

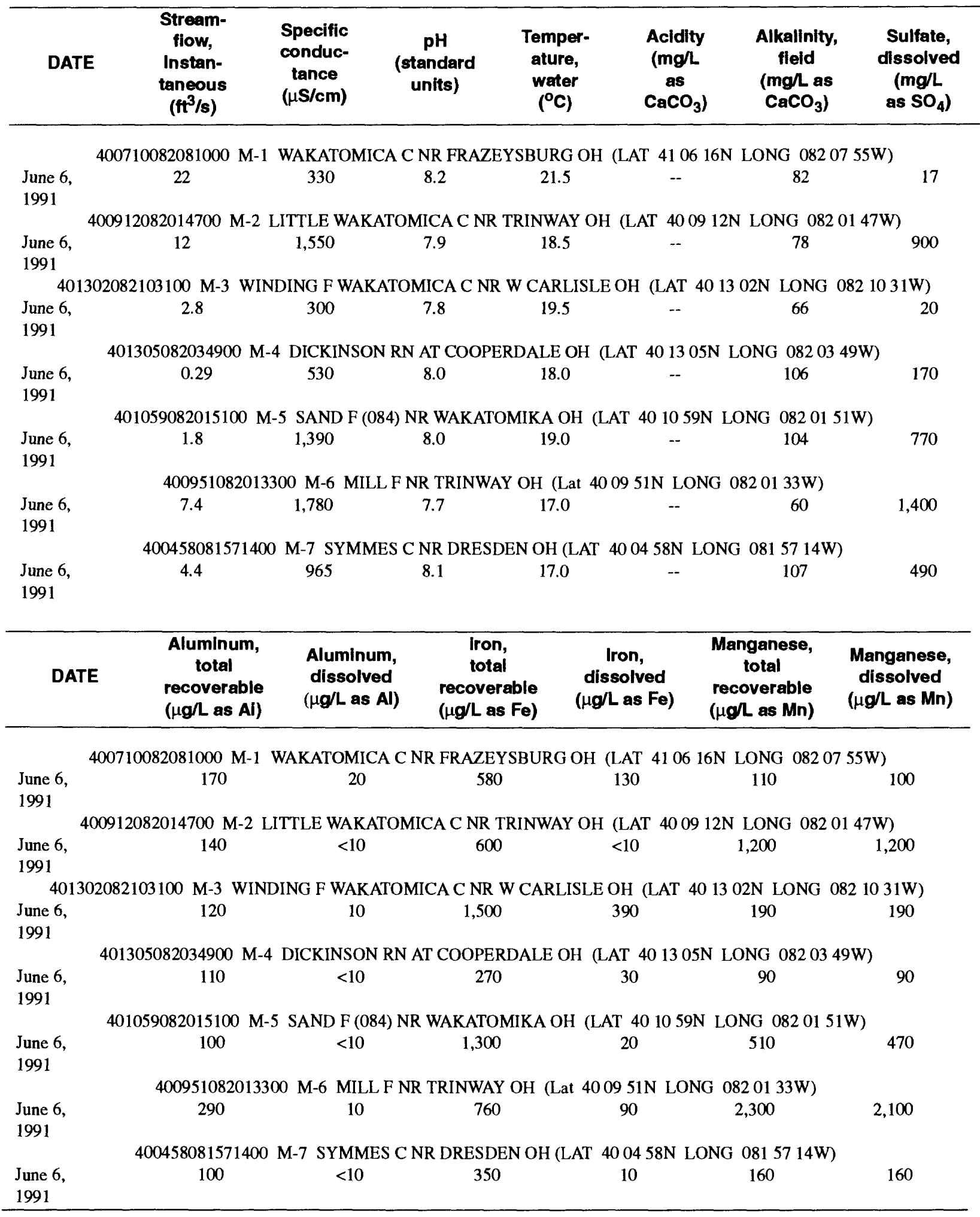


Table 19. Ranges and medians for selected water-quality characteristics for streamwater sites in Upper Muskingum River basin, June 1991

[mg/L, milligrams per liter; $\mu \mathrm{g} / \mathrm{L}$, micrograms per liter; $\mu \mathrm{S} / \mathrm{cm}$, microsiemens per centimeter at 25 degrees Celsius]

\begin{tabular}{|c|c|c|c|}
\hline $\begin{array}{l}\text { Property or } \\
\text { constituent }\end{array}$ & Range & $\begin{array}{l}\text { Locations }^{a} \\
\text { (fig. 20) }\end{array}$ & Median \\
\hline $\begin{array}{l}\text { Specific conductance, } \\
\text { in } \mu \mathrm{S} / \mathrm{cm}- \\
\text { pH-- }\end{array}$ & $\begin{array}{l}300 \text { to } 1,780 \\
7.7 \text { to } 8.2\end{array}$ & $\begin{array}{l}\text { M-3; M-6 } \\
\text { M-6; M-1 }\end{array}$ & $\begin{array}{r}965 \\
8.0\end{array}$ \\
\hline $\begin{array}{l}\text { Alkalinity, in } \mathrm{mg} / \mathrm{L} \\
\text { as } \mathrm{CaCO}_{3}\end{array}$ & 60 to 107 & M-6; M-7 & 82 \\
\hline $\begin{array}{l}\text { Sulfate, dissolved, } \\
\text { in } \mathrm{mg} / \mathrm{L} \text { as } \mathrm{SO}_{4}-{ }^{---} \\
\text {Aluminum, total, }\end{array}$ & 17 to 1,400 & M-1; M-6 & 490 \\
\hline $\begin{array}{l}\text { in } \mu \mathrm{g} / \mathrm{L} \text { as } \mathrm{Al}-- \\
\text { Aluminum, dissolved, }\end{array}$ & 100 to 290 & M-5, 7; M-6 & 120 \\
\hline $\begin{array}{l}\text { in } \mu \mathrm{g} / \mathrm{L} \text { as } \mathrm{A} 1 \text { - } \\
\text { Iron, total, }\end{array}$ & $<10$ to 20 & Several sites; M-1 & $<10$ \\
\hline $\begin{array}{l}\text { in } \mu \mathrm{g} / \mathrm{L} \text { as } \mathrm{Fe} \\
\text { Iron, dissolved, }\end{array}$ & 270 to 1,500 & M-4; M-3 & 600 \\
\hline $\begin{array}{l}\text { in } \mu \mathrm{g} / \mathrm{L} \text { as } \mathrm{Fe}- \\
\text { Manganese, total, }\end{array}$ & $<10$ to 390 & M-2; M-3 & 30 \\
\hline $\begin{array}{l}\text { in } \mu \mathrm{g} / \mathrm{L} \text { as } \mathrm{Mn}- \\
\text { Manganese, dissolved, } \\
\text { in } \mu \mathrm{g} / \mathrm{L} \text { as } \mathrm{Mn}\end{array}$ & 90 to 2,300 & M-4; M-6 & 190 \\
\hline
\end{tabular}

a Sites at which the minimum values in the ranges were measured are to the left of the semicolon. Sites at which the maximum values in the ranges were measured are to the right of the semicolon. 

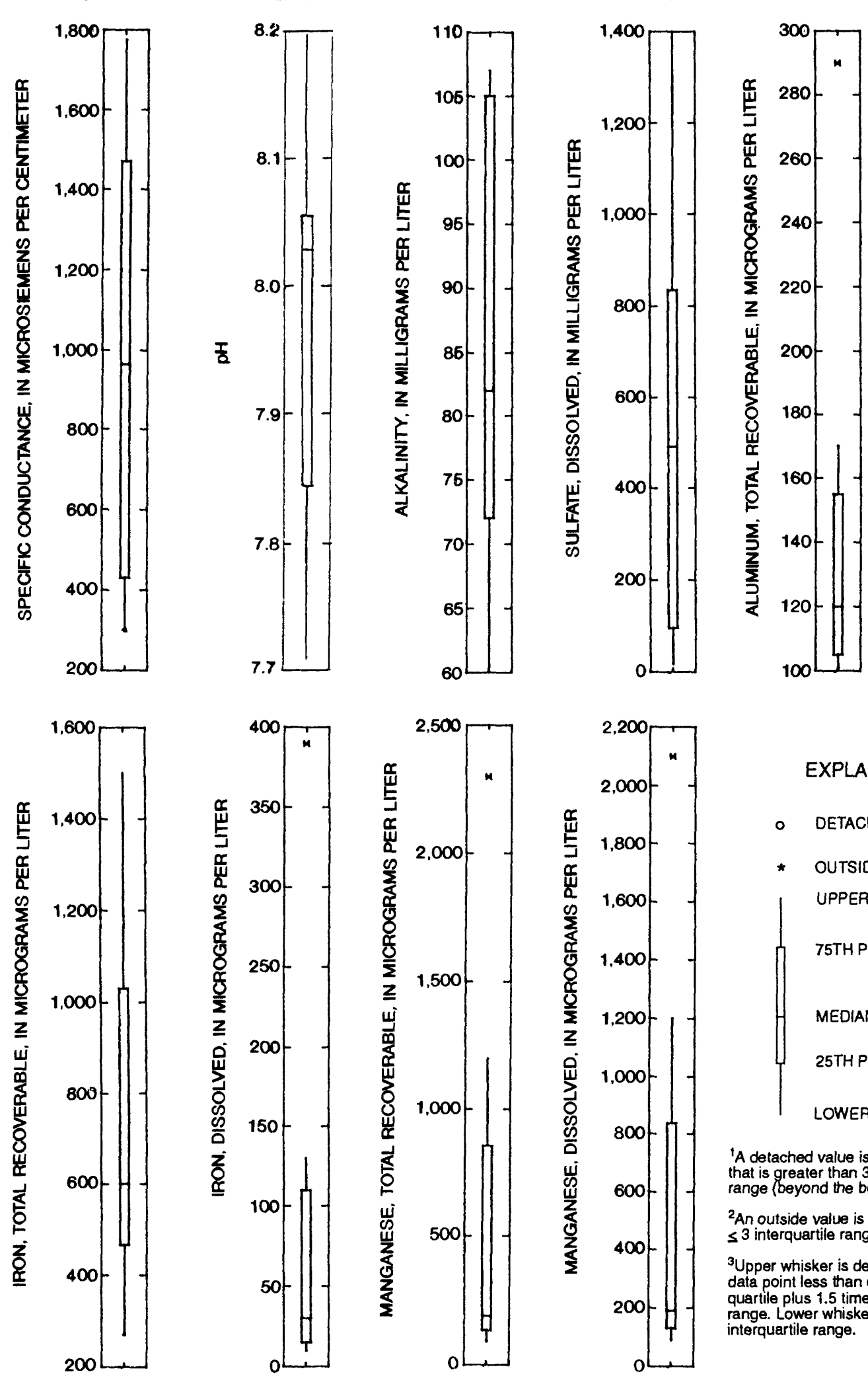

\section{EXPLANATION}

- Detached Value 1

* outside value ${ }^{2}$

UPPER WHISKER ${ }^{3}$

75TH PERCENTILE

MEDIAN

25TH PERCENTILE

LOWER WHISKER ${ }^{3}$

IA detached value is defined as a value that is greater than 3 times the interquartile range (beyond the box).

${ }^{2}$ An outside value is defined as $>1.5$ and $\leq 3$ interquartile ranges from the box.

3 Upper whisker is defined as the largest data point less than or equal to the upper quartile plus 1.5 times the interquartile quartile plus 1.5 times the interquartile
range. Lower whisker is minus $\{.5$ times the interquartile range.

Figure 21.--Ranges, percentiles, and medians of constituents at seven streamwater sites in the Upper Muskingum River basin. 


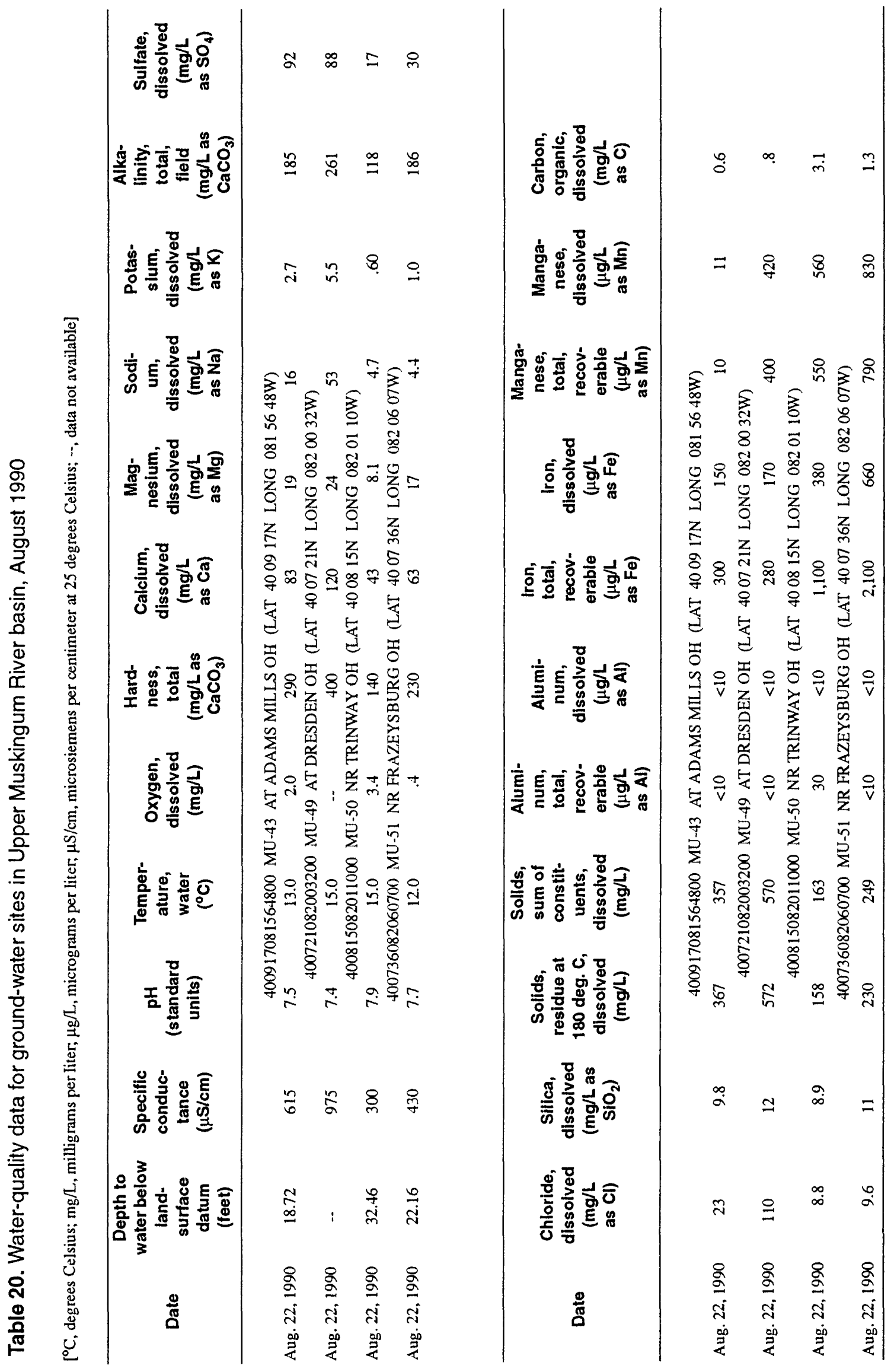


The drainage network of the upper end of the Middle Muskingum River basin is somewhat complex. On the eastern bank of the Muskingum River, just northeast of Zanesville (fig. 22), discharge that enters from Mill Run is the most upstream source of drainage from within the Middle Muskingum River basin itself. Upstream from Zanesville, the Muskingum River, which enters from the Upper Muskingum River basin, drains much of the coal-bearing region of Ohio. At the confluence of the Licking River in the center of Zanesville, drainage from the Licking River basin (not part of the study area) enters the Muskingum River. Included in the Middle Muskingum River basin is a small area $\left(3.8 \mathrm{mi}^{2}\right)$ drained by Chaps Run. Chaps Run drains into the western bank of the Muskingum River and is between the Licking River basin and the Moxahala Creek basin (fig. 1, basin $\mathrm{O})$, which was discussed in an earlier report (Jones, 1988). Thus, the Middle Muskingum River basin receives drainage from three major sources.

Meigs Creek, which enters the Muskingum River at the downstream end of the basin, drains about half of the subject basin. Salt Creek, which enters the Muskingum River at Duncan Falls (fig. 22), drains much of the northern third of the Middle Muskingum River basin. The prevailing direction of streamflow is southward to eastward. The biggest exception is Brush Creek, which flows to the north along the western edge of the basin before entering the Muskingum River midway between Zanesville and Philo (fig. 22).

The Muskingum River valley narrows considerably along its southward approach toward Zanesville. Southward from Duncan Falls and Philo, the Muskingum River flows in a slightly meandering valley that is only a few times the width of the river channel. The valley floor stands in sharp contrast to the adjacent highlands. The same area forms a narrow subbasin along the southwestern side of the Middle Muskingum River basin, within which numerous short streams that have cut steepsided valleys in the upland empty directly to the Muskingum River. Downstream from Stockport, the valley widens somewhat. Elsewhere in the basin, the drainage systems assume more of a spread-out, dendritic pattern, and the topography is less rugged.

The nearest glacial limit is about $10 \mathrm{mi}$ to the west in Perry County (fig. 1, basin O). Thus, the Middle Muskingum River basin is in the Unglaciated Allegheny Plateau Section of the Appalachian Plateaus Physiographic Province.

\section{Geologic Setting}

The stratigraphic succession, in ascending order and generally from northwest to southeast across the study basin, consists primarily of the Pottsville, Allegheny, Conemaugh, and Monongahela Formations of Pennsylvanian age. Upper units of the Pottsville are present in valley bottoms near Zanesville. In the same area are scattered remnants of coal-bearing units of the Allegheny Formation. The coalbearing units are more extensive east of the Muskingum River and along Brush Creek to the south. The Middle Kittanning and Upper Freeport coals (No. 6 and No. 7) have been mined in the area. Allegheny outcrops are present along the Muskingum Valley below Philo for several miles.

The Conemaugh Formation, with its thick assemblage of shales, shaly sandstones, thin limestones, and minor coals, is present in much of the northern part of the basin and along the western part of the basin south of Zanesville. Farther east and south, the Conemaugh Formation is more extensive. Toward the southeastern corner of Muskingum County and into Morgan County, it is overlain by widespread remnants of the Monongahela Formation. 


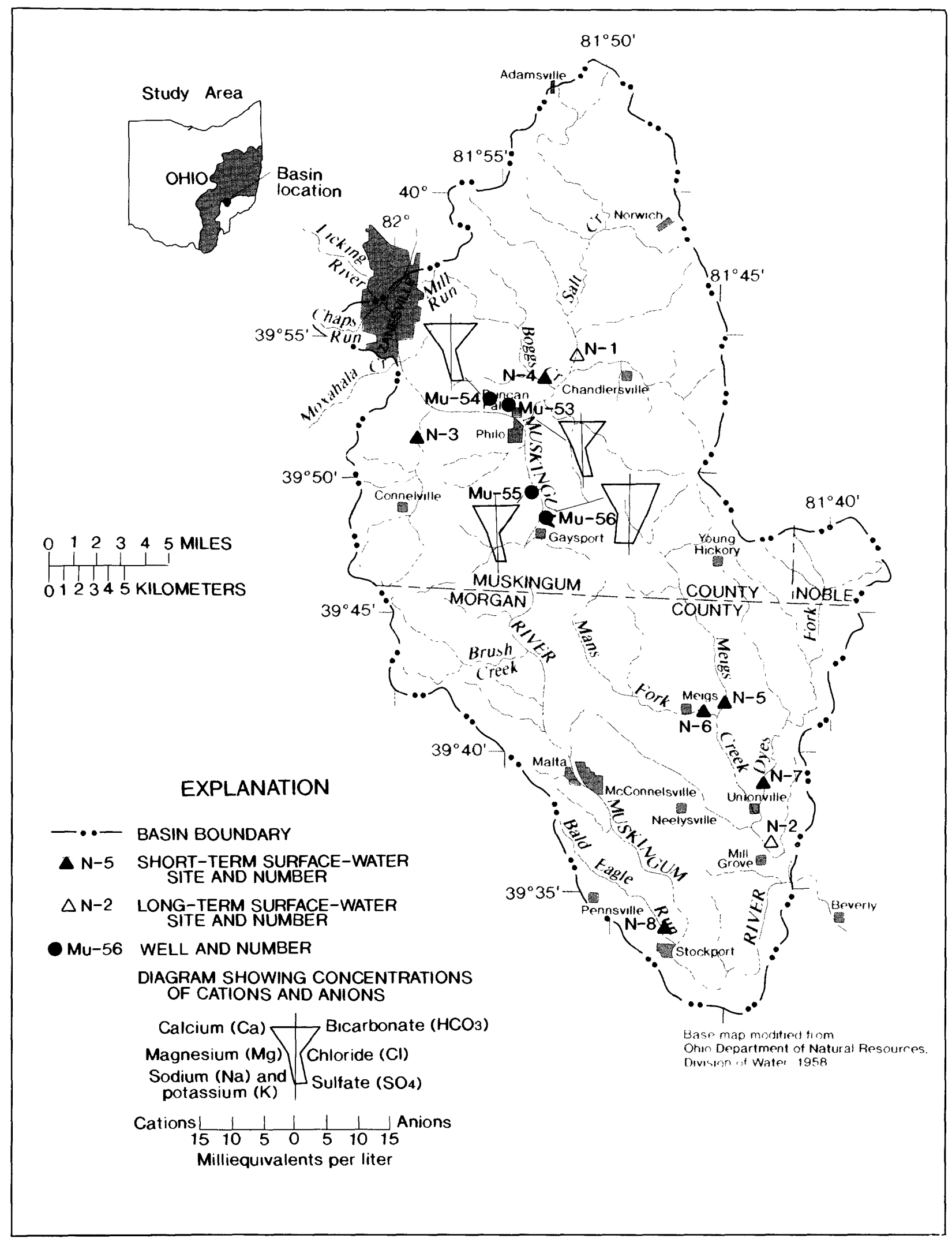

Figure 22.--Middle Muskingum River basin (N), streamwater sites, ground-water sites, and Stiff diagrams for ground-water sites. 
In the basin, the Pittsburgh (No. 8) coal and the Meigs Creek (No. 9) coal in the Monongahela Formation have been heavily surface mined. In places, the Uniontown (No. 10) and the Waynesburg (No. 11) coals are present.

The rock succession exhibits the usual regional east-to-southeast dip toward the Appalachian Basin. A minor structural flexure, the Parkersburg-Lorain Syncline, causes the rocks to increase in dip along the eastern side of the basin such that basal remnants of Permian rocks cap the Pennsylvanian strata. The Parkersburg-Lorain Syncline is a minor structure that is roughly parallel to the Cambridge Arch (Lamborn, 1951), discussed earlier for the Lower Wills Creek basin.

Most of the more valuable coal (No. 9) has been mined out. Recent data (Lopez, 1991) indicate no production for Morgan County in 1989 and minor production of Middle Kittanning (No. 6) coal near Zanesville in Muskingum County. Along the Muskingum-Noble county line, production of the Meigs Creek (No. 9) coal amounted to about 8 percent of Ohio's production for 1989.

Alluvial fill in places along the Muskingum River yields 100 to $500 \mathrm{gal} / \mathrm{min}$ and is an important source of supply for several communities in the valley. In contrast, the rock succession for most of the basin yields poorly to wells. Yields of 5 to $25 \mathrm{gal} / \mathrm{min}$ are possible in a small area around and south of Zanesville (Walker, 1962a). In this area, Pottsville and lower Allegheny strata are present and are recharged by precipitation and streams. The same units traced southeastward are deeply buried under younger strata, and brines are likely to be present about $250 \mathrm{ft}$ below valley floors (Stout and others, 1943). Water-resource maps from ODNR (Walker, 1962a, 1984) indicate that bedrock yields of 3 to $5 \mathrm{gal} / \mathrm{min}$ or less can be expected for most of the basin.

\section{Water Quality}

Two long-term streamwater sites and six short-term sites scattered throughout the basin were used to assess streamwater quality in the Middle Muskingum River basin. Four groundwater sites in Muskingum County, between Duncan and Gaysport, were chosen to assess ground-water quality.

The streamwater sites listed in the table on the next page were sampled in late October 1991. Their locations are shown in figure 22.

The Muskingum River carries runoff for a large part of eastern Ohio, and data-collection sites on the main stream would not be representative of sampling and conditions in the basin. Therefore, long-term surface-water sites were established on the two largest tributary systems, Salt Creek and Meigs Creek (fig. 22, N-1 and N-2, respectively). Sites N-4 and $\mathrm{N}-7$ drain areas of active mining, sites $\mathrm{N}-3, \mathrm{~N}-5$, and $\mathrm{N}-6$ drain areas of former mining, and site $\mathrm{N}-8$ drains an area of little or no mining. Analyses of water samples show that water quality at site $\mathrm{N}-3$ was different from that of the seven other streamwater sites in the basin (table 21). Unlike the other sites, where $\mathrm{pH}$ values were in the alkaline range, water at site $\mathrm{N}-3$ was strongly acidic and had high concentrations of aluminum, iron, and manganese. At site N-3, concentrations of total recoverable and dissolved iron, aluminum, and manganese were at the top of the range of values (table 22). Site N-3 and three other sites (N-2, N-5, and N-6) had sulfate concentrations greater than $1,000 \mathrm{mg} / \mathrm{L}$. The medians for specific conductance and dissolved-sulfate concentrations were higher than the medians for most of the other basins examined in this report. Except for site N-3, all of the values of constituents at surface-water sites were within the interquartile ranges and whiskers of box plots in figure 23; for site $\mathrm{N}-3$, detached values are shown for $\mathrm{pH}$ and concentrations of aluminum, iron, and manganese. 


\begin{tabular}{lclr}
\hline $\begin{array}{c}\text { Map index } \\
\text { number }\end{array}$ & Site type & \multicolumn{1}{c}{ Site name } & $\begin{array}{c}\text { Drainage area } \\
\text { (square miles) }\end{array}$ \\
\hline & & & \\
N-1 & Long term & Salt C nr Chandlersville & 75.7 \\
N-2 & do. & Meigs C nr Beverly & 136.0 \\
N-3 & Short term & Brush C nr Philo & 20.5 \\
N-4 & do. & Boggs C nr Duncan Falls & 17.9 \\
N-5 & do. & Meigs C nr Meigs & 35.7 \\
N-6 & do. & Mans F nr Meigs & 28.0 \\
N-7 & do. & Dyes F nr Unionville & 87.9 \\
N-8 & do. & Bald Eagle Rn nr Stockport & 9.5 \\
\hline
\end{tabular}

Water-quality analyses show the effects of acid mine drainage on surface-water quality in the basin. The effects are especially pronounced at site $\mathrm{N}-3$ where acidic conditions exist. This site is in the western part of the basin (fig. 22), where mining of Allegheny coals took place in the past. Water samples from sites $\mathrm{N}-2, \mathrm{~N}-5$, and N-6 have high concentrations of sulfate and high specific conductances; both characteristics are commonly associated with acid mine drainage. The $\mathrm{pH}$ at these three sites remains high, however, probably because of the presence of carbonate strata and better reclamation practices in the eastern part of the basin. Dissolved-sulfate concentrations and specific conductance were lower at site $\mathrm{N}-8$, which is not in a mined area.

\section{Ground Water}

The valley fill along the Muskingum River, especially just downstream from Zanesville, meets the criteria for a shallow, productive aquifer. Acid mine drainage from old or abandoned mines may affect ground-water quality in this area. In addition, the Muskingum River a few miles upstream receives the degraded water of Moxahala Creek. In the same area, the communities of Duncan Falls and Philo draw upon the alluvial source for supply. Therefore, four ground-water sampling sites were chosen in the area (fig. 22).

Water-quality data for four ground-water sites sampled in September 1991 are shown in table 23. Values for $\mathrm{pH}$ ranged from 7.1 to 7.5 , and concentrations of constituents associated with acid mine drainage were not high.

Stiff diagrams (fig. 22) of wells Mu-53, $\mathrm{Mu}-54$, and $\mathrm{Mu}-55$ are indicative of calcium bicarbonate-type waters. In waters from well $\mathrm{Mu}-56$, calcium was the dominant cation; however, both bicarbonate and chloride were major anions. The ground waters sampled in the basin are classified as hard to very hard (table 23). In well Mu-53, alkalinity was considerably lower than hardness; therefore, noncarbonate hardness was substantial in this well. The only OEPA water-quality standard that was not met in any of the wells sampled for the constituents analyzed was the standard for dissolved manganese $(50 \mu \mathrm{g} / \mathrm{L})$ in water from well Mu-56. 
Table 21. Water-quality data for streamwater sites in Middle Muskingum River basin, October 1991

$\left[{ }^{\circ} \mathrm{C}\right.$, degrees Celsius; $\mathrm{ft}^{3} / \mathrm{s}$, cubic feet per second; $\mathrm{mg} / \mathrm{L}$, milligrams per liter, $\mu \mathrm{g} / \mathrm{L}$, micrograms per liter; $\mu \mathrm{S} / \mathrm{cm}$, microsiemens per centimeter at 25 degrees Celsius; --, data not available]

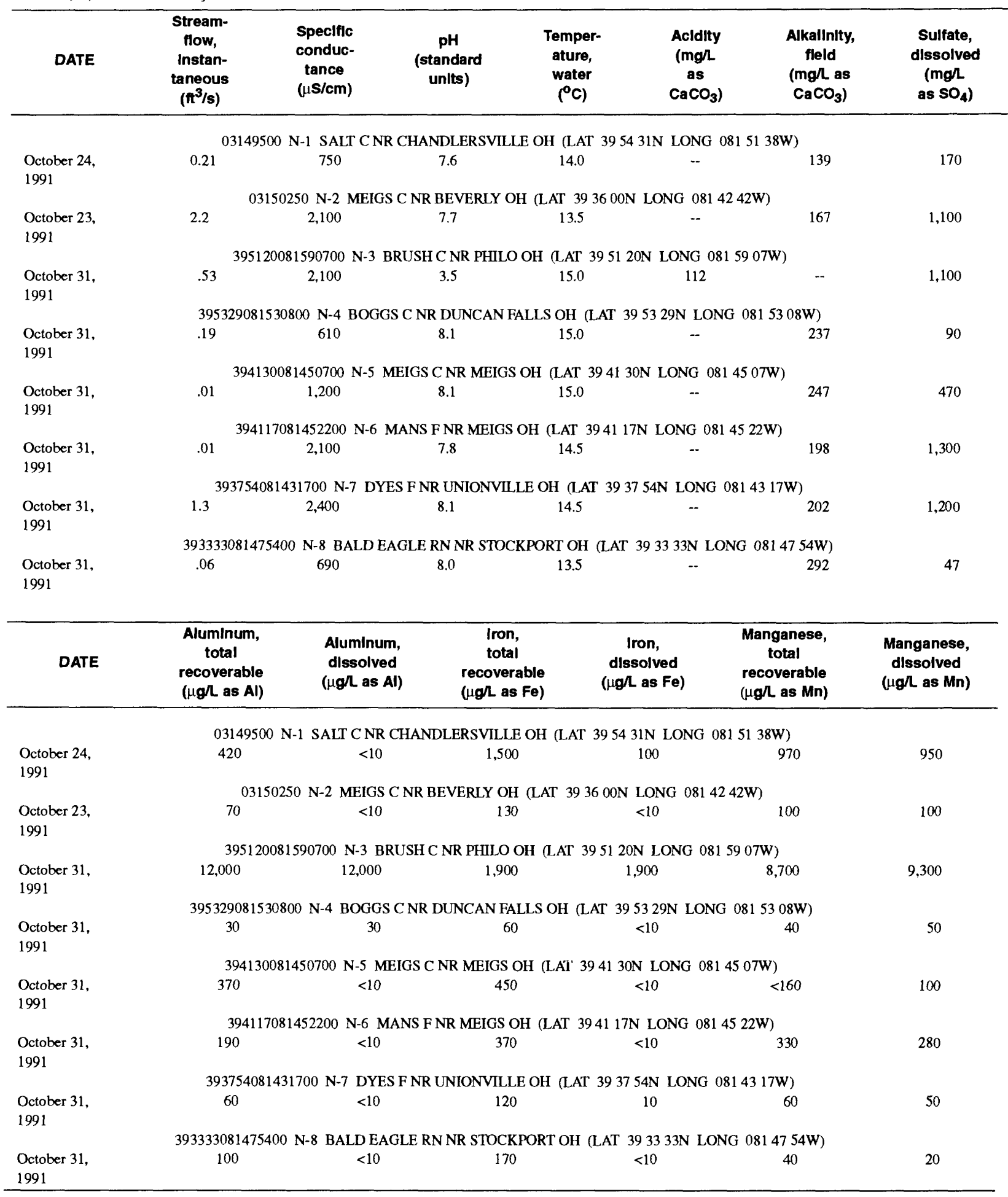


Table 22. Ranges and medians for selected water-quality characteristics for streamwater sites in Middle Muskingum River basin, October 1991

[mg/L, milligrams per liter; $\mu \mathrm{g} / \mathrm{L}$, micrograms per liter; $\mu \mathrm{S} / \mathrm{cm}$, microsiemens per centimeter at 25 degrees Celsius]

\begin{tabular}{|c|c|c|c|}
\hline $\begin{array}{l}\text { Property or } \\
\text { constituent }\end{array}$ & Range & $\begin{array}{l}\text { Locations }^{a} \\
\text { (fig. 22) }\end{array}$ & Median \\
\hline $\begin{array}{l}\text { Specific conductance, } \\
\text { in } \mu \mathrm{S} / \mathrm{cm}\end{array}$ & $\begin{array}{l}610 \text { to } 2,400 \\
3.5 \text { to } 8.1\end{array}$ & $\begin{array}{l}\text { N-4; N-7 } \\
\text { N-3; N-4, 5, } 7\end{array}$ & $\begin{array}{r}1,650 \\
7.9\end{array}$ \\
\hline $\begin{array}{l}\text { Alkalinity, in } \mathrm{mg} / \mathrm{L} \\
\text { as } \mathrm{CaCO}_{3}\end{array}$ & 139 to 292 & $\mathrm{~N}-2 ; \mathrm{N}-8$ & $b_{202}$ \\
\hline $\begin{array}{l}\text { Sulfate, dissolved, } \\
\text { in } \mathrm{mg} / \mathrm{L} \text { as } \mathrm{SO}_{4}-{ }^{----} \\
\text {Aluminum, total, }\end{array}$ & 47 to 1,300 & N-8; N-6 & 785 \\
\hline $\begin{array}{l}\text { in } \mu \mathrm{g} / \mathrm{L} \text { as } \mathrm{Al}-\mathrm{--}-\mathrm{-} \\
\text { Aluminum, dissolved, }\end{array}$ & 30 to 12,000 & $\mathrm{~N}-4 ; \mathrm{N}-3$ & 155 \\
\hline $\begin{array}{l}\text { in } \mu \mathrm{g} / \mathrm{L} \text { as } \mathrm{A} 1 \text {-...- } \\
\text { Iron, total, }\end{array}$ & $<10$ to 12,000 & Several sites; N-3 & $<10$ \\
\hline $\begin{array}{l}\text { in } \mu \mathrm{g} / \mathrm{L} \text { as } \mathrm{Fe} \text {---.-- } \\
\text { Iron, dissolved, }\end{array}$ & 60 to 1,900 & $\mathrm{~N}-4 ; \mathrm{N}-3$ & 270 \\
\hline $\begin{array}{l}\text { in } \mu \mathrm{g} / \mathrm{L} \text { as } \mathrm{Fe} \\
\text { Manganese, total, }\end{array}$ & $<10$ to 1,900 & Several sites; N-3 & $<10$ \\
\hline $\begin{array}{l}\text { in } \mu \mathrm{g} / \mathrm{L} \text { as } \mathrm{Mn}-\mathrm{-}-- \\
\text { Manganese, dissolved, }\end{array}$ & 40 to 8,700 & $\mathrm{~N}-4,8 ; \mathrm{N}-3$ & 135 \\
\hline in $\mu \mathrm{g} / \mathrm{L}$ as $\mathrm{Mn}$ & 20 to 9,300 & N-8; N-3 & 100 \\
\hline
\end{tabular}

a Sites at which the minimum values in the ranges were measured are to the left of the semicolon. Sites at which the maximum values in the ranges were measured are to the right of the semicolon.

b Median was calculated on the basis of only those samples for which alkalinity could be measured (see "Methods," p. 14). 


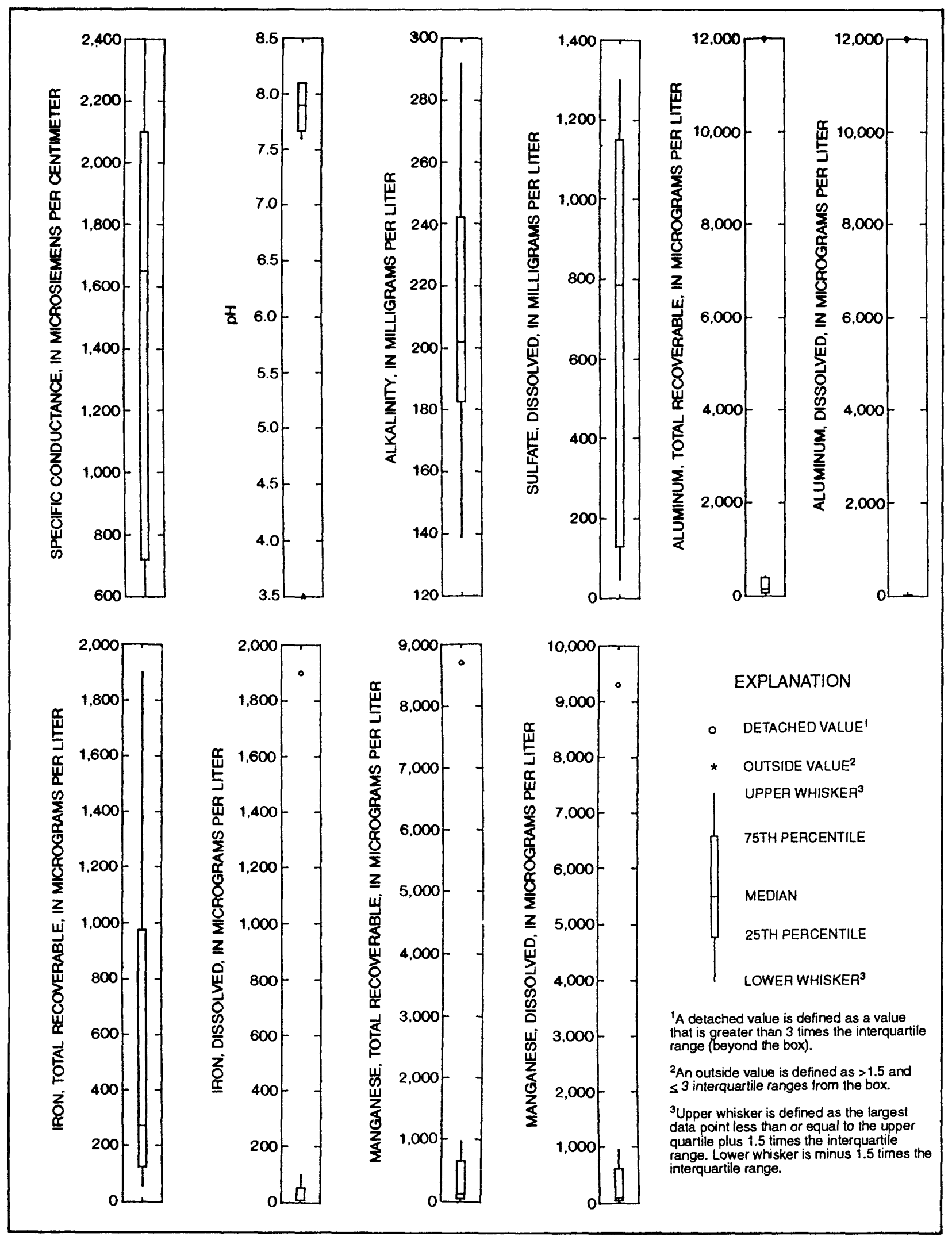

Figure 23.--Ranges, percentiles, and medians of constituents at eight streamwater sites in the Middle Muskingum River basin. 


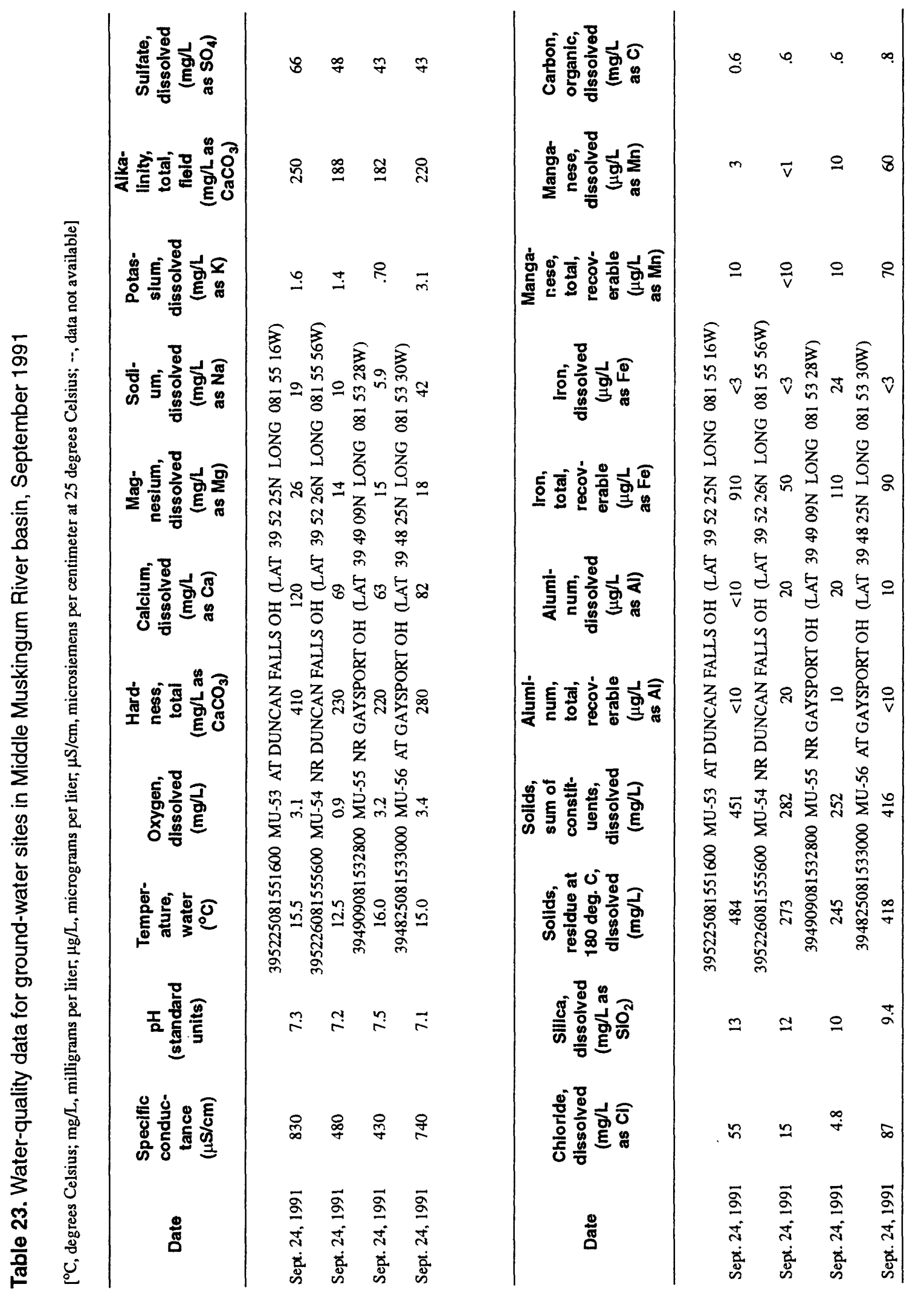




\section{Middle Hocking River Basin}

The Middle Hocking River basin drains an area of $484 \mathrm{mi}^{2}$ (fig. 1, basin Q). It is the same area referred to as "Hocking River Basin (middle portion)" in the ODNR Water Inventory Plan series (Walker, 1958a). It includes approximately the southern quarter of Perry County, the eastern third of Hocking County, the northwestern half of Athens County, and a small part of Morgan County (fig. 24). The upper end of the basin begins just west of Logan, where drainage from the Upper Hocking River basin (fig. 1, basin P) enters the Middle Hocking River basin. Elsewhere, all drainage to the Hocking River is from within the basin. The Hocking River, as the principal stream, traverses the basin from northwest to southeast. The downstream limit of the basin extends a few miles east of Athens to, but does not include, the tributary basin of Strouds Run.

The Middle Hocking River basin is entirely within the Unglaciated Allegheny Plateau Section of the Appalachian Plateaus Physiographic Province. The northern border of the basin is only a few miles from the southern limit of Illinoian glaciation, and is further from the last major glacial advance (Wisconsinan). The basin, however, was affected by glaciation to the extent that outwash deposits from the Illinoian and Wisconsinan stages have been mapped in parts of Athens County (Sturgeon and Associates, 1958).

The Middle Hocking River basin is an upland area through which the Hocking River has cut a meandering 34-mile-long path. The valley floor is at least $1 / 4 \mathrm{mi}$ wide and is several times as wide in some places. The flat to rolling terrain in the main valley extends for several miles upstream in some of the largest tributary valleys in the basin. Local relief, although gentle in the valley bottoms, can be as great as $350 \mathrm{ft}$ between the upland surface and valley floors.

\section{Geologic Setting}

The stratigraphic succession begins at the northwestern end of the basin with sandstones and shales of the Cuyahoga and Logan Formations of Mississippian age. The succession continues to the southeast with sandstones, shales, and coal beds of Pennsylvanian age. Strata of the Pottsville Formation are exposed in Perry County and Hocking County and along the Hocking River valley in northwestern Athens County. Outcrops of coal-bearing strata of the Allegheny Formation are extensive in Perry and Hocking Counties. In Athens County, the Allegheny is exposed in stream valleys along the western tier of townships. Just east of Athens and generally along a north-south line, exposed remnants of basal Monongahela Formation are present.

As of 1989 , coal was produced at several surface-mining sites in the Middle Hocking basin (Lopez, 1991). The output, which amounted to about 1.25 percent of the State's total, was derived largely from the Middle Kittanning (No. 6) and Lower Freeport (No. 6A) coals, but some was also from the Lower Kittanning (No. 5) and Upper Freeport (No. 7) coals. Much of the basin was formerly mined. Locations of areas covered by mining permits, which are presumably active, are scattered around the northwestern half of the basin. One permit was in effect (as of 1991) for mining the Pittsburgh (No. 8) coal in the Monongahela Formation in what is otherwise an area barren of coal south of Athens.

Bedrock sources of ground water with possible yields to wells of 5 to $25 \mathrm{gal} / \mathrm{min}$ had been reported for the northwestern half of the basin (Walker, 1958a). The accumulation of additional well data served to revise this expectation downward to less than $2 \mathrm{gal} / \mathrm{min}$ for Athens County (Schmidt, 1985). A recent evaluation of adjacent parts of Hocking and Perry Counties is currently (1993) in preparation at ODNR. According to Norris and Mayer (1982), the Black Hand Sandstone and 


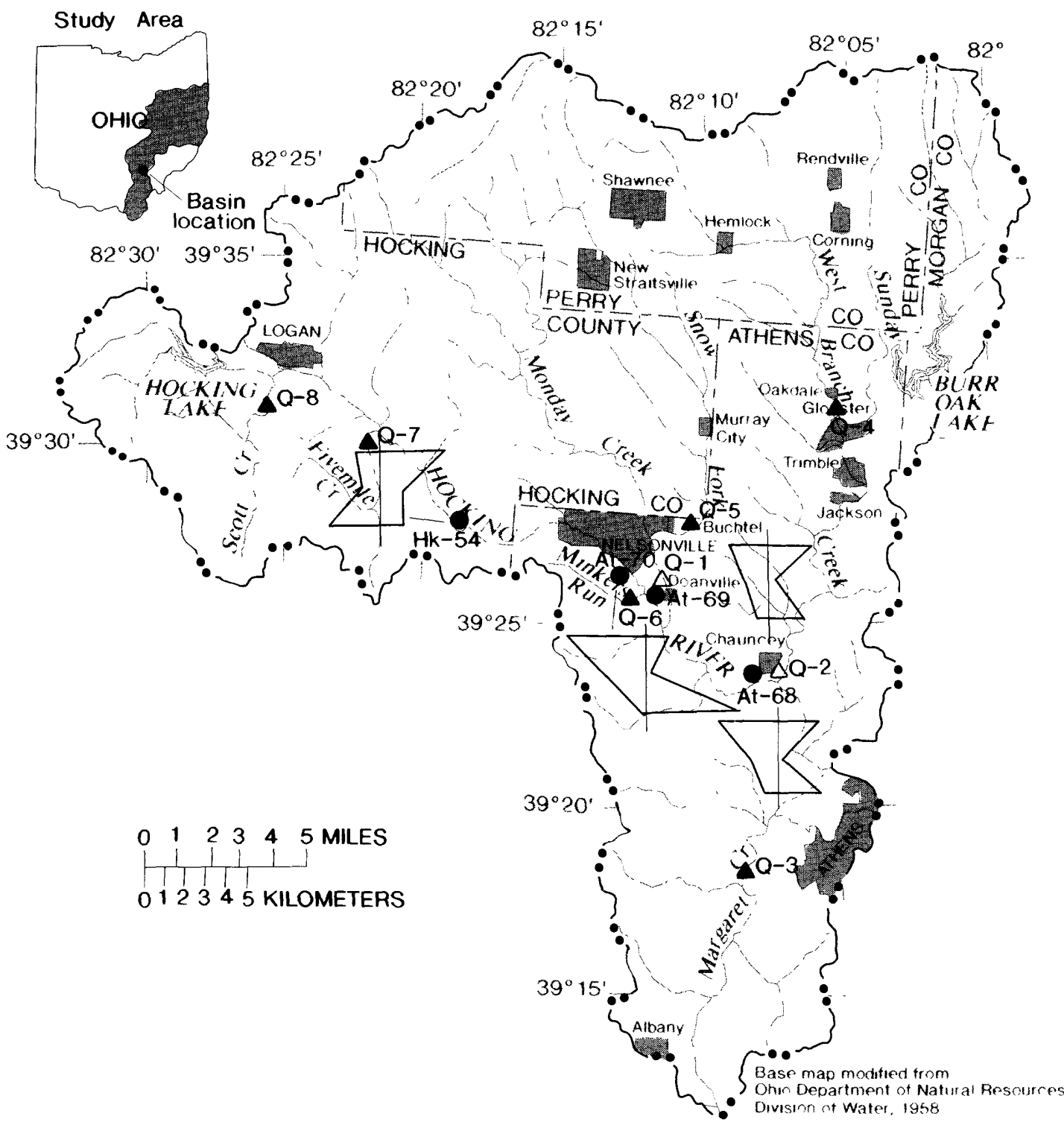

\section{EXPLANATION}

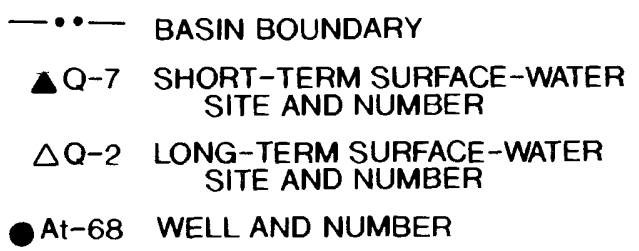

DIAGRAM SHOWING CONCENTRATIONS OF CATIONS AND ANIONS

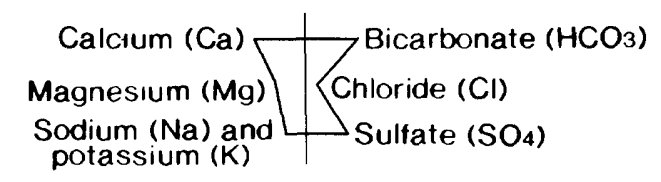

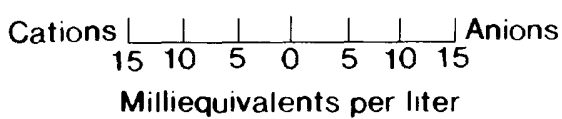

Figure 24.--Middle Hocking River basin (Q), streamwater sites, ground-water sites, and Stiff diagrams for ground-water sites. 
other sandy members of the Mississippian rocks section west of Athens County at the upper end of the basin can be used as a supply of ground water.

In contrast, the unconsolidated sediments forming the valley fill along the Hocking River are ample sources of supply for industrial and municipal purposes. Unconsolidated deposits are present along parts of the tributary systems, but, for the most part, yields to wells are substantially less than those along the Hocking River.

\section{Water Quality}

Two long-term sites and six short-term sites were chosen to assess streamwater quality in the Middle Hocking River basin. Four ground-water sites selected for sampling were in the Hocking River valley near Logan and Chauncey.

The streamwater sites listed in the table on the next page were sampled in early November 1991. Their locations are shown in figure 24.

Two long-term streamwater sites were used to assess water quality in two important tributary systems that drain coal-mining areas. These were on Monday Creek at Doanville (fig. 24, site Q-1) and on Sunday Creek at Chauncey (fig. 24, site Q-2).

The results of synoptic sampling of the streams show different degrees of waterquality degradation. Water from sites Q-1, Q-2, Q-5, and Q-6 had low $\mathrm{pH}$ and high acidity (table 24), indicative of water affected by acid mine drainage. Degradation of water quality at these sites was further shown by high concentrations of dissolved sulfate and total recoverable and dissolved aluminum, iron, and manganese. In contrast, at site Q-4, pH was slightly acidic, alkalinity was low, and sulfate concentration was high $(440 \mathrm{mg} / \mathrm{L})$. Values of $\mathrm{pH}$ at sites Q-3, Q-7, and Q-8 ranged from 7.0 to 7.4. Concentrations of total recoverable or dissolved manganese ranged from 3,400 to $4,700 \mu \mathrm{g} / \mathrm{L}$ at sites Q-3 and Q-8; concentrations of total recoverable iron also were high. At site Q-7, concentrations of constituents associated with acid mine drainage were not high.

The medians for specific conductance and dissolved and total recoverable aluminum, iron, and manganese were high in waters of the Middle Hocking River basin (table 25). The median $\mathrm{pH}, 5.0$, is indicative of the four sites with acidic waters. Box plots show the wide range of values; for example, outside values are shown for aluminum concentration, and detached values are shown for iron concentration (fig. 25). Because there were fewer than five sites for which alkalinity or acidity could be determined, box plots for these characteristics were not constructed.

In general, results of the synoptic sampling of the streams were consistent, considering location of each site with respect to areas of mining. Sites Q-1, Q-2, Q-5, and Q-6 are 11 downstream from areas of past and current mining of Allegheny coals. Site Q-4 is downstream from coal-bearing areas, and waterquality analyses indicate some effect from acid mine drainage. The three sites where $\mathrm{pH}$ is neutral, Q-3, Q-7, and Q-8, are located where little coal has been produced. 


\begin{tabular}{lclc}
\hline $\begin{array}{c}\text { Map index } \\
\text { number }\end{array}$ & Site type & \multicolumn{1}{c}{ Site name } & $\begin{array}{c}\text { Drainage area } \\
\text { (square miles) }\end{array}$ \\
\hline & & & \\
Q-1 & Long term & Monday C at Doanville & 114 \\
Q-2 & do. & Sunday C at Chauncey & 139 \\
Q-3 & Short term & Margaret C nr Athens & 44.2 \\
Q-4 & do. & WB Sunday C nr Oakdale & 34.3 \\
Q-5 & do. & Snow F Monday C at Buchtel & 24.4 \\
Q-6 & do. & Minkers Run nr Nelsonville & 5.2 \\
Q-7 & do. & Fivemile C nr Logan & 12.5 \\
Q-8 & do. & Scott C nr Logan & 21.5 \\
\hline
\end{tabular}

\section{Ground Water}

The unconsolidated deposits along the Hocking River constitute a shallow, productive aquifer. Parts of the Hocking River valley aquifer system are joined by tributary streams with similar unconsolidated deposits that are used for domestic and public supply. Therefore, four wells were sampled in this area.

Water-quality data for four ground-water sites sampled in September 1991 are shown in table 26. Values for $\mathrm{pH}$ ranged from 7.3 to 7.5. Concentrations of total recoverable and dissolved iron were greater than $1,000 \mu \mathrm{g} / \mathrm{L}$ at sites At-68, At-70, and Hk-54. The highest dissolved-sulfate concentration was found at site At-70 (470 mg/L).

Stiff diagrams show the heterogeneous ionic character of water from the four wells sampled in the basin (fig. 24). Calcium and magnesium were major cations in all four wells; sodium was dominant in well $\mathrm{Hk}-54$ and minor in well At-70. As for anions, bicarbonate and sulfate were dominant, although, in well Hk-54, chloride was also important. The waters from the four wells are classified as hard to very hard.
The OEPA water-quality standards for public supplies for dissolved solids $(500 \mathrm{mg} / \mathrm{L})$, iron $(300 \mu \mathrm{g} / \mathrm{L})$, and manganese $(50 \mu \mathrm{g} / \mathrm{L})$ were not met in samples from wells Hk-54, At-68, and At-70. In addition, the standard for dissolved sulfate was not met in samples from well At-70. Water from well At-69 met all of the OEPA standards among the constituents analyzed for.

\section{Leading Creek Basin}

The Leading Creek basin, with a drainage area of $151 \mathrm{mi}^{2}$, includes the western third of Meigs County and small parts of Athens and Gallia Counties (fig. 1, basin QQ). The Leading Creek basin, as defined in this report, is described in the Ohio Water Plan Inventory series (Walker, 1958b) as including part of the Shade River and Leading Creek basins. Leading Creek enters the Ohio River near Middleport (fig. 26). 
Table 24. Water-quality data for streamwater sites in Middle Hocking River basin, October-November 1991

$\left[{ }^{\circ} \mathrm{C}\right.$, degrees Celsius; $\mathrm{ft}^{3} / \mathrm{s}$, cubic feet per second; $\mathrm{mg} / \mathrm{L}$, milligrams per liter, $\mu \mathrm{g} / \mathrm{L}$, micrograms per liter; $\mu \mathrm{S} / \mathrm{cm}$, microsiemens per centimeter at 25 degrees Celsius; --, data not available]

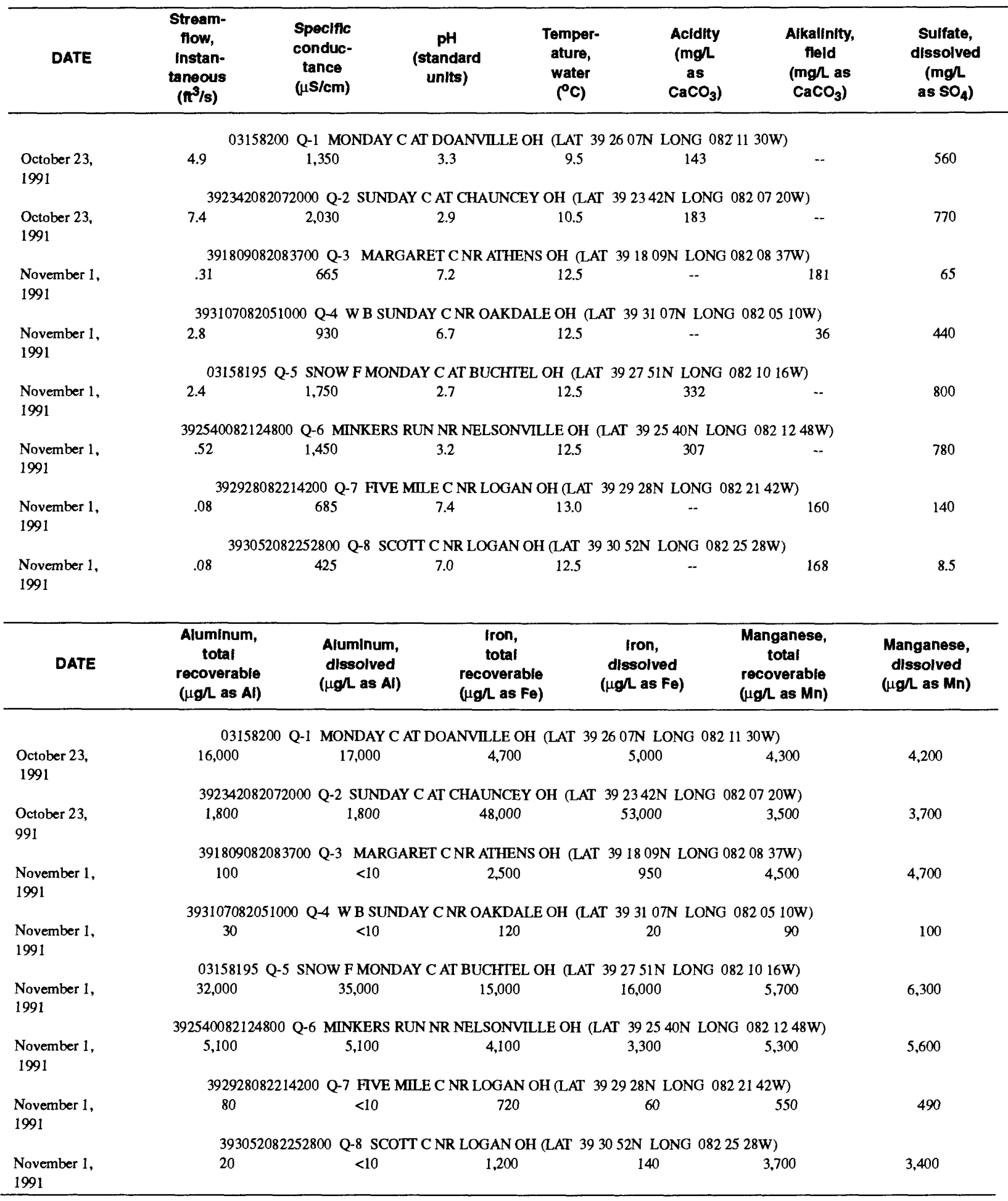


Table 25. Ranges and medians for selected water-quality characteristics for streamwater sites in Middle Hocking River basin, October-November 1991

[mg/L, milligrams per liter; $\mu \mathrm{g} / \mathrm{L}$, micrograms per liter, $\mu \mathrm{S} / \mathrm{cm}$, microsiemens per centimeter at 25 degrees Celsius]

\begin{tabular}{|c|c|c|c|c|}
\hline $\begin{array}{l}\text { Property or } \\
\text { constituent }\end{array}$ & Range & $\begin{array}{l}\text { Locations }^{a} \\
\text { (fig. 24) }\end{array}$ & Median & \\
\hline $\begin{array}{l}\text { Specific conductance, } \\
\quad \text { in } \mu \mathrm{S} / \mathrm{cm}-\end{array}$ & $\begin{array}{l}425 \text { to } 2,030 \\
2.7 \text { to } 7.4\end{array}$ & $\begin{array}{l}\text { Q-8; Q-2 } \\
\text { Q-5; Q-7 }\end{array}$ & $\begin{array}{r}1,140 \\
5.0\end{array}$ & - \\
\hline $\begin{array}{l}\text { Acidity, in } \mathrm{mg} / \mathrm{L} \\
\text { as } \mathrm{CaCO}_{3}\end{array}$ & 143 to 332 & Q-1; Q-5 & $b_{245}$ & \\
\hline $\begin{array}{l}\text { Alkalinity, in } \mathrm{mg} / \mathrm{L} \\
\text { as } \mathrm{CaCO}_{3} \\
\text { Sulfate dissolved }\end{array}$ & 36 to 181 & Q-4; Q-3 & $b_{164}$ & \\
\hline $\begin{array}{l}\text { in } \mathrm{mg} / \mathrm{L} \text { as } \mathrm{SO}_{4} \\
\text { Aluminum, total, }\end{array}$ & 8.5 to 800 & Q-8; Q-5 & 500 & \\
\hline $\begin{array}{l}\text { in } \mu \mathrm{g} / \mathrm{L} \text { as } \mathrm{Al}- \\
\text { Aluminum, dissolved, }\end{array}$ & 20 to 32,000 & Q-8; Q-5 & 950 & \\
\hline $\begin{array}{l}\text { in } \mu \mathrm{g} / \mathrm{L} \text { as } \mathrm{A} 1 \text {-..-- } \\
\text { Iron, total, }\end{array}$ & $<10$ to 35,000 & Several sites; Q-5 & 900 & \\
\hline $\begin{array}{l}\text { in } \mu \mathrm{g} / \mathrm{L} \text { as } \mathrm{Fe}- \\
\text { Iron, dissolved, }\end{array}$ & 120 to 48,000 & Q-4; Q-2 & 3,300 & \\
\hline in $\mu \mathrm{g} / \mathrm{L}$ as $\mathrm{Fe}-$ & 20 to 53,000 & Q-4; Q-2 & 2,125 & \\
\hline $\begin{array}{l}\text { Manganese, total, } \\
\text { in } \mu \mathrm{g} / \mathrm{L} \text { as Mn---.- } \\
\text { Manganese, dissolved, }\end{array}$ & 90 to 5,700 & Q-4; Q-5 & 4,000 & \\
\hline in $\mu \mathrm{g} / \mathrm{L}$ as $\mathrm{Mn}-\cdots$ & 100 to 6,300 & Q-4; Q-5 & 3,950 & \\
\hline
\end{tabular}

a Sites at which the minimum values in the ranges were measured are to the left of the semicolon. Sites at which the maximum values in the ranges were measured are to the right of the semicolon.

b Median was calculated on the basis of only those samples for which alkalinity and acidity could be measured (see "Methods," p. 14). 


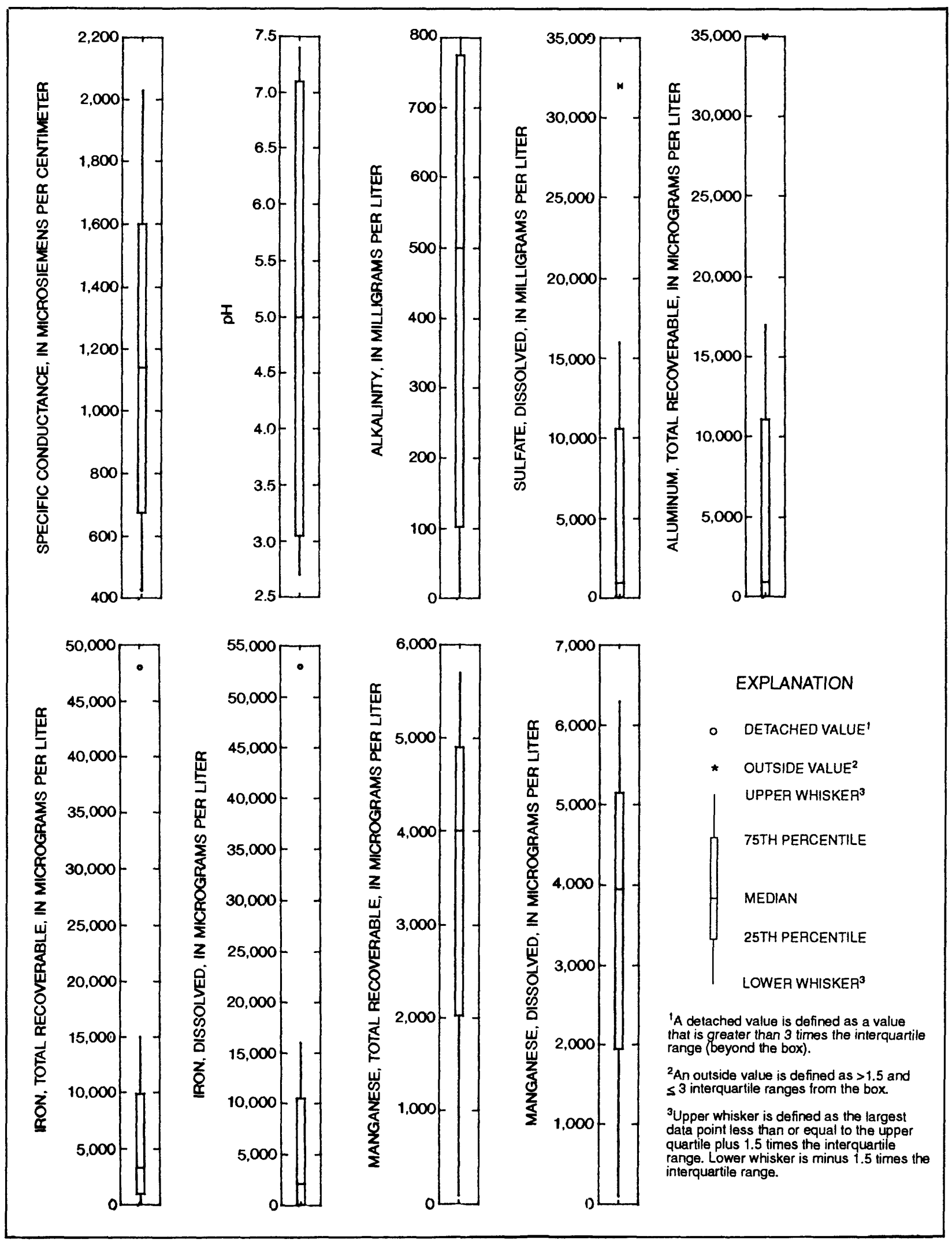

Figure 25.--Ranges, percentiles, and medians of constituents at eight streamwater sites in the Middle Hocking River basin. 


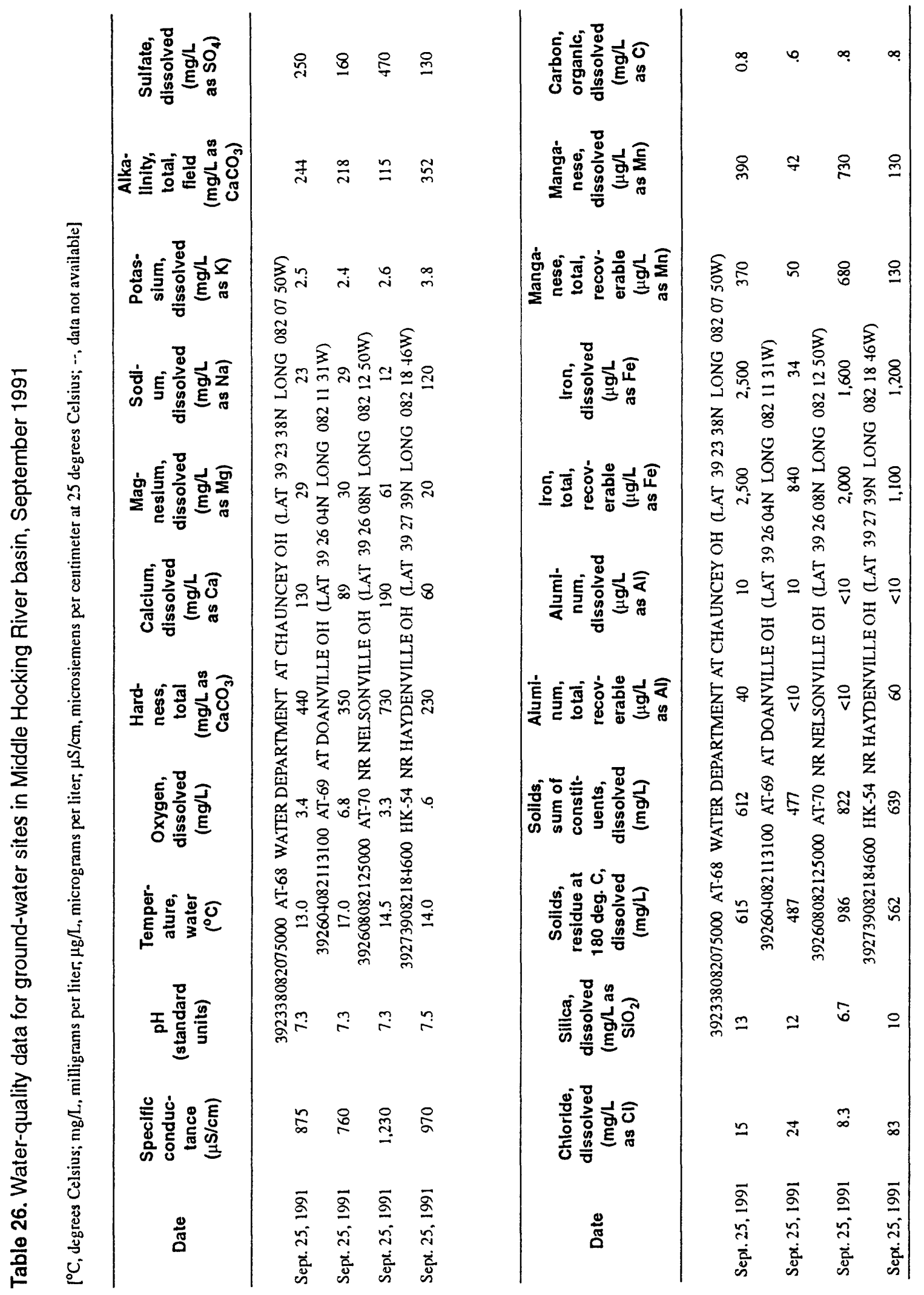




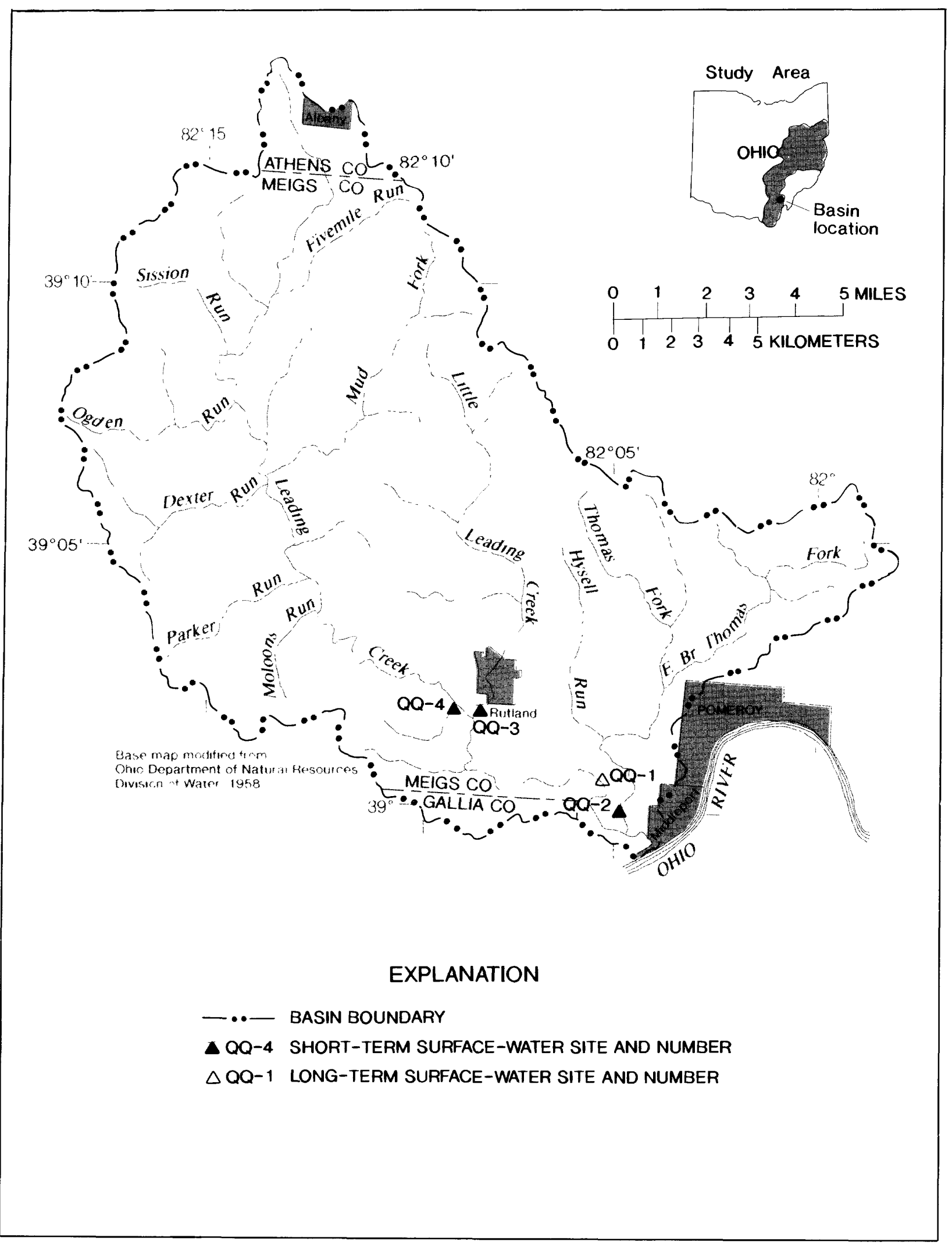

Figure 26.--Leading Creek basin (QQ) and streamwater sites. 
Leading Creek basin is beyond the glaciated part of Ohio and is thus entirely within the Allegheny Plateau Section of the Appalachian Plateaus Physiographic Province. The upland is thoroughly dissected, and Leading Creek, the principal stream, has formed a meandering path across the basin. In places, the valley bottoms are a $1 / 4 \mathrm{mi}$ or more wide. The principal stream has not carved a distinctive flood plain that stands in sharp contrast with upland areas as in, for example, the Middle Muskingum River basin. Many of the tributaries to Leading Creek are in relatively broadbottomed valleys. Local relief is rarely greater than $300 \mathrm{ft}$.

\section{Geologic Setting}

The stratigraphic succession at the western edge of the basin begins with the Conemaugh Formation, and, toward the middle, is overlain by small remnants of the Monongahela Formation. At the base is the Pittsburgh (No. 8) coal, and the Pomeroy (No. 8A) coal is not far above. Although permits have been issued for mining of the Nos. 8 and $8 \mathrm{~A}$ in the basin, no production was reported for 1989 (Lopez, 1991). Instead, output from longwall mining of the Clarion (No. 4A) coal underlying the western part of the basin, which amounted to about 2 percent of total output for the State, was the only coal production reported for Meigs County.

Ground-water-resource maps issued by ODNR (Walker, 1958b; Schmidt, 1985) show that, except near the Ohio River, yields to wells from bedrock are very low. Most representative wells yield less than $3 \mathrm{gal} / \mathrm{min}$. The downstream end of Leading Creek meanders through the Ohio River flood plain, which is underlain by sands and gravels that yield as much as $1,000 \mathrm{gal} / \mathrm{min}$; however, this is a very small part of the basin.

\section{Water Quality}

Because of the small size of the basin, only one long-term streamwater site and three short-term synoptic sites were used for data collection. The only shallow, productive aquifers in the basin are Ohio Valley aquifers. Because Ohio Valley aquifers are not within the scope of this study, no ground-waterquality data were collected in the Leading Creek basin.

The streamwater sites listed in the table on the next page were sampled in early November 1991. Their locations are shown in figure 26.

At sites QQ-1 and QQ-4, specific conductances were greater than $5,000 \mu \mathrm{S} / \mathrm{cm}$, concentrations of dissolved sulfate were greater than $2,000 \mathrm{mg} / \mathrm{L}$, and concentrations of total recoverable and dissolved manganese were greater than $2,000 \mu \mathrm{g} / \mathrm{L}$ (table 27); however, pH values were in the alkaline range. In contrast, the $\mathrm{pH}$ at site QQ-2 was 3.5, and dissolved-sulfate concentration was $850 \mathrm{mg} / \mathrm{L}$. Concentrations of total recoverable and dissolved aluminum, manganese, and iron were very high at site QQ-2. Among all the basins in the synoptic sample collections, medians for specific conductance, dissolved sulfate, and total recoverable and dissolved manganese were highest in samples from the Leading Creek basin (table 28). Because only four sites were sampled in the Leading Creek basin, box plots were not constructed.

Concentrations of constituents associated with acid mine drainage were high in waters from sites QQ-1, QQ-2, and QQ-4. Alkaline waters at sites QQ-1 and QQ-4 indicate some buffering of streamwaters. At site QQ-3, none of the concentrations of constituents associated with acid mine drainage were high, and $\mathrm{pH}$ was alkaline. 


$\begin{array}{lclc}\text { QQ-1 } & \text { Long term } & \text { Leading } \text { C nr Middleport } & 117 \\ \text { QQ-2 } & \text { Short term } & \text { Thomas F nr Middleport } & 29.2 \\ \text { QQ-3 } & \text { do. } & \text { L Leading C nr Rutland } & 25.0 \\ \text { QQ-4 } & \text { do. } & \text { Leading C nr Rutland } & 89.3\end{array}$

\section{Lower Raccoon Creek Basin}

The Lower Raccoon Creek Basin, with a drainage area of $434 \mathrm{mi}^{2}$, includes the eastern third of Jackson County, half of Gallia County, and small adjacent parts of Meigs and Vinton Counties (fig. 1, basin S). The Lower Raccoon Creek basin, which corresponds to the same area described by Pree (1962b), consists of two principal subbasin drainage areas (fig. 27). Little Raccoon Creek enters Raccoon Creek just south of the town of Vinton in the northwestern part of Gallia County. Upstream from this junction, Raccoon Creek is part of the Upper Raccoon Creek Basin (fig. 1, basin R) described in a previous report (Sedam, 1991). The eastern subbasin includes a $139-\mathrm{mi}^{2}$ area drained by a number of smaller drainage systems and short streams that discharge into the Ohio River. The longest of these streams is Campaign Creek.

All of the Lower Raccoon Creek basin lies in the Unglaciated Allegheny Plateau Section of the Appalachian Plateaus Physiographic Province. Because of differences in rock types (such as those between massive sandstone and clays, shales, or friable sandstones), several erosional cycles have produced a land surface that ranges from a terrain of long ridges and narrow valleys in the eastern part of the basin to a less rugged terrain toward the center of the basin (Stout, 1927). Local relief is about $300 \mathrm{ft}$ in the hilliest parts of the area.

\section{Geologic Setting}

The stratigraphic units that are present in the area include, from west to east in ascending order, (1) basal Pennsylvanian units of the Pottsville and Allegheny Formations, (2) the Conemaugh Formation, which is present in much of the central and eastern part of the basin, and (3) scattered remnants of the Monongahela Formation along the eastern side of the basin. These units dip to the east and south, averaging about $33 \mathrm{ft} / \mathrm{mi}$ to the southeast, according to Stout (1927).

The principal coal-bearing units are the Lower Mercer (No. 3) coal in the Pottsville Formation and the Brookville (No. 4), Clarion (No. 4A), Lower Kittanning (No. 5), Middle Kittanning (No. 6), Lower Freeport (No. 6A), and Upper Freeport (No. 7) coals in the Allegheny Formation (fig. 4). Small units of the Pittsburgh (No. 8) and Pomeroy (No. 8A) coals of the Monongahela Formation are found north and south of Gallipolis. About 3 percent of the State's coal production in 1989 was in the Lower Raccoon Creek basin (Lopez, 1991). Most of this was from the Allegheny Formation in the northwestern part of the basin near the drainage divide between the Upper Raccoon Creek basin and the Lower Raccoon Creek basin. 
Table 27. Water-quality data for streamwater sites in Leading Creek basin, October-November 1991

$\left[{ }^{\circ} \mathrm{C}\right.$, degrees Celsius; $\mathrm{ft}^{3} / \mathrm{s}$, cubic feet per second; mg/L, milligrams per liter; $\mu \mathrm{g} / \mathrm{L}$, micrograms per liter; $\mu \mathrm{S} / \mathrm{cm}$, microsiemens per centimeter at 25 degrees Celsius; --, data not available][

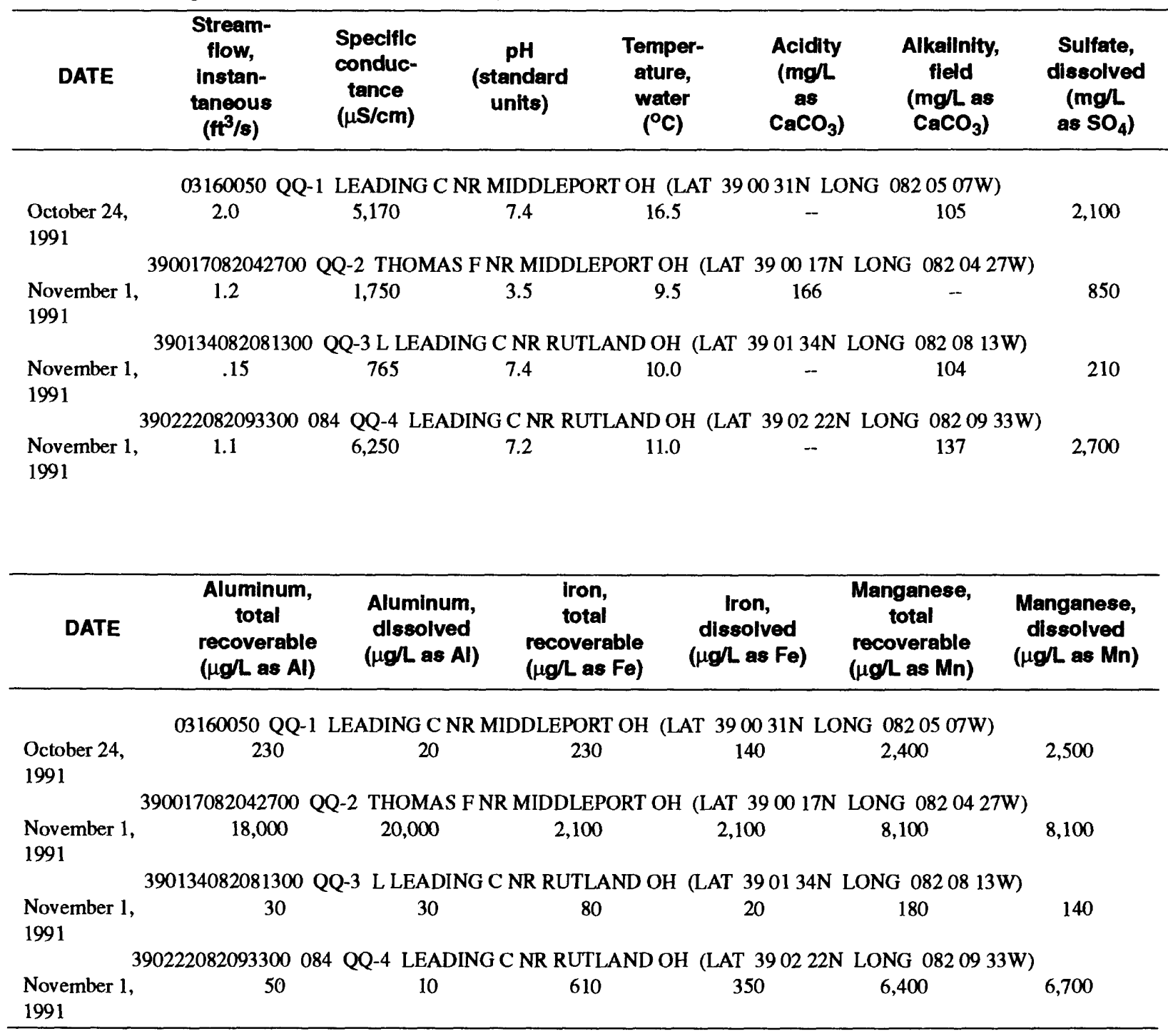


Table 28. Ranges and medians for selected water-quality characteristics for streamwater sites in Leading Creek basin, October-November 1991

[mg/L, milligrams per liter; $\mu \mathrm{g} / \mathrm{L}$, micrograms per liter; $\mu \mathrm{S} / \mathrm{cm}$, microsiemens per centimeter at 25 degrees Celsius]

\begin{tabular}{|c|c|c|c|}
\hline $\begin{array}{l}\text { Property or } \\
\text { constituent }\end{array}$ & Range & $\begin{array}{l}\text { Locations }^{a} \\
\text { (fig. 26) }\end{array}$ & Median \\
\hline $\begin{array}{l}\text { Specific conductance, } \\
\text { in } \mu \mathrm{S} / \mathrm{cm}-\end{array}$ & $\begin{array}{l}765 \text { to } 6,250 \\
35 \text { to } 7.4\end{array}$ & $\begin{array}{l}\text { QQ-3; QQ-4 } \\
\text { QQ-2; QQ-1,3 }\end{array}$ & $\begin{array}{r}3,460 \\
7.3\end{array}$ \\
\hline $\begin{array}{l}\text { Alkalinity, in } \mathrm{mg} / \mathrm{L} \\
\text { as } \mathrm{CaCO} \mathrm{CO}_{3} \\
\text { Sulfate dissolved }\end{array}$ & 104 to 137 & QQ-3; QQ-4 & $\mathrm{b}_{105}$ \\
\hline $\begin{array}{l}\text { Sulfate, dissolved, } \\
\text { in } \mathrm{mg} / \mathrm{L} \text { as } \mathrm{SO}_{4}-\cdots \\
\text { Aluminum, total, }\end{array}$ & 210 to 2,700 & QQ-3; QQ-4 & 1,475 \\
\hline $\begin{array}{l}\text { in } \mu \mathrm{g} / \mathrm{L} \text { as } \mathrm{Al}------ \\
\text { Aluminum, dissolved, }\end{array}$ & 30 to 18,000 & QQ-3; QQ-4 & 140 \\
\hline $\begin{array}{l}\text { in } \mu \mathrm{g} / \mathrm{L} \text { as } \mathrm{A} 1 \text {-.--- } \\
\text { Iron, total, }\end{array}$ & 10 to 20,000 & QQ-4; QQ-2 & 25 \\
\hline $\begin{array}{l}\text { in } \mu \mathrm{g} / \mathrm{L} \text { as } \mathrm{Fe}---{ }^{---} \\
\text {Iron, dissolved, }\end{array}$ & 80 to 2,100 & QQ-3; QQ-2 & 420 \\
\hline $\begin{array}{l}\text { in } \mu \mathrm{g} / \mathrm{L} \text { as } \mathrm{Fe}- \\
\text { Manganese, total, }\end{array}$ & 20 to 2,100 & QQ-3; QQ-2 & 245 \\
\hline $\begin{array}{l}\text { in } \mu \mathrm{g} / \mathrm{L} \text { as } \mathrm{Mn}------ \\
\text { Manganese, dissolved, }\end{array}$ & 180 to 8,100 & QQ-3; QQ-2 & 4,400 \\
\hline in $\mu \mathrm{g} / \mathrm{L}$ as $\mathrm{Mn}$------ & 140 to 8,100 & QQ-3; QQ-2 & 4,600 \\
\hline
\end{tabular}

a Sites at which the minimum values in the ranges were measured are to the left of the semicolon. Sites at which the maximum values in the ranges were measured are to the right of the semicolon.

b Median was calculated on the basis of only those samples for which alkalinity could be measured (see "Methods," p. 14). 


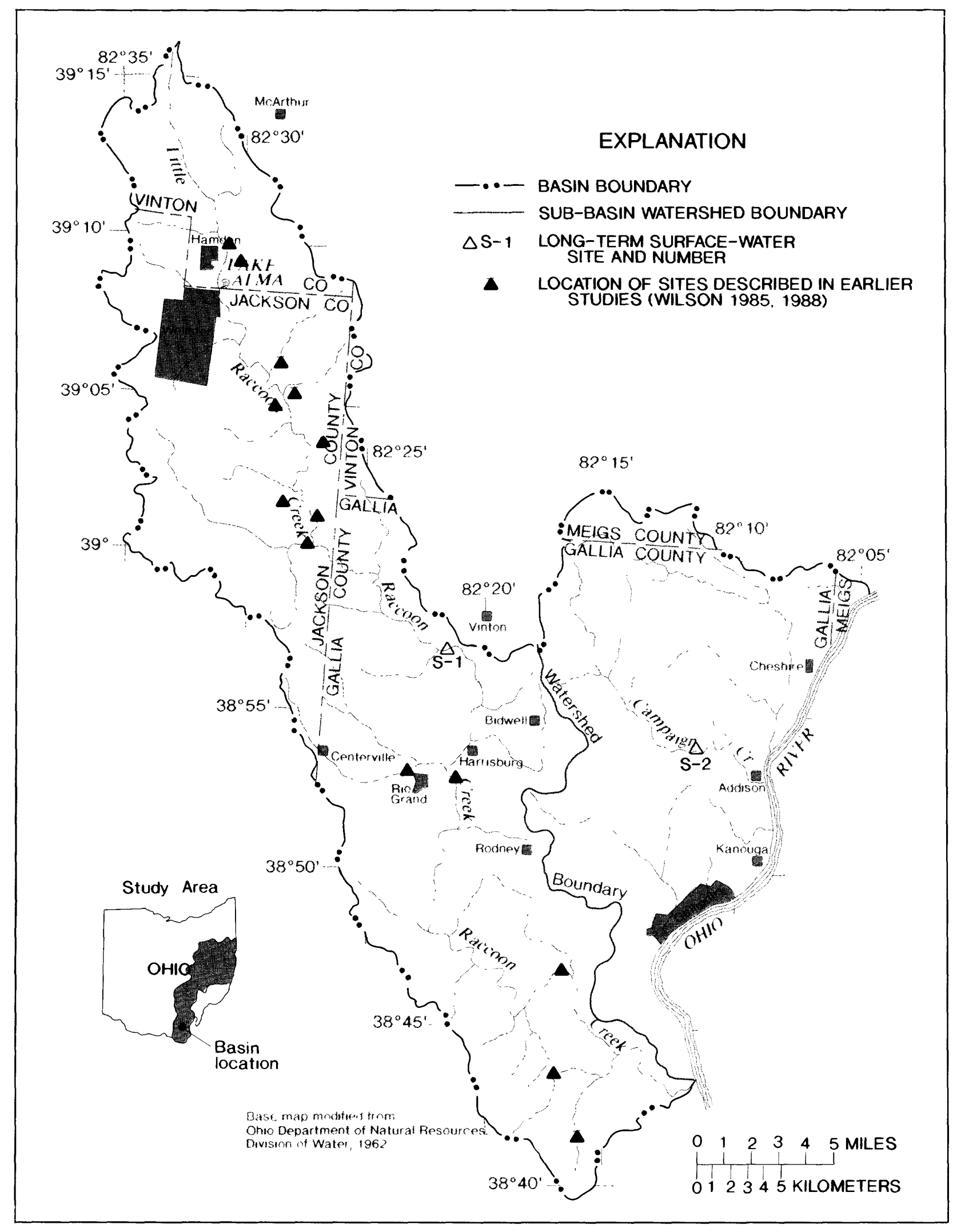

Figure 27.--Lower Raccoon Creek basin (S) and streamwater sites. 
Principal aquifers are in the surficial bedrock. Of regional importance is the Black Hand Sandstone Member of the Cuyahoga Formation, which yields to many wells in Vinton County and a small part of Jackson County. The southeastern limit of potable water in the Black Hand Sandstone Member is generally along a line about $3 \mathrm{mi}$ east of McArthur that extends through Wellston (fig. 27), according to Norris and Mayer (1982). Locally, productive sources of water are available in sandstone units of the Pottsville and Allegheny Formations.

Differences between modern and preglacial drainage systems have been explained in detail by Stout (1927). Alluvial deposits are present along various streams, but these are mostly of fine-grained sand or clay. Shallow ground-water sources in these deposits are productive only for small domestic supplies. In general, most shallow wells in the area are completed in bedrock.

\section{Water Quality}

The Raccoon Creek basin (fig. 1, basins $\mathrm{R}$ and $S$ ) was studied previously by the USGS (Wilson, 1985, 1988), in cooperation with the ODNR, Division of Reclamation. In the 1985 study, data for use in individual subbasin reclamation projects were collected in synoptic sampling of 41 streamwater sites during base flow in November 1983. Fifteen of those sites, including long-term site S-1 used in the current study, were in the Lower Raccoon Creek basin (fig. 1, basin S). The 1988 study includes chemical and biological data collected from July 1984 through September 1986 at some of the 15 sites in support of reclamation projects in selected subbasins. Because these studies provided considerable streamwater data for the Lower Raccoon Creek basin, no short-term streamwater sites were selected in this study. Two long-term streamwater sites were sampled six times during 1989-91. The data are included in table 31 .

Except for two areas along the Ohio River north of Gallipolis, there are no shallow, productive aquifers in the Lower Raccoon Creek basin. Therefore, no ground-water sampling was done in the basin.

\section{SUMMARY OF WATER QUALITY FOR 1985-91}

A principal objective of the investigation was to provide baseline data on the water quality of streams draining Ohio's coal-mining region from 1985-91. The study area included actively mined, unmined, and formerly mined lands. In addition, baseline data were compiled on the quality of ground water in productive, shallow aquifers in the study area.

\section{Streamwater}

Streamwater measurements included periodic sampling of 41 long-term sites selected to provide a general assessment of streamwater quality throughout the 21-basin study area. Water-quality data for 246 samples collected during 1989-91 at these sites are summarized in table 2 and figure 7 . Water-quality data for 508 samples collected at the same sites during 1985-91 are summarized in table 29 and figure 28. The data for the 1987-88 study period were presented by Sedam (1991, p. 16), and data for 1985-86 were presented by Jones (1988, p. 12-13).

For the long-term site network, the medians for the 1989-91 period were very similar to the medians for the two earlier study periods (1985-86 and 1987-88). Therefore, medians did not change substantially over the 7-year study period. 
Table 29. Ranges and medians for selected water-quality characteristics for long-term streamwater sites in active coal-mining areas of Ohio, 1985-91

[mg/L, milligrams per liter; $\mu \mathrm{g} / \mathrm{L}$, micrograms per liter, $\mu \mathrm{S} / \mathrm{cm}$, microsiemens per centimeter at 25 degrees Celsius]

\begin{tabular}{|c|c|c|c|}
\hline $\begin{array}{l}\text { Property or } \\
\text { constituent }\end{array}$ & Range & $\begin{array}{l}\text { Locations }^{a} \\
\text { (fig. 5) }\end{array}$ & Median \\
\hline $\begin{array}{l}\text { Specific conductance, } \\
\text { in } \mu \mathrm{S} / \mathrm{cm}-\mathrm{-}\end{array}$ & $\begin{array}{l}270 \text { to } 5,170 \\
2.7 \text { to } 9.1\end{array}$ & $\begin{array}{l}\text { T-1; QQ-1 } \\
\text { O-2, Q-2; A-1 }\end{array}$ & $\begin{array}{l}770 \\
7.8\end{array}$ \\
\hline $\begin{array}{l}\text { Alkalinity, in mg/L } \\
\text { as } \mathrm{CaCO}_{3}\end{array}$ & 1 to 391 & Q-1; K-1 & $\mathrm{b}_{118}$ \\
\hline $\begin{array}{l}\text { Sulfate, dissolved, } \\
\text { in } \mathrm{mg} / \mathrm{L} \text { as } \mathrm{SO}_{4}\end{array}$ & 13 to 2,100 & J-1; QQ-1 & 200 \\
\hline $\begin{array}{l}\text { Aluminum, total, } \\
\text { in } \mu \mathrm{g} / \mathrm{L} \text { as } \mathrm{Al}------\end{array}$ & $<10$ to 18,000 & P-2, Q-2; Q-1 & 220 \\
\hline $\begin{array}{l}\text { Aluminum, dissolved, } \\
\text { in } \mu \mathrm{g} / \mathrm{L} \text { as } \mathrm{A} 1 \text {-.--- }\end{array}$ & $<10$ to 18,000 & Several sites; Q-1 & 30 \\
\hline $\begin{array}{l}\text { Iron, total, } \\
\quad \text { in } \mu \mathrm{g} / \mathrm{L} \text { as } \mathrm{Fe}-\end{array}$ & 20 to 62,000 & D-3; Q-2 & 630 \\
\hline $\begin{array}{l}\text { Iron, dissolved, } \\
\quad \text { in } \mu \mathrm{g} / \mathrm{L} \text { as } \mathrm{Fe}-\ldots\end{array}$ & $<10$ to 54,000 & Several sites; Q-2 & 50 \\
\hline $\begin{array}{l}\text { Manganese, total, } \\
\quad \text { in } \mu \mathrm{g} / \mathrm{L} \text { as } \mathrm{Mn} \text {--.--- }\end{array}$ & $<10$ to 50,000 & D-3;O-2 & 350 \\
\hline $\begin{array}{l}\text { Manganese, dissolved, } \\
\text { in } \mu \mathrm{g} / \mathrm{L} \text { as } \mathrm{Mn}-\end{array}$ & $<10$ to 47,000 & Several sites; O-2 & 290 \\
\hline
\end{tabular}

a Sites at which the minimum values in the ranges were measured are to the left of the semicolon. Sites at which the maximum values in the ranges were measured are to the right of the semicolon.

b Median was calculated on the basis of only those samples for which alkalinity could be measured (see "Methods," p. 14). 


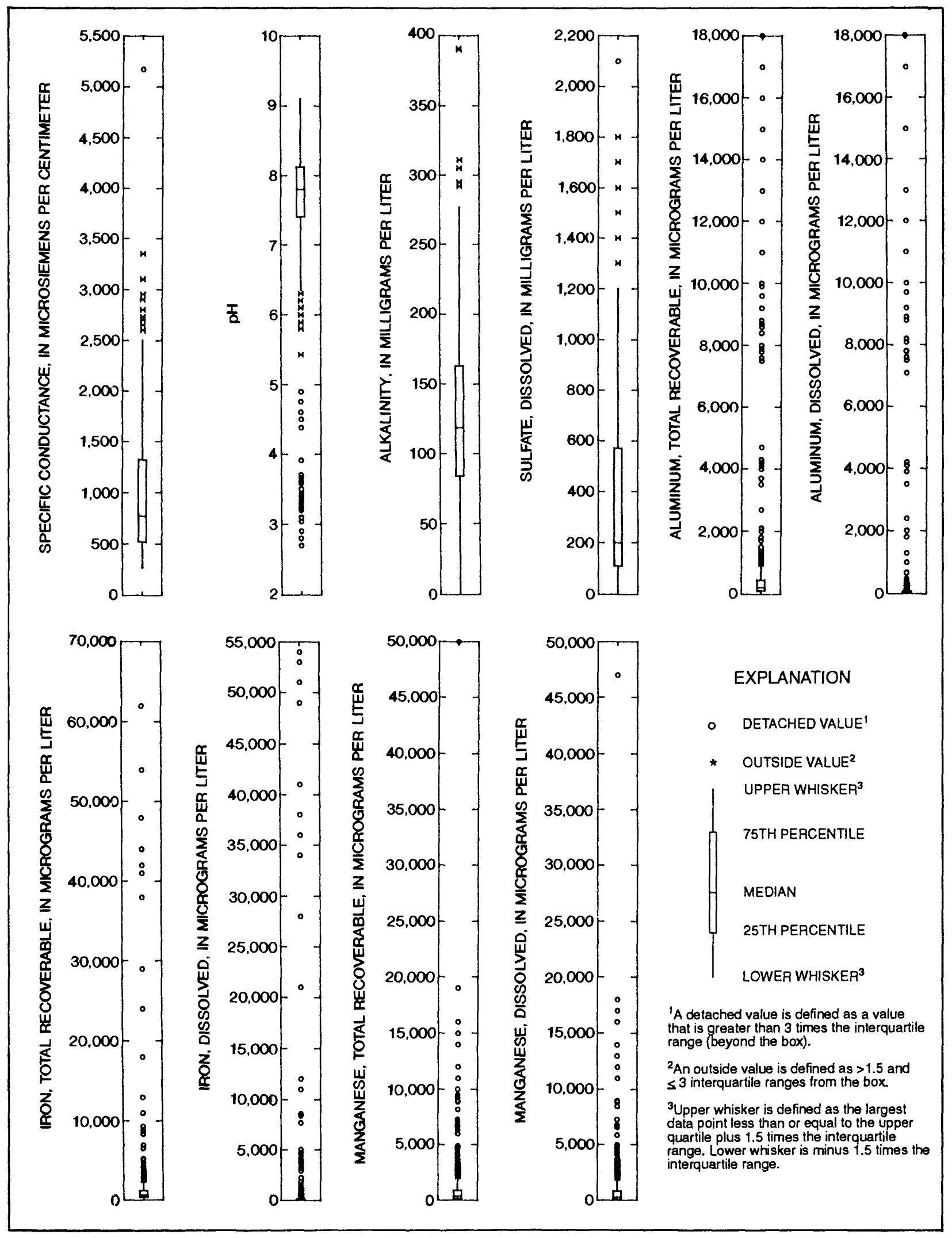

Figure 28.--Ranges, percentiles, and medians of constituents in 508 samples collected at 41 long-term streamwater sites in active coal mining areas of Ohio, 1985-91. 
Throughout the entire study period (1985-91), samples from streamwater at sites in the Moxahala Creek and Middle Hocking River basins (basins $\mathrm{O}$ and $\mathrm{Q}$, respectively) had high concentrations of constituents and low $\mathrm{pH}$ values commonly associated with acid mine drainage. For all three study periods, in streamwater samples from basins $\mathrm{O}$ and $\mathrm{Q}$, concentrations of total recoverable and dissolved aluminum, iron, and manganese were at the top of the range of values, and $\mathrm{pH}$ was at the bottom of the range of values. Before the 1989-91 study, the highest specific conductances and dissolved-sulfate concentrations were found in the Short and Wheeling Creeks basin (basin C). In 1991, however, the highest specific conductances and dissolved-sulfate concentrations for the long-term site network (1985-91) were found in the Leading Creek basin (basin QQ).

Concentrations of total recoverable and dissolved aluminum, iron, and manganese for a number of sites were near or below minimum detection levels at several sites (table 29). At these same sites, specific conductance and dissolved-sulfate concentration were low, and $\mathrm{pH}$ and alkalinity were high; such a combination of characteristics indicates that these waters were probably not affected by mining activities.

Buffering of streamwaters was indicated by samples in which $\mathrm{pH}$ was in the neutral to alkaline range but in which concentrations of one or more of the constituents of interest were high. The basins in which samples in this category were collected include the Yellow and Cross Creeks basin (basin B) and Wheeling Creeks basin (basin C). In these areas, there is an abundance of carbonate rock to serve as a buffering agent.

Water from degraded streams is diluted as the streams discharge into larger streams. Two acidic streams, Monday Creek (site Q-1) and Sunday Creek (site Q-2), discharge into the Hocking River. The $\mathrm{pH}$ of samples collected at the USGS streamflow-gaging station on the
Hocking River at Athens several miles below the confluence of Monday and Sunday Creeks remains high $(\mathrm{pH}>8.0)$, despite drainage from two acidic streams.

Sites along the same stream can differ considerably in water quality. This is shown by the difference in water quality between two sites, P-6 and P-1, along Rush Creek in the Upper Hocking River basin (basin P). The $\mathrm{pH}$ is in the alkaline range for water from site P-1; upstream at site $\mathrm{P}-6$, the $\mathrm{pH}$ is in the acidic range. At site $\mathrm{P}-1$, however, moderately high specific conductances and concentrations of dissolved sulfate and manganese indicate a possible source of degradation upstream.

The variability in water quality of different streams in the same drainage basin demonstrates the importance of proper site selection for identifying problem areas in the coalmining regions. Within individual basins, however, extreme concentrations of certain constituents can be used to identify sources of degradation that might be masked by buffering or downstream dilution.

\section{Ground water}

During the 1985-91 data-collection period, 16 of the 21 study basins were sampled for ground water. Of the 69 wells sampled, 54 yielded from unconsolidated aquifers.

For 20 wells, the ground waters were of the calcium bicarbonate type. Except for a few samples with high concentrations of sodium, calcium was the dominant cation, and magnesium was commonly an important secondary cation. Bicarbonate was the principal anion in many samples, although sulfate was often a major anion and was the dominant anion in waters from several wells. A graphical distribution of the principal cations and anions is shown in figure 29. 


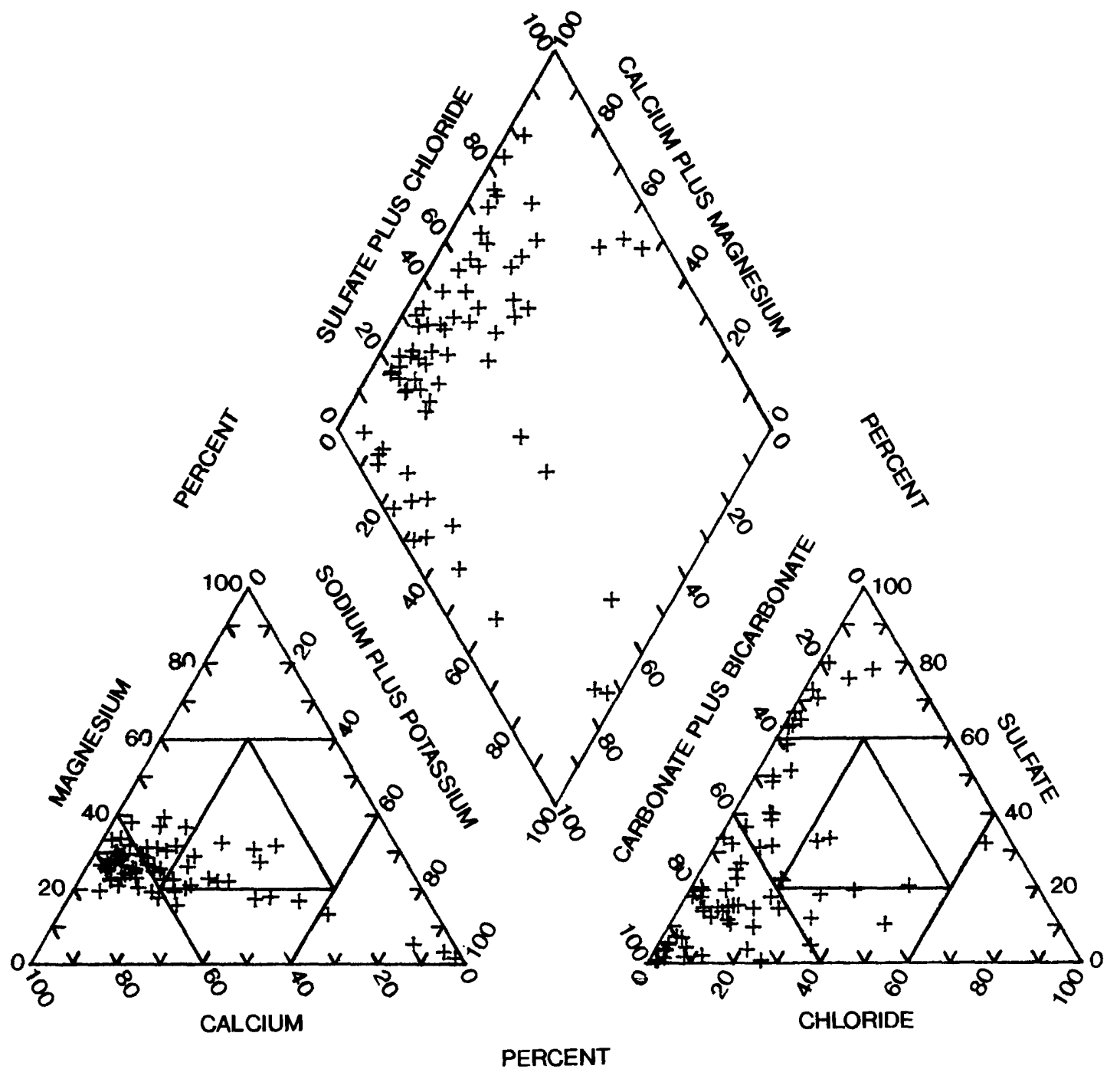

EXPLANATION

+ DATA POINT--Shows cation-anion percentages

based on milliequivalents per liter in water

from sampled well; wells are not

differentiated by study basin

Figure 29.--Piper diagram showing distribution of constituents for ground-water sites sampled in active coal mining ares of Ohio, 1985-91. 
Analytical results of 69 ground-water samples collected during 1985-91 are summarized in table 30. Similar data collected during 1989-91 only are summarized in table 3 . The data for the 1987-88 study period were summarized by Sedam (1991), and 1985-86 ground-water-quality data were summarized by Jones (1988, p. 16-19). Generally, the wells sampled contained hard to very hard waters.

A comparison of water-quality data throughout the 1985-91 study period shows that the medians for most constituents were fairly consistent, considering the geographical diversity of the study area. Concentrations of total recoverable and dissolved iron were exceptions. According to Hem $(1989$, p. 83), however, the concentration of iron in ground water is determined by $\mathrm{pH}$ and dissolved oxygen in the system, which, in turn, is affected by ground-water circulation and mixing. Considering the range of dissolved-oxygen concentration that was observed in the ground-water samples, most of which were derived from unconsolidated sediments, the variations in iron concentration were not unusual.

In an earlier study (Razem and Sedam, 1985), 100 ground-water samples were collected in the same area as for the current study.
The earlier study investigated the groundwater quality of wells drilled into or through a coal bed. Although objectives of the two studies were different, the medians for specific conductance, $\mathrm{pH}$, hardness, calcium, and sulfate were similar in both studies. Slightly different medians were found between the two studies for alkalinity, iron, and manganese.

In general, median specific conductances for ground-water samples were lower than medians for streamwater samples (table 29) for the 1985-91 study period. Median concentrations in ground water were also considerably lower than those in streamwater for dissolved sulfate, and were slightly lower for aluminum and manganese. The $\mathrm{pH}$ of ground water varied little, unlike the $\mathrm{pH}$ of streamwater. Except for a few ground-water sites where concentrations of dissolved sulfate were greater than $250 \mathrm{mg} / \mathrm{L}$ and concentrations of total recoverable and dissolved iron and manganese were greater than $1,000 \mu \mathrm{g} / \mathrm{L}$, the ground-water quality in the study area shows little, if any, effect from mining of coal. 
Table 30. Ranges and medians for selected water-quality characteristics for ground-water sites in active coal-mining areas of Ohio, 1985-91

$[\mathrm{mg} / \mathrm{L}$, milligrams per liter; $\mu \mathrm{g} / \mathrm{L}$, micrograms per liter; $\mu \mathrm{S} / \mathrm{cm}$, microsiemens per centimeter at 25 degrees Celsius.

Some of the values are from Jones (1988) and Sedam (1991)]

\section{Property or} constituent

\section{Range}

\section{Locations $^{\mathrm{a}}$}

(fig. 8)
Median

Specific conductance,

in $\mu \mathrm{S} / \mathrm{cm}$

120 to 1,590

V-90; B-30

640

$\mathrm{pH}$

5.4 to 8.9

C-11; B-28

Oxygen, dissolved, in $\mathrm{mg} / \mathrm{L}$

0.0 to 8.1

Cs-149; Cs-152

1.6

Hardness, in $\mathrm{mg} / \mathrm{L}$ as $\mathrm{CaCO}_{3}$

13 to 840

Hk-53; Hr-23

Noncarbonate hardness, in $\mathrm{mg} / \mathrm{L}$ as $\mathrm{CaCO}_{3}$

0 to 610

Several sites; At-70

Calcium, dissolved, in $\mathrm{mg} / \mathrm{L}$ as $\mathrm{Ca}$

3.4 to 250

Hk-53; Hr-23

1.1 to 64

Hk-53; Co-1

3.5 to 280

Cs-154; B-28

0.6 to 6.8

Mu-50; Tu-50

8 to 461

V-90; B-28

1.0 to 630

Cs-149, Tu-55; B-30

2.1 to 200

Cs-150; Tu-53

6.6 to 38

Tu-55; V-90

Solids, dissolved, sum of constituents, in $\mathrm{mg} / \mathrm{L}$

100 to 1,140

V-90; B-30

10 to 600

Several sites; $\mathrm{Hr}-30$

20

$<10$ to 100

Many sites; $\mathrm{Hr}-25,32$

$<10$

10 to 9,800

Cs-154; Pe-58

890

3 to 8,700

Several sites; Tu-57

580

10 to 3,200

Several sites; Co-1

90

1 to 3,200

Cs-154, 155; Co-1

85

0.5 to 3.1

Several sites; Mu-50

.8

\footnotetext{
a Sites at which the minimum values in the ranges were measured are to the left of the semicolon. Sites at which the maximum values in the ranges were measured are to the right of the semicolon.
} 


\section{SUMMARY AND CONCLUSIONS}

Coal is Ohio's most economically important mineral resource. Even with the passage of legislation to control mining activities, many abandoned mines are still in need of restoration. Mining activities could affect water quality in the mining regions of southeastern Ohio and remain a potential threat in unmined areas. Therefore, natural-resource managers in Ohio found a need for baseline hydrologic data to facilitate the processing of coal-mining permits in unmined areas and in active areas of mining.

A 7-year study was done in three phases to collect baseline water-quality data in the coalmining region of eastern Ohio. A long-term network of streamwater sites was established in 21 drainage basins, and periodic sampling was done during 1985-91 to assess baseline streamwater quality. This sampling was supplemented by synoptic data collections at short-term and long-term streamwater and short-term ground-water sites in three basins each year.

This report presents data from the 1989-91 sampling period and includes a summary for the entire study (1985-91). Two previous reports present data collected during 1985-86 (Jones, 1988) and during 1987-88 (Sedam, 1991). All three reports include discussions of geologic setting and physiography in the study basins.

Several physical properties and chemical constituents were measured to assess the water quality of major streams in the study area. These were specific conductance, $\mathrm{pH}$, alkalinity, and (or) acidity, and concentrations of dissolved sulfate and total recoverable and dissolved iron, manganese, and aluminum. Additional constituents and physical properties were measured to assess the ground-water quality. These included hardness and concentrations of dissolved solids, calcium, sodium, potassium, and chloride.
During 1989-91, 246 samples from the long-term streamwater network were analyzed to assess baseline water quality. Water samples from sites in the Middle Hocking River basin and Moxahala Creek basin had low pH, typical of streams affected by mining activities. These samples also had high concentrations of many constituents commonly associated with acid mine drainage, including dissolved sulfate, and total recoverable and disssolved iron, manganese, and aluminum. Water from some other sites in the long-term site network also had high concentrations of these consitituents, but $\mathrm{pH}$ was in the neutral to alkaline range, indicating buffering of streamwaters.

During the final phase of the study (1989-91), short-term and long-term streamwater sites in nine basins were selected for synoptic sampling. Low $\mathrm{pH}$ and high concentrations of certain constituents associated with acid mine drainage were not found in Lower Wills Creek basin. In the Yellow and Cross Creek, Walhonding River, and Upper Muskingum River basins, some constituent concentrations associated with mining activities at some sites were high; however, $\mathrm{pH}$ was in the neutral to alkaline range at all sites. This combination of characteristics indicates buffering of streamwaters by carbonate strata or the effects of proper reclamation practices. The Conotton Creek, Upper Hocking River, and Middle Muskingum River basins each had one site where $\mathrm{pH}$ was in the acidic range. At these three sites, concentrations of dissolved sulfate and total recoverable and dissolved aluminum, iron, and manganese all were high. The water at the other sites in the Conotton Creek, Upper Hocking River, and Middle Muskingum River basins had $\mathrm{pH}$ in the alkaline range and lower concentrations of constituents associated with mining activities.

During the 1989-91 synoptic sampling, the streamwater quality at sites sampled in the Middle Hocking River basin and Leading Creek basin indicated possible effects from 
mining activities. In the Middle Hocking

River basin, four out of eight sites sampled had acidic waters with very high concentrations of dissolved sulfate and total recoverable and dissolved aluminum, iron, and manganese. In the Leading Creek basin, water from only one site was acidic, but waters from three out of the four sites sampled had high concentrations of some constituents associated with acid mine drainage.

In each of seven of the nine basins selected for synoptic sampling during 1989-91, four ground-water sites representative of water quality in shallow, productive aquifers were sampled. Most ground waters sampled were calcium bicarbonate-type waters, although some waters were fairly heterogeneous in ionic character. Most waters were classified as hard to very hard. Ohio Environmental Protection Agency water-quality standards for public supplies for dissolved solids $(500 \mathrm{mg} / \mathrm{L}$ ), iron $(300 \mu \mathrm{g} / \mathrm{L})$, manganese $(50 \mu \mathrm{g} / \mathrm{L})$, and sulfate $(250 \mathrm{mg} / \mathrm{L})$ were exceeded in waters from some wells. Except for high concentrations of total recoverable and dissolved iron at a few sites, the high concentrations of constituents associated with acid mine drainage and low $\mathrm{pH}$ were not found in the ground-water samples collected in the seven basins.

More than $\mathbf{5 0 0}$ samples were collected from the long-term streamwater network during 1985-91 to provide a general assessment of streamwater quality throughout the 21-basin study area. Throughout the 7-year period, the medians of water-quality properties and constituents did not change substantially. Several sites within the Moxahala Creek and Middle Hocking River basins (basins $\mathrm{O}$ and $\mathrm{Q}$, respectively) had acidic waters with high concentrations of aluminum, iron, manganese, and sulfate. Buffering of streamwaters in several basins was indicated by samples with $\mathrm{pH}$ values in the neutral to alkaline range and high concentrations of one or more of constituents associated with acid mine drainage.

The variability in water quality of different streams in the same drainage basin indicates the importance of proper site selection for identifying problem areas in the coal-mining region. Within individual basins, however, extreme concentrations of certain constituents can be used to identify sources of degradation that might be masked by buffering or downstream dilution.

Of the 21 study basins, 16 were sampled for ground water during 1985-91. Of the 69 wells sampled, 54 yielded from unconsolidated aquifers. In the ground-water samples analyzed, medians of most constituents were fairly consistent over time, except concentrations of total recoverable and dissolved iron. Most $\mathrm{pH}$ measurements were in the neutral to alkaline range, and, at a few sites, concentrations of dissolved sulfate or total recoverable and dissolved iron and manganese were high. In general, however, low pH and high concentrations of constituents associated with mining activities were not found in the ground-water samples collected during 1985-91. 
REFERENCES CITED

American Public Health Association, 1985, Standard methods for the examination of water and wastewater (16th ed.): Washington, D.C., American Public Health Association, 1,268 p.

Brant, R.A., and Delong, R.M., 1960, Coal resources of Ohio: Ohio Geological Survey Bulletin 58, $245 \mathrm{p}$.

Camp, T.R., 1963, Water and its impurities: New York, Reinhold, 355 p.

Carlton, R.W., 1991, The U.S. Geological Survey's National Coal Resources Data System, in Ohio- teamwork for the future of Ohio's coal, in Lopez, S.W., comp., 1989 Report on Ohio mineral industries with directories of reporting coal and industrial mineral operators: Ohio Geological Survey, p. 4-6.

Cashell, D.H., comp., 1988-91, Monthly water inventory report for Ohio: Ohio Department of Natural Resources, Division of Water, December issues (including annual summaries of precipitation).

Collins, H.R., 1979, The Mississippian and Pennsylvanian (Carboniferous) systems in the United States-Ohio: U.S. Geological Survey Professional Paper 1110-E, p. E1-E26.

Cross, W.P., 1967, Drainage area of Ohio streams - supplement to Gazetteer of Ohio streams: Ohio Department of Natural Resources, Division of Water, Ohio Water Plan Inventory Report 12A, $61 \mathrm{p}$.

Crowell, Katie, 1978, Ground-water resources of Columbiana County: Ohio Department of Natural Resources, Division of Water, map sheet, scale 1:62,500.

-1979, Ground-water resources of Holmes County: Ohio Department of Natural Resources, Division of Water, map sheet, scale 1:62,500.
1980, Ground-water resources of Harrison County, Ohio Department of Natural Resources, Division of Water, map sheet, scale 1:62,500.

Dyer, K.E., and Curtis, W.R., 1977, Effect of strip mining on water quality in small streams in eastern Kentucky, 1967-1975: U.S. Forest Service Research Paper NE-372, 13 p.

Eberle, Michael, and Razem, A.C., 1985, Effects of surface coal mining and reclamation on ground water in small watersheds in the Allegheny Plateau, Ohio: U.S. Geological Survey Water-Resources Investigations Report 85-4205, 13 p.

Federal Water Pollution Control

Administration, 1968, Stream pollution by coal mine drainage, upper Ohio River basin: U.S. Department of Interior, Federal Water Pollution Control Administration, Ohio Basin Region, Work Document 21, $116 \mathrm{p}$.

Fenneman, N.M., 1938, Physiography of eastern United States: New York, McGrawHill, $714 \mathrm{p}$.

Fishman, M.J., and Friedman, L.C., eds., 1989, Methods for determination of inorganic substances in water and fluvial sediments: U.S. Geological Survey Techniques of Water-Resources Investigations, book 5, chap. A1, 545 p.

Goldthwait, R.P., White, G.W., and Forsyth, J.L., 1961, Glacial map of Ohio, revised in part 1967: U.S. Geological Survey Miscellaneous Geological Investigations Map I-316, scale 1:500,000.

Harstine, L.J., 1991, Hydrologic atlas for Ohio: Ohio Department of Natural Resources, Division of Water, Inventory Report 28, 13 p., 4 map sheets.

Hartzell, G.W., 1982, Ground-water resources of Licking County: Ohio Department of Natural Resources, Division of Water, map sheet, scale 1:62,500. 
Hem, J.D., 1989, Study and interpretation of the chemical characteristics of natural water: U.S. Geological Survey WaterSupply Paper 2254, 263 p.

Hren, Janet, Wilson, K.S., and Helsel, D.R., 1984, A statistical approach to evaluate the relation of coal mining, land reclamation, and surface-water quality in Ohio: U.S. Geological Survey Water-Resources Investigations Report 84-4117, 325 p.

Jones, A.L., 1988, Geologic setting and water quality of selected basins in the active coal-mining areas of Ohio, June 1985 through December 1986: U.S. Geological Survey Water-Resources Investigations Report 88-4084, 85 p.

Krolczyk, J.C., 1954, Gazetteer of Ohio streams: Ohio Department of Natural Resources, Division of Water, Ohio Water Plan Inventory Report 12, $179 \mathrm{p}$.

Lamborn, R.E., 1951, Limestones of eastern Ohio: Ohio Geological Survey Bulletin 49, $377 \mathrm{p}$.

Lopez, S.W., comp., 1991, 1989 report on Ohio mineral industries with directories of reporting coal and industrial mineral operators: Ohio Geological Survey, 136 p.

Norris, S.E., and Mayer, G.C., 1982, Water resources of the Black Hand Sandstone member of the Cuyahoga Formation and associated aquifers of Mississippian age in southeastern Ohio: U.S. Geological Survey Open-File Report 82-170, 72 p.

Ohio Board on Unreclaimed Strip Mined Lands, 1974, Land reborn: $91 \mathrm{p}$.

Ohio Department of Natural Resources, Ohio Capability Analysis Program, 1987, Land use, southeast Ohio: map sheet, scale 1:50,000.

Ohio Environmental Protection Agency, 1989, Rules and regulations, public water systems, primary contaminant control, water quality standards: Chapter 3745.81 of the Ohio Administrative Code.
Pfaff, C.L., Helsel, D.R., Johnson, D.P., and Angelo, C.G., 1981, Assessment of water quality in streams draining coal-producing areas in Ohio: U.S. Geological Survey Water-Resources Investigations Open-File Report 81-409, 98 p.

Pree, H.L., 1962a, A part of the Walhonding River basin, underground water resources: Ohio Department of Natural Resources, Division of Water, map sheet, scale 1:125,000.

1962b, Lower Raccoon Creek basin, underground water resources: Ohio Department of Natural Resources, Division of Water, map sheet, scale 1:125,000.

Rantz, S.E., and others, 1982, Measurement and computation of streamflowvolume 1, measurement of stage and discharge: U.S. Geological Survey WaterSupply Paper 2175, $284 \mathrm{p}$.

Razem, A.C., and Sedam, A.C., 1985, Groundwater quality and geochemistry of aquifers associated with coal in the Allegheny and Monongahela Formations, southeastern Ohio: U.S. Geological Survey WaterResources Investigations Report 85-4034, $39 \mathrm{p}$.

Schmidt, J.J., 1959, Yellow Creek, Cross Creek and McIntyre Creek basins, underground water resources: Ohio Department of Natural Resources, Division of Water, map sheet, scale 1:125,000. 1962a, Conotton Creek basin, underground water resources: Ohio Department of Natural Resources, Division of Water, map sheet, scale 1:125,000.

$1962 b$, Part of the upper portion of the Muskingum River basin, underground water resources: Ohio Department of Natural Resources, Division of Water, map sheet, scale $1: 125,000$.

1980, Ground-water resources of Knox County: Ohio Department of Natural Resources, Division of Water, map sheet, scale 1:62,000. 
1985 , Ground-water resources of Athens and Meigs Counties: Ohio Department of Natural Resources, Division of Water, map sheet, scale 1:135,000.

Sedam, A.C., 1991, Geologic setting and water quality of selected basins in the active coal-mining areas of Ohio, 1987-88: U.S. Geological Survey Water-Resources Investigations Report 90-4109, $97 \mathrm{p}$.

Sedam, A.C., Giessner, F.W., and Eberle, Michael, 1985, Ohio ground-water resources, in National Water Summary 1984: U.S. Geological Survey WaterSupply Paper 2275, p. 341-346.

Stout, Wilber, 1927, Geology of Vinton County, Ohio: Ohio Geological Survey Bulletin 31, $402 \mathrm{p}$.

Stout, Wilber, Ver Steeg, Karl, and Lamb, G.F., 1943, Geology of water in Ohio: Ohio Geological Survey Bulletin 44, 694 p.

Sturgeon, Myron T., and Associates, 1958, The geology and mineral resources of Athens County, Ohio: Ohio Geological Survey Bulletin 57, 600 p.

Sugar, D.J., 1988, Ground-water resources of Coshocton County: Ohio Department of Natural Resources, Division of Water, map sheet, scale 1:62,500.

Thurman, E.M., 1985, Organic geochemistry of natural waters: Dordrecht, The Netherlands, Martinus Nijhoff/Dr. W. Junk, Publishers, 497 p.

U.S. Department of the Interior, 1979, Permanent regulatory program implementing Section 501(b) of the Surface Mining Control and Reclamation Act of 1977: U.S. Department of the Interior, Office of Surface Mining Reclamation and Enforcement, Final Environmental Statement OSM-EIS-1 [variously paged].

U.S. Environmental Protection Agency, 1986, Quality criteria for water, 1986: Office of Water, EPA 440/5-86-001 [variously paged].
U.S. Geological Survey, Office of Water Data Coordination, 1977, Sediment, in National handbook of recommended methods for water data acquisition: Chap. 3, 100 p.

Walker, A.C., 1958a, Hocking River basin (middle portion), underground water resources: Ohio Department of Natural Resources, Division of Water, map sheet, scale 1:125,000. 1958b, Shade River and Leading Creek basins, underground water resources: Ohio Department of Natural Resources, Division of Water, map sheet, scale 1:125,000. 1962a, A portion of the middle of Muskingum River basin, underground water resources: Ohio Department of Natural Resources, Division of Water, map sheet, scale 1:125,000.

1962b, Lower Wills Creek basin, underground water resources: Ohio Department of Natural Resources, Division of Water, map sheet, scale 1:125,000. -1984 , Ground-water resources of Washington and Morgan Counties: Ohio Department of Natural Resources, Division of Water, map sheet, scale 1:185,000. Wangsness, D.J., 1982, Reconnaissance of stream biota and physical and chemical water quality in areas of selected land use in the coal-mining region, southwestern Indiana, 1979-80: U.S. Geological Survey Open-File Report 82-566, 43 p.

Ward, P.E., and Wilmoth, B.M., 1968, Groundwater hydrology of the Monongahela River basin in West Virginia: West Virginia Geological and Economic Survey, River Basin Bulletin 1, $54 \mathrm{p}$.

Wilson, K.S., 1985, Surface-water quality of coal-mine lands in Raccoon Creek basin, Ohio: U.S. Geological Survey WaterResources Investigations Report 85-4060, $61 \mathrm{p}$. 
1988, Chemical quality, benthic organisms, and sedimentation in streams draining coal-mined lands in Raccoon Creek basin, Ohio, July 1984 through September 1986: U.S. Geological Survey Water-Resources Investigations

Report 88-4022, 80 p. 
Table 31. Water-quality data for long-term streamwater sites, 1989-91

$\left[{ }^{\circ} \mathrm{C}\right.$, degrees Celsius; $\mathrm{ft}^{3} / \mathrm{s}$, cubic feet per second; $\mathrm{mg} / \mathrm{L}$, milligrams per liter; $\mu \mathrm{g} / \mathrm{L}$, micrograms per liter; $\mu \mathrm{S} / \mathrm{cm}$, microsiemens per centimeter at 25 degrees Celsius; --, data not available]

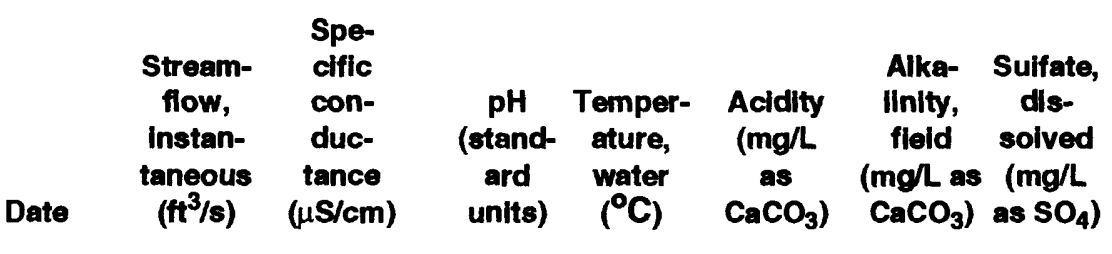

03109500 A-1 L BEAVER C NR EAST LIVERPOOL OH (LAT 4040 33N LONG 08032 27W)

\begin{tabular}{|c|c|c|c|c|c|c|c|}
\hline AUG 1989 & & & & & & & \\
\hline $15 .$. & 82 & 928 & 8.3 & 21.5 & -- & 124 & 270 \\
\hline OCT & & & & & & & \\
\hline $\begin{array}{c}17 \ldots \\
\text { SEPT } 1990\end{array}$ & 67 & 900 & 8.2 & 16.5 & -- & 155 & \\
\hline $\begin{array}{c}04 . . . \\
\text { JUNE } 1991\end{array}$ & 135 & 740 & 9.1 & 23.0 & -- & 146 & \\
\hline $\begin{array}{l}07 . . \\
\text { AUG }\end{array}$ & 106 & 720 & 8.9 & 23.0 & -- & 133 & \\
\hline $\mathrm{OCT}^{27 \ldots}$ & 40 & 840 & 8.3 & 23.5 & -- & 114 & \\
\hline $30 \ldots$ & 59 & 832 & 8.4 & 10.0 & - & 155 & \\
\hline
\end{tabular}

03109100 A-2 M F L BEAVER C NR ROGERS OH (LAT 4043 22N LONG 08038 03W)

$\begin{array}{llllllll}\begin{array}{c}\text { AUG } 1989 \\ 15 \ldots\end{array} & 29 & 874 & 8.2 & 19.5 & -- & 149 & 200 \\ \begin{array}{c}\text { OCT } \\ 17 \ldots\end{array} & 29 & 890 & 8.1 & 16.0 & -- & 149 & 180 \\ \begin{array}{c}\text { JULY } 1990 \\ 10 \ldots\end{array} & 47 & 630 & 8.1 & 23.5 & -- & 109 & 140 \\ \begin{array}{c}\text { JUNE } 1991 \\ \quad 07 \ldots\end{array} & 35 & 735 & 8.4 & 18.5 & -- & 150 & 170 \\ \begin{array}{c}\text { AUG } \\ 27 \ldots\end{array} & 14 & 860 & 8.3 & 22.0 & -- & 145 & 170 \\ \begin{array}{c}\text { OCT } \\ 30 \ldots\end{array} & 22 & 1020 & 8.4 & 9.0 & -- & 183 & 180\end{array}$

03110000 B-1 YELLOW C NR HAMMONDSVILLE OH (LAT 4032 16N LONG $0804331 \mathrm{~W}$ )

$\begin{array}{llllllll}\begin{array}{c}\text { AUG } 1989 \\ 15 \ldots\end{array} & 17 & 640 & 8.3 & 23.0 & -- & 88 & 200 \\ \begin{array}{c}\text { OCT } \\ 17 \ldots\end{array} & 18 & 580 & 8.1 & 16.5 & - & 100 & 180 \\ \begin{array}{c}\text { JULY } 1990 \\ 10 \ldots\end{array} & 25 & 585 & 8.5 & 27.0 & -- & 93 & 170 \\ \begin{array}{c}\text { JUNE } 1991 \\ \text { 07... }\end{array} & 22 & 540 & 8.4 & 20.5 & - & 93 & 180 \\ \begin{array}{c}\text { AUG } \\ 27 \ldots\end{array} & 5.5 & 650 & 7.9 & 23.5 & -- & 82 & 200 \\ \begin{array}{c}\text { OCT } \\ 30 . . .\end{array} & 35 & 598 & 8.1 & 9.0 & -- & 123 & 190\end{array}$


Table 31. Water-quality data for long-term streamwater sites, 1989-91--Continued

\begin{tabular}{|c|c|c|c|c|c|c|}
\hline Date & $\begin{array}{l}\text { Aluml- } \\
\text { num, } \\
\text { total } \\
\text { recov- } \\
\text { erable } \\
\text { ( } \mu \mathrm{g} / \\
\text { as } \mathrm{Al} \text { ) }\end{array}$ & $\begin{array}{l}\text { Aluml- } \\
\text { num, } \\
\text { dis- } \\
\text { solved } \\
\text { ( } \mu \mathrm{g} / \\
\text { as Al) }\end{array}$ & $\begin{array}{l}\text { Iron, } \\
\text { total } \\
\text { recov- } \\
\text { erable } \\
\text { ( } \mu g / \mathrm{L} \\
\text { as Fe) }\end{array}$ & $\begin{array}{l}\text { Iron, } \\
\text { dis- } \\
\text { solved } \\
(\mu g / L \\
\text { as Fe) }\end{array}$ & $\begin{array}{c}\text { Manga- } \\
\text { nese, } \\
\text { total } \\
\text { recov- } \\
\text { erable } \\
\text { ( } \mu \mathrm{g} / \mathrm{L} \\
\text { as } \mathrm{Mn} \text { ) }\end{array}$ & $\begin{array}{l}\text { Manga- } \\
\text { nese, } \\
\text { dis- } \\
\text { solved } \\
(\mu g / L \\
\text { as Mn) }\end{array}$ \\
\hline
\end{tabular}

03109500 A-1 L BEAVER C NR EAST LIVERPOOL OH (LAT 4040 33N LONG 08032 27W)

$\begin{array}{lcccccc}\begin{array}{c}\text { AUG } 1989 \\ 15 \ldots\end{array} & 90 & 40 & 150 & 20 & 50 & 20 \\ \begin{array}{c}\text { OCT } \\ 17 \ldots\end{array} & 30 & <10 & 120 & 10 & 40 & 20 \\ \begin{array}{c}\text { SEPT } 1990 \\ \quad 04 \ldots\end{array} & 260 & 10 & 190 & 10 & 20 & 20 \\ \begin{array}{c}\text { JUNE } 1991 \\ \quad 07 \ldots\end{array} & 110 & 20 & 240 & 10 & 50 & 20 \\ \begin{array}{c}\text { AUG } \\ 27 \ldots\end{array} & 270 & 100 & 610 & 130 & 90 & 50 \\ \begin{array}{c}\text { OCT } \\ 30 \ldots\end{array} & 20 & 10 & 60 & <10 & 30 & 20\end{array}$

03109100 A-2 M F L BEAVER C NR ROGERS OH (LAT 4043 22N LONG 08038 03W)

$\begin{array}{lcccccc}\begin{array}{c}\text { AUG 1989 } \\ 15 \ldots\end{array} & 140 & 40 & 290 & 10 & 90 & 40 \\ \begin{array}{c}\text { OCT } \\ 17 \ldots\end{array} & 80 & <10 & 300 & 10 & 90 & 60 \\ \begin{array}{c}\text { JULY } 1990 \\ 10 \ldots\end{array} & 1100 & 20 & 2700 & 20 & 300 & 70 \\ \begin{array}{c}\text { JUNE } 1991 \\ \text { 07... }\end{array} & 160 & 30 & 430 & 160 & 110 & 70 \\ \begin{array}{c}\text { AUG } \\ 27 \ldots\end{array} & 260 & 30 & 610 & 20 & 110 & 50 \\ \begin{array}{c}\text { OCT } \\ 30 \ldots\end{array} & 90 & 10 & 230 & 20 & 70 & 40\end{array}$

03110000 B-1 YELLOW C NR HAMMONDSVILLE OH (LAT 4032 16N LONG 08043 31W)

\begin{tabular}{|c|c|c|c|c|c|c|}
\hline \multicolumn{7}{|l|}{ AUG 1989} \\
\hline $15 \ldots$ & 170 & 80 & 300 & $<10$ & 30 & 20 \\
\hline OCT & & & & & & \\
\hline $\begin{array}{c}17 \ldots \\
\text { JULY } 1990\end{array}$ & 40 & 20 & 240 & 20 & 30 & $<10$ \\
\hline $\begin{array}{c}10 \ldots \\
\text { JUNE } 1991\end{array}$ & 120 & 60 & 160 & $<10$ & 30 & 20 \\
\hline $\begin{array}{l}07 . . . \\
\text { AUG }\end{array}$ & 220 & 40 & 660 & 20 & 40 & 10 \\
\hline $\mathrm{OCT}^{27 . .}$ & 140 & 20 & 510 & 20 & 60 & 30 \\
\hline $30 .$. & 50 & 20 & 100 & $<10$ & 60 & 20 \\
\hline
\end{tabular}


Table 31. Water-quality data for long-term streamwater sites, 1989-91--Continued

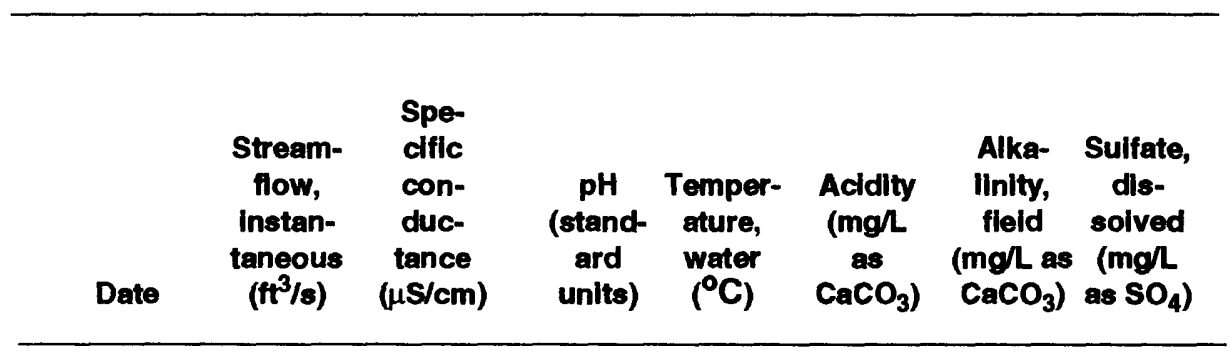

401857080391700 B-2 CROSS C NR MINGO JUNCTION OH (LAT 4018 57N LONG 08039 17W)

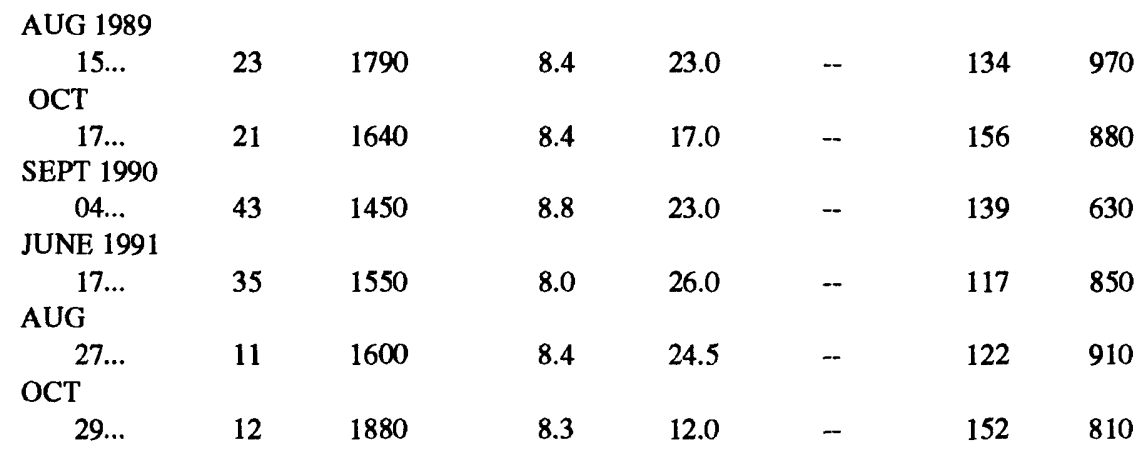

401716080451300 B-3 MCINTYRE C NR SMITHFIELD OH (LAT 40 17 16N LONG 08045 13W)

\begin{tabular}{|c|c|c|c|c|c|c|c|}
\hline \multicolumn{8}{|l|}{ AUG 1989} \\
\hline OCT $^{16 \ldots}$ & 8.6 & 2270 & 8.1 & 21.0 & -- & 135 & 1300 \\
\hline $\begin{array}{c}18 \ldots \\
\text { SEPT } 1990\end{array}$ & 7.4 & 2010 & 8.2 & 12.5 & -- & 214 & 1200 \\
\hline $\begin{array}{c}05 . . \\
\text { JUNE } 1991\end{array}$ & 12 & 2100 & 8.2 & 20.0 & -- & 214 & 1200 \\
\hline AUG $^{17 . . .}$ & 7.9 & 2100 & 7.9 & 26.5 & -- & 204 & 1200 \\
\hline OCT $^{28 \ldots . .}$ & 2.6 & 1600 & 8.2 & 23.0 & - & 187 & 1100 \\
\hline $29 . .$. & 6.4 & 2300 & 8.2 & 12.0 & -- & 192 & 1200 \\
\hline
\end{tabular}

03111548 C-1 WHEELING C BL BLAINE OH (LAT 400401 N LONG 08048 31W)

AUG 1989

\begin{tabular}{|c|c|c|c|c|c|c|c|}
\hline $\mathrm{OCT}^{14 \ldots}$ & 36 & 2420 & 8.1 & 24.5 & - & 196 & 1300 \\
\hline $\begin{array}{c}16 \ldots \\
\text { SEPT } 1990\end{array}$ & 27 & 2350 & 8.4 & 18.0 & - & 215 & 1300 \\
\hline $\begin{array}{c}\text { 05... } \\
\text { JUNE } 1991\end{array}$ & 46 & 2100 & 8.2 & 20.0 & -. & 220 & 1000 \\
\hline AUG $^{18 . .}$ & 48 & 2080 & 7.8 & 20.5 & - & 196 & 1100 \\
\hline OCT $^{28 \ldots}$ & 20 & 2600 & 7.8 & 22.0 & - & 176 & 610 \\
\hline $29 \ldots$ & 17 & 2730 & 7.9 & 10.0 & -- & 207 & 1300 \\
\hline
\end{tabular}


Table 31. Water-quality data for long-term streamwater sites, 1989-91--Continued

\begin{tabular}{|c|c|c|c|c|c|c|}
\hline Date & $\begin{array}{c}\text { Aluml- } \\
\text { num, } \\
\text { totai } \\
\text { recov- } \\
\text { erable } \\
(\mu g / 2 \\
\text { as Ai) }\end{array}$ & $\begin{array}{l}\text { Aluml- } \\
\text { num, } \\
\text { dis- } \\
\text { solved } \\
\text { ( } \mu g / \\
\text { as Ai) }\end{array}$ & $\begin{array}{l}\text { Iron, } \\
\text { totai } \\
\text { recov- } \\
\text { erable } \\
\text { ( } \mu g / L \\
\text { as Fe) }\end{array}$ & $\begin{array}{l}\text { iron, } \\
\text { dis- } \\
\text { solved } \\
\text { ( } \mu \text { g/l } \\
\text { as Fe) }\end{array}$ & $\begin{array}{c}\text { Manga- } \\
\text { nese, } \\
\text { totai } \\
\text { recov- } \\
\text { erable } \\
(\mu g / \text {. } \\
\text { as } M n)\end{array}$ & $\begin{array}{l}\text { Manga- } \\
\text { nese, } \\
\text { dls- } \\
\text { solved } \\
\text { ( } \mu g / \mathbf{L} \\
\text { as Mn) }\end{array}$ \\
\hline
\end{tabular}

401857080391700 B-2 CROSS C NR MINGO JUNCTION OH (LAT 4018 57N LONG 0803917 W)

$\begin{array}{lcccccr}\begin{array}{c}\text { AUG } 1989 \\ 15 \ldots\end{array} & 340 & 140 & 240 & 10 & 140 & 110 \\ \begin{array}{c}\text { OCT } \\ 17 \ldots\end{array} & 150 & 50 & 180 & <10 & 100 & 70 \\ \begin{array}{c}\text { SEPT } 1990 \\ \text { 04... }\end{array} & 1300 & 80 & 500 & 20 & 210 & 20 \\ \begin{array}{c}\text { JUNE } 1991 \\ 17 \ldots\end{array} & 560 & 140 & 450 & 140 & 200 & 180 \\ \begin{array}{c}\text { AUG } \\ 27 \ldots\end{array} & 330 & 80 & 280 & <10 & 150 & 140 \\ \begin{array}{c}\text { OCT } \\ 29 \ldots\end{array} & 500 & <10 & 750 & <10 & 140 & 40\end{array}$

401716080451300 B-3 MCINTYRE C NR SMITHFIELD OH (LAT 4017 16N LONG 08045 13W)

AUG 1989

\begin{tabular}{|c|c|c|c|c|c|c|}
\hline $16 \ldots$ & 220 & 150 & 220 & 20 & 120 & 80 \\
\hline \multicolumn{7}{|l|}{ OCT } \\
\hline $18 \ldots$ & 40 & 50 & 120 & 20 & 70 & 60 \\
\hline SEPT 1990 & & & & & & \\
\hline $05 \ldots$ & 290 & 90 & 230 & 60 & 110 & 80 \\
\hline JUNE 1991 & & & & & & \\
\hline $17 \ldots$ & 120 & 60 & 170 & 100 & 40 & 30 \\
\hline AUG & & & & & & \\
\hline $28 \ldots$ & 50 & 50 & 260 & 20 & 40 & 50 \\
\hline OCT & & & & & & \\
\hline $29 .$. & 50 & 50 & 60 & 10 & 50 & 50 \\
\hline
\end{tabular}

03111548 C-1 WHEELING C BL BLAINE OH (LAT 4004 01N LONG 08048 31W)

$\begin{array}{lcccccc}\begin{array}{c}\text { AUG } 1989 \\ 14 \ldots\end{array} & 880 & 400 & 1600 & 10 & 100 & 80 \\ \begin{array}{c}\text { OCT } \\ 16 \ldots\end{array} & 500 & 340 & 860 & 20 & 110 & 80 \\ \begin{array}{c}\text { SEPT } 1990 \\ \text { 05... }\end{array} & 610 & 270 & 300 & 230 & 80 & 80 \\ \begin{array}{c}\text { JUNE } 1991 \\ 18 \ldots\end{array} & 2000 & 140 & 6900 & 130 & 230 & 160 \\ \begin{array}{c}\text { AUG } \\ 28 \ldots\end{array} & 2100 & 190 & 9300 & <10 & 220 & 170 \\ \begin{array}{c}\text { OCT } \\ 29 . . .\end{array} & 80 & 60 & 3900 & <10 & 170 & 130\end{array}$


Table 31. Water-quality data for long-term streamwater sites, 1989-91--Continued

\begin{tabular}{|c|c|c|c|c|c|c|c|}
\hline Date & $\begin{array}{c}\text { Stream- } \\
\text { flow, } \\
\text { instan- } \\
\text { taneous } \\
\left(\mathrm{ft}^{3} / \mathrm{s}\right)\end{array}$ & $\begin{array}{l}\text { Spe- } \\
\text { cific } \\
\text { con- } \\
\text { duc- } \\
\text { tance } \\
(\mu S / \mathrm{cm})\end{array}$ & $\begin{array}{l}\text { pH } \\
\text { (stand- } \\
\text { ard } \\
\text { units) }\end{array}$ & $\begin{array}{c}\text { Temper- } \\
\text { ature, } \\
\text { water } \\
\left({ }^{\circ} \mathrm{C}\right)\end{array}$ & $\begin{array}{c}\text { Acidity } \\
\text { (mg/L } \\
\text { as } \\
\left.\mathrm{CaCO}_{3}\right)\end{array}$ & $\begin{array}{c}\text { Alka- } \\
\text { linity, } \\
\text { field } \\
\text { (mg/L as } \\
\mathrm{CaCO}_{3} \text { ) }\end{array}$ & $\begin{array}{c}\text { Sulfate, } \\
\text { dls- } \\
\text { solved } \\
\text { (mg/L } \\
\left.\text { as } \mathrm{SO}_{4}\right)\end{array}$ \\
\hline 03111500 & C-2 SHORT & NR DILLC & VALE OH & H (LAT 40 & $136 \mathrm{~N} \mathrm{LON}$ & G 080440 & $4 W$ ) \\
\hline $\begin{array}{c}\text { AUG } 1989 \\
16 \ldots \\
\text { OCT }\end{array}$ & 48 & 2310 & 8.0 & 19.5 & - & 121 & 1300 \\
\hline $\begin{array}{c}18 \ldots \\
\text { SEPT } 1990\end{array}$ & 42 & 2050 & 8.1 & 11.5 & -- & 194 & 1100 \\
\hline $\begin{array}{c}05 \ldots \\
\text { JUNE } 1991\end{array}$ & 72 & 2050 & 8.2 & 19.5 & -- & 200 & 920 \\
\hline AUG $^{17 \ldots}$ & 52 & 2120 & 8.0 & 26.0 & -- & 166 & 1200 \\
\hline OCT $^{28 \ldots}$ & 18 & 2100 & 8.0 & 22.0 & - & 179 & 1200 \\
\hline $29 \ldots$ & 17 & 2280 & 8.0 & 11.0 & -- & 212 & 1200 \\
\hline
\end{tabular}

03114000 D-1 CAPTINA C AT ARMSTRONGS MILLS OH (LAT 3954 3IN LONG 08055 27W)

AUG 1989

\begin{tabular}{|c|c|c|c|c|c|c|c|}
\hline \multicolumn{8}{|l|}{ AUG 1989} \\
\hline $14 \ldots$ & 8.6 & 659 & 8.2 & 22.5 & - & 147 & 160 \\
\hline OCT & & & & & & & \\
\hline $\begin{array}{c}16 \ldots \\
\text { SEPT } 1990\end{array}$ & 38 & 515 & 8.5 & 17.0 & -- & 158 & 100 \\
\hline $\begin{array}{c}05 \ldots \\
\text { JUNE } 1991\end{array}$ & 46 & 450 & 8.3 & 24.0 & -- & 141 & 63 \\
\hline $18 \ldots$ & 29 & 430 & 8.2 & 25.0 & -- & 124 & 73 \\
\hline AUG & & & & & & & \\
\hline $\begin{array}{l}26 \ldots \\
\text { OCT }\end{array}$ & 2.2 & 710 & 8.5 & 29.5 & -- & 133 & 170 \\
\hline $28 \ldots$ & 4.7 & 1100 & 8.3 & 17.5 & -- & 183 & 240 \\
\hline
\end{tabular}

03113550 D-2 MCMAHON C AT BELLAIRE OH (LAT 4000 39N LONG 08045 45W)

$\begin{array}{cccccccc}\begin{array}{c}\text { AUG } 1989 \\ 14 \ldots\end{array} & 17 & 1020 & 8.2 & 25.0 & - & 144 & 370 \\ \begin{array}{c}\text { OCT } \\ 16 \ldots\end{array} & 26 & 910 & 8.4 & 17.5 & - & 165 & 300 \\ \begin{array}{c}\text { SEPT } 1990 \\ \quad 05 \ldots\end{array} & 20 & 1020 & 8.1 & 21.5 & - & 168 & 340 \\ \begin{array}{c}\text { JUNE } 1991 \\ \quad 18 \ldots\end{array} & 39 & 795 & 7.9 & 23.0 & - & 126 & 250 \\ \begin{array}{c}\text { AUG } \\ 26 \ldots\end{array} & 4.6 & 1200 & 8.1 & 26.5 & -- & 134 & 480 \\ \begin{array}{c}\text { OCT } \\ 29 \ldots\end{array} & 5.2 & 1430 & 8.0 & 11.5 & -- & 174 & 570\end{array}$


Table 31. Water-quality data for long-term streamwater sites, 1989-91--Continued

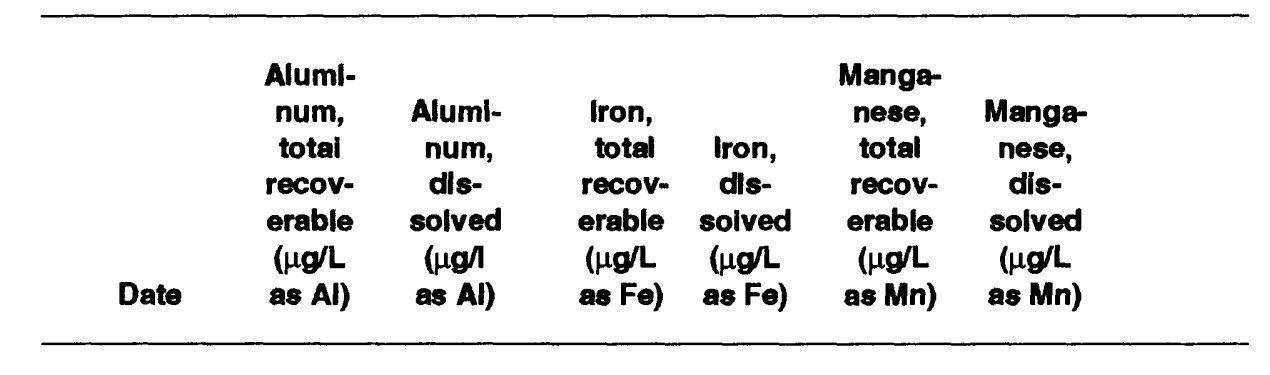

03111500 C-2 SHORT C NR DILLONVALE OH (LAT 4011 36N LONG 08044 04W)

$\begin{array}{ccccccc}\begin{array}{c}\text { AUG } 1989 \\ 16 \ldots\end{array} & 530 & 230 & 1300 & 10 & 80 & 50 \\ \begin{array}{c}\text { OCT } \\ 18 \ldots\end{array} & 330 & 100 & 620 & 20 & 40 & 30 \\ \begin{array}{c}\text { SEPT } 1990 \\ \text { 05... }\end{array} & 410 & 230 & 1000 & 210 & 50 & 50 \\ \begin{array}{c}\text { JUNE } 1991 \\ 17 \ldots\end{array} & 540 & 230 & 1400 & 140 & 60 & 50 \\ \begin{array}{c}\text { AUG } \\ 28 \ldots\end{array} & 230 & 170 & 620 & 130 & 40 & 30 \\ \begin{array}{c}\text { OCT } \\ 29 \ldots\end{array} & 180 & 90 & 290 & <10 & 30 & 30\end{array}$

03114000 D-1 CAPTINA C AT ARMSTRONGS MILLS OH (LAT 3954 31N LONG 08055 27W)

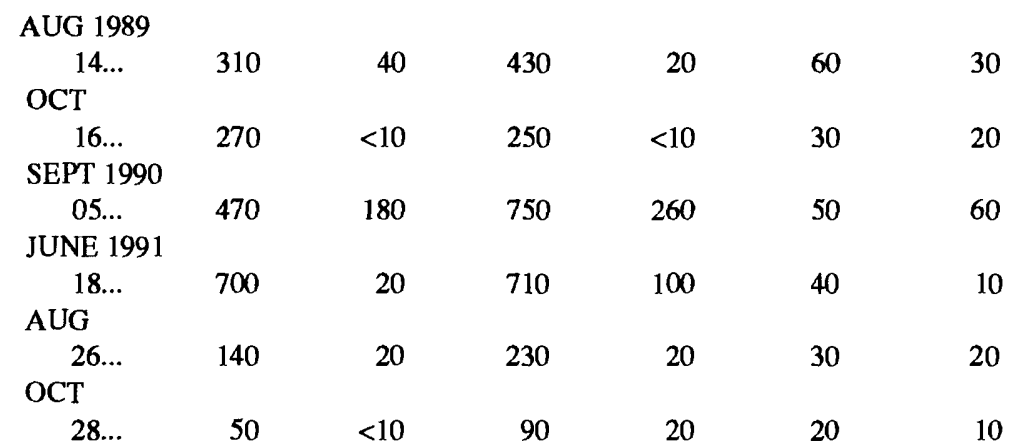

03113550 D-2 MCMAHON C AT BELLAIRE OH (LAT 400039 N LONG $0804545 \mathrm{~W}$ )

AUG 1989

$\begin{array}{ccccccc}\begin{array}{c}14 \ldots \\ \text { OCT }\end{array} & 350 & 300 & 350 & <10 & 30 & 30 \\ \begin{array}{l}16 \ldots \\ \text { SEPT } 1990 \\ \text { 05... }\end{array} & 1800 & 230 & 3100 & 20 & 120 & 40 \\ \begin{array}{c}\text { JUNE } 1991 \\ 18 \ldots\end{array} & 1800 & 100 & 3100 & 10 & 100 & 20 \\ \begin{array}{c}\text { AUG } \\ 26 \ldots\end{array} & 480 & 120 & 1000 & 250 & 70 & 50 \\ \begin{array}{c}\text { OCT } \\ 29 \ldots\end{array} & 80 & 20 & 340 & <10 & 40 & 30\end{array}$


Table 31. Water-quality data for long-term streamwater sites, 1989-91--Continued

\begin{tabular}{|c|c|c|c|c|c|c|c|}
\hline Date & $\begin{array}{l}\text { Stream- } \\
\text { flow, } \\
\text { Instan- } \\
\text { taneous } \\
\left(\mathrm{ft}^{3} / \mathrm{s}\right)\end{array}$ & $\begin{array}{c}\text { Spe- } \\
\text { cific } \\
\text { con- } \\
\text { duc- } \\
\text { tance } \\
(\mu S / c m)\end{array}$ & $\begin{array}{l}\text { pH } \\
\text { (stand- } \\
\text { ard } \\
\text { units) }\end{array}$ & $\begin{array}{l}\text { Temper- } \\
\text { ature, } \\
\text { water } \\
\left({ }^{\circ} \mathrm{C}\right)\end{array}$ & $\begin{array}{c}\text { Acidity } \\
\text { (mg/L } \\
\text { as } \\
\mathrm{CaCO}_{3} \text { ) }\end{array}$ & $\begin{array}{c}\text { Alka- } \\
\text { Ilnlty, } \\
\text { field } \\
\text { (mg/L as } \\
\mathrm{CaCO}_{3} \text { ) }\end{array}$ & $\begin{array}{l}\text { Sulfate, } \\
\text { dls- } \\
\text { soived } \\
\text { (mg/ } \\
\text { as } \mathrm{SO}_{4} \text { ) }\end{array}$ \\
\hline
\end{tabular}

03114250 D-3 SUNFISH C AT CAMERON OH (LAT $394600 \mathrm{~N}$ LONG $0805609 \mathrm{~W}$ )

$\begin{array}{llllllll}\begin{array}{c}\text { AUG } 1989 \\ 14 \ldots\end{array} & 3.1 & 415 & 8.3 & 27.0 & - & 131 & 42 \\ \begin{array}{c}\text { OCT } \\ 16 \ldots\end{array} & 37 & 350 & 8.6 & 16.0 & - & 165 & 40 \\ \begin{array}{c}\text { SEPT } 1990 \\ \text { 05... }\end{array} & 9.4 & 400 & 8.5 & 26.5 & -- & 129 & 34 \\ \begin{array}{c}\text { JUNE } 1991 \\ 18 \ldots\end{array} & 6.5 & 380 & 8.6 & 27.0 & -- & 128 & 44 \\ \begin{array}{c}\text { AUG } \\ 26 \ldots\end{array} & 1.1 & 410 & 8.2 & 27.5 & -- & 126 & 42 \\ \begin{array}{c}\text { OCT } \\ 28 \ldots\end{array} & .81 & 535 & 8.1 & 17.5 & -- & 174 & 59\end{array}$

03117500 E-1 SANDY C AT WAYNESBURG OH (LAT $404021 \mathrm{~N}$ LONG $0811536 \mathrm{~W}$ )

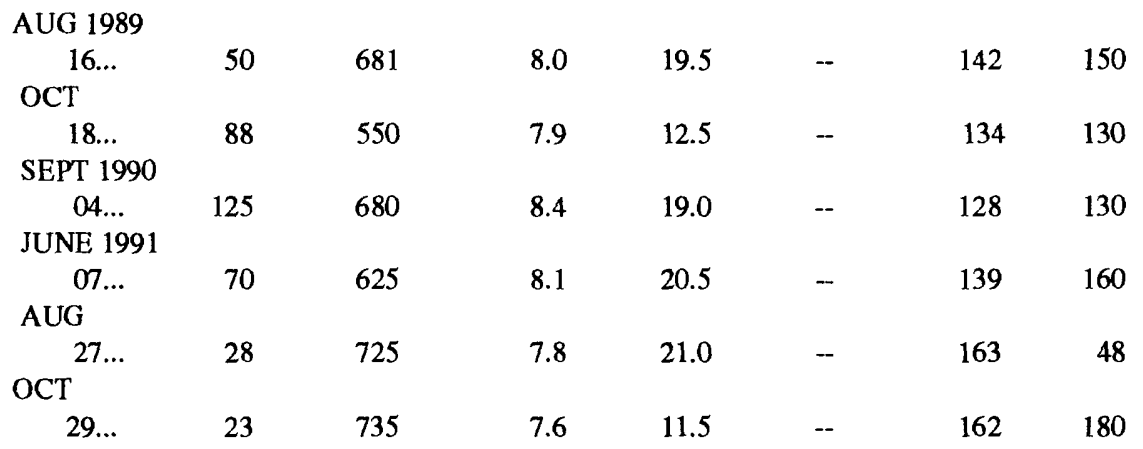

403823081213700 E-2 NIMISHILLEN CR AT SANDYVILLE OH (LAT 4038 23N LONG 0812137 W)

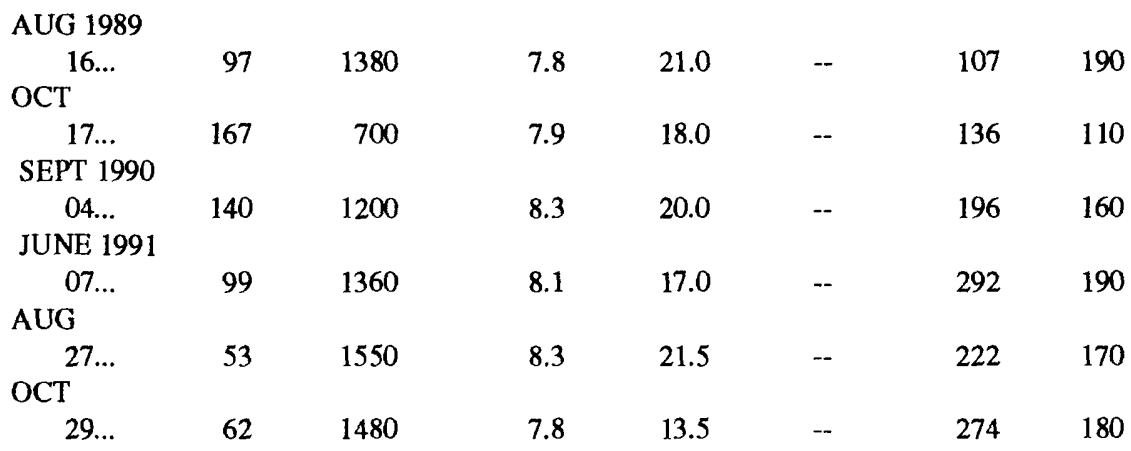


Table 31. Water-quality data for long-term streamwater sites, 1989-91--Continued

\begin{tabular}{|c|c|c|c|c|c|c|}
\hline Date & $\begin{array}{l}\text { Alumi- } \\
\text { num, } \\
\text { totai } \\
\text { recov- } \\
\text { erable } \\
\text { ( } \mu \mathrm{g} / \\
\text { as } \mathrm{Al} \text { ) }\end{array}$ & $\begin{array}{l}\text { Aiumi- } \\
\text { num, } \\
\text { dlis- } \\
\text { solved } \\
\text { ( } \mu \mathrm{g} / \\
\text { as Al) }\end{array}$ & $\begin{array}{l}\text { iron, } \\
\text { total } \\
\text { recov- } \\
\text { erabie } \\
\text { ( } \mu \mathrm{g} / \mathrm{L} \\
\text { as Fe) }\end{array}$ & $\begin{array}{l}\text { iron, } \\
\text { dis- } \\
\text { solved } \\
\text { ( } \mu \mathrm{g} / \mathrm{L} \\
\text { as Fe) }\end{array}$ & $\begin{array}{c}\text { Manga- } \\
\text { nese, } \\
\text { total } \\
\text { recov- } \\
\text { erable } \\
\text { ( } \mu \text { g/L } \\
\text { as Mn) }\end{array}$ & $\begin{array}{c}\text { Manga- } \\
\text { nese, } \\
\text { dis- } \\
\text { soived } \\
\text { ( } \mu g / \mathrm{L} \\
\text { as } \mathrm{Mn} \text { ) }\end{array}$ \\
\hline
\end{tabular}

03114250 D-3 SUNFISH C AT CAMERON OH (LAT 3946 OON LONG $0805609 \mathrm{~W}$ )

AUG 1989

\begin{tabular}{|c|c|c|c|c|c|c|}
\hline $14 \ldots$ & 150 & 40 & 170 & $<10$ & 30 & 20 \\
\hline OCT & & & & & & \\
\hline $\begin{array}{c}16 \ldots \\
\text { SEPT } 1990\end{array}$ & 10 & $<10$ & 110 & 10 & 10 & $<10$ \\
\hline $\begin{array}{c}05 \ldots \\
\text { JUNE } 1991\end{array}$ & 240 & 30 & 450 & 20 & 20 & 20 \\
\hline AUG $^{18 . . .}$ & 220 & 30 & 340 & 110 & 30 & 10 \\
\hline $\mathrm{OCT}^{26 \ldots}$ & 300 & 20 & 650 & 100 & 50 & 10 \\
\hline $28 \ldots$ & 30 & $<10$ & 20 & $<10$ & $<10$ & 20 \\
\hline
\end{tabular}

03117500 E-1 SANDY C AT WAYNESBURG OH (LAT $404021 \mathrm{~N}$ LONG $0811536 \mathrm{~W}$ )

$\begin{array}{ccccccc}\begin{array}{c}\text { AUG } 1989 \\ 16 \ldots\end{array} & 110 & 40 & 290 & 20 & 250 & 240 \\ \begin{array}{c}\text { OCT } \\ 18 \ldots\end{array} & 500 & 20 & 550 & 60 & 340 & 280 \\ \begin{array}{c}\text { SEPT } 1990 \\ \text { 04... }\end{array} & 120 & 30 & 700 & 70 & 270 & 260 \\ \begin{array}{c}\text { JUNE } 1991 \\ \text { 07... }\end{array} & 250 & 30 & 980 & 20 & 490 & 440 \\ \begin{array}{c}\text { AUG } \\ 27 \ldots\end{array} & 80 & <10 & 610 & <10 & 350 & 290 \\ \begin{array}{c}\text { OCT } \\ 29 \ldots\end{array} & 110 & 20 & 450 & 20 & 360 & 360\end{array}$

403823081213700 E-2 NIMISHILLEN CR AT SANDYVILLE OH (LAT 4038 23N LONG 08121 37W)

AUG 1989

\begin{tabular}{|c|c|c|c|c|c|}
\hline $\begin{array}{l}16 . . \\
\text { OCT }\end{array}$ & 140 & 50 & 460 & 40 & 90 \\
\hline $\begin{array}{c}17 \ldots \\
\text { SEPT } 1990\end{array}$ & 680 & 90 & 1200 & 290 & 220 \\
\hline $\begin{array}{c}04 \ldots \\
\text { JUNE } 1991\end{array}$ & 170 & 30 & 550 & 60 & 120 \\
\hline AUG & 230 & 20 & 790 & 40 & 140 \\
\hline OCT $^{27 \ldots}$ & 150 & 10 & 450 & 90 & 120 \\
\hline $29 \ldots$ & 80 & 10 & 200 & $<10$ & 60 \\
\hline
\end{tabular}


Table 31. Water-quality data for long-term streamwater sites, 1989-91--Continued

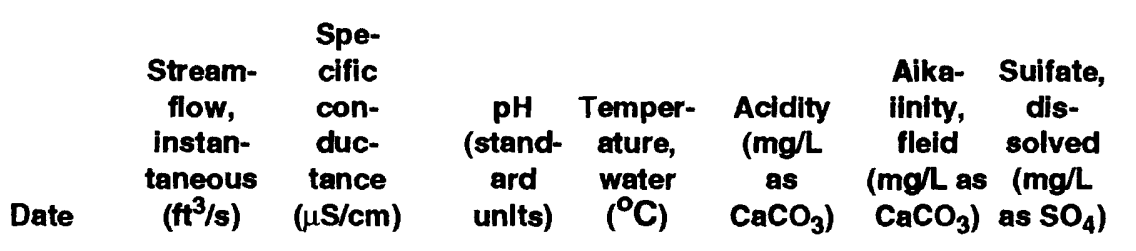

403426081211900 F-1 CONOTTON C NR SOMERDALE OH (LAT 4034 26N LONG 08121 19W)

$\begin{array}{llllllll}\begin{array}{c}\text { AUG } 1989 \\ 16 \ldots\end{array} & 40 & 510 & 7.5 & 20.0 & - & 81 & 130 \\ \begin{array}{c}\text { OCT } \\ 17 \ldots\end{array} & 36 & 495 & 7.6 & 16.0 & -- & 90 & 130 \\ \begin{array}{c}\text { JULY } 1990 \\ 11 \ldots\end{array} & 65 & 560 & 7.4 & 21.0 & -- & 74 & 160 \\ \begin{array}{c}\text { JUNE } 1991 \\ \quad 07 \ldots\end{array} & 52 & 440 & 7.5 & 16.5 & -- & 82 & 140 \\ \begin{array}{c}\text { AUG } \\ 27 \ldots\end{array} & 14 & 540 & 7.1 & 21.5 & -- & 95 & 27 \\ \text { OCT } \\ 29 . . .\end{array}$

03123000 G-1 SUGAR C AB BEACH CITY DAM AT BEACH CITY OH (LAT 4039 24N LONG 08134 37W)

AUG 1989

$\begin{array}{cccccccc}\begin{array}{c}16 \ldots \\ \text { OCT }\end{array} & 20 & 680 & 7.9 & 23.0 & - & 197 & 61 \\ \begin{array}{c}17 \ldots \\ \text { JULY } 1990\end{array} & 18 & 645 & 7.8 & 16.5 & -- & 217 & 71 \\ \begin{array}{l}10 \ldots \\ \text { JUNE } 1991\end{array} & 24 & 700 & 7.7 & 22.5 & -- & 193 & 59 \\ \begin{array}{l}11 \ldots \\ \text { AUG }\end{array} & 26 & 660 & 7.5 & 21.5 & - & 195 & 62 \\ \begin{array}{c}27 \ldots \\ \text { OCT }\end{array} & 5.3 & 810 & 9.1 & 25.0 & -- & 224 & 61 \\ 29 \ldots & 12 & 885 & 7.8 & 14.0 & - & 268 & 49\end{array}$

03116950 G-2 NEWMAN C NR MASSILLON OH (LAT 4049 22N LONG 08133 06W)

AUG 1989

\begin{tabular}{|c|c|c|c|c|c|c|c|}
\hline $16 \ldots$ & 3.8 & 788 & 8.0 & 22.5 & - & 215 & 100 \\
\hline OCT & & & & & & & \\
\hline $\begin{array}{c}17 \ldots \\
\text { JULY } 1990\end{array}$ & 19 & 585 & 7.9 & 16.0 & - & 263 & 94 \\
\hline $\begin{array}{c}10 \ldots \\
\text { JUNE } 1991\end{array}$ & 4.2 & 740 & 8.2 & 23.5 & -- & 211 & 100 \\
\hline AUG $^{11 \ldots}$ & 5.4 & 735 & 7.9 & 21.5 & -- & 218 & 100 \\
\hline $\mathrm{OCT}^{27 \ldots}$ & 1.2 & 680 & 8.7 & 25.5 & -- & 182 & 130 \\
\hline $29 \ldots$ & 1.7 & 845 & 7.8 & 13.0 & - & 311 & 93 \\
\hline
\end{tabular}


Table 31. Water-quality data for long-term streamwater sites, 1989-91--Continued

\begin{tabular}{|c|c|c|c|c|c|c|}
\hline Date & $\begin{array}{l}\text { Aiumi- } \\
\text { num, } \\
\text { total } \\
\text { recov- } \\
\text { erable } \\
\text { ( } \mu \text { g/L } \\
\text { as Al) }\end{array}$ & $\begin{array}{l}\text { Alumi- } \\
\text { num, } \\
\text { dls- } \\
\text { solved } \\
\text { ( } \mu \text { gl } \\
\text { as Al) }\end{array}$ & $\begin{array}{l}\text { Iron, } \\
\text { total } \\
\text { recov- } \\
\text { erable } \\
\text { ( } \mu g / \mathrm{L} \\
\text { as Fe) }\end{array}$ & $\begin{array}{c}\text { Iron, } \\
\text { dis- } \\
\text { solved } \\
(\mu \mathrm{g} / \mathrm{L} \\
\text { as Fe) }\end{array}$ & $\begin{array}{c}\text { Manga- } \\
\text { nese, } \\
\text { total } \\
\text { recov- } \\
\text { erable } \\
\text { ( } \mu \mathrm{g} / \mathrm{L} \\
\text { as } \mathrm{Mn} \text { ) }\end{array}$ & $\begin{array}{c}\text { Manga- } \\
\text { nese, } \\
\text { dls- } \\
\text { solved } \\
\text { ( } \mu g / L \\
\text { as Mn) }\end{array}$ \\
\hline
\end{tabular}

403426081211900 F-1 CONOTTON C NR SOMERDALE OH (LAT 4034 26N LONG 08121 19W)

$\begin{array}{ccccccc}\begin{array}{c}\text { AUG } 1989 \\ 16 \ldots\end{array} & 290 & 40 & 1700 & 40 & 1400 & 1200 \\ \begin{array}{c}\text { OCT } \\ 17 \ldots\end{array} & 540 & 30 & 2200 & 250 & 920 & 990 \\ \begin{array}{c}\text { JULY } 1990 \\ 11 \ldots\end{array} & 500 & 40 & 2400 & 60 & 1500 & 1500 \\ \begin{array}{c}\text { JUNE } 1991 \\ \text { O7... }\end{array} & 380 & 20 & 1700 & 50 & 1200 & 1100 \\ \begin{array}{c}\text { AUG } \\ 27 \ldots\end{array} & 560 & 30 & 1700 & 10 & 1500 & 1400 \\ \begin{array}{c}\text { OCT } \\ 29 \ldots\end{array} & 330 & 20 & 2300 & 710 & 3400 & 3600\end{array}$

03123000 G-1 SUGAR C AB BEACH CITY DAM AT BEACH CITY OH (LAT 4039 24N LONG 08134 37W)

AUG 1989

$\begin{array}{ccccccc}\begin{array}{c}16 \ldots \\ \text { OCT }\end{array} & 1100 & 30 & 2400 & 20 & 290 & 230 \\ \begin{array}{c}17 \ldots \\ \text { JULY } 1990 \\ 10 \ldots\end{array} & 1300 & 210 & 2300 & 520 & 370 & 350 \\ \begin{array}{c}\text { JUNE } 1991 \\ 11 \ldots\end{array} & 1300 & 10 & 3100 & 20 & 420 & 340 \\ \begin{array}{c}\text { AUG } \\ 27 \ldots\end{array} & 1100 & 20 & 2300 & 20 & 350 & 210 \\ \begin{array}{c}\text { OCT } \\ 29 \ldots\end{array} & 490 & <10 & 1500 & 200 & 640 & 640\end{array}$

03116950 G-2 NEWMAN C NR MASSILLON OH (LAT 4049 22N LONG 08133 06W)

\begin{tabular}{|c|c|c|c|c|c|c|}
\hline \multicolumn{7}{|l|}{ AUG 1989} \\
\hline $16 \ldots$ & 150 & 70 & 360 & 20 & 230 & 200 \\
\hline \multicolumn{7}{|l|}{ OCT } \\
\hline $\begin{array}{c}17 \ldots \\
\text { JUL Y } 1990\end{array}$ & 2100 & 80 & 3200 & 120 & 310 & 210 \\
\hline $\begin{array}{c}10 \ldots \\
\text { JUNE } 1991\end{array}$ & 160 & $<10$ & 460 & 20 & 210 & 170 \\
\hline AUG $^{11 \ldots}$ & 1200 & 20 & 2100 & 20 & 360 & 300 \\
\hline $\mathrm{OCT}^{27 \ldots}$ & 140 & 40 & 390 & 110 & 240 & 210 \\
\hline $29 . .$. & 150 & $<10$ & 550 & 40 & 270 & 280 \\
\hline
\end{tabular}


Table 31. Water-quality data for long-term streamwater sites, 1989-91--Continued

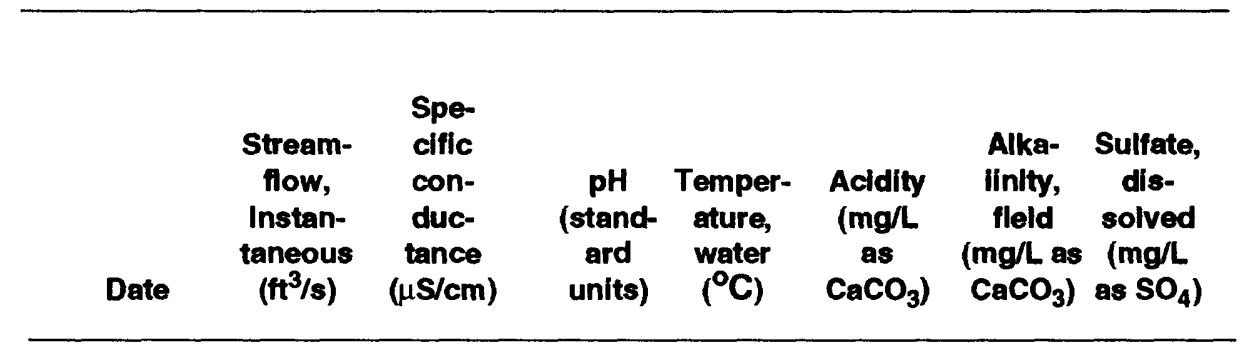

03127500 H-1 STILLWATER C AT UHRICHSVILLE OH (LAT 4023 10N LONG 08120 50W)

AUG 1989

\begin{tabular}{|c|c|c|c|c|c|c|}
\hline $\mathrm{OCT}^{16 \ldots}$ & 42 & 1200 & 8.4 & 21.5 & -- & 145 \\
\hline $\begin{array}{c}16 \ldots \\
\text { JULY } 1990\end{array}$ & 71 & 930 & 7.8 & 15.5 & -- & 113 \\
\hline $\begin{array}{c}\text { 09... } \\
\text { JUNE } 1991\end{array}$ & 93 & 1150 & 7.3 & 22.5 & -- & 131 \\
\hline${ }_{\text {AUG }}^{11 \ldots}$ & 30 & 1010 & 7.6 & 22.0 & -- & 136 \\
\hline OCT $^{27 \ldots}$ & 21 & 860 & 8.7 & 25.0 & -- & 104 \\
\hline $28 \ldots$ & 19 & 1150 & 7.6 & 14.0 & - & 277 \\
\hline
\end{tabular}

03129100 I-1 WHITE EYES C NR FRESNO OH (LAT 4018 17N LONG 08145 01W)

AUG 1989

$\begin{array}{cccccccc}15 \ldots & 4.1 & 940 & 7.4 & 21.0 & - & 99 & 73 \\ \begin{array}{c}\text { OCT } \\ 16 \ldots\end{array} & 3.5 & 510 & 7.4 & 15.0 & -- & 159 & 87 \\ \begin{array}{c}\text { AUG } 1990 \\ \quad 17 \ldots\end{array} & 8.6 & 415 & 7.6 & 22.5 & -- & 95 & 69 \\ \begin{array}{c}\text { JUNE } 1991 \\ \quad 11 \ldots\end{array} & 4.4 & 420 & 7.5 & 23.0 & - & 119 & 70 \\ \text { AUG } & & & & & & \\ \quad 26 \ldots & .37 & 380 & 8.1 & 28.0 & -- & 57 & 63 \\ \text { OCT } 28 \ldots & 1.3 & 480 & 7.3 & 15.0 & -- & 122 & 80\end{array}$

401624081363400 I-2 BUCKHORN C AT NEWCOMERSTOWN OH (LAT 4016 24N LONG 081 36 34W)

AUG 1989

$\begin{array}{lllllllr}\begin{array}{l}15 \ldots \\ \text { OCT }\end{array} & 1.3 & 535 & 8.1 & 19.0 & - & 89 & 120 \\ \quad 16 \ldots & 1.4 & 550 & 7.7 & 16.0 & - & 101 & 120 \\ \begin{array}{c}\text { JULY } 1990 \\ \quad 09 \ldots\end{array} & 4.7 & 465 & 7.5 & 24.5 & - & 59 & 95 \\ \begin{array}{c}\text { JUNE } 1991 \\ \quad 11 \ldots\end{array} & 1.4 & 480 & 7.6 & 22.0 & - & 85 & 110 \\ \text { AUG } & & & & & & & \\ \quad 26 \ldots & .11 & 575 & 8.1 & 24.5 & - & 100 & 150 \\ \begin{array}{c}\text { OCT } \\ 28 \ldots\end{array} & 1.1 & 575 & 7.4 & 15.0 & - & 139 & 110\end{array}$


Table 31. Water-quality data for long-term streamwater sites, 1989-91--Continued

\begin{tabular}{|c|c|c|c|c|c|c|}
\hline Date & $\begin{array}{c}\text { Aluml- } \\
\text { num, } \\
\text { totai } \\
\text { recov- } \\
\text { erable } \\
\text { ( } \mu g / \mathrm{L} \\
\text { as Al) }\end{array}$ & $\begin{array}{l}\text { Aluml- } \\
\text { num, } \\
\text { dls- } \\
\text { solved } \\
\text { ( } \mu \mathrm{g} / \mathrm{A} \\
\text { as Al) }\end{array}$ & $\begin{array}{l}\text { Iron, } \\
\text { total } \\
\text { recov- } \\
\text { erable } \\
\text { ( } \mu \mathrm{g} / \\
\text { as Fe) }\end{array}$ & $\begin{array}{l}\text { Iron, } \\
\text { dls- } \\
\text { solved } \\
\text { ( } \mu \mathrm{g} / \mathrm{L} \\
\text { as Fe) }\end{array}$ & $\begin{array}{c}\text { Manga- } \\
\text { nese, } \\
\text { total } \\
\text { recov- } \\
\text { erable } \\
(\mu g / L \\
\text { as Mn) }\end{array}$ & $\begin{array}{c}\text { Manga- } \\
\text { nese, } \\
\text { dis- } \\
\text { solved } \\
\text { ( } \mu \mathrm{g} / \mathrm{L} \\
\text { as } \mathrm{Mn} \text { ) }\end{array}$ \\
\hline
\end{tabular}

03127500 H-1 STILLWATER C AT UHRICHSVILLE OH (LAT 4023 10N LONG 08120 50W)

$\begin{array}{ccccccc}\begin{array}{c}\text { AUG } 1989 \\ 16 \ldots\end{array} & 250 & 70 & 380 & 10 & 460 & 350 \\ \begin{array}{c}16 . \ldots \\ \text { OCT }\end{array} & 440 & 40 & 670 & 20 & 290 & 220 \\ \begin{array}{c}\text { JULY } 1990 \\ \quad 09 \ldots\end{array} & 300 & 10 & 600 & 20 & 380 & 240 \\ \begin{array}{c}\text { JUNE } 1991 \\ \quad 11 \ldots\end{array} & 290 & 30 & 440 & 100 & 610 & 450 \\ \begin{array}{c}\text { AUG } \\ 27 \ldots\end{array} & 90 & 20 & 170 & 130 & 620 & 530 \\ \begin{array}{c}\text { OCT } \\ 28 \ldots\end{array} & 110 & 10 & 320 & 50 & 600 & 620\end{array}$

03129100 I-1 WHITE EYES C NR FRESNO OH (LAT 4018 17N LONG 08145 01W)

AUG 1989

$\begin{array}{ccccccc}\begin{array}{c}15 \ldots \\ \text { OCT }\end{array} & 260 & 40 & 2200 & 70 & 720 & 730 \\ 16 \ldots & 410 & 50 & 2500 & 450 & 420 & 440 \\ \begin{array}{c}\text { AUG } 1990 \\ 17 \ldots\end{array} & 200 & 40 & 1600 & 40 & 300 & 310 \\ \begin{array}{c}\text { JUNE } 1991 \\ 11 \ldots\end{array} & 230 & 20 & 1800 & 160 & 500 & 540 \\ \begin{array}{c}\text { AUG } \\ 26 \ldots\end{array} & 80 & 20 & 1500 & 20 & 460 & 410 \\ \begin{array}{c}\text { OCT } \\ 28 \ldots\end{array} & 100 & 20 & 4300 & 1500 & 2900 & 3100\end{array}$

401624081363400 I-2 BUCKHORN C AT NEWCOMERSTOWN OH (LAT 4016 24N LONG 081 36 34W)

$\begin{array}{lrrrrrr}\begin{array}{c}\text { AUG } 1989 \\ 15 \ldots\end{array} & 130 & 50 & 470 & 30 & 370 & 340 \\ \begin{array}{c}\text { OCT } \\ 16 \ldots\end{array} & 280 & 70 & 600 & 360 & 380 & 380 \\ \begin{array}{c}\text { JULY } 1990 \\ \quad 09 \ldots\end{array} & 810 & 30 & 2000 & 80 & 700 & 560 \\ \begin{array}{c}\text { JUNE } 1991 \\ \quad 11 \ldots\end{array} & 160 & 20 & 530 & 200 & 300 & 290 \\ \begin{array}{c}\text { AUG } \\ \quad 26 \ldots\end{array} & 90 & 20 & 410 & 50 & 220 & 150 \\ \begin{array}{c}\text { OCT } \\ 28 \ldots\end{array} & 140 & 10 & 370 & 240 & 2500 & 2600\end{array}$


Table 31. Water-quality data for long-term streamwater sites, 1989-91--Continued

\begin{tabular}{|c|c|c|c|c|c|c|c|}
\hline Date & $\begin{array}{c}\text { Stream- } \\
\text { flow, } \\
\text { Instan- } \\
\text { taneous } \\
\left(\mathrm{ft}^{3} / \mathrm{s}\right)\end{array}$ & $\begin{array}{l}\text { Spe- } \\
\text { cific } \\
\text { con- } \\
\text { duc- } \\
\text { tance } \\
(\mu S / \mathrm{cm})\end{array}$ & $\begin{array}{c}\text { pH } \\
\text { (stand- } \\
\text { ard } \\
\text { unlts) }\end{array}$ & $\begin{array}{c}\text { Temper- } \\
\text { ature, } \\
\text { water } \\
\left.{ }^{\circ} \mathrm{C}\right)\end{array}$ & $\begin{array}{c}\text { Acldity } \\
\text { (mg/L } \\
\text { as } \\
\left.\mathrm{CaCO}_{3}\right)\end{array}$ & $\begin{array}{c}\text { Alka- } \\
\text { Ilnity, } \\
\text { field } \\
\left(\mathrm{mg}^{\prime} \mathrm{L} \text { as }\right. \\
\left.\mathrm{CaCO}_{3}\right)\end{array}$ & 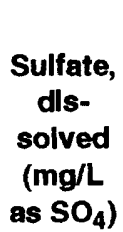 \\
\hline
\end{tabular}

$03140000 \quad$ J-1 MILL C NR COSHOCTON OH (LAT 4021 46N LONG 08151 45W)

AUG 1989

$\begin{array}{cccccccc}15 \ldots & 2.1 & 368 & 7.5 & 21.5 & - & 116 & 50 \\ \begin{array}{c}\text { OCT } \\ 17 \ldots\end{array} & 2.2 & 425 & 7.5 & 16.0 & - & 105 & 60 \\ \text { AUG } 1990 & & & & & & \\ \quad 17 \ldots & 4.8 & 370 & 7.6 & 19.5 & - & 100 & 13 \\ \begin{array}{c}\text { JUNE } 1991 \\ \quad 06 \ldots\end{array} & 2.5 & 380 & 7.8 & 19.0 & - & 101 & 56 \\ \begin{array}{c}\text { AUG } \\ \quad 26 \ldots\end{array} & .19 & 390 & 7.8 & 23.0 & - & 108 & 38 \\ \text { OCT } & & & & & & \\ 28 \ldots & .62 & 450 & 7.4 & 14.5 & - & 132 & 40\end{array}$

401936082001400 J-2 SIMMONS RN NR WARSAW OH (LAT 4019 36N LONG 08200 14W)

\begin{tabular}{|c|c|c|c|c|c|c|c|}
\hline $\begin{array}{c}\text { AUG } 1989 \\
15 \ldots\end{array}$ & 1.2 & 1280 & 7.6 & 21.5 & -- & 112 & 630 \\
\hline OCT & & & & & & & \\
\hline $\begin{array}{c}17 \ldots \\
\text { JULY } 1990\end{array}$ & 2.2 & 1180 & 7.6 & 15.0 & -- & 102 & 570 \\
\hline $\begin{array}{c}09 \ldots \\
\text { JUNE } 1991\end{array}$ & 2.0 & 940 & 7.9 & 24.5 & -- & 102 & 400 \\
\hline $\begin{array}{l}10 \ldots \\
\text { AUG }\end{array}$ & 1.1 & 1290 & 7.6 & 21.5 & - & 100 & \\
\hline OCT $^{26 \ldots}$ & .09 & 1820 & 7.4 & 22.5 & -- & 87 & 10 \\
\hline $28 \ldots$ & .85 & 1700 & 7.4 & 14.0 & - & 110 & 1100 \\
\hline
\end{tabular}

395417081323000 K-1 WILLS C AT PLEASANT CITY OH (LAT 3954 17N LONG 08132 30W)

$\begin{array}{lccccccc}\begin{array}{l}\Lambda U G ~ 1989 \\ 15 \ldots\end{array} & 12 & 2200 & 8.3 & 21.5 & - & 236 & 1300 \\ \begin{array}{c}\text { OCT } \\ 16 \ldots\end{array} & 32 & 1400 & 8.0 & 16.0 & - & 198 & 600 \\ \begin{array}{c}\text { SEPT } 1990 \\ \quad 05 \ldots\end{array} & 25 & 1600 & 8.0 & 22.5 & - & 195 & 640 \\ \begin{array}{c}\text { JUNE } 1991 \\ \quad 11 \ldots\end{array} & 9.9 & 2900 & 8.2 & 22.5 & - & 269 & 1800 \\ \begin{array}{c}\text { AUG } \\ 26 \ldots\end{array} & 7.2 & 2950 & 8.2 & 23.5 & - & 305 & 1600 \\ \begin{array}{c}\text { OCT } \\ 23 \ldots\end{array} & 5.3 & 3350 & 7.9 & 13.0 & - & 391 & 1700\end{array}$


Table 31. Water-quality data for long-term streamwater sites, 1989-91--Continued

\begin{tabular}{|c|c|c|c|c|c|c|}
\hline Date & $\begin{array}{l}\text { Alumi- } \\
\text { num, } \\
\text { total } \\
\text { recov- } \\
\text { erabie } \\
\text { ( } \mu \mathrm{g} / \mathrm{L} \\
\text { as Al) }\end{array}$ & $\begin{array}{l}\text { Aiumi- } \\
\text { num, } \\
\text { dis- } \\
\text { soived } \\
\text { ( } \mu g \text { / } \\
\text { as } \mathrm{Al} \text { ) }\end{array}$ & $\begin{array}{l}\text { Iron, } \\
\text { total } \\
\text { recov- } \\
\text { erable } \\
\text { ( } \mu \mathrm{g} / \mathrm{L} \\
\text { as Fe) }\end{array}$ & $\begin{array}{l}\text { iron, } \\
\text { dis- } \\
\text { soived } \\
\text { ( } \mu \mathrm{g} / \mathrm{l} \\
\text { as Fe) }\end{array}$ & $\begin{array}{c}\text { Manga- } \\
\text { nese, } \\
\text { total } \\
\text { recov- } \\
\text { erable } \\
\text { ( } \mu g / L \\
\text { as Mn) }\end{array}$ & $\begin{array}{c}\text { Manga- } \\
\text { nese, } \\
\text { dis- } \\
\text { soived } \\
(\mu g / L \\
\text { as Mn) }\end{array}$ \\
\hline
\end{tabular}

$03140000 \quad$ J-1 MILL C NR COSHOCTON OH (LAT 40 21 46N LONG $0815145 \mathrm{~W}$ )

$\begin{array}{lllllll}\begin{array}{c}\text { AUG } 1989 \\ 15 \ldots\end{array} & 160 & 40 & 1400 & 90 & 220 & 200 \\ \begin{array}{c}\text { OCT } \\ 17 \ldots\end{array} & 360 & <10 & 1600 & 290 & 310 & 260 \\ \begin{array}{c}\text { AUG } 1990 \\ 17 \ldots\end{array} & 110 & <10 & 1000 & 100 & 180 & 180 \\ \begin{array}{c}\text { JUNE } 1991 \\ \text { 06... }\end{array} & 160 & 10 & 1300 & 130 & 220 & 220 \\ \begin{array}{c}\text { AUG } \\ 26 \ldots\end{array} & 230 & 10 & 1800 & 230 & 570 & 520 \\ \begin{array}{c}\text { OCT } \\ 28 \ldots\end{array} & 200 & <10 & 1800 & 140 & 340 & 370\end{array}$

401936082001400 J-2 SIMMONS RN NR WARSAW OH (LAT 4019 36N LONG 08200 14W)

$\begin{array}{llccccr}\begin{array}{c}\text { AUG } 1989 \\ 15 \ldots\end{array} & 270 & 50 & 590 & 10 & 270 & 200 \\ \begin{array}{c}\text { OCT } \\ 17 \ldots\end{array} & 250 & 20 & 320 & 70 & 260 & 180 \\ \begin{array}{c}\text { JULY } 1990 \\ 09 \ldots\end{array} & 130 & <10 & 370 & <10 & 310 & 10 \\ \begin{array}{l}\text { JUNE } 1991 \\ 10 \ldots\end{array} & 120 & 10 & 420 & 110 & 230 & 190 \\ \begin{array}{c}\text { AUG } \\ 26 \ldots\end{array} & 390 & 20 & 880 & 100 & 810 & 720 \\ \begin{array}{c}\text { OCT } \\ 28 \ldots\end{array} & 180 & <10 & 330 & <10 & 200 & 190\end{array}$

395417081323000 K-1 WIL.LS C AT PLEASANT CITY OH (LAT 3954 17N LONG 08132 30W)

$\begin{array}{ccccccc}\begin{array}{c}\text { AUG } 1989 \\ 15 \ldots\end{array} & 560 & 70 & 680 & 20 & 240 & 190 \\ \begin{array}{c}\text { OCT } \\ 16 \ldots\end{array} & 700 & 30 & 840 & 100 & 270 & 140 \\ \begin{array}{c}\text { SEPT } 1990 \\ \text { 05... }\end{array} & 810 & 30 & 1400 & 20 & 250 & 130 \\ \begin{array}{c}\text { JUNE } 1991 \\ 11 \ldots\end{array} & 620 & 20 & 830 & 20 & 230 & 130 \\ \begin{array}{c}\text { AUG } \\ 26 \ldots\end{array} & 770 & 20 & 1200 & 80 & 240 & 100 \\ \begin{array}{c}\text { OCT } \\ 23 \ldots\end{array} & 310 & 10 & 310 & <10 & 110 & 60\end{array}$


Table 31. Water-quality data for long-term streamwater sites, 1989-91--Continued

\begin{tabular}{|c|c|c|c|c|c|c|}
\hline Date & $\begin{array}{l}\text { Stream- } \\
\text { flow, } \\
\text { instan- } \\
\text { taneous } \\
\left(\mathrm{ft}^{3} / \mathrm{s}\right)\end{array}$ & $\begin{array}{l}\text { Spe- } \\
\text { ciflc } \\
\text { con- } \\
\text { duc- } \\
\text { tance } \\
(\mu S / c m)\end{array}$ & $\begin{array}{l}\text { pH } \\
\text { (stand- } \\
\text { ard } \\
\text { units) }\end{array}$ & $\begin{array}{c}\text { Temper- } \\
\text { ature, } \\
\text { water } \\
\left({ }^{\circ} \mathrm{C}\right)\end{array}$ & $\begin{array}{c}\text { Acidlty } \\
\text { (mg/L } \\
\text { as } \\
\left.\mathrm{CaCO}_{3}\right)\end{array}$ & 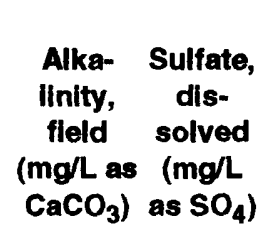 \\
\hline
\end{tabular}

400117081362600 L-1 CROOKED C NR CAMBRIDGE OH (LAT 4001 17N LONG 08136 26W)

$\begin{array}{llllllll}\begin{array}{c}\text { AUG } 1989 \\ 15 \ldots\end{array} & 1.7 & 720 & 8.1 & 25.0 & - & 148 & 180 \\ \begin{array}{c}\text { OCT } \\ 17 \ldots\end{array} & 5.1 & 640 & 7.5 & 17.0 & -- & 148 & 140 \\ \begin{array}{c}\text { AUG } 1990 \\ 17 \ldots\end{array} & 10 & 525 & 7.9 & 23.5 & - & 152 & 93 \\ \begin{array}{c}\text { JUNE } 1991 \\ 17 \ldots\end{array} & 1.1 & 690 & 7.5 & 23.5 & -- & 151 & 190 \\ \begin{array}{c}\text { AUG } \\ 26 \ldots\end{array} & .46 & 710 & 8.0 & 22.5 & - & 116 & 140 \\ \begin{array}{c}\text { OCT } \\ 23 \ldots\end{array} & .56 & 1220 & 7.6 & 13.5 & - & 199 & 350\end{array}$

400920081432900 L-2 WHITE EYES C NR PLAINFIELD OH (LAT 4009 20N LONG 08143 29W)

$\begin{array}{llllllll}\begin{array}{c}\text { AUG } 1989 \\ 15 \ldots\end{array} & 4.2 & 1000 & 7.7 & 24.0 & - & 99 & 530 \\ \begin{array}{c}\text { OC } \Gamma \\ 16 \ldots\end{array} & 5.1 & 965 & 7.4 & 18.0 & - & 98 & 390 \\ \begin{array}{c}\text { AUG } 1990 \\ 17 \ldots\end{array} & 9.0 & 845 & 7.7 & 22.0 & - & 99 & 380 \\ \begin{array}{c}\text { JUNE } 1991 \\ 17 \ldots\end{array} & 4.1 & 1130 & 7.5 & 23.5 & -- & 98 & 520 \\ \begin{array}{c}\text { AUG } \\ 26 \ldots\end{array} & 1.2 & 1100 & 8.1 & 21.5 & - & 82 & 600 \\ \begin{array}{c}\text { OCT } \\ 24 \ldots\end{array} & 2.1 & 1350 & 7.2 & 12.0 & -- & 89 & 620\end{array}$

400710082081000 M-1 WAKATOMIKA C NR FRAZEYSBURG OH (LAT 4106 16N LONG 08207 55W)

\begin{tabular}{|c|c|c|c|c|c|c|c|}
\hline AUG 1989 & & & & & & & \\
\hline $15 \ldots$ & 16 & 377 & 7.6 & 22.5 & -- & 94 & 19 \\
\hline OCT & & & & & & & \\
\hline $\begin{array}{c}17 \ldots \\
\text { JULY } 1990\end{array}$ & 18 & 430 & 7.6 & 15.5 & -- & 109 & 21 \\
\hline $\begin{array}{c}09 \ldots \\
\text { JUNE } 1991\end{array}$ & 26 & 345 & 7.8 & 24.5 & - & 91 & \\
\hline $06 \ldots$ & 22 & 330 & 8.2 & 21.5 & - & 82 & 17 \\
\hline AUG & & & & & & & \\
\hline $26 \ldots$ & 5.8 & 365 & 7.7 & 23.0 & - & 97 & 15 \\
\hline OCT & & & & & & & \\
\hline $28 \ldots$ & 8.0 & 415 & 7.3 & 14.5 & - & 122 & 19 \\
\hline
\end{tabular}


Table 31. Water-quality data for long-term streamwater sites, 1989-91--Continued

\begin{tabular}{|c|c|c|c|c|c|c|}
\hline Date & $\begin{array}{l}\text { Alumi- } \\
\text { num, } \\
\text { total } \\
\text { recov- } \\
\text { erable } \\
\text { ( } \mu g / \text { L } \\
\text { as Al) }\end{array}$ & $\begin{array}{l}\text { Alumi- } \\
\text { num, } \\
\text { dls- } \\
\text { solved } \\
\text { ( } \mu \text { gl } \\
\text { as Al) }\end{array}$ & $\begin{array}{l}\text { Iron, } \\
\text { total } \\
\text { recov- } \\
\text { erable } \\
\text { ( } \mu \mathrm{g} / \mathrm{L} \\
\text { as Fe) }\end{array}$ & $\begin{array}{l}\text { Iron, } \\
\text { dls- } \\
\text { solved } \\
\text { ( } \mu \mathrm{g} / \mathrm{L} \\
\text { as Fe) }\end{array}$ & $\begin{array}{c}\text { Manga- } \\
\text { nese, } \\
\text { total } \\
\text { recov- } \\
\text { erable } \\
\text { ( } \mu g / L \\
\text { as Mn) }\end{array}$ & $\begin{array}{l}\text { Manga- } \\
\text { nese, } \\
\text { dls- } \\
\text { solved } \\
\text { ( } \mu g / 2 \\
\text { as Mn) }\end{array}$ \\
\hline
\end{tabular}

400117081362600 L-1 CROOKED C NR CAMBRIDGE OH (LAT 4001 17N LONG 08136 26W)

$\begin{array}{lrrrrrr}\begin{array}{c}\text { AUG } 1989 \\ 15 \ldots\end{array} & 610 & 20 & 970 & 20 & 270 & 210 \\ \begin{array}{c}\text { OCT } \\ 17 \ldots\end{array} & 590 & 30 & 930 & 90 & 570 & 500 \\ \begin{array}{c}\text { AUG } 1990 \\ \quad 17 \ldots\end{array} & 1400 & 40 & 2100 & 20 & 300 & 230 \\ \begin{array}{c}\text { JUNE } 1991 \\ \quad 17 \ldots\end{array} & 660 & <10 & 1300 & 260 & 820 & 670 \\ \begin{array}{c}\text { AUG } \\ \quad 26 \ldots\end{array} & 400 & 10 & 870 & 180 & 670 & 580 \\ \text { OCT } 23 \ldots & 210 & <10 & 640 & 50 & 1300 & 1300 \\ 23 \ldots & & \end{array}$

400920081432900 L-2 WHITE EYES C NR PLAINFIELD OH (LAT 4009 20N LONG 08143 29W)

AUG 1989

\begin{tabular}{|c|c|c|c|c|c|c|}
\hline${ }_{\text {OCT }}^{15 \ldots}$ & 250 & 40 & 930 & 20 & 800 & 720 \\
\hline $\begin{array}{c}16 \ldots \\
\text { AUG } 1990\end{array}$ & 360 & 20 & 1300 & 190 & 780 & 680 \\
\hline $\begin{array}{c}17 \ldots \\
\text { JUNE } 1991\end{array}$ & 110 & 30 & 560 & 20 & 700 & 780 \\
\hline AUG $^{17 \ldots}$ & 420 & 20 & 1200 & 30 & 720 & 770 \\
\hline $\mathrm{OCT}^{26 \ldots}$ & 240 & 20 & 940 & 20 & 900 & 700 \\
\hline $24 \ldots$ & 160 & $<10$ & 920 & 360 & 840 & 890 \\
\hline
\end{tabular}

400710082081000 M-1 WAKATOMIKA C NR FRAZEYSBURG OH (LAT 4106 16N LONG 08207 55W)

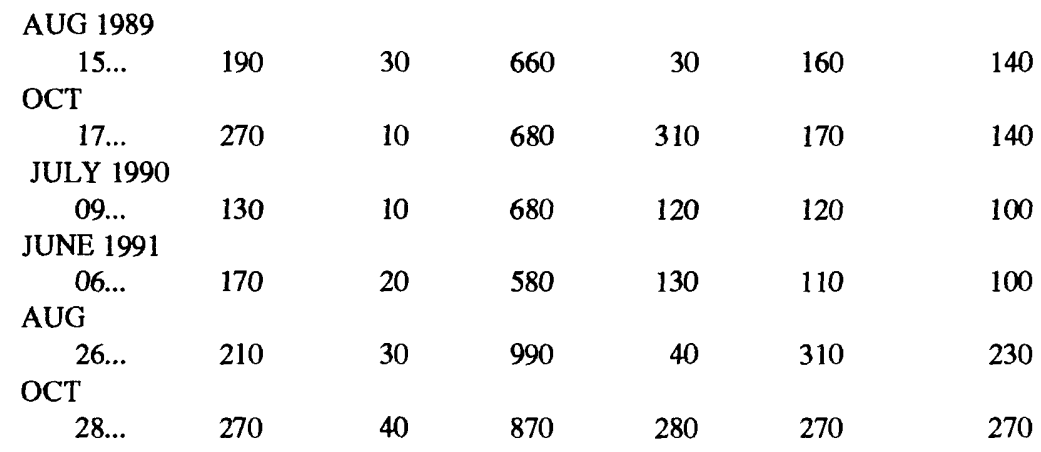


Table 31. Water-quality data for long-term streamwater sites, 1989-91--Continued

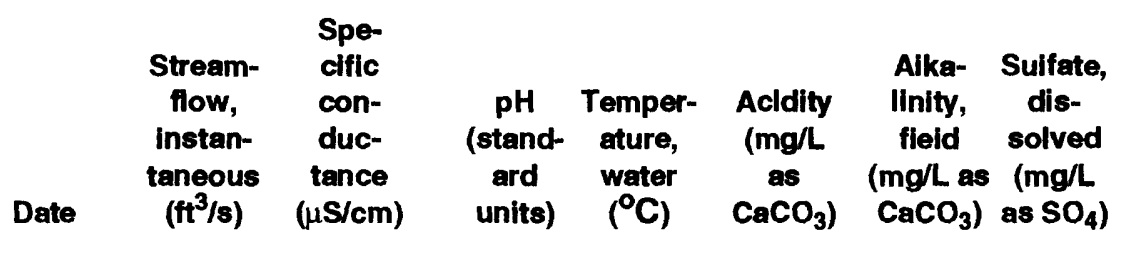

400912082014700 M-2 LITTLE WAKATOMIKA C NR TRINWAY OH (LAT 4009 12N LONG 08201 47W)

\begin{tabular}{|c|c|c|c|c|c|c|c|}
\hline AUG 1989 & & & & & & & \\
\hline${ }_{\text {OCT }}^{15 \ldots . .}$ & 9.2 & 1250 & 8.0 & 22.0 & -- & 79 & 820 \\
\hline $\begin{array}{c}17 \ldots \\
\text { JULY } 1990\end{array}$ & 9.7 & 1580 & 7.5 & 16.0 & -- & 81 & 870 \\
\hline $\begin{array}{c}09 \ldots \\
\text { JUNE } 1991\end{array}$ & 15 & 1180 & 7.8 & 23.5 & - & 77 & 570 \\
\hline $\begin{array}{c}06 \ldots \\
\text { AUG }\end{array}$ & 12 & 1550 & 7.9 & 18.5 & -- & 78 & \\
\hline OCT & 2.5 & 1980 & 8.0 & 23.5 & - & 64 & \\
\hline $28 \ldots$ & 5.3 & 2000 & 7.2 & 14.0 & -- & 78 & 300 \\
\hline
\end{tabular}

03149500 N-1 SALT C NR CHANDLERSVILLE OH (LAT 3954 31N LONG 08151 38W)

$\begin{array}{llllllll}\begin{array}{c}\text { AUG } 1989 \\ 14 \ldots\end{array} & 4.4 & 645 & 7.8 & 24.0 & - & 122 & 120 \\ \begin{array}{l}\text { OCT } \\ \quad 18 \ldots\end{array} & 10 & 585 & 7.3 & 11.0 & - & 138 & 87 \\ \begin{array}{c}\text { SEPT } 1990 \\ \quad 05 \ldots\end{array} & 11 & 480 & 8.1 & 24.0 & - & 152 & 67 \\ \begin{array}{c}\text { JUNE } 1991 \\ \quad 11 . .\end{array} & 4.7 & 500 & 8.0 & 23.5 & - & 110 & 100 \\ \begin{array}{c}\text { AUG } \\ \quad 27 \ldots\end{array} & .62 & 565 & 8.0 & 19.5 & - & 24 & 86 \\ \begin{array}{c}\text { OCT } \\ 24 \ldots\end{array} & .21 & 750 & 7.6 & 14.0 & - & 139 & 170\end{array}$

$03150250 \quad \mathrm{~N}-2$ MEIGS C NR BEVERLY OH (LAT 3936 00N LONG 08142 42W)

$\begin{array}{llllllll}\begin{array}{c}\text { AUG } 1989 \\ 14 \ldots\end{array} & 25 & 1300 & 7.8 & 22.0 & - & 180 & 570 \\ \begin{array}{c}\text { OCT } \\ 16 \ldots\end{array} & 34 & 1230 & 8.1 & 16.0 & - & 100 & 500 \\ \begin{array}{c}\text { SEPT } 1990 \\ \quad 05 \ldots\end{array} & -- & 1100 & 7.8 & 22.5 & - & 175 & 470 \\ \begin{array}{c}\text { JUNE } 1991 \\ \quad 11 . .\end{array} & 4.3 & 1600 & 8.2 & 21.5 & - & 166 & 360 \\ \begin{array}{c}\text { AUG } \\ \quad 26 \ldots\end{array} & 3.5 & 1300 & 8.3 & 25.5 & - & 35 & 920 \\ \begin{array}{c}\text { OCT } \\ 23 \ldots\end{array} & 2.2 & 2100 & 7.7 & 13.5 & - & 167 & 1100\end{array}$


Table 31. Water-quality data for long-term streamwater sites, 1989-91--Continued

\begin{tabular}{|c|c|c|c|c|c|c|}
\hline Date & $\begin{array}{l}\text { Alumi- } \\
\text { num, } \\
\text { total } \\
\text { recov- } \\
\text { erable } \\
\text { ( } \mu g / \\
\text { as AI) }\end{array}$ & $\begin{array}{l}\text { Alumi- } \\
\text { num, } \\
\text { dis- } \\
\text { soived } \\
\text { ( } \mu \mathrm{g} / \\
\text { as Al) }\end{array}$ & $\begin{array}{l}\text { Iron, } \\
\text { totai } \\
\text { recov- } \\
\text { erable } \\
\text { ( } \mu g / L \\
\text { as Fe) }\end{array}$ & $\begin{array}{c}\text { iron, } \\
\text { dis- } \\
\text { solved } \\
\text { ( } \mu \text { g/L } \\
\text { as Fe) }\end{array}$ & $\begin{array}{c}\text { Manga- } \\
\text { nese, } \\
\text { total } \\
\text { recov- } \\
\text { erable } \\
\text { ( } \mu g / L \\
\text { as } M n)\end{array}$ & $\begin{array}{l}\text { Manga- } \\
\text { nese, } \\
\text { dis- } \\
\text { solved } \\
\text { ( } \mu g / \mathbf{L} \\
\text { as Mn) }\end{array}$ \\
\hline
\end{tabular}

400912082014700 M-2 LITTLE WAKATOMIKA C NR TRINWAY OH (LAT 4009 12N LONG 08201 47W)

$\begin{array}{lcccccc}\begin{array}{c}\text { AUG } 1989 \\ 15 \ldots\end{array} & 160 & 50 & 440 & 20 & 600 & 470 \\ \begin{array}{c}\text { OCT } \\ 17 \ldots\end{array} & 40 & 20 & 310 & 100 & 770 & 650 \\ \begin{array}{c}\text { JULY } 1990 \\ 09 \ldots\end{array} & 140 & <10 & 410 & 20 & 560 & 490 \\ \begin{array}{c}\text { JUNE } 1991 \\ 06 \ldots\end{array} & 140 & <10 & 600 & <10 & 1200 & 1200 \\ \begin{array}{c}\text { AUG } \\ 26 \ldots\end{array} & 60 & 10 & 310 & 100 & 850 & 820 \\ \begin{array}{c}\text { OCT } \\ 28 \ldots\end{array} & 120 & <10 & 260 & 70 & 1200 & 1300\end{array}$

$03149500 \quad$ N-1 SALT C NR CHANDLERSVILLE OH (LAT 3954 31N LONG 08151 38W)

$\begin{array}{lcccccc}\begin{array}{c}\text { AUG } 1989 \\ 14 \ldots\end{array} & 490 & 30 & 920 & 20 & 360 & 290 \\ \begin{array}{c}\text { OCT } \\ 18 \ldots\end{array} & 390 & 50 & 720 & 140 & 310 & 380 \\ \begin{array}{c}\text { SEPT } 1990 \\ \text { 05... }\end{array} & 150 & 10 & 640 & 60 & 220 & 210 \\ \begin{array}{c}\text { JUNE } 1991 \\ 11 \ldots\end{array} & 160 & 50 & 590 & 100 & 390 & 400 \\ \begin{array}{c}\text { AUG } \\ 27 \ldots\end{array} & 280 & <10 & 930 & 110 & 530 & 390 \\ \begin{array}{c}\text { OCT } \\ 24 \ldots\end{array} & 420 & <10 & 1500 & 100 & 970 & 950\end{array}$

$03150250 \quad$ N-2 MEIGS C NR BEVERLY OH (LAT 3936 OON LONG 08142 42W)

$\begin{array}{llccccc}\begin{array}{c}\text { AUG } 1989 \\ 14 \ldots\end{array} & 360 & 90 & 590 & 120 & 90 & 40 \\ \begin{array}{c}\text { OCT } \\ 16 \ldots\end{array} & 130 & 30 & 270 & 30 & 60 & 30 \\ \begin{array}{c}\text { SEPT } 1990 \\ \text { 05... }\end{array} & 820 & 10 & 1500 & 20 & 120 & 20 \\ \begin{array}{c}\text { JUNE } 1991 \\ 11 \ldots\end{array} & 320 & 40 & 540 & 110 & 100 & 30 \\ \begin{array}{c}\text { AUG } \\ 26 \ldots\end{array} & 250 & 20 & 220 & <10 & 90 & 20 \\ \begin{array}{c}\text { OCT } \\ 23 \ldots\end{array} & 70 & <10 & 130 & <10 & 100 & 100\end{array}$


Table 31. Water-quality data for long-term streamwater sites, 1989-91--Continued

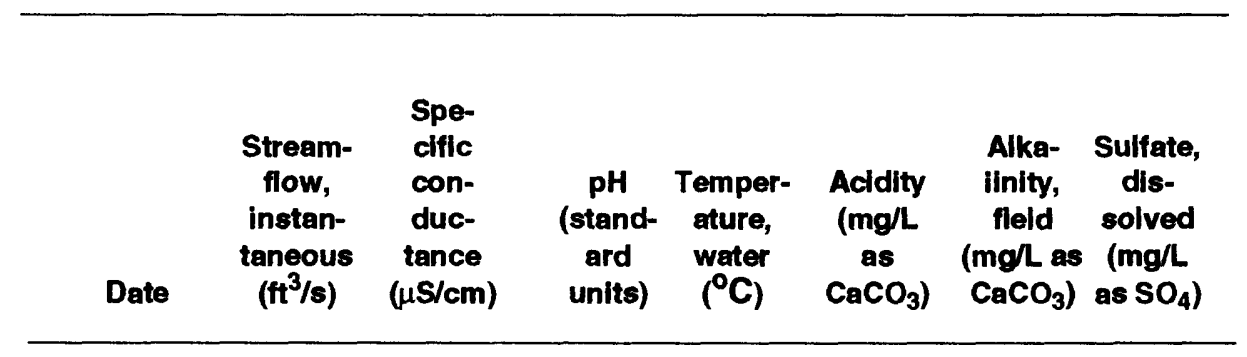

395337082011100 O-1 MOXAHALA C NR DARLINGTON OH (LAT 3953 37N LONG $0820111 \mathrm{~W}$ )

AUG 1989

\begin{tabular}{|c|c|c|c|c|c|c|c|}
\hline $15 \ldots$ & 63 & 1200 & 6.7 & 21.5 & -- & 16 & 610 \\
\hline OCT & & & & & & & \\
\hline $\begin{array}{c}17 \ldots \\
\text { SEPT } 1990\end{array}$ & 107 & 1310 & 5.8 & 16.5 & 21 & 15 & 630 \\
\hline $\begin{array}{c}05 \ldots \\
\text {. }\end{array}$ & 39 & 1320 & 6.4 & 24.0 & - & 12 & 590 \\
\hline $\begin{array}{l}11 \ldots \\
\text { AUG }\end{array}$ & 46 & 1200 & 6.7 & 23.0 & -- & 31 & 630 \\
\hline OCT $^{27 . .}$ & 18 & 1600 & 5.9 & 21.0 & 6.0 & 4 & 810 \\
\hline $24 \ldots$ & 12 & 2000 & 4.5 & 14.0 & 50 & - & 1100 \\
\hline
\end{tabular}

03148400 O-2 MOXAHALA C AT ROBERTS OH (LAT 3951 17N LONG 08203 23W)

AUG 1989

$\begin{array}{llllllll}15 \ldots & 27 & 1600 & 2.7 & 19.0 & 153 & - & 1000 \\ \begin{array}{l}\text { OCT } \\ 17 \ldots\end{array} & 68 & 1550 & 3.3 & 17.0 & 88 & - & 820 \\ \begin{array}{c}\text { SEPT } 1990 \\ \quad 05 \ldots\end{array} & 20 & 1800 & 3.2 & 22.5 & 137 & - & 890 \\ \begin{array}{c}\text { JUNE } 1991 \\ \quad 12 \ldots\end{array} & 37 & 1700 & 3.4 & 20.5 & 181 & - & 950 \\ \begin{array}{l}\text { AUG } \\ \quad 27 \ldots\end{array} & 11 & 1900 & 3.4 & 21.0 & 111 & - & 1100 \\ \text { OCT } & & & & & & & \\ 24 \ldots & 9.7 & 2180 & 3.2 & 15.0 & 150 & - & 1400\end{array}$

395214082054700 O-3 JONATHAN C AT WHITE COTTAGE OH (LAT 3952 14N LONG 08205 47W)

AUG 1989

$\begin{array}{cccccccc}14 \ldots & 33 & 830 & 8.1 & 24.0 & - & 133 & 240 \\ \begin{array}{c}\text { OCT } \\ 18 \ldots\end{array} & 42 & 900 & 7.0 & 13.0 & -- & 111 & 300 \\ \begin{array}{c}\text { SEPT } 1990 \\ \quad 05 \ldots\end{array} & 13 & 975 & 8.1 & 24.0 & - & 114 & 340 \\ \begin{array}{c}\text { JUNE } 1991 \\ \quad 12 \ldots\end{array} & 31 & 1100 & 8.1 & 22.5 & - & 110 & 360 \\ \begin{array}{c}\text { AUG } \\ \quad 27 \ldots\end{array} & 4.7 & 1800 & 8.2 & 25.5 & - & 72 & 830 \\ \begin{array}{c}\text { OCT } \\ 24 . . .\end{array} & 4.1 & 2180 & 7.7 & 14.5 & - & 72 & 1100\end{array}$


Table 31. Water-quality data for long-term streamwater sites, 1989-91--Continued

\begin{tabular}{|c|c|c|c|c|c|c|}
\hline Date & $\begin{array}{l}\text { Alumi- } \\
\text { num, } \\
\text { total } \\
\text { recov- } \\
\text { erable } \\
\text { ( } \mu \text { gll } \\
\text { as Al) }\end{array}$ & $\begin{array}{l}\text { Alumi- } \\
\text { num, } \\
\text { dis- } \\
\text { solved } \\
\text { ( } \mu \mathrm{g} / \\
\text { as Al) }\end{array}$ & $\begin{array}{l}\text { Iron, } \\
\text { total } \\
\text { recov- } \\
\text { erable } \\
\text { ( } \mu \mathrm{g} / \mathrm{L} \\
\text { as Fe) }\end{array}$ & $\begin{array}{l}\text { Iron, } \\
\text { dis- } \\
\text { solved } \\
\text { ( } \mu \text { gll } \\
\text { as Fe) }\end{array}$ & $\begin{array}{c}\text { Manga- } \\
\text { nese, } \\
\text { total } \\
\text { recov- } \\
\text { erable } \\
\text { ( } \mu g / 2 \\
\text { as } M n \text { ) }\end{array}$ & $\begin{array}{c}\text { Manga- } \\
\text { nese, } \\
\text { dls- } \\
\text { solved } \\
\text { ( } \mu \text { gl } \\
\text { as Mn) }\end{array}$ \\
\hline
\end{tabular}

395337082011100 O-1 MOXAHALA C NR DARLINGTON OH (LAT 3953 37N LONG 08201 11W)

$\begin{array}{lrrrrrr}\begin{array}{c}\text { AUG } 1989 \\ 15 \ldots\end{array} & 1400 & 90 & 1300 & 40 & 6800 & 6800 \\ \begin{array}{c}\text { OCT } \\ 17 \ldots\end{array} & 4200 & 450 & 2700 & 260 & 8200 & 7300 \\ \begin{array}{c}\text { SEPT } 1990 \\ \text { 05... }\end{array} & 630 & 100 & 280 & 40 & 7300 & 3000 \\ \begin{array}{c}\text { JUNE } 1991 \\ 11 \ldots\end{array} & 350 & 50 & 370 & 180 & 6000 & 5900 \\ \begin{array}{c}\text { AUG } \\ 27 \ldots\end{array} & 1800 & 190 & 190 & 90 & 6300 & 6700 \\ \begin{array}{c}\text { OCT } \\ 24 \ldots\end{array} & 7500 & 7100 & 440 & 270 & 11,000 & 11,000\end{array}$

03148400 O-2 MOXAHALA C AT ROBERTS OH (LAT 3951 17N LONG 08203 23W)

AUG 1989

$\begin{array}{lrrrrrr}\begin{array}{c}\text { AUG } 1989 \\ 15 \ldots\end{array} & 13,000 & 13,000 & 8900 & 7700 & 14,000 & 13,000 \\ \begin{array}{c}\text { OCT } \\ \begin{array}{l}17 \ldots \\ \text { SEPT } 1990\end{array}\end{array} & 7800 & 8100 & 4200 & 4500 & 9300 & 9000 \\ \begin{array}{c}\text { 05... } \\ \text { JUNE } 1991 \\ \quad 9600\end{array} & 9700 & 5200 & 4200 & 12,000 & 13,000 \\ \begin{array}{c}\text { AUG } \\ \quad 27 \ldots\end{array} & 8700 & 8800 & 3400 & 2900 & 9000 & 8500 \\ \begin{array}{c}\text { OCT } \\ 24 \ldots\end{array} & 11,000 & 11,000 & 3600 & 3700 & 12,000 & 14,000 \\ & 12,000 & 8300 & 8400 & 15,000 & 17,000\end{array}$

395214082054700 O-3 JONATHAN C AT WHITE COTTAGE OH (LAT 3952 14N LONG 08205 47W)

AUG 1989

$\begin{array}{ccccccc}\begin{array}{c}\text { AUG 1989 } \\ 14 \ldots\end{array} & 520 & 140 & 600 & 30 & 2700 & 2200 \\ \begin{array}{c}\text { OCT } \\ 18 \ldots\end{array} & 620 & 60 & 230 & 40 & 3100 & 3000 \\ \begin{array}{c}\text { SEPT } 1990 \\ \text { 05... }\end{array} & 320 & 120 & 250 & 20 & 3000 & 3000 \\ \begin{array}{c}\text { JUNE } 1991 \\ 12 \ldots\end{array} & 550 & 190 & 550 & 250 & 2500 & 2400 \\ \begin{array}{c}\text { AUG } \\ 27 \ldots\end{array} & 270 & 200 & 270 & 10 & 2200 & 2200 \\ \begin{array}{c}\text { OCT } \\ 24 \ldots\end{array} & 150 & 40 & 70 & 10 & 4900 & 4900\end{array}$


Table 31. Water-quality data for long-term streamwater sites, 1989-91--Continued

\begin{tabular}{|c|c|c|c|c|c|c|c|}
\hline Date & $\begin{array}{c}\text { Stream- } \\
\text { flow, } \\
\text { instan- } \\
\text { taneous } \\
\left(\mathrm{ft}^{3} / \mathrm{s}\right)\end{array}$ & $\begin{array}{c}\text { Spe- } \\
\text { ciflc } \\
\text { con- } \\
\text { duc- } \\
\text { tance } \\
(\mu S / c m)\end{array}$ & $\begin{array}{c}\text { pH } \\
\text { (stand- } \\
\text { ard } \\
\text { units) }\end{array}$ & $\begin{array}{l}\text { Temper- } \\
\text { ature, } \\
\text { water } \\
\left({ }^{\circ} \mathrm{C}\right)\end{array}$ & $\begin{array}{c}\text { Acidity } \\
\text { (mg/L } \\
\text { as } \\
\mathrm{CaCO}_{3} \text { ) }\end{array}$ & $\begin{array}{c}\text { Alka- } \\
\text { linity, } \\
\text { fieid } \\
\text { (mgll as } \\
\left.\mathrm{CaCO}_{3}\right)\end{array}$ & $\begin{array}{l}\text { Sulfate, } \\
\text { dis- } \\
\text { solved } \\
(\mathrm{mgh} \\
\left.\text { as } \mathrm{SO}_{4}\right)\end{array}$ \\
\hline
\end{tabular}

03156700 P-1 RUSH C NR SUGAR GROVE OH (LAT 3938 18N LONG $0823042 \mathrm{~W}$ )

$\begin{array}{cccccccc}\begin{array}{c}\text { AUG } 1989 \\ 14 \ldots\end{array} & 58 & 540 & 8.0 & 22.0 & -- & 107 & 140 \\ \begin{array}{c}\text { OCT } \\ 16 \ldots\end{array} & 63 & 555 & 7.3 & 15.5 & - & 91 & 150 \\ \begin{array}{c}\text { SEPT } 1990 \\ \text { 04.. }\end{array} & 33 & 825 & 7.6 & 24.0 & -- & 68 & 350 \\ \begin{array}{c}\text { JUNE } 1991 \\ \quad 10 \ldots\end{array} & 37 & 680 & 7.8 & 24.0 & -- & 97 & 180 \\ \begin{array}{c}\text { AUG } \\ 26 \ldots\end{array} & 14 & 599 & 7.6 & 24.5 & -- & 92 & 180 \\ \begin{array}{c}\text { OCT } \\ 25 \ldots\end{array} & 11 & 755 & 7.2 & 17.0 & - & 138 & 180\end{array}$

03157000 P-2 CLEAR C NR ROCKBRIDGE OH (LAT 3935 18N LONG 08234 43W)

AUG 1989

$\begin{array}{llllllll}\begin{array}{c}14 \ldots \\ \text { OCT }\end{array} & 37 & 445 & 8.6 & 21.0 & - & 201 & 37 \\ \begin{array}{l}16 \ldots \\ \text { SEPT } 1990\end{array} & 43 & 467 & 7.9 & 17.5 & -- & 194 & 42 \\ \begin{array}{l}\text { O4... } \\ \text { JUNE } 1991 \\ 10 \ldots\end{array} & 11 & 400 & 8.3 & 20.5 & -- & 180 & 26 \\ \begin{array}{c}\text { AUG } \\ 26 \ldots\end{array} & 27 & 440 & 8.4 & 19.5 & -- & 171 & 33 \\ \begin{array}{c}\text { OCT } \\ 25 \ldots\end{array} & 14 & 332 & 8.3 & 23.5 & -- & 153 & 20 \\ & 18 & 331 & 7.8 & 15.0 & - & 161 & 25\end{array}$

03158200 Q-1 MONDAY C AT DOANVILLE OH (LAT 392607 N LONG $0821130 \mathrm{~W}$ )

AUG 1989

\begin{tabular}{|c|c|c|c|c|c|c|c|}
\hline $\begin{array}{c}\text { AUG } 1989 \\
14 \ldots \\
\text { OCT }\end{array}$ & 49 & 960 & 3.7 & 19.0 & 70 & -- & 450 \\
\hline $\begin{array}{c}16 \ldots \\
\text { SEPT } 1990\end{array}$ & 41 & 809 & 4.6 & 15.5 & 36 & 1 & 350 \\
\hline $\begin{array}{c}05 . . \\
\text {. }\end{array}$ & 14 & 1300 & 3.4 & 20.5 & 134 & -- & 590 \\
\hline $\begin{array}{l}10 \ldots \\
\text { AUG }\end{array}$ & 19 & 1100 & 3.4 & 20.5 & 118 & -- & 620 \\
\hline OCT $^{27 \ldots}$ & 10 & 1900 & 3.7 & 24.0 & 78 & -- & 360 \\
\hline $23 \ldots$ & 4.9 & 1350 & 3.3 & 9.5 & 143 & -- & 560 \\
\hline
\end{tabular}


Table 31. Water-quality data for long-term streamwater sites, 1989-91--Continued

\begin{tabular}{|c|c|c|c|c|c|c|}
\hline Date & $\begin{array}{l}\text { Aluml- } \\
\text { num, } \\
\text { total } \\
\text { recov- } \\
\text { erable } \\
\text { ( } \mu \text { gll } \\
\text { as Al) }\end{array}$ & $\begin{array}{l}\text { Alumi- } \\
\text { num, } \\
\text { dis- } \\
\text { solved } \\
\text { ( } \mu g / 1 \\
\text { as Al) }\end{array}$ & $\begin{array}{l}\text { Iron, } \\
\text { total } \\
\text { recov- } \\
\text { erable } \\
\text { ( } \mu \mathrm{g} / \mathrm{L} \\
\text { es Fe) }\end{array}$ & $\begin{array}{l}\text { Iron, } \\
\text { dis- } \\
\text { solved } \\
\text { ( } \mu \text { gh } \\
\text { as Fe) }\end{array}$ & $\begin{array}{c}\text { Manga- } \\
\text { nese, } \\
\text { total } \\
\text { recov- } \\
\text { erable } \\
\text { ( } \mu \text { g/L } \\
\text { as Mn) }\end{array}$ & $\begin{array}{l}\text { Manga- } \\
\text { nese, } \\
\text { dls- } \\
\text { solved } \\
\text { ( } \mu \mathrm{g} / \mathrm{L} \\
\text { as Mn) }\end{array}$ \\
\hline
\end{tabular}

03156700 P-1 RUSH C NR SUGAR GROVE OH (LAT 3938 18N LONG 08230 42W)

AUG 1989

$\begin{array}{ccccccc}\begin{array}{c}\text { AUG } 1989 \\ \text { I4... }\end{array} & 350 & 40 & 840 & 20 & 880 & 860 \\ \begin{array}{c}\text { OCT } 16 \ldots \\ \text { SEPT } 1990 \\ 04 \ldots\end{array} & 420 & 30 & 590 & 10 & 1300 & 1300 \\ \begin{array}{c}\text { JUNE } 1991 \\ 10 \ldots\end{array} & 160 & 50 & 470 & 20 & 2500 & 2500 \\ \begin{array}{c}\text { AUG } \\ 26 \ldots\end{array} & 230 & 50 & 700 & 110 & 410 & 360 \\ \begin{array}{c}\text { OCT } \\ 25 \ldots\end{array} & 120 & 10 & 320 & 160 & 390 & 360\end{array}$

03157000 P-2 CLEAR C NR ROCKBRIDGE OH (LAT 3935 18N LONG 08234 43W)

AUG 1989

$\begin{array}{llccccc}\begin{array}{c}\text { AUG } 1989 \\ 14 \ldots\end{array} & 110 & 20 & 310 & 320 & 50 & 60 \\ \begin{array}{c}\text { OCT } \\ 16 \ldots\end{array} & 330 & 20 & 240 & 40 & 40 & 40 \\ \begin{array}{c}\text { SEPT } 1990 \\ \text { 04... }\end{array} & 120 & 30 & 330 & 40 & 30 & 40 \\ \begin{array}{c}\text { JUNE } 1991 \\ 10 \ldots\end{array} & 290 & 30 & 540 & 50 & 60 & 30 \\ \begin{array}{c}\text { AUG } \\ 26 \ldots\end{array} & 240 & <10 & 400 & 20 & 50 & 30 \\ \begin{array}{c}\text { OCT } \\ 25 \ldots\end{array} & 130 & <10 & 240 & 130 & 90 & 60\end{array}$

03158200 Q-1 MONDAY C AT DOANVILLE OH (LAT 3926 07N LONG $0821130 \mathrm{~W}$ )

AUG 1989

$\begin{array}{crrrrrr}\begin{array}{c}14 \ldots \\ \text { OCT }\end{array} & 12,000 & 10,000 & 6500 & 1100 & 4100 & 3600 \\ \begin{array}{c}16 \ldots \\ \text { SEPT } 1990 \\ \quad 45 \ldots\end{array} & 4300 & 2400 & 1500 & 420 & 2900 & 3100 \\ \begin{array}{c}\text { JUNE } 1991 \\ 10 \ldots\end{array} & 13,000 & 15,000 & 3400 & 3200 & 4500 & 4600 \\ \begin{array}{c}\text { AUG } \\ 27 \ldots\end{array} & 9200 & 9200 & 1800 & 1800 & 2600 & 3100 \\ \begin{array}{c}\text { OCT } \\ 23 \ldots\end{array} & 16,000 & 17,000 & 4700 & 5000 & 4300 & 4200\end{array}$


Table 31. Water-quality data for long-term streamwater sites, 1989-91--Continued

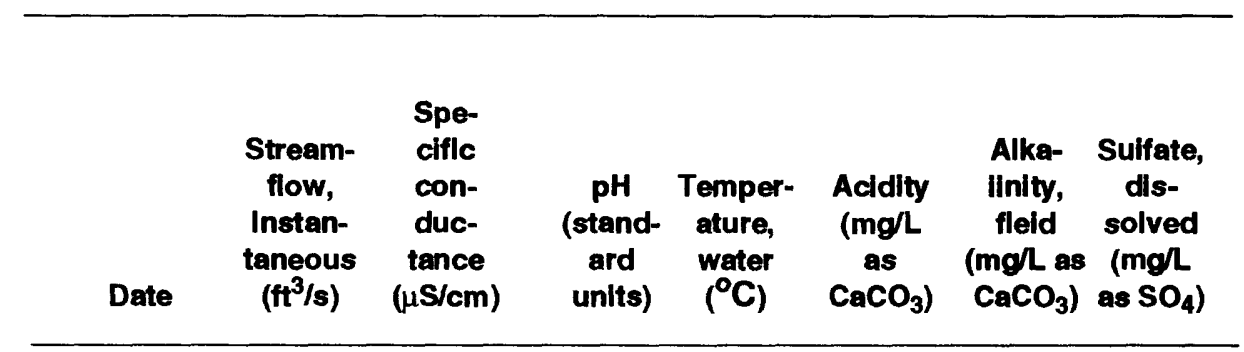

392342082072000 Q-2 SUNDAY C AT CHAUNCEY OH (LAT 3923 42N LONG 08207 20W)

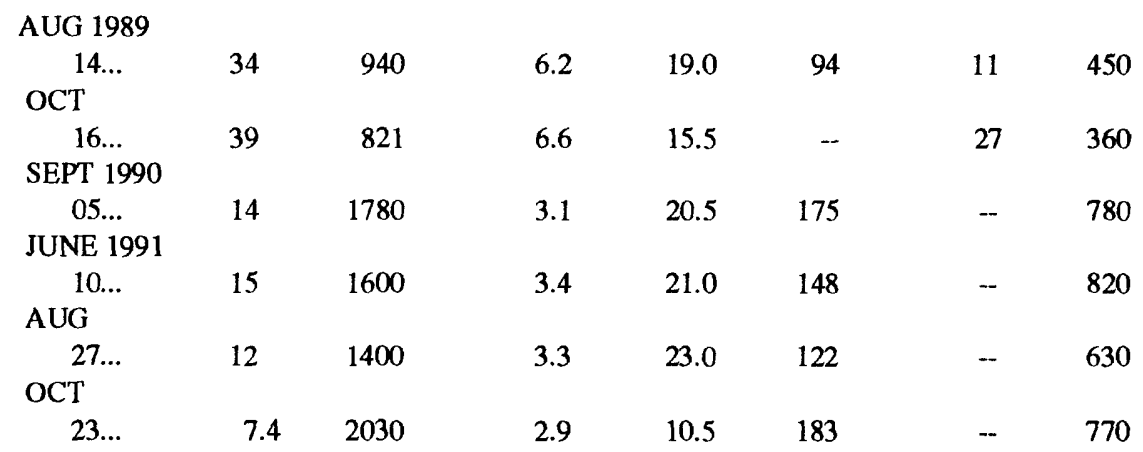

03160050 QQ-1 LEADING C NR MIDDLEPORT OH (LAT 390031 N LONG 08205 07W)

\begin{tabular}{|c|c|c|c|c|c|c|c|}
\hline $\begin{array}{c}\text { AUG } 1989 \\
16 \ldots\end{array}$ & 57 & 325 & 7.4 & 20.5 & -- & 34 & 91 \\
\hline DEC & & & & & & & \\
\hline $\begin{array}{c}04 \ldots \\
\text { AUG } 1990\end{array}$ & 45 & 1250 & 7.7 & .5 & -- & 75 & 320 \\
\hline $\begin{array}{c}31 \ldots \\
\text { JUNE } 1991\end{array}$ & 7.5 & 1600 & 7.7 & 23.5 & -- & 88 & 490 \\
\hline $\begin{array}{c}13 \ldots \\
\text { AUG }\end{array}$ & 2.4 & 1410 & 7.7 & 19.5 & -- & 112 & 390 \\
\hline OCT & 2.8 & 3100 & 7.2 & 22.5 & -- & 77 & 1100 \\
\hline $24 \ldots$ & 2.0 & 5170 & 7.4 & 16.5 & -- & 105 & 2100 \\
\hline
\end{tabular}

385826082201800 R-1 RACCOON C AT VINTON OH (LAT 3858 26N LONG $0822018 \mathrm{~W}$ )

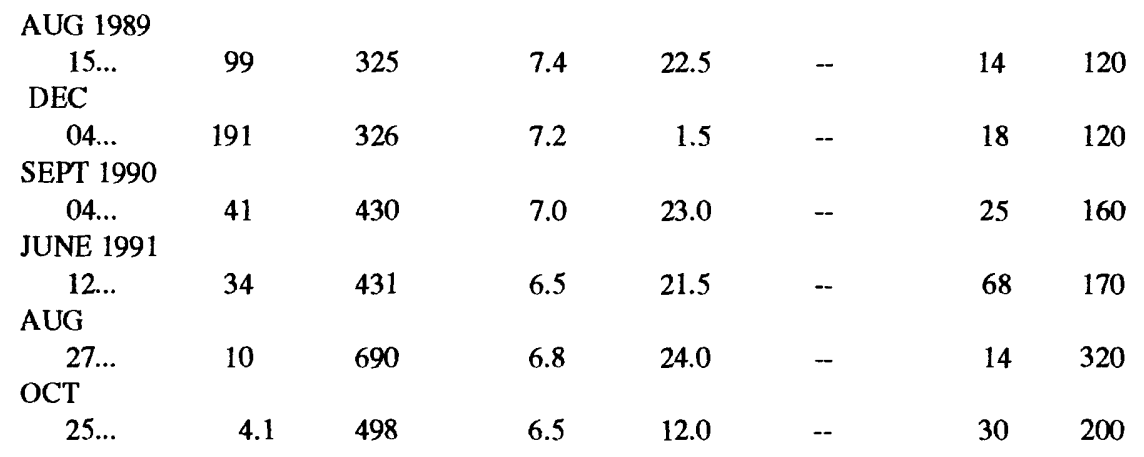


Table 31. Water-quality data for long-term streamwater sites, 1989-91--Continued

\begin{tabular}{|c|c|c|c|c|c|c|}
\hline Date & $\begin{array}{l}\text { Alumi- } \\
\text { num, } \\
\text { total } \\
\text { recov- } \\
\text { erabie } \\
\text { ( } \mu \mathrm{g} / \mathrm{L} \\
\text { as Al) }\end{array}$ & $\begin{array}{l}\text { Alumi- } \\
\text { num, } \\
\text { dls- } \\
\text { soived } \\
\text { ( } \mu g / 1 \\
\text { as Al) }\end{array}$ & $\begin{array}{l}\text { Iron, } \\
\text { total } \\
\text { recov- } \\
\text { erabie } \\
\text { ( } \mu g / L \\
\text { as Fe) }\end{array}$ & $\begin{array}{l}\text { Iron, } \\
\text { dls- } \\
\text { soived } \\
(\mu g / L \\
\text { as Fe) }\end{array}$ & $\begin{array}{c}\text { Manga- } \\
\text { nese, } \\
\text { total } \\
\text { recov- } \\
\text { erable } \\
\text { ( } \mu g / L \\
\text { as } M n)\end{array}$ & $\begin{array}{c}\text { Manga- } \\
\text { nese, } \\
\text { dls- } \\
\text { soived } \\
\text { ( } \mu \text { g/l } \\
\text { as Mn) }\end{array}$ \\
\hline
\end{tabular}

392342082072000 Q-2 SUNDAY C AT CHAUNCEY OH (LAT 3923 42N LONG 08207 20W)

$\begin{array}{lrrrrrr}\begin{array}{c}\text { AUG } 1989 \\ 14 \ldots\end{array} & 230 & 40 & 38,000 & 34,000 & 2200 & 2000 \\ \begin{array}{c}\text { OCT } \\ 16 \ldots\end{array} & <10 & 30 & 24,000 & 21,000 & 1500 & 1300 \\ \begin{array}{c}\text { SEPT } 1990 \\ \text { 05... }\end{array} & 1800 & 2000 & 44,000 & 41,000 & 3300 & 3400 \\ \begin{array}{c}\text { JUNE } 1991 \\ 10 \ldots\end{array} & 720 & 670 & 54,000 & 49,000 & 2800 & 2800 \\ \begin{array}{c}\text { AUG } \\ 27 \ldots\end{array} & 660 & 660 & 29,000 & 28,000 & 2100 & 2200 \\ \begin{array}{c}\text { OCT } \\ 23 \ldots\end{array} & 1800 & 1800 & 48,000 & 53,000 & 3500 & 3700\end{array}$

03160050 QQ-1 LEADING C NR MIDDLEPORT OH (LAT 390031 N LONG 08205 07W)

$\begin{array}{ccccccr}\begin{array}{c}\text { AUG } 1989 \\ 16 \ldots\end{array} & 8800 & 70 & 18,000 & 70 & 600 & 50 \\ \begin{array}{c}\text { DEC } \\ \text { 04... }\end{array} & 360 & 30 & 580 & 40 & 630 & 550 \\ \begin{array}{c}\text { AUG } 1990 \\ \quad 31 \ldots\end{array} & 100 & 40 & 350 & 90 & 220 & 210 \\ \begin{array}{c}\text { JUNE } 1991 \\ 13 \ldots\end{array} & 90 & 30 & 150 & 90 & 410 & 420 \\ \begin{array}{c}\text { AUG } \\ 27 \ldots\end{array} & 60 & 20 & 190 & 100 & 950 & 930 \\ \begin{array}{c}\text { OCT } \\ 24 \ldots\end{array} & 230 & 20 & 230 & 140 & 2400 & 2500\end{array}$

385826082201800 R-1 RACCOON C AT VINTON OH (LAT 3858 26N LONG $0822018 \mathrm{~W}$ )

$\begin{array}{lllllll}\begin{array}{c}\text { AUG } 1989 \\ 15 \ldots\end{array} & 230 & 10 & 930 & 10 & 1600 & 1400 \\ \begin{array}{c}\text { DEC } \\ \text { 04... }\end{array} & 50 & 10 & 590 & 420 & 2000 & 1800 \\ \begin{array}{c}\text { SEPT } 1990 \\ \text { 04... }\end{array} & 120 & 10 & 680 & 110 & 950 & 960 \\ \begin{array}{c}\text { JUNE } 1991 \\ 12 \ldots\end{array} & 120 & 10 & 470 & 70 & 2300 & 2400 \\ \begin{array}{c}\text { AUG } \\ 27 \ldots\end{array} & 100 & 10 & 360 & 110 & 780 & 760 \\ \begin{array}{c}\text { OCT } \\ 25 \ldots\end{array} & 110 & 20 & 720 & 310 & 630 & 630\end{array}$


Table 31. Water-quality data for long-term streamwater sites, 1989-91--Continued

\begin{tabular}{|c|c|c|c|c|c|c|c|}
\hline Date & $\begin{array}{c}\text { Stream- } \\
\text { flow, } \\
\text { Instan- } \\
\text { taneous } \\
\left(\mathrm{ft}^{3} / \mathrm{s}\right)\end{array}$ & $\begin{array}{c}\text { Spe- } \\
\text { cific } \\
\text { con- } \\
\text { duc- } \\
\text { tance } \\
(\mu S / \mathrm{cm})\end{array}$ & $\begin{array}{c}\text { pH } \\
\text { (stand- } \\
\text { ard } \\
\text { units) }\end{array}$ & $\begin{array}{c}\text { Temper- } \\
\text { ature, } \\
\text { water } \\
\left({ }^{\circ} \mathrm{C}\right)\end{array}$ & $\begin{array}{c}\text { Acidlty } \\
\text { (mg/L } \\
\text { as } \\
\mathrm{CaCO}_{3} \text { ) }\end{array}$ & $\begin{array}{c}\text { Alka- } \\
\text { linity, } \\
\text { fieid } \\
\text { (mgle as } \\
\left.\mathrm{CaCO}_{3}\right)\end{array}$ & $\begin{array}{c}\text { Sulfate, } \\
\text { dis- } \\
\text { solved } \\
\text { (mg/L } \\
\left.\text { as } \mathrm{SO}_{4}\right)\end{array}$ \\
\hline
\end{tabular}

390941082212200 R-2 ELK F NR RADCLIFF OH (LAT 3909 41N LONG 08221 22W)

\begin{tabular}{|c|c|c|c|c|c|c|}
\hline $\begin{array}{c}\text { AUG } 1989 \\
14 \ldots \\
\text { OCT }\end{array}$ & 4.3 & 375 & 7.8 & 21.0 & -- & 43 \\
\hline $\begin{array}{c}16 \ldots \\
\text { SEPT } 1990\end{array}$ & 14 & 377 & 7.0 & 16.0 & -- & 26 \\
\hline $\begin{array}{c}04 \ldots \\
\text { JUNE } 1991\end{array}$ & 6.7 & 345 & 7.1 & 21.0 & -. & 47 \\
\hline AUG $^{12 \ldots .}$ & 2.4 & 439 & 7.0 & 19.5 & -- & 43 \\
\hline $\mathrm{OCT}^{26 \ldots}$ & 1.0 & 559 & 7.1 & 24.0 & - & 43 \\
\hline $25 \ldots$ & .64 & 630 & 6.6 & 13.0 & -- & 66 \\
\hline
\end{tabular}

03201988 S-1 L RACCOON C NR VINTON OH (LAT 3857 11N LONG 08221 56W)

AUG 1989

\begin{tabular}{|c|c|c|c|c|c|c|}
\hline $\begin{array}{c}15 \ldots \\
\text { DEC }\end{array}$ & 13 & 545 & 7.2 & 22.5 & .. & 36 \\
\hline $04 \ldots$ & 76 & 410 & 6.9 & 1.5 & -- & 15 \\
\hline SEPT 1990 & & & & & & \\
\hline $\begin{array}{c}04 \ldots \\
\text { JUNE } 1991\end{array}$ & 28 & 425 & 7.0 & 22.5 & -- & 23 \\
\hline AUG & 13 & 569 & 7.0 & 21.0 & -- & 245 \\
\hline OCT & 9.1 & 620 & 6.7 & 23.5 & - & 10 \\
\hline $25 \ldots$ & 8.6 & 662 & 6.0 & 12.5 & 9.0 & 13 \\
\hline
\end{tabular}

03160105 S-2 CAMPAIGN C NR GALLIPOLIS OH (LAT 3853 51N LONG $0821131 \mathrm{~W}$ )

\begin{tabular}{|c|c|c|c|c|c|c|c|}
\hline AUG 1989 & & & & & & & \\
\hline $16 \ldots$ & .28 & 905 & 7.3 & 23.0 & - & 65 & 390 \\
\hline $\begin{array}{c}05 \ldots \\
\text { AUG } 1990\end{array}$ & 11 & 485 & 7.6 & 1.0 & -- & 66 & 170 \\
\hline $\begin{array}{c}\text { 31... } \\
\text { JUNE } 1991\end{array}$ & .62 & 540 & 7.7 & 27.0 & -- & 88 & \\
\hline $\begin{array}{l}12 \ldots . . \\
\text { AUG }\end{array}$ & .21 & 648 & 7.4 & 26.0 & - & 85 & \\
\hline $\mathrm{OCT}^{27 \ldots}$ & .07 & 720 & 7.1 & 29.0 & - & 46 & \\
\hline $24 \ldots$ & .17 & 830 & 7.1 & 19.5 & -- & 57 & 35 \\
\hline
\end{tabular}


Table 31. Water-quality data for long-term streamwater sites, 1989-91--Continued

\begin{tabular}{|c|c|c|c|c|c|c|}
\hline & $\begin{array}{l}\text { Alumi- } \\
\text { num, } \\
\text { total } \\
\text { recov- } \\
\text { erable } \\
\text { ( } \mu \mathrm{g} \text { 'L } \\
\text { as Al) }\end{array}$ & $\begin{array}{l}\text { Aluml- } \\
\text { num, } \\
\text { dis- } \\
\text { solved } \\
\text { ( } \mu g h \\
\text { as Al) }\end{array}$ & $\begin{array}{l}\text { Iron, } \\
\text { total } \\
\text { recov- } \\
\text { erable } \\
\text { ( } \mu g^{\prime} / \\
\text { as } \mathrm{Fe})\end{array}$ & $\begin{array}{c}\text { Iron, } \\
\text { dls- } \\
\text { solved } \\
\text { ( } \mu \mathrm{g} / \mathrm{L} \\
\text { as Fe) }\end{array}$ & $\begin{array}{l}\text { Manga- } \\
\text { nese, } \\
\text { total } \\
\text { recov- } \\
\text { erable } \\
\text { ( } \mu g / \mathrm{l} \\
\text { as Mn) }\end{array}$ & $\begin{array}{l}\text { Manga- } \\
\text { nese, } \\
\text { dls- } \\
\text { solved } \\
(\mu g / L \\
\text { as Mn) }\end{array}$ \\
\hline
\end{tabular}

390941082212200 R-2 ELK F NR RADCLIFF OH (LAT 3909 41N LONG 08221 22W)

$\begin{array}{ccccccc}\begin{array}{c}\text { AUG } 1989 \\ 14 \ldots\end{array} & 170 & 20 & 1400 & 60 & 870 & 870 \\ \begin{array}{c}\text { OCT } \\ 16 \ldots\end{array} & 30 & 30 & 450 & 170 & 560 & 630 \\ \begin{array}{c}\text { SEPT 1990 } \\ \quad 04 \ldots\end{array} & 50 & 20 & 860 & 160 & 430 & 430 \\ \begin{array}{c}\text { JUNE } 1991 \\ 12 \ldots\end{array} & 120 & 20 & 810 & 130 & 720 & 780 \\ \begin{array}{c}\text { AUG } \\ 26 \ldots\end{array} & 80 & 10 & 450 & 170 & 370 & 370 \\ \begin{array}{c}\text { OCT } \\ 25 \ldots\end{array} & 90 & 30 & 840 & 740 & 2400 & 2600\end{array}$

03201988 S-1 L RACCOON C NR VINTON OH (LAT 3857 11N LONG 08221 56W)

$\begin{array}{lrrrrrr}\begin{array}{c}\text { AUG } 1989 \\ 15 \ldots\end{array} & 60 & 20 & 420 & 50 & 2500 & 2500 \\ \begin{array}{c}\text { DEC } \\ \quad 04 \ldots\end{array} & 1200 & 30 & 4000 & 2200 & 2700 & 2300 \\ \begin{array}{c}\text { SEPT } 1990 \\ \quad 04 \ldots\end{array} & 50 & 30 & 490 & 70 & 2200 & 2200 \\ \begin{array}{c}\text { JUNE } 1991 \\ \quad 12 \ldots\end{array} & 70 & 10 & 520 & 210 & 2100 & 2100 \\ \begin{array}{c}\text { AUG } \\ 27 \ldots\end{array} & 90 & 10 & 250 & 40 & 2000 & 2100 \\ \begin{array}{c}\text { OCT } \\ 25 \ldots\end{array} & 970 & 80 & 2500 & 180 & 3100 & 3000\end{array}$

03160105 S-2 CAMPAIGN C NR GALLIPOLIS OH (LAT 3853 51N LONG $0821131 \mathrm{~W}$ )

$\begin{array}{ccccccc}\begin{array}{c}\text { AUG } 1989 \\ 16 \ldots\end{array} & 150 & 20 & 740 & <10 & 2900 & 2900 \\ \begin{array}{c}\text { DEC } \\ 05 \ldots\end{array} & 320 & 20 & 470 & 150 & 3000 & 2800 \\ \begin{array}{c}\text { AUG } 1990 \\ \quad 31 \ldots\end{array} & 160 & 20 & 750 & 40 & 850 & 800 \\ \begin{array}{c}\text { JUNE } 1991 \\ \quad 12 \ldots\end{array} & 500 & 20 & 1100 & 150 & 1300 & 840 \\ \text { AUG } & & & & & \\ \quad 27 \ldots & 190 & <10 & 420 & <10 & 2000 & 1900 \\ \begin{array}{c}\text { OCT } \\ 24 \ldots\end{array} & 240 & <10 & 730 & 50 & 790 & 720\end{array}$


Table 31. Water-quality data for long-term streamwater sites, 1989-91--Continued

\begin{tabular}{|c|c|c|c|c|c|c|c|}
\hline Date & $\begin{array}{l}\text { Stream- } \\
\text { flow, } \\
\text { Instan- } \\
\text { taneous } \\
\left(\mathrm{ft}^{3} / \mathrm{s}\right)\end{array}$ & $\begin{array}{l}\text { Spe- } \\
\text { clfic } \\
\text { con- } \\
\text { duc- } \\
\text { tance } \\
(\mu S / c m)\end{array}$ & $\begin{array}{c}\text { pH } \\
\text { (stand- } \\
\text { ard } \\
\text { unlts) }\end{array}$ & $\begin{array}{c}\text { Temper- } \\
\text { ature, } \\
\text { water } \\
\left({ }^{\circ} \mathrm{C}\right)\end{array}$ & $\begin{array}{c}\text { Acidity } \\
\text { (mg/L } \\
\text { as } \\
\mathrm{CaCO}_{3} \text { ) }\end{array}$ & $\begin{array}{c}\text { Alka- } \\
\text { linity, } \\
\text { fleid } \\
(\mathrm{mgl} \text { as } \\
\left.\mathrm{CaCO}_{3}\right)\end{array}$ & $\begin{array}{c}\text { Sulfate, } \\
\text { dis- } \\
\text { soived } \\
\text { (mg/L } \\
\text { as } \mathrm{SO}_{4} \text { ) }\end{array}$ \\
\hline
\end{tabular}

383005082280600 T-1 SYMMES C NR GETAWAY OH (LAT 3830 05N LONG 08228 06W)

$\begin{array}{cccccccc}\text { AUG } 1989 & & & & & & \\ \quad 15 \ldots & 16 & 445 & 7.6 & 22.5 & - & 65 & 110 \\ \begin{array}{c}\text { DEC } \\ \quad 05 \ldots\end{array} & 184 & 270 & 7.6 & 2.0 & - & 48 & 71 \\ \text { AUG } 1990 & & & & & & & \\ \quad 31 \ldots & 22 & 320 & 7.4 & 22.0 & - & 55 & 91 \\ \begin{array}{c}\text { JUNE } 1991 \\ \quad 13 \ldots\end{array} & 8.5 & 490 & 7.2 & 24.0 & - & 65 & 96 \\ \begin{array}{c}\text { AUG } \\ \quad 28 \ldots\end{array} & 12 & 320 & 7.2 & 24.5 & - & 52 & 72 \\ \text { OCT } & & & & & & & \\ 24 \ldots & 3.3 & 395 & 6.8 & 12.0 & -- & 66 & 110\end{array}$

382715082242400 T-2 INDIAN GUYAN C NR BRADRICK OH (LAT 3827 15N LONG 08224 24W)

\begin{tabular}{|c|c|c|c|c|c|c|c|}
\hline $\begin{array}{c}\text { AUG } 1989 \\
15 \ldots \\
\text { DFC }\end{array}$ & 3.5 & 450 & 8.1 & 22.5 & -- & 101 & 120 \\
\hline DEC & & & & & & & \\
\hline $\begin{array}{c}05 \ldots \\
\text { AUG } 1990\end{array}$ & 40 & 360 & 7.8 & 2.5 & - & 65 & 97 \\
\hline $\begin{array}{c}31 \ldots \\
\text { JUNE } 1991\end{array}$ & 3.8 & 520 & 7.9 & 23.0 & - & 94 & 170 \\
\hline $\begin{array}{l}13 \ldots \\
\text { AUG }\end{array}$ & 2.0 & 710 & 7.5 & 23.0 & -- & 75 & \\
\hline $\mathrm{OCT}^{28 \ldots}$ & .89 & 560 & 7.2 & 24.5 & -- & 86 & \\
\hline $24 \ldots$ & .70 & 713 & 7.0 & 14.5 & -- & 94 & 270 \\
\hline
\end{tabular}


Table 31. Water-quality data for long-term streamwater sites, 1989-91--Continued

\begin{tabular}{|c|c|c|c|c|c|c|}
\hline Date & $\begin{array}{l}\text { Alumi- } \\
\text { num, } \\
\text { totai } \\
\text { recov- } \\
\text { erable } \\
\text { ( } \mu \mathrm{g} / \mathrm{L} \\
\text { as } \mathrm{Al} \text { ) }\end{array}$ & $\begin{array}{l}\text { Aiuml- } \\
\text { num, } \\
\text { dls- } \\
\text { solved } \\
\text { ( } \mu \mathrm{gh} \\
\text { as Al) }\end{array}$ & $\begin{array}{l}\text { Iron, } \\
\text { total } \\
\text { recov- } \\
\text { erabie } \\
\text { ( } \mu g / L \\
\text { as Fe) }\end{array}$ & $\begin{array}{l}\text { Iron, } \\
\text { dis- } \\
\text { solved } \\
(\mu g / L \\
\text { as Fe) }\end{array}$ & $\begin{array}{c}\text { Manga- } \\
\text { nese, } \\
\text { total } \\
\text { recov- } \\
\text { erable } \\
\text { ( } \mu g / L \\
\text { as Mn) }\end{array}$ & $\begin{array}{l}\text { Manga- } \\
\text { nese, } \\
\text { dis- } \\
\text { soived } \\
\text { ( } \mu g / L \\
\text { as Mn) }\end{array}$ \\
\hline
\end{tabular}

383005082280600 T-1 SYMMES C NR GETAWAY OH (LAT 3830 05N LONG 08228 06W)

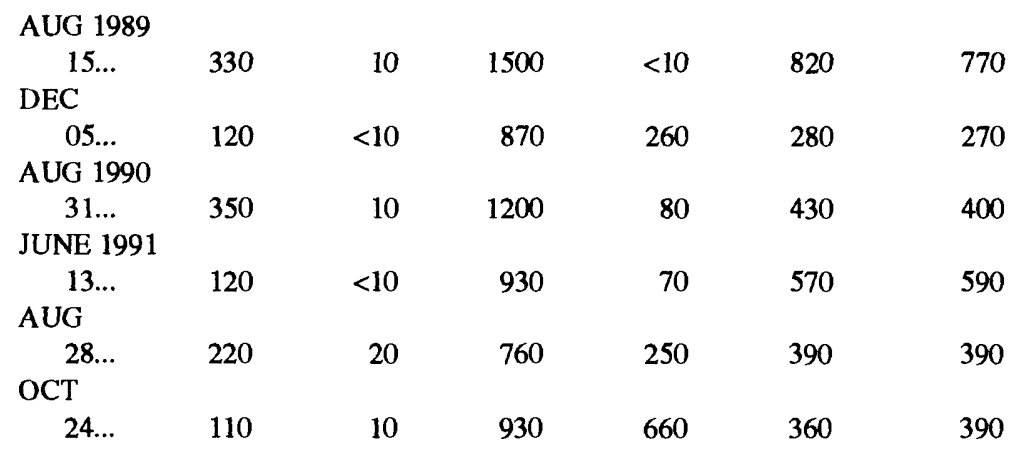

382715082242400 T-2 INDIAN GUYAN C NR BRADRICK OH (LAT 3827 15N LONG 08224 24W)

AUG 1989

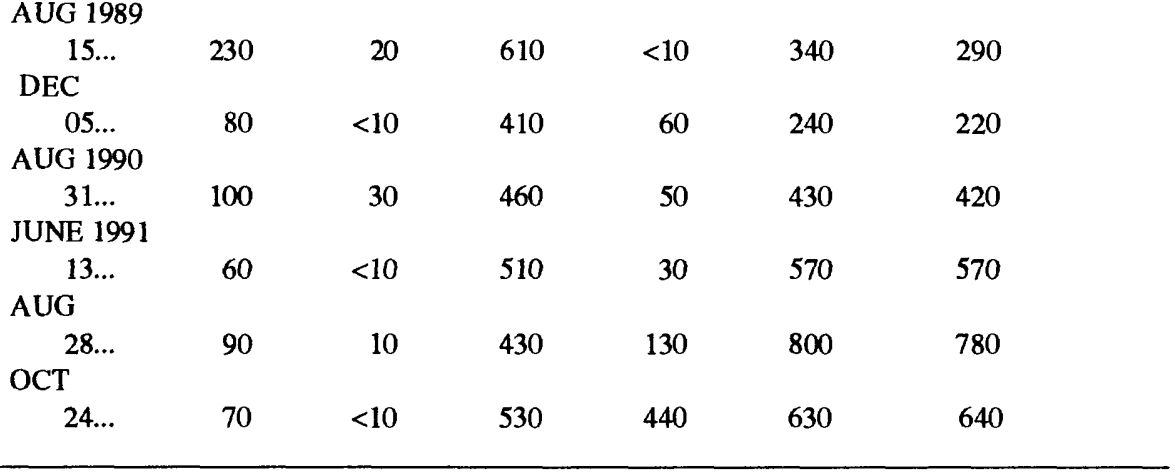


Addendum to "Geologic Setting and Water Quality of Selected Basins in the Active Coal Mining Areas of Ohio, 1989-91, with a Summary of Water Quality for 1985-91,"’ by Alan C. Sedam and Donna S. Francy (U.S. Geological Survey Water-Resources Investigations Report 93-4094)

1. Page 15, Line 27--"1991" should read "1989-91".

2. Page 49, Second paragraph--The sentence, "Streamwater sites B-1, B-4, and B-5 are in the Yellow Creek subbasin," should read "Streamwater sites B-1, B-4, B-5, and B-6 are in the Yellow Creek subbasin." Also, the sentence at the end of the paragraph, "Streamwater sites B-6, B-7, and B-8 are in the unnamed subbasin," should read "Streamwater sites B-7 and B-8 are in the unnamed subbasin."

3. Page 56 (map attached)--The short-term surface-water site J-7 near Holmesville was not indicated on the map in the report. 


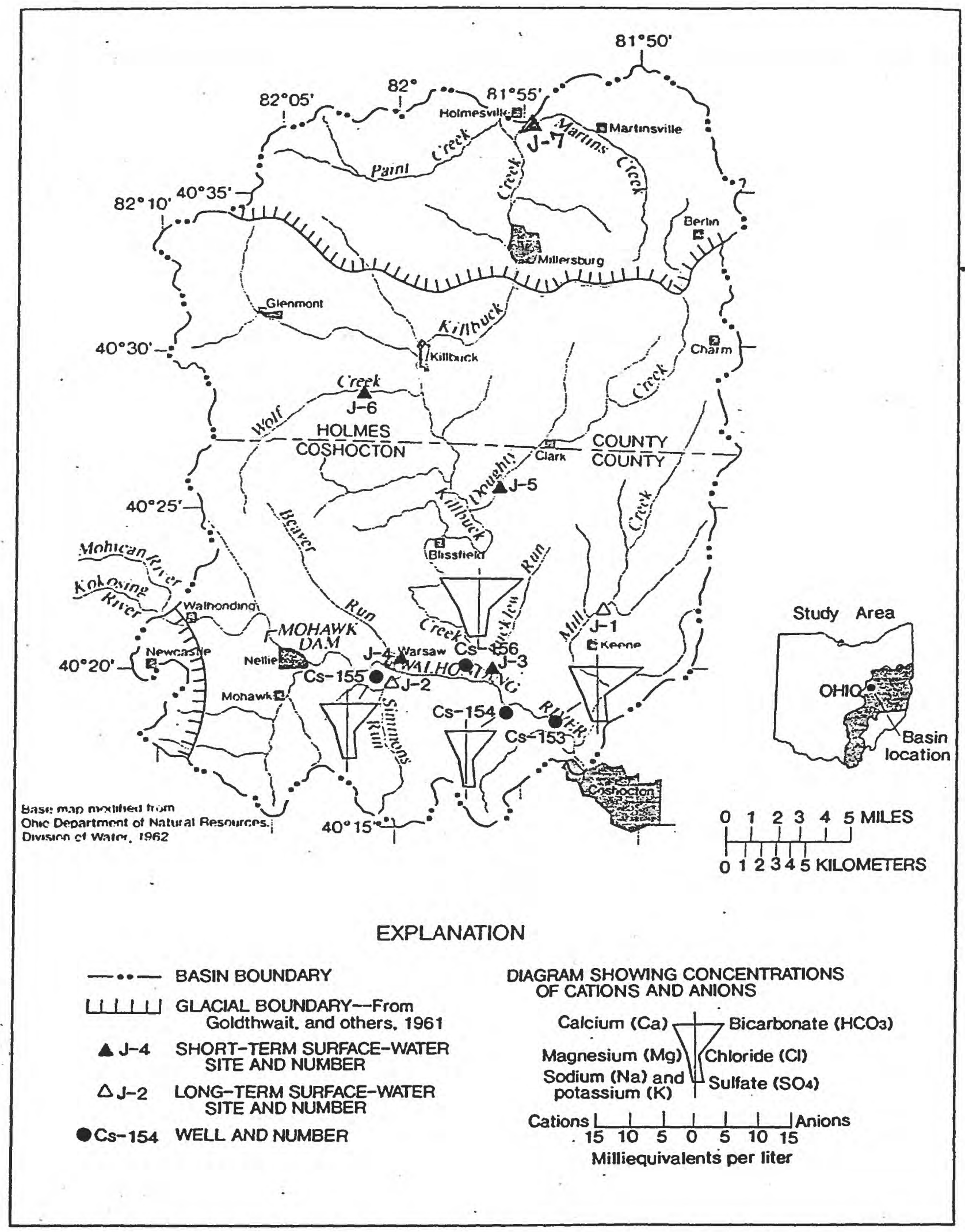

Figure 18.--Walhonding River basin (J). streamwater sites, ground-water sites, and Stiff diagrams for ground-water sites. 